A FEA e a USP respeitam os direitos autorais deste trabalho. Nós acreditamos que a melhor proteçào contra o uso ilegítimo deste texto é a publicação online. Além de preservar o conteúdo motiva-nos oferecer à sociedade o conhecimento produzido no âmbito da universidade pública e dar publicidade ao esforço do pesquisador. Entretanto, caso não seja do interesse do autor manter o documento online, pedimos compreensão em relação à iniciativa e o contato pelo e-mail bibfea@usp.br para que possamos tomar as providências cabiveis (remoção da tese ou dissertação da BDTD). 
UNIVERSIDADE DE SÃO PAULO

FACULDADE DE ECONOMIA, ADMINISTRAÇĀO E CONTABILIDADE DEPARTAMENTO DE CONTABILIDADE E ATUÁRIA

CONTRIBUIÇÃO À FORMULAÇÃO dE UM SISTEMA CONCEITUAL E OPERACIONAL CONTÁBIL de APURAÇĀO dE haVERES

EM PROCESSOS JUDICIAIS

MARTINHO MAURICIO GOMES DE ORNELAS

ORIENTADOR: PROF. DR. ELISEU MARTINS

Säo Paulo

2000 


\title{
REITOR DA UNIVERSIDADE DE SÃO PAULO
}

\author{
PROF. DR. JACQUES MARCOVITCH
}

DIRETOR

DA FACULDADE DE ECONOMIA, ADMINISTRAÇÃO E CONTABILIDADE

PROF. DR. ELISEU MARTINS

CHEFE DO DEPARTAMENTO DE CONTABILIDADE E ATUÁRIA

PROF. DR. REINALDO GUERREIRO 


\section{UNIVERSIDADE DE SÃO PAULO}

FACULDADE DE ECONOMIA, ADMINISTRAÇÃO E CONTABILIDADE DEPARTAMENTO DE CONTABILIDADE E ATUÁRIA

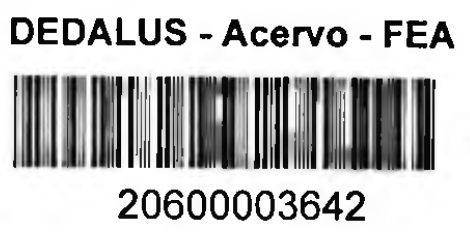

CONTRIBUIÇĀo À FORMULAÇÃO dE UM SISTEMA CONCEITUAL E OPERACIONAL CONTÁBIL de APURAÇÃo de haVERES

EM PROCESSOS JUDICIAIS

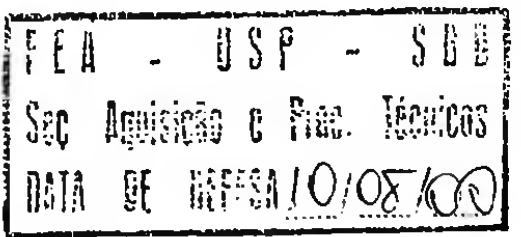

Tese apresentada à Faculdade de Economia, Administraçăo e Contabilidade para obtençăo do titulo de Doutor em Controladoria e Contabilidade.

ORIENTADOR: PROF. DR. ELISEU MARTINS

Sāo Paulo

2000 


\section{FICHA CATALOGRÁFICA}

Omelas, Martinho Mauricio Gomes de

Contribuiçà à formulação de um sistema conceitual contábil de apuração de haveres em processos judiciais / Martinho Mauricio Gomes de Ornelas. _ São Paulo : FEAUSP, 2000.

$232 \mathrm{p}$.

Tese - Doutorado

Bibliografia.

1. Empresas - Avaliação 2. Sociedades comerciais 3. Pericia contábil 1. Faculdade de Economia, Administração e Contabilidade da USP

$$
\text { CDD }-657.73
$$




\section{DEDICATÓRIA}

Dedico o presente trabalho:

A Iracy, mulher e esposa de todas as horas.

A Teo e a Laura, meus filhos, dos quais muito me orgulho.

A meus pais, Maria Laura e Manuel, que, embora ausentes

fisicamente, sempre iluminaram meus caminhos, nesta imensa terra. 


\section{AGRADECIMENTOS}

Várias são as pessoas a quem devo registrar meu respeito e gratidão.

Sem sombra de dúvida, com primazia, registro meu respeito e agradecimento ao Prof. Dr. Eliseu Martins, por ter aceito ser meu orientador, dedicando seu tempo e compartilhando seu saber comigo.

Nảo posso deixar de agradecer a todos os professores das disciplinas cursadas, com destaque para aqueles que, direta ou indiretamente, tiveram influência e contribuição no tema escolhido. Meus respeitos e agradecimentos aos Profs. Drs. Armando Catelli, Luiz João Corrar, Nilton Cano, Sérgio de ludícibus, Stephen Charles Kanitz.

Ao Prof. Dr. Fábio Ulhoa Coelho, eminente comercialista, pela oportunidade que me proporcionou de debater com ele a questão da apuração de haveres sob a óptica contábil.

A meu amigo e colega de turma, já agora Prof. Dr. Ivam Ricardo Peleias, pelo incentivo constante ao desenvolvimento deste trabalho.

Fora da academia, não posso deixar de registrar meus agradecimentos aos MM. Juizes Dr. James Alberto Siano e Dr. José Maria Simōes de Vergueiro; o primeiro pela contribuição ao liberar-me importantes dados estatísticos sobre processos de dissolução de sociedades do Foro Central da Capital de São Paulo; o segundo pelo incentivo ao presente trabalho e alegria com que sempre me brinda.

Devo também registrar agradecimentos a meus alunos da cadeira de Perícia Contábil, da Pontifícia Universidade Católica de São Paulo, que, ao apresentarem seus seminários sobre perícia contábil em apuração de haveres, sempre me apresentaram questōes técnicas desafiantes. 


\section{SUMÁRIO}

\section{LISTA DE FIGURAS}

RESUMO

ABSTRACT

INTRODUÇÃO 1

I Da contribuição pretendida 1

II Dos objetivos perseguidos $\quad 1$

III Dos pressupostos considerados 2

IV Das justificativas 3

V Da delimitação do tema 4

VI Da problematização do tema 5

VII Da hipótese considerada $\quad 6$

VIII Da metodologia adotada $\quad 7$

IX Definição de termos utilizados no trabalho 11

\section{CAPITULO 1}

AVALIAÇÃO DE SOCIEDADES NA CONTINUIDADE 13

$\begin{array}{ll}1.1 \text { A quem interessa } & 14\end{array}$

1.1.1 Avaliação para fins de alienação: venda ou compra 14

1.1.2 Avaliação para fins de fusāo, incorporação e cisão 16

1.1.3 Avaliação para fins de admissão de novos investidores 19

1.1.4 Avaliação para fins de captação de recursos de terceiros 19

1.1.5 Avaliação para fins de reembolso de capital 21

1.1.6 Avaliaçāo para fins judiciais 22

1.1.7 Encerramento de atividade: fechar ou continuar? 22

1.2 Avaliação de sociedades em marcha 23

$\begin{array}{ll}1.3 \text { Modelos avaliatórios } & 30\end{array}$

1.4 Métodos avaliatórios $\quad 34$ 


\section{CAPITULO 6}

\section{PRINCÍPIOS CONTÁBEIS E BALANÇO DE DETERMINAÇÃO}

6.1 Principios contábeis

6.2 Normas brasileiras de contabilidade

6.3 Avaliação patrimonial em processos judiciais

6.3.1 Avaliação dos itens monetários

6.3.2 Avaliação dos itens não monetários

6.3.3 Contingências

6.3.4 Goodwill

6.4 Balanço de determinação

\section{CAPITULO 7}

GOODWLL EM APURAÇĀO DE HAVERES: PROPOSIÇĀO

7.1 Algumas definiçōes

7.2 Classificação do goodwill

7.3 Aspectos polêmicos quanto à mensuraçăo do goodwill

7.4 Goodwill adquirido e não adquirido

7.5 Goodwill negativo ou badwill

7.6 Fórmulas de cálculo do goodwill

7.7 Proposição

7.7.2 Fórmulas propostas

7.7.3 Alguns comentários sobre a proposição

7.7.3 Testando o modelo

\section{CAPITULO 8}

\section{DIFICULDADES E LIMITES PERICIAIS}

8.1 Alguns aspectos operacionais periciais

8.2 Ausência das demonstraçōes especiais da data do evento

8.3 Inexistência de livros mercantis escriturados

\section{APÊNDICE}

Proposta de modelo de laudo pericial contábil e roteiro de

apuração de haveres 


\section{LISTA DE FIGURAS}

$\begin{array}{lll}\text { Figura } 1 \text { Balanço operacional } & 41\end{array}$

Figura 2 Balanço de liquidação 62

Figura 3 Balanço de determinação 135

Figura 4 Valor da sociedade inclusive goodwill, sem ajustes avaliatórios

Figura 5 Valor da sociedade inclusive goodwill, com ajustes avaliatórios no ativo permanente operacional $e$ contingências

Figura 6 Valor da sociedade inclusive goodwill, com ajustes avaliatórios no ativo circulante e permanente operacional e contingências

Figura 7 Valor da sociedade inclusive goodwill, com ajustes avaliatórios no ativo circulante e permanente operacional, ativo não operacional e contingências

Figura 8 Valor da sociedade inclusive goodwill, com ajustes avaliatórios no ativo circulante, permanente $e$ passivo operacional, ativo nāo operacional, passivo financeiro e contingências

Figura 9 Valor da sociedade inclusive goodwill, com ativo operacional líquido negativo e ajustes avaliatórios no ativo permanente operacional e contingências 


\section{RESUMO}

O presente trabalho trata da avaliação de sociedades em processos judiciais, nos quais é determinada a apuração de haveres realizada por expert em contabilidade.

Para introduzir o tema, é abordada preliminarmente a avaliação de sociedades na continuidade operacional, em suas várias possibilidades e interesses, assim como os modelos e métodos avaliatórios, seus limites e fatores influenciadores do processo avaliatório.

Alguns aspectos das teorias do valor, do risco, da taxa de juros e dos preços são tratados, já que tais temas são recorrentes no processo avaliatório, especialmente para marcar a diferença entre valor e preço, muitas vezes olvidada nos processos judiciais.

A avaliaçāo de sociedades em descontinuidade, voluntária ou involuntária, é enfrentada à luz do ordenamento jurídico nacional de dissolução judicial de sociedades e de seus reflexos contábeis, especialmente quanto aos procedimentos avaliatórios e de elaboração do balanço de liquidação.

As diretrizes emanadas da jurisprudência brasileira sobre apuraçăo de haveres, extraídas dos pronunciamentos dos Tribunais Superiores, são interpretadas sob a óptica contábil, e verificada sua aderência aos Principios e Normas Brasileiras de Contabilidade, que resultam em diretrizes contábeis de avaliaçăo de sociedades em processos judiciais e culminam na elaboração do balanço de determinação. 
Quanto ao goodwill não adquirido, tema inerente à avaliação de sociedades em processos judiciais, após a apresentação das várias vertentes doutrinárias juridicas e contábeis e das várias fórmulas de cálculo, são propostos caminhos compativeis com a avaliação judicial.

Por fim, são expostos limites e dificuldades com que se depara o expert contábil, especialmente os relativos à ausência de demonstraçōes contábeis especiais da data do evento e, ainda, quanto à inexistência de livros mercantis escriturados, sugerindo-se, quando viável, procedimentos periciais contábeis alternativos.

Em apêndice, é oferecida proposta de modelo de laudo pericial contábil e roteiro de apuração de haveres. 


\section{ABSTRACT}

This work deals with companies 'or firms' appraisals in judicial proceedings in which determined asset appraisals are made by an accounting expert.

Introducing the subject, it is discussed preliminarily the appraisal of companies 'or firms' in going concern with its many possibilities and interests, as well as the models and appraisal methods, their limits and influencing factors over the appraisal proceedings.

Some aspects of value, risk, interest rates and price theories are dealt with, once they are recurring aspects of the appraisal proceeding, in special to mark the difference between value and price, which is commonly forgotten in judicial proceedings.

The appraisal of companies 'or firms' in discontinuity, be it intentional or not, is treated in the light of the national legal system on companies 'or firms' judicial dissolution and its accounting effects, in special regarding the appraisal proceedings and the elaboration of the liquidation balance sheet.

The directives originated from Brazilian jurisprudence on assets appraisal, as extracted from decisions of the Superior Courts, are considered and interpreted from an accounting point of view, and their adherence to Brazilian Principles and Standards of Accounting, resulting in accounting directives for companies 'or firms' appraisal in judicial proceedings, and leading to the elaboration of the determination balance sheet, are verified. 


\section{INTRODUÇĀO}

Destacamos nesta introdução a contribuição pretendida, o objetivo do trabalho, os pressupostos assumidos, a estrutura metodológica considerada, a notícia da literatura relativa ao tema, o processo de organização do trabalho e, por fim, um glossário de alguns termos utilizados.

\section{DA CONTRIBUIÇÃO PRETENDIDA}

Apuração de haveres é tema contábil relevante no desenvolvimento de perícia contábil em processos judiciais de inventário e de dissolução de sociedades.

O magistrado, por força de dispositivos legais constantes do Código de Processo Civil, de ofício ou a requerimento, nomeia perito em contabilidade para oferecer avaliação das quotas de capital de sociedades contratuais organizadas sob a forma de limitadas, por meio de laudo pericial contábil que possibilita a partilha entre os herdeiros, no caso de inventário, do quantum relativo às quotas de sócio falecido; e ao sócio dissidente, excluído ou aos sócios de sociedade em liquidação, a partilha do quinhão patrimonial de cada um.

O tema, portanto, envolve a avaliação de acervos patrimoniais para fins específicos judiciais.

\section{DOS OBJETIVOS PERSEGUIDOS}

Este trabalho tem por escopo central formular um modelo conceitual e operacional contábil de apuração de haveres em processos judiciais, à luz dos 
principios e convenções contábeis, que permitam operacionalizar e compatibilizar a orientação emanada dos tribunais pátrios.

Esse objetivo central pode ser desdobrado em proposiçōes mais especificas, a saber:

- oferecer um quadro teórico contábil aplicável à avaliação, por determinação judicial, de sociedades contratuais;

- propor procedimentos, métodos e técnicas periciais contábeis aplicáveis em processos judiciais de dissolução parcial ou total de sociedades contratuais, em funcionamento ou em liquidação judicial, que envolvem apuração de haveres;

- propor procedimentos, métodos e técnicas de natureza pericial contábil que possam vir a suprir a lamentável ausência de registros contábeis nos micro e pequenos negócios, situação fática que muito afeta a apuração de haveres;

- propor modelo e roteiro de elaboração de laudo pericial contábil compativel com essa modalidade pericial.

Para atingir tais metas, é necessário identificar as aplicações da apuração de haveres nos vários tipos de processos judiciais nos quais é exigida ou determinada. Nesse sentido, socorremo-nos do arcabouço legal que disciplina a apuração de haveres.

\section{DOS PRESSUPOSTOS CONSIDERADOS}

Este trabalho considera um leque de pressupostos tratados em obras de Teoria da Avaliação Patrimonial e do Lucro, de Direito Comercial e de Direito de Familia e Sucessões.

Admitimos determinados pressupostos da doutrina contábil combinados com a doutrina jurídica, que se interpenetram e são, em alguns momentos, conflitantes. 
Os pressupostos fornecem as diretrizes com base nas quais o trabalho é desenvolvido.

Sociedades são dissolvidas, total ou parcialmente, em decorrência de dissidências societárias ou da morte de sócio, obedecendo-se ao ordenamento jurídico pátrio. A tendência predominante dos tribunais, como veremos mais adiante, é de decidir pela continuidade da sociedade, declarando-a dissolvida parcialmente e determinando a apuração de haveres em favor do sócio retirante ou dos herdeiros de sócio falecido, da forma mais ampla possível, de modo que seja apurado o valor do patrimônio a valores de mercado. Temos, normalmente, uma sociedade em marcha a ser avaliada, mas em descontinuidade em relação ao sócio retirante ou falecido.

Proceder à apuração de haveres significa buscar o montante do patrimônio líquido que cabe ao interessado em função da participação no capital social da sociedade. Mas qual é esse montante? Encontrar a resposta para essa indagação é a grande tarefa do perito em contabilidade nomeado em Juízo.

A resposta a essa indagação será naturalmente apoiada na doutrina contábil aplicável à espécie avaliatória patrimonial, em face dos pronunciamentos dos tribunais.

\section{DAS JUSTIFICATIVAS}

Algumas observaçōes pessoais advindas da vivência profissional no campo objeto deste trabalho têm evidenciado que os peritos em contabilidade vêm apresentando seus trabalhos periciais sem o necessário rigor técnico contábil, com eventuais prejuizos para os interessados na referida apuração, que, muitas vezes, olvidam as diretrizes emanadas dos tribunais pátrios.

$\dot{E}$ de serem ressaltados os diversos entendimentos técnicos quanto ao próprio processo avaliatório do acervo patrimonial, em especial quanto ao cálculo do goodwill, que no campo juridico assemelha-se ao denominado aviamento, 
equivocadamente denominado fundo de comércio, cujas fórmulas matemáticas mais usualmente aplicadas nos trabalhos judiciais vêm sofrendo severas restrições dos estudiosos.

\section{DA DELIMITAÇÃO DO TEMA}

Este trabalho situa-se em área limitrofe, em que se encontram a ciência contábil e a ciência juridica, em decorrência de processos judiciais que demandam apuração de haveres.

No campo da ciência contábil, inscreve-se na área da teoria da avaliação patrimonial e do lucro, que inclui a mensuração de ativos e passivos e a capacidade de determinado acervo patrimonial gerar resultados ao longo do tempo.

Sob essa óptica, devemos ter presente que os laudos periciais contábeis de apuração de haveres destinam-se a usuários muito específicos, o magistrado e os advogados das partes, os herdeiros e os sócios, que não têm nenhuma obrigação funcional de dominar o universo contábil, mas necessitam compreender o conteúdo das peças técnicas elaboradas pelos peritos em contabilidade; o magistrado, para sentenciar e homologar os valores apurados; os advogados, para defenderem com competência seus clientes; os herdeiros e sócios, para aquilatarem o montante de seus direitos.

Filosoficamente, levando em conta os vários enfoques aplicáveis à Contabilidade, podemos colocar o presente trabalho sob a Teoria da Comunicação, definida por IUDíCIBUS como "o método de identificar, mensurar e comunicar informação econômica, a fím de permitir decisões e julgamentos adequados por parte dos usuários da informação" à medida que o laudo pericial contábil de apuraçāo de haveres possui todas essas características.

Da ciência juridica importa considerar as diretrizes relativas ao disciplinamento legal concernente à dissolução parcial ou total de sociedades e à respectiva apuraçāo de haveres, começando pelo Código Comercial, Lei das

Sérgio de IUDíCIBUS, Teoria da contabilidade, p. 24. 
Sociedades por Quotas de Responsabilidade Limitada, Código de Processo Civil e, subsidiariamente, pela Lei das Sociedades por Açōes.

Cabe aqui um alerta; este não é um trabalho de cunho jurídico. Visamos, na verdade, colher elementos do saber jurídico que possibilitem a compreensāo do fenômeno estudado, ou seja, a apuração de haveres enquanto procedimento de avaliação de acervo patrimonial de determinada sociedade.

\section{DA PROBLEMATIZAÇÃO DO TEMA}

Os especialistas em metodologia cientifica afirmam que, para se levar a bom termo um trabalho de cunho cientifico, é premente e necessário problematizar os fatos sob investigação.

Relativamente à vertente do conhecimento contábil sobre a qual estamos debruçando-nos, desconhecemos trabalhos pátrios que proponham a formulação de um modelo conceitual e operacional de apuração de haveres em processos judiciais, compativel e adequado aos pronunciamentos dos tribunais. Assim, podemos propor como problema-alvo deste trabalho:

- Como estruturar um sistema de avaliação patrimonial que sirva de suporte ao processo decisório judicial que envolve apuração de haveres?

Daí decorrem outros questionamentos, a saber:

- Os acervos patrimoniais das sociedades, à luz dos pronunciamentos judiciais, devem ser avaliados, considerando que premissas? Ativos devem ser avaliados pela óptica da liquidação ou pela continuidade da sociedade?

- Quais as categorias de bens reconhecidas pela doutrina jurídica que são sujeitas a avaliação?

- Como enfrentar a dissolução parcial de sociedade decorrente de retirada de sócio à luz dos princípios fundamentais de contabilidade? Estes sāo aderentes aos pronunciamentos judiciais? 
- Quais as implicações de natureza tributária em face da reavaliação de bens e da mensuração do goodwill, itens normalmente considerados no processo avaliatório judicial?

Este trabalho busca oferecer respostas aos problemas apresentados.

\section{DA HIPÓTESE CONSIDERADA}

Assumimos que o processo de avaliação de sociedades para fins judiciais pode ser otimizado por instrumentos que auxiliem os peritos em contabilidade a mensurar corretamente acervos patrimoniais; para isso, é necessário identificar e formatar um modelo conceitual e operacional, compativel com os princípios fundamentais de contabilidade e com a jurisprudência pátria, que contribua para a eficácia avaliatória em processos judiciais de apuração de haveres.

A hipótese assumida não contradiz nenhuma verdade já aceita, salvo no que se refere ao comando jurisprudencial de que a apuração de haveres se processa como se dissolução societária total fosse; a necessidade de mensurar corretamente acervos patrimoniais é tema recorrente, estudado e aceito em trabalhos sobre teoria da avaliação patrimonial e do lucro; entretanto, tal necessidade é examinada sob vertente específica, qual seja, a avaliação patrimonial sob a égide judicial, a fim de não prejudicar os interessados nos processos judiciais.

É uma hipótese simples, verificável, aplicável e especifica; simples, porque seu enunciado condiz com o próprio entendimento do que perseguimos; verificável, por meio dos fatos identificados na pesquisa da jurisprudência levada a efeito; aplicável, à medida que são consideradas determinadas características necessárias a sua operacionalidade; e especifica, visto que dimensionamos o que pretendemos verificar.

Consideramos que existem referenciais empíricos para o teste de validação, sem julgamento de valor, e que a pesquisa empreendida é parcimoniosa e relaciona-se às técnicas de pesquisa cientifica, podendo ser testada empiricamente, 
além do que se insere no universo conceitual que suporta a teoria da avaliação patrimonial e do lucro.

\section{DA METODOLOGIA ADOTADA}

Da consulta ao catálogo de teses e dissertações produzidas no Brasil, no campo da ciência contábil, ficou evidenciada a inexistência de um trabalho pormenorizado na área da Teoria da Avaliação Patrimonial e do Lucro que abordasse o tema avaliação de sociedades em processos judiciais e a correspondente apuração de haveres.

Essa lacuna foi também corroborada após a consulta a diversas obras de contabilidade e de avaliação de sociedades, o que nos levou a aceitar o desafio de empreender o presente trabalho.

No que se refere ao tema de fundo, este trabalho apóia-se em pesquisa da jurisprudência brasileira relativa à apuração de haveres em processos judiciais de dissolução de sociedades. Preliminarmente, procedemos à coleta dos pronunciamentos dos principais tribunais pátrios, em especial do Egrégio Supremo Tribunal Federal e Supremo Tribunal de Justiça, que permitiram apreender a orientação emanada da jurisprudência predominante.

$\dot{E}$ de ser registrado que tentamos obter de profissionais que militam nas Varas Civeis do Foro Central da Capital de São Paulo laudos periciais contábeis de apuraçāo de haveres; todavia, a empreitada redundou em fracasso, pois obtivemos amostra estatisticamente insignificante para um universo de 695 processos de dissolução de sociedades distribuídos no período de 1993 a 1995 . Pretendiamos verificar a aderência desses trabalhos técnicos às diretrizes emanadas da jurisprudência. É um desafio futuro.

De posse de súmulas, acórdãos e ementas, procedemos à leitura e a seu ordenamento em função das diretrizes delas emanadas. 
$\mathrm{Na}$ construção de um quadro teórico contábil aplicável à apuração de haveres, desenvolvemos pesquisa bibliográfica, tendo por norte a Teoria da Avaliação Patrimonial e do Lucro, sob dois enfoques:

1. a avaliação patrimonial na continuidade dos negócios; e

2. a avaliação patrimonial na descontinuidade dos negócios.

Merecem destaque as obras de autores nacionais de renome, como, por exemplo, SÉRGIO DE IUDíCIBUS, com Teoria da contabilidade, ELISEU MARTINS, com sua tese de doutoramento Contribuição à avaliação do ativo intangível, e MASSANORI MONOBE, com a tese de doutoramento Contribuição à mensuração e contabilização do goodwill não adquirido.

Do cenário internacional, foram colhidos ensinamentos, entre outros, de ELDON S. HENDRIKSEN, em sua renomada obra Accounting theory, de JEAN ALLA, com L'évaluation de l'entreprise: de la théorie à la pratique; de COPELAND, KOLLER e MURRIN, com Valuation: measuring and managing the value of companies; de ASWATH DAMODARAN, com Avaliação de investimentos: ferramentas e técnicas para a determinação do valor de qualquer ativo.

A par disso, buscando sistematizar determinados elementos juridicos orientadores da dissoluçāo de sociedades e da apuraçāo de haveres que lhe é pertinente, foram compulsadas obras de renomados juristas. Foram colhidos ensinamentos, entre outros, de RUBENS REQUIÃO, da obra Curso de direito comercial; de FRAN MARTINS, da obra Curso de direito comercial; de WALDIRIO BULGARELLI, das obras Fusões, incorporações e cisões de sociedades e Sociedades comerciais; de ARNOLDO WALD, da obra Direito das sucessões; de FÁBIO ULHOA COELHO, da obra Curso de direito comercial; além das obras citadas, foi examinada uma obra polêmica, denominada Apuração dos haveres de sócio, de autoria de HERNANI ESTRELLA.

O presente trabalho, ordenado em oito capítulos, possibilita as abordagens e reflexões necessárias para responder à problematização proposta. Os capítulos, por sua vez, foram divididos em seções, que permitem o encadeamento lógico das idéias e dos pontos necessários ao enfrentamento do tema. 
As notas de rodapé e referências bibliográficas estāo numeradas seqüencialmente ao longo de cada um dos capitulos. Quando citados, os autores sāo explicitados por completo, a fim de evitar eventuais confusōes de sobrenomes iguais. Nesses aspectos, seguimos a orientaçăo de Antônio Joaquim Severino, contida na obra Metodologia do trabalho científico.

Contribuição à formulação de um sistema conceitual e operacional contábil de apuração de haveres em processos judiciais está organizada em oito capítulos, a saber:

\section{CAPITULO 1 - AVALIAÇĀO DE SOCIEDADES NA CONTINUIDADE}

Nesse capítulo, sāo abordadas as várias possibilidades avaliatórias de sociedades em continuidade de suas atividades, os modelos e métodos avaliatórios aplicáveis, bem como os limites e fatores que influenciam os procedimentos avaliatórios.

\section{CAPITTULO 2 - VALOR, VALOR ECONÔMICO, RISCO E TAXA DE JUROS}

Aqui, são tecidos comentários e abordadas as conceituaçōes de valor e valor econômico sob a óptica da ciência econômica. O risco, a incerteza e a taxa de juros, temas presentes no processo avaliatório, sāo desenvolvidos sob o enfoque da teoria dos portfólios.

\section{CAPITULO 3 - AVALIAÇÄO DE EMPRESAS NA DESCONTINUIDADE}

São abordadas duas alternativas de descontinuidade. A primeira, denominada voluntária, ocorre ao término do empreendimento, ou pela vontade coletiva de sócios ou acionistas, a qualquer momento. A segunda, involuntária, ocorre por decretação judicial, ou ainda, é originária da intervençāo estatal mediante desapropriação. Propomos modelo avaliatório e balanço de liquidação compativel com o ordenamento e doutrina juridica na descontinuidade.

\section{CAPITULO 4 - DISSOLUÇĀO JUDICIAL DE SOCIEDADES}

Aqui, são abordadas as várias alternativas de dissolução judicial de sociedades, à luz dos dispositivos legais disciplinadores da matéria. Assim, discorremos sobre a dissoluçāo parcial de sociedades que envolve dissidência ou 
exclusão de sócio, dissolução parcial em face do passamento de sócio, bem como decretação de falência.

\section{CAPITULO 5 - JURISPRUDÉNCIA EM APURAÇĀO DE HAVERES}

São analisados e comentados os pronunciamentos judiciais da pesquisa realizada que envolve apuração de haveres na dissolução judicial de sociedades sob a óptica contábil.

\section{CAPÍTULO 6 - PRINCÍPIOS CONTÁBEIS E BALANÇO DE DETERMINAÇÃO}

Esse capitulo constitui a contribuição conceitual e operacional contábil de apuração de haveres em processos judiciais; compatibiliza os principios contábeis com as determinaçōes advindas do ordenamento juridico e da jurisprudência brasileira. O processo avaliatório judicial é operacionalizado, explicitando-se os procedimentos adotados para os itens monetários e não monetários; ao final do capítulo, é apresentado um modelo de balanço de determinação.

CAPITULO 7 - GOODWILL EM APURAÇÃO DE HAVERES: PROPOSIÇĀO

Aqui, são tratadas as várias visōes e contribuiçōes que envolvem o goodwill, sob a óptica dos doutrinadores contábeis e comercialistas. A par disso, são apresentadas as várias fórmulas de cálculo do goodwill e suas implicaçōes nas avaliaçōes judiciais, para, ao final, oferecermos uma proposição compativel com o processo avaliatório judicial.

\section{CAPITTULO 8 - DIFICULDADES E LIMITES PERICIAIS}

Por fim, são destacadas as inúmeras dificuldades e limites com que depara o perito em contabilidade quando em função judicial de apuração de haveres. Quando nāo há balanço de determinação, nem livros regularmente escriturados, são abordados e oferecidos alguns caminhos superadores de tais obstáculos. APÉNDICE

Em apêndice, é apresentada, como resultado de todo o debate exposto ao longo do presente trabalho, proposta de modelo de laudo pericial contábil e roteiro de apuração de haveres. 


\section{DEFINIÇÃO DE TERMOS UTILIZADOS NO TRABALHO}

Apresentamos a seguir um glossário de termos utilizados no desenvolvimento deste trabalho.

Apuração de haveres - É o procedimento judicial ordenado pelo magistrado, desenvolvido por perito em contabilidade, que tem por meta a avaliação das quotas societárias, ou seja, a mensuração da participação societária de sócio dissidente, excluido, ou pré-morto em sociedades contratuais.

Balanço especial - $\dot{E}$ o balanço patrimonial elaborado pelos sócios remanescentes de sociedade contratual na data-base do evento, para efeito de reembolso do valor das quotas societárias, em atendimento a dispositivo do contrato social.

Balanço de determinação - É o balanço patrimonial elaborado pelo perito em contabilidade, em função judicial, que é utilizado para determinar o montante dos haveres que cabe ao sócio dissidente, excluido ou aos herdeiros de sócio prémorto.

Balanço de liquidação - É o balanço patrimonial elaborado pelo liquidante de sociedade dissolvida totalmente.

Data-base do evento - É a data da declaração da dissidência societária, ou de falecimento de sócio pré-morto.

Descontinuidade involuntária - Corresponde ao encerramento da atividade empresarial, por decretação judicial, ou por desapropriaçāo estatal.

Descontinuidade voluntária - Corresponde ao encerramento da atividade empresarial, que ocorre pelo término do empreendimento, ou pela vontade coletiva de sócios ou acionistas.

Dissolução judicial de sociedade - É a decretação judicial de dissolução societária, total ou parcial, a requerimento de qualquer interessado.

Dissolução societária parcial - É a decretação da exclusão de sócio do quadro societário, operando-se a continuidade da sociedade com o sócio, ou sócios 
remanescentes, e determinando-se a apuraçăo de haveres do sócio retirante, ou falecido.

Dissolução societária total - É a decretação do fim da vida da sociedade, realizando-se a venda dos ativos e o pagamento das dividas e a distribuição do saldo porventura existente entre os sócios.

Goodwill adquirido - É um ativo intangível originário da diferença entre o preço de aquisiçăo de determinada participação societária e o valor dos elementos patrimoniais que a compōem; referida diferença é denominada ágio.

Goodwill não adquirido - É um ativo intangível que se forma naturalmente pela combinação dos ativos na atuação da empresa.

Patrimônio líquido a valores de mercado - Corresponde ao patrimônio líquido da sociedade na data-base, em que os elementos patrimoniais são avaliados a valores de mercado, incluindo o goodwill adquirido e nāo adquirido.

Sociedade em marcha - É uma sociedade em funcionamento, com caracteristicas e qualidades específicas e determinada estrutura de ativos e passivos que serão objeto de avaliaçāo.

Sócio dissidente - É o sócio que, discordante, propõe, perante o poder judiciário, a dissolução parcial ou total da sociedade.

Sócio excluido - É o sócio excluido pelos demais, mediante alteração contratual realizada pela maioria societária.

Sócio pré-morto - É o sócio que, pertencente ao quadro societário, veio a falecer. 


\section{CAPITULO 1 - AVALIAÇÃO DE SOCIEDADES NA CONTINUIDADE}

Avaliação de sociedades em marcha é assunto de alta complexidade teórica e técnica, muito embora se trate, em sua essência, de tema simples, qual seja, o de se responder qual é o valor de uma sociedade em funcionamento. Pergunta simples que exige 0 desenvolvimento de inúmeros procedimentos técnicos e rigorosas consideraçōes teóricas.

Como fator inerente à avaliação de sociedades, surge o denominado goodwill, ${ }^{1}$ tema altamente polêmico no âmbito da Contabilidade, já que envolve questionamentos teóricos, como, por exemplo, definir o que seja ativo e sua mensuração e as implicaçōes da adoçāo dos próprios princípios contábeis no conteúdo das demonstrações contábeis especiais ou balanço de determinação, base da apuração dos haveres em processos judiciais.

Por ora, fique assentado que neste trabalho é assumido que o goodwill corresponde à capacidade que determinado patrimônio tem de gerar valor acima do que se possa considerar como normal; constitui-se no sobrevalor ou plus, como entendem os juristas que militam na área do Direito Comercial.

Permeando o tema, há, na verdade, polêmica mais ampla, ou seja, a do valor económico, do valor dos fluxos financeiros no tempo, dos valores ou dos preços que as pessoas ou entidades estāo dispostas a investir ou a pagar e que envolvem a teoria da utilidade, a incerteza e o risco.

Para apreendermos a magnitude e a relevância da avaliaçāo de sociedades em marcha, embora não seja este o tema central deste trabalho, entretanto, em alguns aspectos muito pertinente, a seguir são abordadas as várias alternativas que demandam procedimentos avaliatórios.

\footnotetext{
O tema goodwill e sua mensuração serão tratados amplamente no Capitulo 7.
} 


\subsection{A QUEM INTERESSA}

Muitos são os interessados na avaliação de sociedades, visto que pode atender a várias finalidades; entre elas, as mais significativas são:

a. alienação: venda ou compra;

b. fusão, incorporação e cisão;

c. admissão de novos investidores;

d. captação de recursos de terceiros para implementação da capacidade operacional;

e. reembolso de capital;

f. apuração de haveres;

g. encerramento de atividades: fechar ou continuar? vender ou continuar?

\subsubsection{Avaliação para fins de alienação: venda ou compra}

A avaliação para fins de alienação envolve um conjunto de medidas e estudos que interessam tanto ao vendedor quanto ao comprador.

0 vendedor tem interesse em conhecer e evidenciar vantagens $e$ desvantagens em relação ao capital aplicado e sua rentabilidade futura, comparando-as com o provável preço de venda da sociedade.

Já o comprador estará interessado em dimensionar suas possibilidades de ganhos futuros em confronto com a aplicação de seus recursos, indagando qual a melhor alternativa de investimento, se adquirir determinado empreendimento, ou carreá-los para outros mais rentáveis.

Assim, tanto o comprador como o vendedor terāo interesse em conhecer alguns fatores especificos da avaliação da entidade, tais como: (a) os lucros potenciais; (b) $\circ$ ativo líquido; (c) as cotaçōes das ações no mercado, se companhia 
aberta (ou de ações de companhias similares); (d) a capacidade de pagamento de dividendos.

Alguns fatores podem conduzir - comprador e vendedor - à realizaçāo de uma operação de compra e venda de uma entidade.

São razōes para a aquisição de uma entidade, entre outras, as que seguem:

a. lucratividade indicada;

b. eliminação de concorrentes;

c. diversificação da linha de produtos;

d. expansāo da capacidade de produção;

e. extensão da área geográfica de mercado;

f. aquisição de fonte segura ou favorecida de fornecimento

g. aquisição de talento administrativo;

h. aquisição de know-how técnico ou de marketing;

i. melhoria ou ampliação dos meios de distribuição.

Para quem está querendo desfazer-se de um negócio, podem ser razōes ponderáveis para a venda de uma entidade:

a. a companhia estar operando com prejuizo;

b. os proprietários/administradores desejarem aposentar-se;

c. faltar capital para financiar a expansão necessária;

d. haver problemas de mercado, técnicos (dificuldades de acesso a novas tecnologias), com fornecedores, que podem afetar adversamente as operaçōes futuras;

e. existirem sérias discordâncias entre acionistas ou sócios majoritários que exerçam também cargos de gerência ou que desejam a divisāo da sociedade. 
É claro que as razões especificadas não esgotam o assunto. Correspondem a alguns indicadores que podem conduzir pessoas ou grupos de pessoas à realização do negócio.

O comprador deve, ainda, levar em consideração alguns aspectos negociais, como, por exemplo: (a) confiança no relatório dos avaliadores; (b) fator tempo nas negociaçōes do contrato final; (c) controle das garantias contratuais; (d) sobrepreço condicionado a cláusulas de desempenho.

De sua parte, o vendedor deve considerar alguns aspectos do negócio, tais como: (a) planejamento de suas novas atividades (poderá ser negociada cláusula de nāo-competiçăo); (b) cláusulas de garantia, bem como de eventuais retençōes contratuais vinculadas ao desempenho futuro.

A forma de pagamento, aspecto ponderável na avaliação, interessa tanto ao vendedor quanto ao comprador, por influenciar na fixação do preço do negócio.

\subsubsection{Avaliação para fins de fusão, incorporação e cisão}

O processo concentracionista das atividades empresariais é fenòmeno que acompanha a transformação do sistema capitalista, resultante da transformação da economia que provoca modificaçōes "sobretudo em relação aos processos de produção e circulação mas, também em grande parte, para subtrair-se às proibições e às dificuldades de ordem fiscal".

BULGARELLI diz:

'dos cartéis defensivos, 'pools', 'corners', 'rings', 'trusts', passou-se ao 'konzen', aos consórcios, aos grupos, às 'holdings', às sociedades de investimento, às 'joint ventures', sem, é claro, olvidar-se a forma mais radical e ao ver de alguns a mais perfeita de todas elas, ou seja, a fusão e a

2 Waldirio BULGARELLI, Fusdes, incorporaçðes e cisঠes de sociedades, p. 21. 
incorporação, que permaneceram ao lado das demais como uma constante". ${ }^{3}$

Sem entrarmos na diferenciação juridica, relativamente ao aspecto econômico são perseguidos, tanto na fusão quanto na incorporação, alguns objetivos, a saber:

a. racionalização da produção e da circulação de produtos e serviços;

b. agregação de tecnologia;

c. reorganização da estrutura administrativa e gerencial;

d. eliminação da concorrência;

e. redução de custos administrativos.

Contudo, segundo BULGARELLI, o maior deles, embora não explícito, é a busca de posição monopolistica.

Várias, portanto, podem ser as motivaçōes que levam à fusão ou incorporaçăo e, assim, a avaliação das entidades seguirá as razōes dessas motivaçōes.

HOUSSIAUX, (Apud BULGARELLI) destaca que as motivaçōes permeiam o processo avaliatório, provocando valores diversos. Qualifica as motivaçōes em três categorias:

"19) absorções realizadas com a finalidade de obter recursos próprios necessários para o crescimento, recursos esses que podem ser: novos equipamentos; clientela; pessoal; rede comercial; novas técnicas; pessoal qualificado e de direção e recursos de caixa disponiveis;

$\left.2^{2}\right)$ fusões com a finalidade de, por exemplo, aumentar a dimensão da empresa pela reintegração das filiais comuns no seio do grupo; $e$

$\left.3^{\underline{a}}\right)$ absorções como meio de supressão da concorrência, caso em que o valor da empresa adquirida pela incorporadora não é determinado pelo simples exame dos ativos físicos, mas principalmente por uma análise, 
levando em consideração o ganho decorrente da posição dominante que terá a incorporadora com a supressão da concorrente. ${ }^{\text {,4 }}$

$\mathrm{Na}$ cisão, deparamos com a divisão de sociedade com a transferência de parcelas patrimoniais para sociedades já existentes ou especialmente constituidas para tal finalidade.

Ela pode originar-se de um procedimento para desconcentrar atividades de sociedades muito grandes, ou para provocar a especialização de atividades; pode, também, resultar de dissidências societárias resolvidas de forma amigável.

As figuras juridicas de incorporação, fusão e cisão de sociedades encontram-se perfeitamente tipificadas na Lei $n^{\circ} 6.404$, de 15 de dezembro de 1976, recentemente alterada pela Lei $n^{0} 9.457,{ }^{5}$ de 5 de maio de 1997, assim:

"Art. 227. A incorporação é a operação pela qual uma ou mais sociedades são absorvidas por outra, que thes sucede em todos os direitos $e$ obrigações.

Art. 228. A fusão é a operação pela qual se unem duas ou mais sociedades para formar empresa nova que thes sucederá em todos os direitos $e$ obrigações.

Art. 229. A cisão é a operação pela qual a companhia transfere parcelas do seu patrimônio para uma ou mais sociedades, constituidas para esse fim ou já existentes, extinguindo-se a companhia cindida, se houver versão de todo o seu patrimônio, ou dividindo-se o seu capital, se parcial a versão."

A citada lei determina que referidas operaçōes realizem-se somente após a devida avaliação do patrimônio líquido das sociedades que serāo incorporadas, fusionadas ou cindidas, por três peritos ou empresa especializada, e o laudo avaliatório deve ser apreciado e aprovado pelos acionistas ou quotistas.

Ibidem, p. 23.

Waldirio BULGARELLI, et al., Reforma da lei das sociedades por açठes. 


\subsubsection{Avaliação para fins de admissão de novos investidores}

A avaliação para a finalidade de admissão de novos investidores pressupõe, inicialmente, análise das condições em que os mesmos participarão do empreendimento.

Assim, é necessário considerar se os novos investidores:

a. serāo admitidos como acionistas minoritários ou majoritários?

b. subscreverão, no caso de sociedade anônima, açōes ordinárias ou preferenciais?

c. integralizarão suas subscriçōes em dinheiro ou em bens (produtos, tecnologia etc.)?

d. participarão da administração da sociedade?

Os pontos retromencionados são básicos e relevantes na determinação da avaliação da sociedade para a admissão de novos investidores.

Sob a óptica, por exemplo, da admissāo de novos investidores, cuja participaçāo irá dar-lhes o controle da sociedade, é evidente que, no processo avaliatório, deve ser considerado um plus que será exigido por quem perde a condição de mando.

\subsubsection{Avaliação para fins de captação de recursos de terceiros}

Quando se fala em captaçāo de recursos de terceiros para implementação da capacidade operacional de uma sociedade, procura-se determinar se esses recursos serão destinados ao reforço do capital de giro ou para aquisição de bens de produção.

Dentro da dinâmica de mercado, pode a sociedade buscar recursos para atender a seu capital de giro nos bancos comerciais ou, ainda, no caso de sociedades anônimas, por meio da colocação de debêntures. 
É evidente que, no primeiro caso, a avaliação será feita mais em função da capacidade de liquidez da entidade, uma vez que, captado o recurso, deverá a sociedade, no prazo ajustado, devolvê-lo com os encargos financeiros contratuais.

Já no que concerne à colocação de debêntures, o investidor - debenturista - procurará fazer um exame do nivel de desempenho operacional da entidade, da rentabilidade oferecida, da garantia pelo pagamento dos rendimentos e, ainda, do prazo da aplicação e da possibilidade de conversão em ações.

Entretanto, os recursos captados de terceiros podem ser direcionados para a aquisição de bens de produção, objetivando a expansão da capacidade operacional.

Nesse enfoque, é conveniente ressaltar que a avaliação será efetuada segundo padrões especificos, especialmente quanto às garantias oferecidas, 0 retorno do investimento, o estudo da rentabilidade, da viabilidade econômicofinanceira do empreendimento, cronograma de execução, plano de aplicação dos recursos, bem como análise dos principais indicadores económico-financeiros da entidade.

Dessa forma, verificamos que a avaliação adquire um aspecto bem diferente dos até aqui abordados, posto que a análise passa a ser efetuada partindo-se de uma situação preexistente combinada com a projeção de seu desempenho, tanto econômico, quanto financeiro, com os recursos de terceiros a serem injetados na sociedade.

Nuanças semelhantes são encontradas também nos processos de abertura de capital das sociedades, com lançamento de açöes nas bolsas de valores, com ênfase no estudo do risco, já que, ao contrário das debêntures, as ações são lançadas sem qualquer garantia de rendimento.

Não podemos olvidar que os procedimentos de lançamento de valores mobiliários no mercado, inclusive quanto ao preço de emissão, sāo disciplinados pela Comissão de Valores Mobiliários (CVM). 


\subsubsection{Avaliação para fins de reembolso de capital}

Algumas possibilidades da vida societária podem ensejar a necessidade de avaliação patrimonial para efeito de devolução ao acionista ou quotista do valor das açōes ou quotas.

Na sociedade anônima, o acionista dissidente de deliberação da assembléia geral tem, em determinadas situaçōes, direito ao resgate do valor das açōes das quais é titular, como disposto no art. 45 e respectivos parágrafos, alterado pela Lei $n^{\circ} 9.457$, de 5 de maio de 1997.

Essa Lei alterou, significativamente, o valor do reembolso, como vemos no comentário de PENTEADO, verbis:

"A única modificação substancial consta dos $\S \S 1^{\circ}, 3^{\circ}$ e $4^{\circ}$, nos quais foi suprimido o piso do valor de reembolso anteriormente assegurado pela redação original da Lei $n^{\circ} 6.404 / 76$ (valor patrimonial das ações), com a instituição de alternativa, desde que prevista no estatuto, de pagamento ao acionista dissidente de importância inferior àquele valor, correspondente ao percentual de sua participação no 'valor econômico da companhia', apurado por três peritos ou empresa avaliadora, constante de laudo fundamentado, com a indicação dos critérios de avaliação e dos elementos de comparação adotados e instruido com os documentos relativos aos bens avaliados' (art. $45, \S 3^{\circ}$, c. c. art. $8^{\circ}, \S \S 1^{\circ}$ e $\left.4^{\circ}\right) .^{\prime 6}$

$\mathrm{Na}$ sociedade por quotas de responsabilidade limitada, existe a possibilidade de reembolso de haveres quando o sócio já não deseja continuar na sociedade e, de forma amigável e consensual, resolvem os sócios proceder à avaliação da sociedade, de modo a fixar o valor da participação do sócio retirante.

É de ser observado que o contrato social normalmente dispōe sobre essa hipótese de retirada, definindo, inclusive, a forma de pagamento.

6 Citado por Waldirio BULGARELLI, et al., op. cit., p. 42. 


\subsubsection{Avaliação para fins judiciais}

Algumas circunstâncias da vida das sociedades provocam a necessidade de avaliação por determinação judicial.

Podem ser citadas as seguintes possibilidades de avaliação:

a. em processo de inventário por falecimento de sócio de sociedade organizada sob a forma juridica de limitada;

b. em processo de dissolução parcial, por dissidência entre sócios de sociedade limitada, ou mesmo por exclusão de um deles;

c. em processo envolvendo sociedade irregular ou de fato;

d. por expropriação legal de qualquer empreendimento empresarial.

Os primeiros casos tratam da chamada apuração de haveres de sócio falecido e de sócio dissidente ou excluido.

O último reflete a intervenção do Estado no domínio econômico.

\subsubsection{Encerramento de atividades: fechar ou continuar?}

Diversos fatores ponderáveis podem determinar a decisão de encerramento voluntário de atividades de uma sociedade por vontade dos sócios ou acionistas. Podemos citar os que seguem:

a. prejuizos constantes e dificil recuperação econômica;

b. políticas administrativas geradoras de encargos incompativeis com a estrutura da entidade;

c. concorrência desleal que impossibilite à sociedade uma atuaçāo dentro de parâmetros normais;

d. surgimento de outros campos mais atrativos e rentáveis para a aplicaçāo de capitais; 
e. desilusāo do empresário que não consegue realizar seus objetivos;

f. baixa rentabilidade do capital aplicado;

g. falecimento do principal administrador, especialmente, em sociedades familiares.

Podemos notar que os fatores apontados são realmente significativos quanto à continuidade ou não de um empreendimento. Assim, a decisão pela descontinuidade deve ser precedida de uma avaliação da sociedade pelo valor de realização de seus ativos e um estudo acurado das possibilidades de continuidade do empreendimento.

\subsection{AVALIAÇÃO DE SOCIEDADES EM MARCHA}

A avaliaçāo de uma sociedade em marcha, ou seja, em funcionamento, coloca-nos diante de determinada estrutura de ativos e passivos que serăo objeto de avaliação. É empreendimento preexistente, com determinadas características e qualidades.

Devemos ter presente que qualquer empreendimento empresarial tem por justificativa propiciar a seus proprietários o máximo de riqueza possivel.

Mensurar tal empreendimento significa buscar um ou vários valores prováveis em função das motivações provocadoras de tal medição.

Então, quanto vale uma sociedade em funcionamento, na continuidade?

Segundo HARRINGTON, ${ }^{7}$ vale o preço justo que algum investidor esteja disposto a pagar pela sociedade, levando em conta o montante do retorno esperado, a época em que o retorno será recebido e o risco inerente ao próprio retorno esperado.

1 D. R. HARRINGTON, Modern portfolio theory, the capital asset pricing model and arbitrage pricing theory: a user's guide. p. 1. 
KINGSTON e MCQUILLAN ${ }^{8}$ entendem que vale o mais alto preço obtido no mercado, aceito por investidores prudentes, bem informados, que nāo realizam transaçōes sob impulsos.

BLACKMAN ${ }^{9}$ entende que as sociedades devem ser avaliadas não pelo que obtiveram no passado, mas pelo que podem ser capazes de conseguir no futuro. O retorno esperado, ou sua expectativa, é o fator determinante de seu valor.

COPELAND, KOLLER e MURRIN ${ }^{10}$ afirmam que o valor da sociedade é determinado em função de seu cash flow futuro descontado e é criado valor quando as entidades investem determinado montante de capitais cujos retornos sāo superiores ao próprio custo do capital aplicado.

Vale, em nosso modo de ver, o.que as características e qualidades da sociedade, preexistentes, podem proporcionar em termos de resultados futuros, ou seja, quanta riqueza pode ser gerada com a riqueza existente.

Temos que considerar que uma sociedade em marcha é um investimento ou um conjunto de investimentos que se materializa em determinado nivel de ativos com objetivos de produção, comercializaçāo ou de prestaçāo, de determinados produtos, mercadorias e serviços.

Temos, portanto, dois aspectos a considerar: a riqueza existente e a por vir.

Vejamos a primeira ordem do que deve ser mensurado: a riqueza existente.

A riqueza existente é aqui considerada como todos os ativos tangiveis e intangiveis, pertencentes a determinada sociedade, em determinado momento. Os passivos sāo tratados como meras restriçōes dos ativos.

A idealizaçāo, em termos avaliatórios, é avaliar os ativos por seu valor econômico, entendendo-se este como o "valor atual máximo dos resultados econômicos futuros esperados, no cálculo do qual a taxa de desconto é a do custo de oportunidade de igual risco". ${ }^{11}$

8 J. P. R. KINGSTON, P. E. MCQUILLAN. Valuations of business: a pratical guide, p. 9.

9 I. BLACKMAN, The valuation of privately-held business: state of art techniques for buyers, sellers and advisers, p. 5.

10 T. COPELAND, T. KOLLER, J. MURRIN, Valuation: measuring and managing the value of companies, p. 93.

11 Eliseu MARTINS, Contribuiçào à avaliaçđo do ativo intangivel, p. 41. 
A riqueza futura, estimada hoje, será maior, igual ou menor que a riqueza existente?

A resposta poderá ser obtida com metodologias de cálculo diferenciadas; entretanto, a mais usual tem sido a de buscar resposta que possibilite a comparação da riqueza existente em confronto com a riqueza futura provável, considerando a entidade como um fluxo gerador de caixa no tempo.

Esta não é a única abordagem possivel; entretanto, é a mais comum na literatura especializada.

À medida que, a médio e longo prazo, todos os ativos produzirão ou se transformarão em numerário, os resultados econômicos futuros são considerados como um fluxo de caixa, no tempo previsto.

A questão que se põe quanto aos resultados econômicos futuros é a de que se trata de uma estimativa, já que apenas são esperados, ou seja, trata-se de uma expectativa diagnosticada com base em determinados parâmetros adotados por quem elabora a estimativa; conseqüentemente, resulta de uma análise subjetiva.

A utilização do custo de oportunidade de igual risco pressupōe a existência de riscos semelhantes, remunerados de forma homogênea, no mesmo tempo e espaço. E, em tese, considera, ainda, a possibilidade de mobilidade dos capitais investidos na sociedade.

Segundo essa abordagem, os ativos, registrados ou não, são assim considerados e avaliados pelo resultado futuro que se espera obter.

E. MARTINS, ao definir Ativo, considera que os ativos, em termos contábeis, precisam ser fundamentados economicamente como agentes que proporcionam resultados econômicos. ${ }^{12}$ Nesse enfoque, é secundário o valor de aquisição dos agentes, mesmo porque as entidades não adquirem, por exemplo, máquinas para vendê-las enquanto tal, mas o que resulta das máquinas: os produtos fabricados ou serviços por elas prestados.

12 Ibidem, p. 30. 
Aqui situamos o grande descompasso entre a Contabilidade tradicional $\Theta$ processo avaliatório de sociedades que considera o valor econômico dos ativos, amarrada que está aquela aos denominados Principios Fundamentais de Contabilidade, em especial, o do registro pelo valor original e a convenção da objetividade.

É oportuno discorrermos, em apertada sintese, sobre o principio e a convenção citados.

Preliminarmente, cabe destacar o art. 18, do Decreto $n^{\circ} 3.708$, de 10 de janeiro de 1919, que determina sejam aplicados às sociedades limitadas determinados dispositivos das sociedades anônimas, verbis:

“Art. 18. Serão observadas quanto às sociedades por quotas, de responsabilidade limitada, no que não for regulado no estatuto social, e na parte aplicável, as disposições da lei das sociedades anônimas."

Inscrevemos nesse rol a elaboração das demonstraçōes financeiras e, por conseqüência, os critérios de avaliação do ativo e passivo, como disposto na Lei $n^{\circ}$ 6.404 , de 15 de dezembro de 1976, arts. 176, 183 e 184.

Da citada lei, o art. 177 merece destaque, já que determina a obediência aos Principios Fundamentais de Contabilidade, assim:

"Art. 177. A escrituração da companhia será mantida em registros permanentes, com obediência aos preceitos da legislação comercial e desta lei e aos principios de contabilidade geralmente aceitos, ${ }^{13}$ devendo observar métodos ou critérios contábeis uniformes no tempo e registrar as mutações patrimoniais segundo o regime de competência."

Embora não explicito, o regime de competência na lei anterior já era observado, como disposto no art. 132 (Decreto-lei $n^{0} 2627 / 40$ ), assim:

“Art. 132. Para que os haveres sociais possam entrar no cálculo dos lucros liquidos, não é necessário que se achem recolhidos em dinheiro à caixa;

\footnotetext{
${ }^{13}$ Terminologia anterior à ediçăo da Resoluçăo no 750, de 29 de dezembro de 1993, do Conselho Federal de Contabilidade.
} 
basta que consistam em valores definitivamente adquiridos ou em títulos ou papéis de crédito reputados bons." 14

Embrionariamente, já vislumbramos no Código Comercial de 1850 o regime de competência, pois seu art. 12 estipula que as vendas a prazo devem ser escrituradas, no mesmo dia, em assento separado. ${ }^{15}$

Com a criação da Comissāo de Valores Mobiliários (CVM), esta, por força do disposto no art. 22, Lei $n^{\circ}$ 6.385, de 7 de dezembro de 1976, recebeu competência para expedir normas aplicáveis às companhias abertas no que concerne a padrōes de contabilidade (parágrafo único, inciso IV).

Em 5 de fevereiro de 1986, vem a lume a Deliberaçāo $n^{\circ} 29$, editada pela Comissão de Valores Mobiliários, que aprovou o pronunciamento do Instituto Brasileiro de Contadores (Ibracon) denominado Estrutura Conceitual Básica da Contabilidade.

Em fins do ano de 1993, como resultado do consenso das várias instâncias envolvidas (Conselho Federal de Contabilidade, Instituto Brasileiro de Contadores, Comissão de Valores Mobiliários e Banco Central do Brasil), surge a Resolução no 750, editada pelo Conselho Federal de Contabilidade, que dispõe sobre os Principios Fundamentais de Contabilidade.

Os Principios Fundamentais de Contabilidade aprovados pela Resolução no 750, do Conselho Federal de Contabilidade, de 29 de dezembro de 1993, representam as diretrizes obrigatórias no exercício da profissāo contábil, pois, como consta de seu art. $2^{\circ}$,

"representam a essência das doutrinas e teorias relativas à Ciência de Contabilidade, consoante o entendimento predominante nos universos cientifico e profissional de nosso País. Concernem, pois, à Contabilidade no

\footnotetext{
${ }^{14}$ Decreto-lei no 2.627 , de 26 de setembro de 1940 .

${ }^{15}$ Código Comercial Brasileiro - Lei $\mathrm{n}^{\circ}$ 556, de 25 de junho de 1850: "Art. 12. No diário é o comerciante obrigado a lançar com individuaçāo e clareza todas as suas transaçzes de comércio, letras e outros quaisquer papéis de crédito que passar, aceitar, afiançar ou endossar, e em geral tudo quanto receber e despender de sua e alheia conta, seja por que titulo for. sendo suficiente que as parcelas de despesas domésticas se lancem englobadas na data que forem extraidas do caixa. Os comerciantes a retalho deverajo lançar diariamente no diário a soma total de suas vendas a dinheiro, em assento separado, a soma total das vendas fiadas no mesmo dia."
} 
seu sentido mais amplo de ciência social, cujo objeto é o patrimônio das Entidades." ${ }^{16}$

Como um desses Princípios, temos o do REGISTRO PELO VALOR ORIGINAL, ${ }^{17}$ que determina que os componentes patrimoniais devem ser consignados nos livros pelos valores originais da época das transaçōes, ou seja, com base nos valores de entrada. Pressupōe, portanto, que o valor da transação reflete a expressão econômica de determinado ativo no momento da transação.

O Princípio sob exame deve ser interpretado em conjunto com o PRINCÍPIO DA ATUALIZAÇĀO MONETÁRIA, que determina o reconhecimento dos efeitos da alteração do poder aquisitivo da moeda nacional, o que possibilita a manutenção dos valores originais nos patamares da época da transação.

As Convenções refletem condicionamentos aos Princípios. Nesse sentido a Convenção da Objetividade.

Segundo IUDICIBUS, sob a óptica dos procedimentos utilizados:

"O termo objetividade pode ser encarado: (a) sob o ponto de vista da referência a uma documentação formal ou tipo de evidência que suporte o registro e sua avaliação; (b) sob o ponto de vista da tangibilidade do objeto passivel de mensuração; (c) sob o ponto de vista da posição de neutralidade que a Contabilidade deveria manter". ${ }^{18}$

HENDRIKSEN (Apud IUDICIBUS), relativamente à mensuração, considera a convenção da objetividade com conceitos distintos. Faz reflexão sobre quatro conceitos:

"(1) mensuraçōes impessoais ou que existem fora da mente da pessoa que as está realizando;

(2) mensurações baseadas no consenso de experts qualificados;

(3) mensurações baseadas em evidência verificável; e

16 Conselho Regional de Contabilidade do Estado de São Paulo, Os principios fundamentais de contabilidade, as normas brasileiras de contabilidade e o código de ética profissional, p. 21.

17 Sérgio de IUDíCIBUS, Teoria da contabilidade, p. 52. O autor denomina-o "Custo original como base de valor".

18 Sérgio de IUDíCIBUS, Análise de balanços, p. $43-44$. 
(4) valor da dispersão estatistica das mensurações de um atributo quando realizada por vários pesquisadores." 19

O conteúdo e a abrangência dos Principios Fundamentais de Contabilidade foram objeto de Apêndice aprovado pela Resolução $n^{0}$ 774/94, do Conselho Federal de Contabilidade.

Referidos Principios, segundo consta do citado Apêndice, refletem "o núcleo central da própria Contabilidade", são "as vigas mestras" da ciência contábil,

"valem para todos os patrimónios, independentemente das Entidades a que pertencem, as finalidades para as quais são usados, a forma jurídica da qual estão revestidos, sua localização, expressividade e quaisquer outros qualificativos, desde que gozem da condição de autonomia em relação aos demais patrimônios existentes". ${ }^{20}$

Não são diretivas operacionais. Estas se operacionalizam por meio das Normas que, tendo por norte os Princípios, "estabelecem ordenamentos sobre o como fazer, isto é, técnicas, procedimentos, métodos, critérios etc., tanto nos aspectos substantivos, quanto nos formais". ${ }^{21}$

Os Princípios, em nosso país, são obrigatoriamente observados na formulação das Normas Brasileiras de Contabilidade.

Todo o arcabouço normativo emanado dos Princípios Fundamentais de Contabilidade, por meio de sua aplicação universal, visa propiciar ao usuário, interno ou externo, informações padronizadas de qualquer tipo ou tamanho de sociedade.

Sérgio de IUDÍCIBUS, Teoria da contabilidade, p. 66-67.

20 Conselho Regional de Contabilidade do Estado de Săo Paulo, op. cit., p. 28

21 Ibidem, p. 28. 


\subsection{MODELOS AVALIATÓRIOS}

DAMODARAN comentando a existència de inúmeros modelos comungando caraterísticas comuns, entende ser mais profícua uma abordagem mais ampla. Dessa óptica diz:

"Em termos gerais, há três abordagens para a avaliação. A primeira, avaliação por fluxo de caixa descontado, relaciona o valor de um ativo ao valor presente dos fluxos de caixa futuros esperados relativos àquele ativo. A segunda, a avaliação relativa, estima o valor de um ativo, enfocando a precificação de ativos 'comparáveis' relativamente a uma variável comum, como lucros, fluxos de caixa, valor contábil ou vendas. A terceira, avaliação de direitos contingentes, utiliza modelos de precificação de opções." ${ }^{22}$

O modelo de avaliação por fluxo de caixa descontado possibilita duas alternativas avaliatórias: (a) avaliação do patrimônio líquido; e (b) avaliação de toda a sociedade.

A primeira alternativa consiste na mensuração da sociedade em termos de fluxo de caixa do patrimônio líquido ou fluxo de caixa líquido do acionista. ${ }^{23}$

O valor do patrimônio líquido resulta do desconto do fluxo de dividendos esperados pela taxa de retorno requerida pelos acionistas sobre o patrimônio liquido.

A segunda alternativa considera que o valor da empresa corresponde aos fluxos de caixa esperados descontados pelo custo médio ponderado do capital. ${ }^{24}$

Como é perceptivel, as alternativas levam em consideração fluxos de caixa e taxas de desconto diferenciadas. DAMODARAN alerta:

"O erro-chave a ser evitado é combinar fluxos de caixa e taxas de desconto, uma vez que descontar fluxos de caixa para o patrimônio liquido a valor

:- Aswath DAMODARAN, Avaliaçăo de investimentos: ferramentas e técnicas para determinação do valor de qualquer ativo, p. 11.

3 Deduzidas todas as despesas, inclusive juros e principal.

24 Deduzidas todas as despesas operacionais e impostos, exclusive juros e principal. 
presente pelo custo médio ponderado de capital levará a um desvio crescente no valor da empresa, ao passo que descontar os fluxos de caixa para a empresa a valor presente pelo custo do patrimônio liquido produzirá um desvio decrescente no valor da empresa." 25

Cabe observar que o modelo de fluxo de caixa descontado agrega, por sua vez, determinados modelos de crescimento: crescimento estável e crescimento em duas ou três etapas.

Crescimento estável corresponde a determinada taxa de crescimento estimada correlacionada com a taxa de crescimento nominal da economia. Pressupõe, ainda, que as despesas de capital, de reposição de ativos, possam ser próximas das despesas de depreciaçāo, e que são desnecessários investimentos adicionais para manter a mesma estrutura operacional.

Crescimento em dois estágios envolve taxas de crescimento diferenciadas: uma para determinado periodo de crescimento extraordinário; outra para crescimento estável, com duração perpétua. Algumas reflexōes são necessárias. A primeira refere-se ao tempo de duração do periodo de crescimento extraordinário; a segunda, à queda abrupta da taxa de crescimento extraordinário para estável.

Crescimento em três estágios corresponde ao modelo anterior acrescido de um estágio de transiçāo entre a fase de crescimento extraordinário e a de crescimento estável.

Alguns cuidados devem ser observados no desenvolvimento e elaboraçāo do processo avaliatório, mesmo porque o modelo não pode ser aplicado de forma generalizada.

Os modelos de fluxos de caixa descontados sāo operados, considerando-se os modelos de crescimento expostos anteriormente.

DAMODARAN considera algumas situaçōes nas quais o modelo de fluxo de caixa descontado sofre restriçōes. ${ }^{26}$ Cita sociedades em dificuldades, originárias de fluxos de caixa negativos que resultam em patrimônio liquido negativo; sociedades

\footnotetext{
25 Aswath DAMODARAN, op. cit., p. 13.

26 Ibidem, p. 15-16.
} 
cujos lucros e fluxos de caixa têm comportamento cíclico, ou seja, sofrem os efeitos do comportamento da economia; sociedades com ativos não utilizados nas operações, portanto, não geradores de fluxo de caixa; sociedades possuidoras de patentes ou opções de produtos não utilizados nas operações, mas possuidores de valor; sociedades em processos de reestruturação que acarretam dificuldades na estimativa dos fluxos futuros de caixa; sociedades envolvidas em aquisiçōes, que requerem análise quanto à sinergia e ao efeito da mudança gerencial nos fluxos de caixa; sociedades de capital fechado que envolve a ausência de informações a serem utilizadas na mensuração do risco.

O modelo de avaliação relativa leva em consideração que o valor dos ativos decorre da comparação, do confronto com outros ativos semelhantes, utilizando alguns padrões comuns, tais como: lucros, receitas, fluxos de caixa. Tem por pressuposto que o mercado valoriza, adequadamente, as sociedades atuantes em determinado segmento de negócios.

Comparamos, por exemplo, o indice preço/lucro setorial médio com o mesmo indice da sociedade avalianda. Do mesmo modo, índice preço/valor contábil e indice preço/vendas.

A construção do índice a'ser utilizado na avaliação percorre dois caminhos. O primeiro "relaciona indicadores às informações básicas da empresa a ser avaliada - taxas de crescimento de lucros e fluxos de caixa, indices de pagamentos e risco", possibilitando evidenciar "o relacionamento entre indicadores e características da empresa". ${ }^{27} \mathrm{O}$ segundo relaciona-se com a elaboração dos indicadores de uma sociedade em face daquelas que the servem de paradigma.

Dois questionamentos envolvem o modelo de avaliação relativa: (a) a definição de sociedades comparáveis é subjetiva; e (b) a superavaliação e a subavaliação de sociedades comparáveis sancionadas pelo mercado.

O modelo de avaliação por direitos contingentes ou de precificaçăo de opções consiste em valorizar determinado ativo dentro de certos limites contingenciais. DAMODARAN diz:

27 Ibidem, p. 17. 
"Um ativo pode ser avaliado como uma opção de compra se seus pagamentos forem função do valor de um ativo subjacente. Se aquele valor exceder um nivel predeterminado, o ativo vale a diferença; caso contrário, nada vale. Poderá ser avaliado como uma opção de venda se acrescer valor à medida que o valor do ativo subjacente cair abaixo de um nivel préespecificado e se nada valer quando o valor do ativo subjacente exceder àquele limite." ${ }^{28}$

Algumas aplicaçōes são lembradas por DAMODARAN. É caso do patrimônio líquido como opção de compra sobre o valor da sociedade; a divida corresponde ao preço de exercício e o prazo da dívida mede a vida da opção, e acrescenta que

"uma patente pode ser analisada como uma opção de compra sobre um produto, com o desembolso do investimento necessário para o lançamento do projeto sendo considerado, preço de exercício da opção e a vida da patente constituindo o prazo até o vencimento da opção." ${ }^{29}$

O modelo comentado tem, por outro lado, algumas limitaçōes, especialmente quando se trata de opçōes de longo prazo, o que dificulta as estimativas de dividendos e a variância constante; sofre ainda limitação quando o ativo objeto da opção não apresenta negociação, causando a estimativa de valor em face da ausência de dados dos mercados financeiros.

FREZATTI, em artigo de grande profundidade, posiciona-se sobre o tema avaliaçăo, considerando três importantes vertentes de pensamento da Teoria de Finanças: (1) abordagem do fluxo de caixa descontado; (2) abordagem dos múltiplos; e (3) abordagem do resultado econômico residual. Privilegia a análise da terceira vertente, nela incluida o Economic Value Added (EVA), tendo por expoente mais importante a Stern Stewart \& Co. FREZATTI considera que o Resultado Econòmico Residual (RER) tem muitos méritos que suplantam os limites ou dificuldades inerentes, enumerando os seguintes méritos: 
“a) linguagem conceitual simplificada: Muito embora o conceito de resultado liquido após a remuneração não seja algo novo, o grande mérito de Stewart foi a simplificação da linguagem, tornando factivel e praticável uma abordagem até então considerada puramente acadêmica e por demais complexa;

b) não implica em ruptura mas sim agregação de conceitos: a utilização da base contábil é essencial para os cálculos dos valores necessários. Dessa maneira, O RER constitui-se em produto adicional da Contabilidade e não seu concorrente;

c) um único instrumento atende a vários interesses: Pode-se separar os interesses dos agentes em:

- análise do desempenho interno da organização;

- análise de investimento;

- análise do mercado;

- apura o resultado que remunera realmente todos os stakeholders envolvidos, levando em conta o risco;

- benchmarking quando usado para análise externa." 30

FREZATTI é de opiniāo que o RER pode ser entendido como "aquilo que sobra para a empresa depois que ela remunera, paga, retorna, recursos consumidos no seu processo". ${ }^{31}$

\subsection{MÉTODOS AVALIATÓRIOS}

Em primeiro lugar, temos o método contábil subordinado aos Principios e Convençōes Contábeis e refletido nas demonstraçōes contábeis usuais em que os itens patrimoniais são avaliados pelo valor original, admitindo-se a atualizaçāo

30 Fábio FREZATTI, Valor da empresa: avaliação de ativos pela abordagem do resultado econòmico residual. Cadernos de Estudos - Fipecafi. São Paulo, no 19, p. 61, set./dez. 1998.

31 Ibideın, p. 61. 
monetária e as receitas, e as despesas são reconhecidas de conformidade com o princípio da competência.

Considerando os modelos avaliatórios destacados na seção 1.3, podem ser observados três métodos avaliatórios: patrimonial, renda e comparação.

O método patrimonial leva em consideração que o valor dos ativos da sociedade pode ser avaliado com base nos seguintes critérios:

a. pelo custo de reposição;

b. pelo valor de saída;

c. pelo valor histórico; e

d. pelo valor de mercado.

O método da renda parte do valor econômico dos ativos da sociedade, ou seja, considera que os ativos valem o que podem gerar para o proprietário do mesmo, tendo por base:

a. o pay-back ou multiplicador de renda;

b. o valor atual do fluxo de caixa, ou de lucros;

c. a taxa interna de retorno e um múltiplo das vendas ou do lucro bruto.

Já o método da comparabilidade, como o próprio nome indica, busca encontrar, no mercado, transações semelhantes ao empreendimento que está sendo avaliado, a fim de permitir determinadas análises comparativas com a avaliação em curso.

Os métodos retro-apresentados, como pode ser observado, não são excludentes. É comum a utilização dos três métodos, de maneira simultânea, com pesos diferenciados; entretanto, o método da renda terá sempre maior relevância.

O método avaliatório em processos judiciais assumido neste trabalho, como será amplamente abordado no Capitulo 7 , consiste numa mescla do método patrimonial com alguns aspectos do método da renda.

Os elementos patrimoniais corpóreos ou tangiveis são avaliados pelo valor de mercado (método patrimonial) como determina a jurisprudência pátria; os 
elementos incorpóreos ou intangiveis são mensurados, adotando-se determinadas formulaçōes inerentes ao método da renda em função da determinação judicial de que deve ser considerado na apuração de haveres o goodwill, ou aviamento.

Independente do modelo avaliatório adotado, as demonstraçōes contábeis originárias do método contábil são submetidas a determinadas adaptaçōes afim de permitir processo avaliatório o mais adequado e correto possivel. São reelaboradas em função das premissas emanadas dos modelos avaliatórios, especialmente aquelas originárias do modelo de avaliação por fluxo de caixa descontado.

O balanço operacional é apresentado assim:

- os ativos são reclassificados em operacionais e não operacionais. Ativos operacionais são os utilizados nas operaçōes; são os que geram fluxo de caixa. Ativos não operacionais são os que não geram fluxo de caixa; não são utilizados nas operações; inserem-se nesse grupo as disponibilidades, pois estas não geram fluxo, são meio de pagamento;

- Os passivos são reclassificados como passivo operacional e passivo financeiro. $O$ passivo operacional corresponde às obrigações assumidas em funçāo das operaçōes. O passivo financeiro corresponde a todas as obrigaçōes financeiras para com terceiros.

A reclassificação dos itens patrimoniais, no que se refere ao objeto central deste trabalho, ou seja, apuração de haveres, é procedimento que requer análise rigorosa dos ativos e passivos constatados na data-base da avaliação. Especial atenção deve merecer o passivo financeiro. Financiamentos com taxas de juros privilegiadas afetam, positivamente, o valor da sociedade. Por outro lado, financiamentos com taxas de juros muito acima das praticadas pelo mercado afetam, negativamente, o valor da sociedade.

Aspecto importante que afeta o processo avaliatório é o relativo às operações de leasing, geralmente registradas quando do pagamento das parcelas mensais em despesas operacionais, sem qualquer registro patrimonial, tanto no ativo quanto no passivo. O processo avaliatório requer seja reconhecido esse tipo de operação, considerando-se como ativo operacional o valor do bem liquido de 
depreciaçäo e como passivo financeiro o saldo a pagar na data-base. Por outro lado, o resultado econômico é ajustado pelo efeito da depreciação e dos encargos financeiros.

Os ativos nāo operacionais, por exemplo, terreno para futuras instalações, são avaliados a valores de mercado. Patentes ou opçōes de produtos, como sugerido por DAMODARAN, podem ser avaliados a valores de mercado, ou utilizando o modelo de precificação de opçōes.

O balanço patrimonial reclassificado, em versão sintética, pode ser configurado assim:

\begin{tabular}{|c|c|c|}
\hline \multicolumn{3}{|c|}{ BALANÇO OPERACIONAL } \\
\hline Ativo circulante operacional & & \\
\hline Ativo permanente operacional & & \$ \\
\hline (=) Ativo operacional total & & S \\
\hline (-Passivo operacional & & \$ \\
\hline$\Leftrightarrow$ Ativo operacional liquido & & $\$$ \\
\hline (+) Ativo não operacional & & S \\
\hline (-) Passivo financeiro & & \\
\hline$\Leftrightarrow$ Património líquido & & \\
\hline
\end{tabular}

O balanço operacional analítico, respeitada a nomenclatura emanada da lei das sociedades por açōes (Lei $n^{\circ} 6.404 / 76$ ), pode ser representado como disposto na Figura 1, ao final deste capitulo.

O resultado contábil evidenciado na demonstração de resultado contábil é objeto, também, de ajustes reclassificatórios necessários ao procedimento avaliatório.

A fim de consignar corretamente o resultado do exercício, as receitas e as despesas, face à influência inflacionária sāo recalculadas, utilizando-se procedimentos de correção monetária integral.

A despesa operacional de leasing é subdividida em depreciação e despesa financeira. 
Detectada sazonalidade, especialmente, em sociedades ciclicas, é premente procedermos a uniformalização dos resultados econômicos.

As receitas e as despesas financeiras são consideradas após o lucro operacional. Desconsideram-se do resultado operacional os efeitos do passivo financeiro; nesse sentido, também a reclassificação dos resultados gerados pelos ativos nāo operacionais. Consideramos, exclusivamente, o lucro ou fluxo de caixa originário das operações.

Efetuados todos os ajustes, o resultado do exercício pode ser demonstrado da seguinte forma:

\begin{tabular}{|lrr|}
\hline & DEMONSTRAÇÃO DO RESULTADO & \\
& Contábil & Operacional \\
Lucro operacional & $\$$ & $\$$ \\
Receitas financeiras & $\$$ & \\
Despesas financeiras & $\$$ & \\
Resultados do ativo não operacional & $\$$ & \\
Resultados não operacionais & $\$$ & $\$$ \\
Lucro antes imposto de renda & $\$$ & $\$$ \\
Imposto de renda & $\$$ & $\$$ \\
Lucro liquido & $\$$ & \\
\hline
\end{tabular}

\subsection{LIMITES E FATORES QUE INFLUENCIAM O PROCESSO AVALIATÓRIO}

É pertinente ter presente que a adoçāo de qualquer modelo e do respectivo método gera sempre uma estimativa de valor, ou como afirma FALCINI

"uma avaliação econômica, ao contrário do que possa parecer, não é uma fixação concreta de um preço ou valor especifico para um bem, mas é uma estimativa de base, uma tentativa de estabelecer, dentro de uma faixa, um valor referencial de tendência, em torno do qual atuarão as forças de mercado." ${ }^{32}$ (Grifo nosso.)

32 Primo FALCINI, Avaliação econòmica de empresas: técnica e prática, p. 19. 
Qualquer procedimento avaliatório considera inúmeros fatores externos e seus impactos nos mercados ou setores de mercado em que a sociedade atua, como a seguir:

- as políticas económicas de governo (monetária, fiscal, rendas, propriedade) que afetam a distribuiçăo de renda, os montantes de investimento e de poupança, e o nível inflacionário poderão afetar os resultados econômicos da sociedade e, por isso, devem e são consideradas no processo avaliatório;

- o meio ambiente setorial em que se situa o empreendimento, no que se refere às forças atuantes nesse meio, é fator preponderante considerado no processo avaliatório;

- os concorrentes do setor, diretos ou potenciais, a ameaça de produtos substitutos, a força dos fornecedores e dos clientes, a evolução tecnológica, a disponibilidade e a qualificação dos recursos humanos são forças que influenciam e ameaçam os resultados econômicos almejados; portanto, são consideradas, tanto no momento da avaliação, quanto no da construção de cenários do provável comportamento dessas forças no futuro.

São fatores que afetam normalmente o processo avaliatório de sociedades em marcha; todavia, nos procedimentos judiciais, deparamo-nos com diretrizes emanadas dos tribunais que têm o condāo de modificar alguns aspectos relevantes dos modelos avaliatórios. Podem ser considerados relevantes os seguintes aspectos:

- Primeiro: o futuro operacional da sociedade não alcança nem beneficia o sócio retirante ou os herdeiros do sócio pré-morto. Isso implica duas adaptaçōes nos modelos avaliatórios: (a) os lucros operacionais utilizados são os históricos; e (b) não se utilizam os modelos de crescimento

- Segundo: não é possivel a utilização do beta de mercado. As sociedades limitadas não participam do mercado acionário. 
- Terceiro: o modelo de avaliação relativa é inaplicável. As sociedades limitadas não publicam suas demonstrações contábeis; portanto, inexistem dados disponiveis, o que inviabiliza a utilização do modelo.

Todos esses fatores analisados anteriormente podem afetar a geração e o nivel de lucros futuros da sociedade objeto da avaliaçăo. São fatores de risco do negócio, tema mais aprofundado no Capítulo 2. 


\section{ATIVO CIRCULANTE OPERACIONAL - ACO \\ Duplicatas a receber}

(-) Prov. p/devedores duvidosos

Titulos a receber (origem operacional)

Adiantamentos a fornecedores e diversos

Estoques vendáveis

Outros créditos operacionais

Impostos a recuperar

Despesas antecipadas

C/Correntes operacionais (controladas, coligadas)

ATIVO PERMANENTE OPERACIONAL - APO

Investimentos, inclusive ágio (se controladora)

Ativo imobilizado liquido utilizado nas operaçōes

Adiantamentos p/compra imobilizado

Ativo imobilizado (leasing)

Diferido (se em processo de amortização)

PASSIVO OPERACIONAL - PO

Fornecedores de bens e serviços

Obrigaçōes sociais e previdenciárias

Obrigaçōes tributárias correntes

Provisōes: tributárias, trabalhistas, sociais

Adiantamento de clientes

Contas a pagar

C/Correntes operacionais (controladas, coligadas)

Lucros a pagar

ATIVO OPERACIONAL LIQUIDO - AOL (ACO + APO - PO)

DISPONIBILIDADES - D

Caixa e bancos

Aplicações de curto prazo

Aplicaçōes em ouro de curto prazo

ATIVO NÄO OPERACIONAL - ANO

Titulos a receber a longo prazo não operacionais

Diferido (se em constituição)

Depósitos judiciais

Estoques obsoletos

Investimentos (incentivos fiscais, eletrobrás, ações)

$\mathrm{C} /$ Correntes financeiras (controladas, coligadas)

C/Correntes sócios a receber

PASSIVO FINANCEIRO - PF

Títulos a pagar (NPs) de curto e longo prazo

Saques a descoberto (bancos)

Financiamentos

Leasing a pagar

Empréstimos nacionais e estrangeiros

Duplicatas descontadas

Parcelamento de tributos

$\mathrm{C} /$ Correntes financeiras (controladas, coligadas)

C/Correntes de sócios a pagar

PATRIMÓNIO LÍQUIDO - PL (AOL + D + ANO - PF)

Figura 1 Balanço operacional 


\section{CAPITULO 2 - VALOR, VALOR ECONÔMICO, RISCO E TAXA DE JUROS}

Uma das questōes cruciais em avaliação de sociedades, privada ou judicial, é aquela relativa ao valor total da sociedade avalianda, inserido que está, naquele, o valor do goodwill não adquirido, ou do aviamento no entender de ilustres juristas.

Os usuários da informação contábil em processos judiciais olvidam às vezes que valor é diferente de preço.

O perito em contabilidade, ao elaborar a apuraçăo de haveres consignada em seu laudo técnico, apura um valor estimado da sociedade avalianda, com base em determinadas premissas e diretrizes técnicas, entre elas o valor do dinheiro no tempo, o risco do negócio, a taxa de desconto dos lucros futuros.

Não the compete chegar ao preço da participação societária. Este resulta de negociações entre compradores e vendedores nas transações privadas; todavia, em processos judiciais tais tratativas não sucedem.

É dever de ofício proceder o magistrado à conciliação entre as partes. Poderia ser uma oportunidade processual chegar-se ao preço da quota do sócio retirante, ou pré-morto; entretanto, é condição que depende totalmente da vontade das partes.

\subsection{VALOR, VALOR ECONÔMICO E TAXAS DE JUROS}

Uma das questōes básicas em economia é a do conceito de valor.

RICARDO, em sua clássica obra Principios de economia política e tributação, apresenta seu entendimento assim: "possuindo utilidade, as mercadorias 
derivam seu valor de troca de duas fontes: de sua escassez e da quantidade de trabalho necessária para obtê-las"'.

É o prenúncio da teoria do valor-trabalho, na qual a "idéia básica dessa teoria é que na troca de mercadorias tende a haver uma troca de quantidades iguais de trabalho, utilizado em sua produção", segundo palavras de SINGER. ${ }^{2}$

SINGER diz que a transformaçāo de valores em preços foi posteriormente confirmada pela

“contribuição fundamental de Sraffa em A Produção de Mercadorias por Meio de Mercadorias. Importa aqui meramente ressaltar que o modelo de Sraffa confirma a brilhante intuição de Ricardo de que os preços relativos das mercadorias se determinam simultaneamente pela quantidade de trabalho nelas incorporado e pela repartição da renda entre capital e trabalho ou, dito de outra forma, pela participação relativa dos salários e lucros no produto". 3

Surge, conseqüentemente, uma medida de valor objetiva, qual seja, a de que o valor do produto social é avaliado pelo trabalho social contido no produto ou serviço.

Se o valor do produto social, expresso na somatória de bens e serviços produzidos por determinada sociedade, pode ser mensurado objetivamente, significa que as mercadorias e os serviços chegam ao mercado já com seus preços estipulados, suficientes para cobrir adequadamente os custos de produção e certa margem de lucro.

A parcela da produçāo nāo consumida no próprio processo produtivo recebe a denominação de poupança, ou excedente econômico.

A formação da poupança e as taxas de juros são temas recorrentes na avaliaçāo de sociedades.

David RICARDO, Principios de economia politica e tributação, p. 43.

Paul SINGER. Apresentação. IN: David RICARDO, op. cit., p. XXV.

3 Ibidetn, p. XXVII. 
FISHER, em sua obra clássica A teoria do juro, coloca-nos diante de questões fundamentais quanto à taxa de juros. Entende o autor existirem duas questões que envolvem a taxa de juros; a primeira "porque existe a taxa de juros"; a segunda "como a taxa de juro é determinada". 4

A taxa de juros tem funçāo primordial de

"transportar o futuro para o presente, isto é, o problema de determinação do capital-valor da renda futura. O valor do capital deve ser computado do valor de sua renda líquida futura estimada e não vice-versa". 5

Para FISHER tal problematização se aplica tanto à propriedade quanto à riqueza, açōes, terras, edificações, máquinas, pois todos esses ativos representam um "capital-valor descontado como qualquer outro capital", acrescentando que "fora o risco, cada um tem um valor de mercado, dependente apenas dos mesmos dois fatores, os beneficios, ou retornos, esperados pelo investidor e a taxa de juro de mercado pela qual esses beneficios são descontados." E, Capital-valor é "renda capitalizada e nada mais" e não podemos olvidar que ganhos de capital "são meramente capitalização de renda futura. Nunca são renda presente". ${ }^{6}$

O autor em foco entende o juro como "a relação entre o pagamento e o valor monetário" das coisas, por exemplo, é denominador entre um aluguel pago e o valor capitalizado desse aluguel, enfatizando que "a taxa de juro é o preço mais universal de toda estrutura de preço".

Já a determinaçāo da taxa de juro segundo FISHER resulta "do grau de impaciência sobre o qual toda a comunidade pode concorrer de modo que se garanta o completo equilibrio do mercado de empréstimos", ou, ainda, que "a taxa de juro registra no mercado a taxa de preferência marginal comum pela renda presente sobre a renda futura, como determinada pela oferta e demanda da renda presente e futura." 8

\footnotetext{
Irving FISHER, $A$ teoria do juro: determinada pela impaciência de gastar renda e pela oportunidade de investi-la, p. 18.

lbidem, p. 19.

Ibidem, p. 20-21-24.

Ibidem, p. 28.

Ibidem. p. 79.
} 
Essa troca de renda futura por renda presente é ilustrada por FISHER assim:

"Aqueles que, para começar, têm um alto grau de impaciência lutam para adquirir mais renda presente à custa de renda futura, e assim tendem a elevar a taxa de juros. Estes são os que tomam empréstimos, os gastadores, os vendedores de propriedades que geram uma renda remota, tais como obrigações e ações. Por outro lado, aqueles que, para começar, têm uma taxa de preferência baixa lutam para adquirir renda futura às custas da renda presente, e assim tendem a baixar a taxa de juro. Estes são os que cedem empréstimos, os poupadores, os investidores." 9

Para esse cenário, FISHER leva em conta quatro principios: dois relativos à impaciência; dois relativos ao mercado:

Principios da Impaciência:

"1. empírico - a taxa de preferência temporal, ou grau de impaciência, de cada individuo depende do seu fluxo de renda;

2. desejabilidade máxima - por meio de alterações nos fluxos de renda produzidos através de empréstimos ou vendas, os graus de impaciência marginais para todos os individuos no mercado são igualados uns aos outros e à taxa de juro do mercado." 10

Principios do Mercado:

"1. equilibrio de mercado - a taxa de juro do mercado será tal que equilibrará completamente o mercado, isto é, fará as cessões ou contratações de empréstimos mais gerais, compra e vendas de renda iguais para cada período de tempo;

2. reembolso - todos os empréstimos são reembolsados com juros, isto é, o valor presente dos pagamentos, calculado no momento do contrato iguala o valor presente dos reembolsos. Em termos mais gerais, as alterações de soma ou subtração, ou retiradas do fluxo de renda original de uma pessoa, 
efetuadas através da compra e venda em dois pontos diferentes, são tais que a soma algébrica dos seus valores presentes é zero." 11

Realizada a acumulaçāo que, como vimos anteriormente, depende da participação relativa dos salários e dos lucros no produto, esses lucros estāo disponiveis para novos investimentos, ou para consumo dos capitalistas. Os proprietários dos capitais poderão ampliar seus próprios investimentos ou transferilos para outras aplicaçōes mediante a interferência do mercado de capitais, na busca de melhor oportunidade que proporcione o máximo valor presente.

FISHER, abordando os Principios da Oportunidade de Investimento que pressupōe a possibilidade de mais de um uso para os recursos, traça um principio geral, verbis:

"O principio geral é que, entre as várias opções abertas ao capitalista, ele escolhe a mais vantajosa ou, mais especificamente, aquela que, comparada com qualquer outra, oferece vantagens que, no valor presente, a uma dada taxa de juro, ultrapassem as desvantagens. Mas essa é, evidentemente apenas uma outra formulação do principio original de que o uso será aquele que tiver o máximo valor presente a uma dada taxa de juro." 12

Em sintese, a taxa de juro é o mecanismo que permite a compra e venda de fluxos de renda futuros a valor presente.

A análise tradicional supōe o sistema capitalista na forma concorrencial. Isto significa que o próprio sistema impulsiona, por uma questāo de sobrevivência, a acumulação, ou, em outras palavras, é inerente ao sistema. A sobrevivência dos produtores capitalistas depende de novos investimentos.

Para KALECKI,

"As decisões de investimento acham-se intimamente ligadas à acumulação interna de capital, isto é, à poupança bruta das firmas. ${ }^{13}$ Haverá uma

"Ibidem, p. 81.

12 Ibidem, p. 99.

13 Michal KALECKI, Teoria da dinâmica económica: ensaio sobre as mudanças cíclicas e a longo prazo da economia capitalista, p. 81: KALECKI define assim: "Em sentido restrito, a poupança bruta das firmas consiste na depreciação e nos lucros não distribuidos. Juntaremos mais um item. contudo, a 'poupança 
tendência a empregar essa poupança em investimentos, e, além disso, o investimento pode ser financiado por dinheiro vindo de fora, atraido pela acumulação do capital da empresa. A poupança bruta das firmas portanto expande os limites impostos aos planos de investimento pelas restrições do mercado de capitais e pelo fator do risco crescente. ${ }^{14}$

O custo do capital para investimento tenderá a ser inferior à taxa de lucro de determinado empreendimento (rendimento marginal do investimento, abaixo citado), senão, em tese, não haveria procura por capitais adicionais. Se a taxa de juros for igual à taxa de lucro, não há acumulação, quando muito uma transferência de capitais de um setor para outro.

Entretanto, não se pode olvidar o alerta de ROBINSON, de que

"é possivel dizer, contudo, que em geral uma taxa de juros baixa tenderá a estimular tanto o investimento como o consumo, já que, quando se espera que os custos de um empréstimo em termos do seu próprio produto sejam menores que o rendimento marginal do investimento que ele cobre, a renda futura esperada pode ser aumentada sem que a própria familia tenha que realizar poupança." ${ }^{15}$

KALECKI (ApUd ROBINSON) aponta que: "os planos de investimento em qualquer periodo são função da poupança bruta das firmas durante o periodo imediatamente anterior, bem como da taxa de lucro esperadan; ${ }^{16}$ todavia, a autora é cética quanto à tendência proposta por KALECKI apoiada num fluxo de invençōes que proporcionariam aumento dos lucros, o que estimularia, por sua vez o investimento.

São suas essas palavras:

"Essa parece ser uma fonte muito precária de motivação para a acumulação; se a acumulação contínua resultou de fato dessa motivação, à maneira da idade de ouro, a taxa real de lucro terá sido constante",

pessoal' que os grupos controladores investiram nas suas companhias por meio de subscrição de açðes" (p. 8I).

14 Risco crescente está relacionado com o aumento do capital investido em relação ao capital preexistente.

15 Joan V. ROBINSON, Ensaios sobre a teoria do crescimento econômico, p. 307.

16 Ibidem, p. 367. 
acrescentando que, em seu modelo

"a motivação a investir é pensada em termos de uma taxa de crescimento desejada, ao invés de um estoque de capital desejado. A taxa de crescimento natural permite mas não provoca o crescimento real. $A$ tendência real do crescimento é gerada de dentro pela propensão a acumular inerente ao sistema." ${ }^{17}$

Toda essa vertente econômica apresentada faz-se necessária ao tema apuração de haveres à medida que são calculados sobre o patrimônio líquido da sociedade, a valores de mercado; e deve ser entendido como um estoque de capital, a valor presente de determinada sociedade na data-base; conseqüentemente, os haveres de qualquer sócio são uma parcela desse estoque de capital mensurado a valor presente.

Assim, com base nos pressupostos econômicos abordados, é premente a formulação de alguns questionamentos:

19) como o patrimônio liquido da sociedade é um estoque de capital, qual será seu fluxo de renda no tempo? Será perene ou volátil, por conta do risco?

Considerando que os sucessos ou insucessos futuros, após a data-base, como preconizado pelos comercialistas estudados, não atingem a quota a ser reembolsada, só resta considerar no processo avaliatório de apuração de haveres, o retrospecto dos resultados econômicos obtidos no passado pela sociedade avalianda.

$\left.2^{\circ}\right)$ é possivel ao sócio retirante apoiar-se no principio da oportunidade preconizado por FISHER, ou seja, está presente a oportunidade de investir em outro tipo de negócio mais rentável, ou de máximo valor presente, enquanto se processa a apuração e a liquidação de seus haveres?

O sócio dissidente ou excluido e os herdeiros de sócio pré-morto envolvidos em processo judicial de dissolução parcial de sociedade não têm escolha, pois só

17 Ibidem, p. 367. 
podem dispor do valor do reembolso de seu estoque de capital obedecidas as etapas processuais correspondentes, o que muitas vezes significa longa espera, remunerada apenas com juros contratuais ou legais de $6 \%$ ao ano, o que para os sócios remanescentes é uma situação cômoda, ou, em termos financeiros, uma forma barata de financiamento, considerando a taxa de juros da economia brasileira.

39) Poderá o sócio retirante, na qualidade de credor que é, a partir do seu desligamento, pleitear perante o magistrado o máximo valor presente da parcela que lhe cabe no estoque de capital?

Nos pleitos judiciais, como se observará no Capitulo 5, a jurisprudência predominante estabelece que os haveres sāo apurados considerando-se a plenitude de todos os elementos patrimoniais a valores de mercado, mandando incluir nessa universalidade patrimonial o goodwill ou aviamento, tudo demonstrado em balanço de determinação.

4) Qual a taxa de juro que permite a compra e venda de fluxos de renda futuros a valor presente, relativos à parcela do estoque de capital pertencente a determinado sócio, considerando que este tem obviamente preferência pelo tempo presente?

Em procedimentos privados de negociação de compra e venda de negócios, especialmente nos processos de privatização, é notório que vem sendo adotada a taxa de $15 \%$ ao ano, que na espécie assemelha-se à taxa de juros de longo prazo preconizada por KALECKI para os investimentos.

Em processos judiciais, os haveres apurados, ou seja, o estoque de capital do sócio retirante em moeda constante, a partir da data-base, está sujeito ao acréscimo de juros contratuais, normalmente de $12 \%$ ao ano, ou, se o contrato social for omisso, de juros legais de $6 \%$ ao ano. 


\subsection{RISCO E PREÇOS}

O futuro, época em que são concretizados os resultados econômicos da entidade, é sempre uma possibilidade repleta de incertezas, que precisam ser transformadas em alternativas de risco, mensuráveis em termos probabilísticos.

FISHER introduz o elemento risco assim:

"a renda futura está sempre sujeita a alguma incerteza, e esta incerteza deve, naturalmente, ter uma influência sobre a taxa de preferência temporal, ou grau de impaciência, de seu possuidor",

e acrescenta que "o futuro remoto usualmente é menos conhecido do que o futuro imediato, um fato que por si só significa risco ou incerteza". ${ }^{18}$

Risco, para ALLA, é "a possibilidade, para os agentes participantes do mercado, de não realizarem o rendimento esperado".19

SOLOMON, abordando o tema Custo do Capital, em nota explicativa, diz: "Existe, realmente, incerteza quando não sabemos ou não podemos empregar a distribuição de probabilidades dos benefícios esperados". ${ }^{20}$

SECURATO diz: "A definição mais simples e prática nos parece ser dada por SOLOMON e PRINGLE: risco é o grau de incerteza a respeito de um evento". ${ }^{21}$

SÁ apresenta-nos uma diferenciaçäo entre risco e incerteza:

Pode-se falar em risco, ou em uma situação de risco, quando

"não sabemos com certeza que evento resultará de uma decisão tomada. Sabemos, porém, a exata probabilidade da ocorrência de cada um dos eventos possiveis relacionados à decisão tomada". ${ }^{22}$

18 Irving FISHER, op. cit., p. 56.

19 Jean ALLA, L'évaluation de l'entreprise: de la theorie a la pratique, p. 43. No original: "Nous définirons ainsi le risque comme la possibilité pour les agents sur le marché, de ne pas atteindre le rendement espéré."

21 José Roberto SECURATO, Decisðes financeiras em condiçðes de risco, p. 21.

22 Geraldo Tosta de SÁ. Investimentos no mercado de capitais, p. 204. 
A incerteza tem conotaçăo diferente, pois "uma situação é dita de incerteza, quando não temos conhecimento objetivo da distribuição de probabilidades associadas aos eventos que poderão resultar.' ${ }^{23}$

Uma decisão sobre determinado tipo de investimento, calculada a probabilidade de ocorrência dos eventos possiveis em relação à decisão tomada, portanto, uma situação de risco, envolve, segundo os tratadistas, dois tipos de risco, ou seja, o risco total apresenta dois componentes: (a) risco sistemático; e (b) risco não sistemático.

EID JUNIOR, ao abordar a questão da determinação do valor intrínseco de um ativo, afirma que o mesmo é resultante de dois fatores: risco e retorno. Diz ainda que o estudo do risco deu um grande salto (1921)

"com a abordagem feita por Knight. Este autor separou o risco em duas categorias: (a) riscos diversificáveis; (b) riscos não diversificáveis. Ele afirmou que a remuneração do lucro é devida apenas aos riscos não diversificáveis. Este trabalho pode ser considerado um marco pois foi 0 primeiro a trabalhar de forma sistemática a relação entre risco e lucro". ${ }^{24}$

Essa classificação do risco será, mais tarde, retomada por SHARPE, ao propor seu modelo de análise, denominado Capital Asset Pricing Model (CAPM), que considera que o risco total é composto, ou subdividido em: (a) risco sistemático ou não diversificável; e (b) risco não sistemático ou diversificável. ${ }^{25}$

O risco sistemático ou não diversificável tem sua origem nas flutuaçōes do próprio sistema econômico, a saber:

a. variação da taxa de juros que afeta todas as taxas de retorno da economia;

b. perda do poder de compra dos recursos aplicados em ativos sob processo inflacionário;

23 Ibidem, p. 204.

24 William EID JUNIOR, $A$ reduçđo do risco das carteiras de investimento através da diversificaçđo aleatórla: estudo de caso na Bovespa, p. 11.

2s William F. SHARPE, Gordon J. ALEXANDER, Investments. 
c. flutuações nos mercados secundários que afetam as taxas de retorno dos ativos negociados.

São, portanto, situações de risco que afetam todos os ativos, não passiveis de eliminação pela diversificação proposta pelos teóricos da Teoria dos Portfólios.

Entretanto, são essas situações de risco sistemático ou não diversificável que vão justificar o mercado pagar determinada remuneração.

O risco não sistemático ou diversificável é intrinseco ao próprio investimento realizado; portanto, eliminável pela diversificação.

As fontes básicas desse tipo de risco são:

a. risco financeiro, ou seja, a possibilidade de a sociedade investida tornarse insolvente;

b. risco de administração, relacionado com a qualidade das decisões tomadas pela administração do empreendimento; e

c. riscos do setor, que afetam determinado segmento específico.

LEITE, comentando o risco total afirma que

"a decomposição completa do risco total e a análise de cada fonte geradora de risco é uma tarefa extremamente complexa, pois a variabilidade total dos retornos é influenciada por todos esses agentes de forma heterogênea. Certamente, haverá efeitos compensatórios que anulam, assim, causas que agem em oposição entre si. Entretanto, do ponto de vista conceitual, a classificação dos componentes do risco total assume importância fundamental. Como veremos adiante, o desmembramento do risco total entre Risco Sistemático e Não Sistemático terá, também, enorme interesse prático" ${ }^{26}$

O processo decisório em condições de risco envolve a necessidade de oferecer ao investidor as várias curvas de indiferença ou alternativas, com base em suas preferências e utilidade.

26 Helio de Paula LEITE, Introdução à administração financeira, p. 408. 
Os tratadistas são unânimes em afirmar que são infinitas as curvas de indiferença que podem ser traçadas para cada investidor.

Além desses aspectos, a decisão por determinada curva de indiferença tem relação intima com o tamanho da riqueza de cada pessoa ou investidor, tudo comparado com o montante do investimento a ser realizado em relação à própria riqueza individual, isto é, maiores ou menores riscos poderão ser assumidos em funçāo do peso do investimento em relaçāo à riqueza total do individuo.

Posto isto, é de se indagar qual o risco do interessado no reembolso da quota de capital? Vários são os riscos. O estoque de capital, representativo da participação do sócio retirante da sociedade está sujeito aos dois riscos: diversificável e não diversificável, tipificados em momento anterior. Está sujeito ao risco diversificável porque sem poderes ou oportunidade para mudar de investimento; depende de procedimentos judiciais com rito próprio; sofre os efeitos dos riscos não diversificáveis, especialmente em função da variação da taxa de juro da economia.

Ao leque de fontes básicas do risco diversificável, podemos acrescentar algumas possibilidades especificas, tais como:

- os sócios remanescentes podem esvaziar o empreendimento, transferindo para terceiros o estabelecimento empresarial;

- podem constituir nova sociedade apropriando-se de todo acervo patrimonial corpóreo e incorpóreo existente;

- podem quebrar voluntária ou involuntariamente o empreendimento.

São possibilidades de risco que não afetam a apuração dos haveres, enquanto procedimento técnico, em face do entendimento juridico predominante. Afetam, sim, as condiçōes objetivas de sua liquidação.

Enquanto nāo se processa o reembolso, os remanescentes permanecem com a mesma estrutura empresarial e o estabelecimento empresarial intacto, sem modificação do nivel de atividade. 
Os comercialistas pátrios estudados sāo enfáticos em afirmar que os sucessos ou insucessos da atividade empresarial observados a partir da data do evento nāo atingem a quota a ser reembolsada, além do que, decretada a dissoluçāo, cessam os vínculos societários e, por isso, fica prejudicada a participaçāo nas decisōes sociais, fiscalização dos negócios, nos lucros e no pro labore, diferentemente, do que sucede, por exemplo, na Inglaterra,

"onde os membros da partnership podem optar, enquanto se processa a avaliação de sua participação societária, entre continuar recebendo sua parte dos lucros sociais, ou a juros, à aliquota de $5 \%$ ao ano, sobre a parte do patrimônio social correspondente à sua quota". ${ }^{27}$

Decretada a dissolução parcial e apurado e homologado o valor do reembolso na data-base, como já enfatizado anteriormente, esse valor nominal está sujeito a atualizaçāo monetária e ao acréscimo de juros contratuais ou legais, aqueles fixados no contrato social, estes fixados em lei na base de $6 \%$ ao ano.

As considerações retro-oferecidas tèm intima ligação com o tema avaliação de sociedades em processos judiciais, à medida que afetam ou podem afetar todo 0 processo avaliatório e, conseqüentemente, a riqueza mensurada e seu reembolso.

27 Fábio Ulhoa COELHO, Curso de direito comercial, v. 2, p. 451. 
A descontinuidade societária é sempre uma possibilidade no mundo dos negócios. Pode-se caracterizar como voluntária, se os sócios ou acionistas deliberam seu fim; pode ser involuntária, quando a sociedade tem decretada sua falência; e, também, por intervenção do Estado, por meio de desapropriação.

Pode, também, ser involuntária por morte de sócio; entretanto, como veremos no Capitulo 5 , a jurisprudência pátria admite que a sociedade constituida por dois sócios, se um deles vier a falecer, possa continuar, desde que o sócio remanescente recomponha o quadro societário no prazo de um ano, ou que continue como firma individual. Tal entendimento visa preservar a manutençăo do negócio, com a manutenção de postos de trabalho.

\subsection{DESCONTINUIDADE VOLUNTÁRIA OU CONTRATUAL}

A descontinuidade voluntária carateriza-se pelo encerramento da sociedade, ou seja, os sócios ou acionistas, consensualmente, decidem dissolver a sociedade, procedendo à respectiva liquidaçāo e extinção. As razōes que podem levar a tal decisão são as expostas na seçāo 1.1.7, Encerramento de atividades: fechar ou continuar.

A descontinuidade voluntária opera-se também nas sociedades que já nascem com prazo determinado de duração. Terminado o prazo avençado, a sociedade entra em processo de dissolução, em conformidade com as cláusulas contratuais. 
A descontinuidade voluntária tem rito próprio, qual seja, insere-se no capitulo da Liquidação de Sociedades, mais especificamente no art. 344, do Código Comercial, verbis:

"Art. 344. Dissolvida uma sociedade mercantil, os sócios autorizados para a gerir durante a sua existência devem operar a sua liquidação debaixo da mesma firma, aditada com a cláusula - em liquidação, salvo havendo estipulação diversa no contrato, ou querendo os sócios, a aprazimento comum ou por pluralidade de votos em caso de discórdia, encarregar a liquidação a algum dos outros sócios não gerentes, ou a pessoa de fora da sociedade."

O liquidante sócio ou estranho à sociedade tem as obrigaçōes previstas nos arts. 345 e 346 do já citado diploma, a saber:

"Art. 345. Os liquidantes são obrigados:

I. A formar inventário e balanço do cabedal social nos quinze dias imediatos à sua nomeação, pondo-o logo no conhecimento de todos os sócios; pena de poder nomear-se em Juizo uma administração liquidadora à custa dos liquidantes, se forem sócios, e não o sendo, não terão direito à retribuição alguma pelo trabalho que houverem feito;

II. A comunicar mensalmente a cada sócio o estado da liquidação, debaixo de mesma pena;

III. Ultimada a liquidação, a proceder imediatamente à divisão e partilha dos bens sociais; se os sócios não acordarem em que os dividendos se façam na razão de tantos por cento à proporção que os ditos bens se forem liquidando, depois de satisfeitas todas as obrigações da sociedade.

Art. 346. Não bastando o estado da caixa da sociedade para pagar as dívidas exigidas, é obrigação dos liquidantes pedir aos sócios os fundo necessários, nos casos em que eles forem obrigados a prestá-los."

A dissoluçāo voluntária está aqui apenas anunciada, mesmo porque é tema apenas subsidiário ao presente trabalho. Entretanto, surgindo discórdia entre os 
sócios, poderá provocar o surgimento de procedimento judicial, e, nesse caso, teremos a dissolução judicial, cujo rito será mais à frente abordado.

\subsection{DESCONTINUIDADE INVOLUNTÁRIA OU DECRETADA}

A descontinuidade involuntária opera-se por decisão judicial de quebra, disciplinada pela Lei de Falências, Decreto-lei no 7.661, de 21 de junho de 1945, e legislaçăo posterior, procedendo-se a liquidaçăo forçada dos ativos e passivos pertencentes à entidade falida. Por se tratar de dissolução societária com rito próprio, este tópico será ampliado no capitulo seguinte, que cuida da Dissolução Judicial de Sociedades.

Outra possibilidade de descontinuidade involuntária é a originária da intervenção estatal, e a mais usual é a desapropriação do estabelecimento empresarial, para a realização de obras de interesse público.

Nessa hipótese, se o valor indenizado for inaceitável pelo empresário, isso dá azo à propositura de procedimento ordinário de indenização por perdas e danos, que se resolvem mediante prova pericial contábil de apuração dos danos emergentes, ou seja, tudo o que se perdeu, inclusive as despesas de mudança do local do estabelecimento, cumulado com a apuração de lucros cessantes, representado por tudo o que o empresário deixou de ganhar, procedendo-se, inclusive, ao cálculo do ponto comercial (luvas).

\subsection{AVALIAÇÃO NA DESCONTINUIDADE E BALANÇO DE LIQUIDAÇÃO}

A descontinuidade voluntária ou por decreto judicial gera procedimento avaliatório especifico. $O$ acervo patrimonial é avaliado por seus valores prováveis de realização.

Tratando-se de dissoluçāo total de sociedade, abandonamos o princípio do custo como base de valor e procedemos à avaliação do acervo patrimonial pelos 
valores de saída, mais especificamente, os valores prováveis de realização, ou, como disposto na lei, procedemos ao inventário e balanço dos ativos e passivos pertencentes à sociedade dissolvenda. Formamos um balanço de liquidação.

ESTRELLA, discorrendo sobre as várias espécies de balanço, entre elas o de liquidação, assim se expressou:

"Pelo que respeita ao balanço de liquidação, entretanto, as coisas se passam de modo assaz diferente. Os bens que aderem à sociedade e, normalmente, só tém existéncia em função dela (nome comercial, sinais distintivos, desenhos, modelos, concessões, despesas de instalação, aviamento, clientela e direito ao ponto ou local), são bens que com ela se extinguem e, por isto, não podem, corretamente, ser considerados como valores realizáveis. Computam-se, no entanto, as reservas e fundos acumulados e, bem assim, as valorizações de ativo (até onde estas venham a concretizar-se pela venda dos bens respectivos, ou partilha destes em espécie). Desse jeito fixado o ativo liquidando, a sua avaliação é orientada com base no preço provável de venda."1

Acrescenta, ainda, que năo podem ser desprezados os efeitos do encerramento das atividades sobre o passivo, mais precisamente, quanto às indenizaçōes trabalhistas, por conta do despedimento dos empregados, as próprias despesas com a liquidação e o cancelamento de contratos, como, por exemplo, os de locação, enfim, todas as responsabilidades originárias dos negócios interrompidos.

Não podemos olvidar, também, as responsabilidade comerciais, tais como: venda de produtos com garantia, ou a exigència de manutenção de estoques de peças de reposição, para determinados ramos de negócio e, ainda, outras inerentes ao negócio (a título exemplificativo: as construtoras são obrigadas a responder por danos de construção pelo prazo de 5 anos: art. 1245, Código Civil), e tudo isto exige a constituição de fundos monetários, ou de estoques, para fazer frente a todas as prováveis contingências.

Hernani ESTRELLA, Apuração dos hoveres de sócio, p. 148. 
Os ensinamentos de ESTRELLA merecem ser considerados em seu tempo histórico, mormente, pela revolução que se assiste nos dias de hoje quanto aos ativos intangiveis.

Marcas, patentes, ponto comercial podem ter valor de realização. Competirá ao liquidante proceder aos estudos necessários para verificar a potencialidade de realização desses ativos intangiveis. As marcas, por exemplo, em face dos procedimentos de terceirização da produção e dos serviços, podem ter vida independente, podem ser objeto de licenciamento, mediante franchising.

Obviamente, despesas antecipadas e ativos diferidos, os dois em processo de amortização, quando em marcha a sociedade, por principio são excluídos do balanço de liquidação; entretanto, há que observar se referidos ativos, em face dos eventuais contratos que lhes dão guarida, prevêem a possibilidade de ressarcimento pelo tempo não decorrido, caso em que serão avaliados pelos valores prováveis de ressarcimento.

Entende-se, também, desnecessária a consideração, a nosso ver equivocada do ponto de vista técnico, a respeito de reservas e fundos acumulados consideradas pelo ilustre jurista, pois, no balanço de liquidação, avaliados os ativos e passivos a valores prováveis de realização, por diferença, surge, automaticamente, o patrimônio líquido provável da sociedade liquidanda.

Quando veio a lume a obra de Hernani Estrella, estava em vigor o Decretolei $n^{\circ} 2.627$, de 26 de setembro de 1940, que dispunha sobre a sociedades por açōes. Esse Decreto-lei, nos arts. 129 e 130, mencionava fundos de depreciação e de amortização, reserva para créditos de liquidação duvidosa, fundo de reserva, fundos de reserva especiais e fundos de previsão. Entendemos que o autor, ao usar a expressão fundos acumulados referia-se aos termos mencionados nos citados artigos.

Por força da vigência da Lei $n^{\circ} 6.404 / 76$ que substituiu o mencionado Decreto, referidos termos sofreram modificação não apenas de nomenclatura, mas também de significado: 
- fundos de depreciação e de amortização passaram a denominar-se Depreciação e amortização acumulada, não mais com o conceito de fundo, mas como reconhecimento da perda de capacidade produtiva dos bens imobilizados e diferidos, mediante taxas de depreciação e amortização aplicadas sobre referidos ativos;

- reserva para créditos de liquidação duvidosa, hoje conhecida como Provisão para devedores duvidosos, reconhecendo-se as prováveis perdas sobre os créditos a receber, a título de despesas e não mais como destinação de lucros;

- fundo de reserva equivale à Reserva legal atual; fundos de reservas especiais e fundos de previsão correspondem às atuais Reservas de lucros; trata-se de destinaçōes do lucro do exercício, mas sem a conotação de vinculação com determinados ativos.

Em sintese, no balanço de liquidação devem ser consignados, apenas, os ativos e passivos suscetiveis de realizaçăo monetária, em processo de liquidação ordenada.

Não é diferente em outros paises. VENTURA ${ }^{2}$ aborda o tema como exposto a seguir.

$\mathrm{Na}$ Alemanha, os liquidantes elaboram balanço e relatório explicativo, denominado de balanço de abertura, ponto de partida da liquidação. Nesse, são consignados os valores que presumidamente possam ser alcançados quando das alienaçōes, não aparecendo no lado do passivo nem a conta de capital social nem as reservas.

$\mathrm{Na}$ França, é exigido do liquidante a organização de um inventário do ativo e passivo da sociedade submetido à assembléia dos sócios, o qual também constitui a referência inicial para a prestação de contas do liquidante.

$\mathrm{Na}$ Itália, compete aos antigos administradores apresentarem ao liquidante a conta da gestão entre o último balanço e a data de abertura da liquidação e a este

2 Raúl VENTURA. Dissolução e liquidação de sociedades: comentários ao código das sociedades comerciais (portuguesas), p. 282 ss. 
proceder a um inventário do estado do ativo e passivo do patrimônio. Esse inventário será analítico e valorizado, considerando os valores prováveis de realizaçāo por meio dos procedimentos de liquidação.

Em Portugal, os administradores submetem à aprovaçāo dos sócios o inventário, balanço e contas de sua gestão, reportados à data da dissolução. Se os administradores forem relapsos, compete ao liquidante fazê-lo. Entretanto, cabe ressalvar tratar-se de inventário e balanço elaborados nas mesmas regras das demonstraçōes contábeis anuais, observando-se que a única diferença respeita ao período considerado. Entretanto,

“é evidente que o liquidatário pode elaborar um inventário do ativo e do passivo da sociedade ou verificar aqueles que existam na data da sua entrada em funções, embora isso não lhe seja imposto por lei, nem pelo contrato de sociedade nem por deliberação dos sócios; o liquidatário pode tomar as cautelas que julgue necessárias, para sua proteção, bem como pode adotar os procedimentos de caráter preparatório, que julgue adequados à tarefa de que está incumbido. É também manifesto que, para executar as tarefas de liquidação, ele tem de conhecer todo o ativo e passivo da sociedade".

Efetuado o inventário e a avaliaçāo do acervo patrimonial, constituídas todas as provisōes para enfrentamento das despesas de liquidação, indenizaçōes trabalhistas, tributárias e ainda contingências, o balanço de liquidação pode ser representado como na Figura 2.

3 Ibidem. p. 287. 
ATIVO

Disponibilidades

- Caixa e bancos (conforme valores ajustados)

- Aplicaçōes de liquidez imediata (valor aplicado mais rendimentos)

- Aplicações em ouro (valor de mercado menos despesas de corretagem)

Créditos

- Valores e títulos a receber a curto e longo prazo (pelo valor de face mais renda financeira decorrida, se contratada; valor presente quando forem prefixados)

- Despesas antecipadas (valor do eventual ressarcimento)

- Adiantamentos a fornecedores (valor original ou presente, se negociável)

Estoques

- Estoques vendáveis (pelo valor provável de realização, menos impostos e outras despesas diretas de venda)

- Estoque de imóveis para venda (pelo valor provável de realização menos despesas de corretagem, impostos e de cartório)

- Estoques obsoletos (valor provável de liquidaçăo menos despesas de venda)

Investimentos

- Açōes (cotação de Bolsa de Valores menos despesas de corretagem)

- Empresas controladas e coligadas (valor de realizaçăo do património líquido menos impostos sobre ganhos de capital e eventuais despesas de realização)

Imobilizado

- Imóveis (valor avaliado menos despesas de corretagem e de cartório)

- Máquinas e equipamentos (valor avaliado)

- Móveis, utensílios, ferramentas, equipamentos de informática, softwares etc. (valor avaliado)

- Veículos e direitos de uso linhas telefónicas (valor avaliado)

Obs.: Instalaçōes e benfeitorias em propriedade de terceiros são naturalmente desconsideradas, pois se integram ao imóvel, sem possibilidade de realização. Será oportuna leitura do contrato se houver, o que permitirá ao liquidante, Diferido verificar as condiçōes contratadas.

- Despesas pré-operacionais, despesas com pesquisa e desenvolvimento de produtos (são desconsideradas, salvo se esta última possuir valor realizável)

Ativo Intangivel

- Marcas, patentes; ponto comercial etc. (valor avaliado e com liquidez, ou como forma de pagamento a sócio interessado, menos impostos sobre ganhos de capital)

\section{PASSIVO}

\section{Obrigações}

- Fornecedores de bens e serviços (valor original ou presente, se negociável)

- Trabalhistas correntes (valor original mais encargos, se em mora)

- Fiscais correntes (valor original mais encargos, se em mora)

- Financiamentos (principal e encargos até a data ou valor presente se negociável)

- Outras contas a pagar (valor original ou presente, se negociável)

- Adiantamento de clientes (valor original ou presente, se negociável)

Provisões

- Tributárias e indenizaçōes trabalhistas (calculadas)

- Despesas com liquidação (estimadas)

- Contingências (estimadas)

Resultado de Exercicios Futuros

- Receitas e custos futuros (são transferidos para o PL, afetando provisões para IR) PATRIMÔNIO LIQUIDO PROVÁVEL

- (Ativo - Passivo)

Figura 2 Balanço de liquidaçăo 


\section{CAPÍTULO 4 - DISSOLUÇÃO JUDICIAL DE SOCIEDADES}

A dissolução de sociedade opera-se em duas fases distintas. A primeira compreende a liquidação do patrimônio social; a segunda, a partilha do patrimônio remanescente entre os sócios. Como veremos no Capítulo 7, este tema será relevante em termos doutrinários e operacionais para a apuração de haveres em processo judiciais.

\subsection{CAUSAS}

F. MARTINS aponta as causas provocadoras da dissolução societária assim:

a. a falência da sociedade;

b. a vontade de um dos sócios, se a sociedade for celebrada por tempo indeterminado;

c. a impossibilidade da continuação da sociedade por não poder preencher seu fim social;

d. a incapacidade de alguns dos sócios, julgada por sentença;

e. 0 abuso, a prevaricação, a violação ou a falta de cumprimento das obrigaçōes sociais, ou a fuga de algum dos sócios. ${ }^{1}$

Para o objeto central deste trabalho, tem interesse especial a causa mencionada na letra $b$, a mais corriqueira nos processos de dissolução judicial de sociedades.

1 Fran MARTINS, Curso de direito comercial: empresa comercial, empresários individuais, microempresas, sociedades comerciais, fundo de comércio, p. 222-224. 
A morte de sócio pode ensejar, não necessariamente, a dissolução societária. A jurisprudência pátria, como veremos no Capitulo 5 , tem-se pronunciado pela dissolução apenas parcial da sociedade, operando-se a apuração de haveres em favor dos herdeiros.

\subsection{DISPOSITIVOS LEGAIS}

O Código Comercial de 1850 tratou do tema nos arts. 335 ss. O art. 335 disciplinou as situaçōes fáticas que ensejam a dissolução, assim:

"Art. 335. As sociedades reputam-se dissolvidas:

I. Expirando o prazo ajustado da sua duração;

II. Por quebra da sociedade, ou de qualquer dos sócios;

III. Por mútuo consenso de todos os sócios;

IV. Pela morte de um dos sócios, salvo convenção em contrário a respeito dos que sobreviverem;

V. Por vontade de um dos sócios, sendo a sociedade celebrada por tempo indeterminado."

Já o art. 339 abordou as responsabilidades do sócio que se despede ou é desligado assim:

"Art. 339. O sócio que se despedir antes de dissolvida a sociedade ficará responsável pelas obrigaçöes contraidas e perdas havidas até o momento da despedida. No caso de haver lucros a esse tempo existentes, a sociedade tem direito de reter os fundos e interesses do sócio que se despedir, ou for despedido com causa justificada, até se liquidarem todas as negociaçōes pendentes que houverem sido intentadas antes da despedida."

A constituição de sociedades limitadas foi regulada pelo Decreto $n^{0} 3.708$, de 10 de janeiro de 1919. 
Para o tema objeto deste trabalho, merecem ser destacados dois dispositivos do referido diploma legal: arts. $7^{\circ}$ e 15 .

0 art. $7^{\circ}$ disciplina a exclusão de sócio remisso, inadimplente com as obrigações de pagar o valor de suas quotas.

$\mathrm{O}$ art. 15 disciplina o direito de retirada, originário de divergências quanto a alterações do contrato social assim:

"Art. 15. Assiste aos sócios que divergirem da alteração do contrato social a faculdade de se retirarem da sociedade, obtendo o reembolso da quantia correspondente ao seu capital, na proporção do último balanço aprovado. Ficam, porém, obrigados às prestações correspondentes às quotas respectivas, na parte em que essas prestações forem necessárias para 0 pagamento das obrigações contraidas, até a data do registro definitivo da modificação do estatuto social."

Notemos que a legislação citada não especifica que modelo ou método avaliatório deva ser aplicado. Transfere, implicitamente, para o perito em contabilidade essa incumbência.

Entretanto, é de ser observado que a jurisprudência predominante de nossos Tribunais tem encaminhado a matéria no sentido de que seja apurado o patrimônio liquido das sociedades a valores de mercado, na busca incessante do valor justo dos haveres a ser entregue aos herdeiros e sócios dissidentes ou excluidos, evitando-se o denominado enriquecimento sem causa de uns em detrimento de outros.

Quanto à apuração de haveres pelo último balanço, a Súmula 265, do Supremo Tribunal Federal, veio a modificar o disposto no art. 15 retrocitado, como será destacado no Capitulo 5. 
A dissoluçāo judicial de sociedade, por força do art. $1.218{ }^{2}$ do Código de Processo Civil vigente, é disciplinada pelos arts. 655 a 674, do Código de Processo Civil de 1939.

Têm interesse para este trabalho alguns dispositivos sobre os quais passamos a discorrer.

A dissolução societária está disciplinada pelo art. 655 , verbis:

"Art. 655. A dissolução da sociedade civil, ou mercantil, nos casos previstos em lei ou no contrato social, poderá ser declarada, a requerimento de qualquer interessado, para o fim de ser promovida a liquidação judicial."

A decretação da dissolução e a nomeaçāo de liquidante consta do art. 657 , assim:

"Art. 657. Se o juiz declarar, ou decretar, a dissolução, na mesma sentença nomeará liquidante a pessoa a quem pelo contrato, pelos estatutos, ou pela lei, competir tal função."

As obrigaçōes do liquidante, no que se refere aos propósitos do presente trabalho, foram disciplinadas pelo art. 660 , verbis:

"Ant. 660. O liquidante deverá:

1. levantar o inventário dos bens e fazer o balanço da sociedade, nos 15 (quinze) dias seguintes à nomeação, prazo que o juiz poderá prorrogar por motivo justo;

II. promover a cobrança das dividas ativas e pagar as passivas, certas e exigiveis, reclamando dos sócios, na proporção de suas quotas na empresa, os fundos insuficientes, quando insuficientes os de caixa;

omissus;

V. apresentar, mensalmente, ou sempre que o juiz o determinar, balancete de liquidação;

2 Código de Processo Civil: "Art. 1.218. Continuam em vigor até serem incorporados nas leis especiais os procedimentos regulados pelo Decreto-lei $n^{2} 1.608$, de 18 de setembro de 1939, concernentes: $И I-a ̀$ dissolução e liquidação das sociedades (arts. 655 a 674)." 
VI. propor a forma da divisão, ou partilha, ou do pagamento dos sócios, quando ultimada a liquidação, apresentando o relatório dos atos e operações que houver praticado".

Compete, portanto, ao liquidante realizar o ativo e solver as dividas, apurando eventual saldo monetário remanescente, o qual será partilhado em favor dos sócios.

Entretanto, a sociedade em face da morte, exclusão ou retirada de sócio poderá não se dissolver, permanecendo em atividade, como previsto no art. 668 , assim:

"Art. 668. Se a morte ou a retirada de qualquer dos sócios não causar a dissolução da sociedade, serão apurados exclusivamente os seus haveres fazendo-se o pagamento pelo modo estabelecido no contrato social, ou pelo convencionado, ou, ainda, pelo determinado em sentença."

Os Tribunais têm-se posicionado no sentido de garantir a continuidade, determinando, apenas, a dissolução parcial da sociedade. Embora venha sendo denominada de dissolução parcial, conhece-se pelo menos um posicionamento dissidente desse entendimento majoritário.

ESTRELLA entendia ser imprópria referida expressão, sendo "preferivel enquadrar-se todas as hipóteses de afastamento de sócio, com a sobrevivência da sociedade, no conceito genérico de resilição parcial do contrato social".

Outra possibilidade de dissolução parcial com apuração de haveres surge quando falece sócio de sociedade que não anônima; nesse caso, a matéria é disciplinada pelo parágrafo único do art. 993, Capítulo IX, Do inventário e da partilha, Código de Processo Civil, que assim dispõe:

"Art. 993. Dentro de 20 (vinte) dias, contados da data em que prestou compromisso, fará o inventariante as primeiras declarações, das quais se lavrará termo circunstanciado. No termo, assinado pelo juiz, escrivão e inventariante, serão exarados:

3 Hernani ESTRELLA, Apuraçđo dos haveres de sócio, p. 83. 
IV. a relação completa e individuada de todos os bens do espólio e dos alheios que nele forem encontrados, descrevendo-se:

omissus;

e) os títulos da divida pública, bem como as ações, quotas e títulos de sociedade, mencionando-se-lhes o número, o valor e a data;

Parágrafo único. O juiz determinará que se proceda:

1. ao balanço do estabelecimento, se o autor da herança era comerciante em nome individual;

II. a apuração de haveres, se o autor da herança era sócio de sociedade que não anônima". (Grifo nosso.)

Ordenando a avaliação patrimonial, o parágrafo único do art. 1.003 , do Código de Processo Civil, dispõe:

"Art. 1.003. Findo o prazo do art. 1.000, sem impugnação ou decidida a que houver sido oposta, o juiz nomeará perito para avaliar os bens do espólio, se não houver na comarca avaliador judicial.

Parágrafo único. No caso previsto no art. 993, parágrafo único, o juiz nomeará um contador para levantar o balanço ou apurar os haveres". (Grifo nosso.)

Muito embora a razão da apuração de haveres seja a morte de um dos sócios, a doutrina e a jurisprudência, em face da possibilidade de continuidade, têmse pronunciado considerando tal evento, também, como dissolução societária parcial.

Este é o cerne deste trabalho, ou seja, a apuração de haveres em processos judiciais de dissolução parcial de sociedade. 


\subsection{SOCIEDADES IRREGULARES OU DE FATO}

Sociedades irregulares ou de fato se questionadas em juizo podem também gerar a possibilidade judicial de apuração de haveres; entretanto, o rito processual será o das açōes de conhecimento, usualmente denominadas ações ordinárias.

Reputamos uma sociedade com existência irregular se seus estatutos ou contrato social não tiverem sido levados ao registro de comércio, ou se, com prazo determinado, persistir em tempo posterior, enquanto a sociedade de fato se configura como aquela sem ajuste escrito.

Melhor nos socorrermos de REQUIĀO, que bem aborda a questāo das sociedades irregulares ou de fato.

Assim se posiciona o ilustre jurista:

"Preferimos, todavia, a distinção defendida por Waldemar Ferreira, pela qual os sócios às vezes deixam de reduzir a escrito seu ajuste, e 'a sociedade assim constituida, vive, funciona e prospera. Mas vive de fato. Como sociedade de fato se considera'; e, 'outras vezes, ela se organiza por escrito. Articulam-se os dispositivos da lei social. O contrato, porém, não se arquiva no Registro de Comércio. A sociedade é, por isso, irregular. A nosso ver, com efeito, são mais convincentes essas noções, pois a sociedade que não está documentada, que viceja no mundo fático, se pode chamar de sociedade de fato, provada sua existência através de presunções catalogadas no art. 305 do Código Comercial; ${ }^{4}$ ao passo que a que tendo se

\footnotetext{
4 "Art. 305. Presume-se que existe ou existiu sociedade sempre que alguém exercita atos próprios de sociedade, e que regularmente se nđo costumam praticar sem a qualidade social.

Desta natureza sao especialmente:

1. Negociação promiscua e comum; II. Aquisiçdo, alheação, permutação, ou pagamento comum; III. Se um dos associados se confessa sócio, e os outros o não contradizem por uma forma pública; $I V$. Se duas ou mais pessoas propðem um administrador ou gerente comum; $V$. A dissolução da associaçdo como sociedade; $V$. $O$ emprego de pronome nós ou nosso nas cartas de correspondência, livros, faturas, contas e mais papéis comerciais; VI. O fato de receber ou responder cartas endereçadas ao nome ou firma social; VIII. $O$ uso de marca comum nas fazendas ou volumes; $L X$. $O$ uso de nome com a adiçdo - $e$ companhia.

A responsabilidade dos sócios ocultos é pessoal e solidária, como se fossem sócios ostensivos."
} 
constituido por instrumento escrito, mas não o tenha legalizado com o arquivamento no registro competente, permanece irregular em face da lei." ${ }^{5}$ Se não forem registradas no órgão competente, não possuem personalidade jurídica; entretanto, não perdem sua condição de sociedade comercial e, como tal, podem ser alvo de demanda judicial pelos interessados.

\subsection{DESCONTINUIDADE POR DECRETAÇĀO DE FALÊNCIA}

A falência é a mais dramática situação de descontinuidade societária. É uma das espécies de dissolução judicial de sociedade.

A Lei Falimentar logo em seu art. $1^{\circ}$ carateriza a falência assim:

"Art. $1^{\circ}$ Considera-se falido o comerciante que, sem relevante razão de direito, não paga no vencimento obrigação líquida, constante de título que legitime a ação executiva."

Outras situaçōes que levam à decretação da falência estão especificadas no artigo seguinte:

"Art. $2^{\circ}$ Caracteriza-se, também a falência, se o comerciante:

I. executado, não paga, não deposita a importância, ou não nomeia bens à penhora, dentro do prazo legal;

II. procede a liquidação precipitada, ou lança mão de meios ruinosos ou fraudulentos para realizar pagamentos;

III. convoca credores e lhes propõe dilação, remissão de créditos ou cessão de bens;

IV. realiza ou, por atos inequivocos, tenta realizar, com o fito de retardar pagamentos ou fraudar credores, negócio simulado, ou alienação de parte ou da totalidade do seu ativo a terceiro, credor ou não;

Rubens REQUIÃO, Curso de direito comercial, p. 280. 
$V$. transfere a terceiro o seu estabelecimento sem o consentimento de todos os credores, salvo se ficar com bens suficientes para solver o seu passivo;

VI. dá garantia real a algum credor sem ficar com bens livres e desembaraçados equivalentes às suas dividas, ou tenta essa prática, revelada a intenção por atos inequivocos;

VII. ausentar-se sem deixar representante para administrar o negócio, habilitado com recursos suficientes para pagar os credores; abandona 0 estabelecimento; oculta-se ou tenta ocultar-se, deixando furtivamente o seu domicilio.

Parágrafo único. Consideram-se praticados pelas sociedades os atos dessa natureza provenientes de seus diretores, gerentes ou liquidantes."

É a morte societária por absoluta falta de liquidez.

Procedemos à liquidação forçada dos ativos e ao pagamento do passivo de acordo com a escala de prioridades determinada na lei falimentar.

A administração da massa é da responsabilidade do sindico, que tem, entre outros, o dever de arrecadar e mandar avaliar o acervo patrimonial; procede à elaboração do quadro geral de credores; realiza o ativo e paga o passivo em conformidade com a escala de prioridades.

Obviamente, nessa hipótese, nāo há que se falar em aviamento ou goodwill, pois tudo desmorona, o estabelecimento empresarial é lacrado, as relações trabalhistas cessam, os ativos são vendidos. Enfim, a sociedade é dissolvida, a atividade econômica cessa, o estabelecimento empresarial morre. 


\section{CAPITULO 5 - JURISPRUDÊNCIA EM APURAÇÃO DE HAVERES}

Os dispositivos legais que regulam a dissolução societária e a apuração de haveres, como se observou no Capitulo 4 , não especificam que modelo ou método de apuração de haveres deva ser seguido.

A jurisprudência de nossos tribunais tem determinado alguns caminhos, como veremos na seçăo 5.1; antes, porém, cabe considerar que será interpretada em sua vertente relacionada com a ciência contábil, mesmo porque nosso trabalho não visa abordar os pronunciamentos sob a óptica jurídica.

\subsection{JURISPRUDÊNCIA}

Têm interesse para o que debatemos neste trabalho os pronunciamentos dos tribunais pátrios acerca da conseqüência da dissolução de sociedades no que concerne à apuração de haveres.

Vejamos os pronunciamentos.

Do Egrégio Supremo Tribunal Federal temos a Súmula 265:

"Na apuraçāo de haveres, nāo prevalece o balanço não aprovado pelo sócio falecido ou que se retirou."

Esse pronunciamento tem conseqüências relevantes nos procedimentos avaliatórios judiciais, já que impõe ao perito em contabilidade a necessidade de, inexistindo, proceder ao levantamento de balanço patrimonial para a data-base do evento, que os juristas, apropriadamente, denominam de balanço de determinação.

Estando disponivel o balanço de determinação, ele será objeto de exame pericial minucioso a fim de assegurar a veracidade dos elementos patrimoniais ai 
declarados. Inexistindo, sua elaboração é a tarefa essencial do trabalho pericial em apuraçāo de haveres.

O balanço de determinação será tratado no Capitulo 6 .

\subsection{PESQUISA REALIZADA}

Do Egrégio Superior Tribunal de Justiça, por meio do respectivo site, compulsado o verbete haveres.emen., no dia 29 de julho de 1999, surgiram 50 decisões, das quais, excluídas as ementas fora do objeto da pesquisa, foram selecionadas aquelas cujos pronunciamentos determinam e fixam procedimentos de apuração de haveres em processos judiciais de dissolução de sociedades.

Para melhor apreender o sentido e o espírito da matéria ementada, em determinados momentos socorremo-nos dos conteúdos dos votos exarados pelos Senhores Ministros Relatores.

Observamos nos Venerandos Acórdãos e respectivas Ementas do Egrégio Superior Tribunal de Justiça objeto de nossa pesquisa os caminhos norteadores a serem percorridos na apuração de haveres.

Vejamos as Ementas e seu alcance no campo contábil, as quais estão identificadas pelo número obtido na pesquisa realizada, nāo na ordem que aparece no site, mas naquela que interessa aos objetivos deste trabalho. A data consignada no texto da Ementa refere-se ao dia do julgamento.

Justifica-se termos restringido nossa pesquisa aos pronunciamentos do Egrégio Tribunal Superior de Justiça, à medida que, a partir da entrada em vigor da Constituição Federal de 1988, compete a esse Tribunal Superior pronunciar-se em caráter definitivo sobre o tema apuraçāo de haveres. 


\subsubsection{Documentos fora do objeto da pesquisa}

Dos documentos pesquisados, verificamos que, embora tratem de apuração de haveres, alguns estāo fora do campo específico da pesquisa. Perfilam nesse contexto, 13 pronunciamentos. São eles:

- Documento $n^{0}$ 1, que apreciou e pronunciou-se sobre o compartilhamento de quota social indivisivel, prejudicada a sentença que mandou apurar os haveres, por não requerida expressamente.

- Documento $n^{\circ} 2$, que apreciou matéria relativa à consignação de haveres, recusados pelo interessado.

- Documento $n^{0} 7$, que tratou do registro de alteração do contrato social, relativa à exclusão de sócio deliberada pela maioria.

- Documento ñ 13, que abordou a possibilidade de compensação de valores em processo judicial.

- Documento $n^{\circ} 21$, por tratar de reabertura de prazo em processo de execução de sentença de apuração de haveres.

- Documento $n^{0} 24$, que aborda procedimento trabalhista e apuração de haveres de sócio.

- Documento $n^{\circ} 28$, relativo a Recurso Especial que cuidou de haveres de funcionário publico.

- Documento $n^{0} 32$, relativo a direito a pagamento a funcionário de haveres patrimoniais retroativos.

- Documento $n^{\circ} 38$, que abordou a correção monetária de haveres de funcionário.

- Documento no 39, que negou direito de apuraçăo de haveres de proprietário de quotas não-sócio.

- Documento no 40, que negou direito de apuração de haveres de proprietário de quotas não-sócio. 
- Documento $n^{0} 45$, que cuidou de suspensāo de qualquer alienação de bens sociais, enquanto perdurasse o processamento da apuração de haveres em processo de inventário.

- Documento $n^{0} 46$, que tratou de demissão de associado de cooperativa; negada a apuração de haveres requerida.

\subsection{ALCANCE DAS EMENTAS NO CAMPO CONTÁBIL}

A seguir, são examinadas as Ementas do Superior Tribunal de Justiça naqueles aspectos que provocam e determinam procedimentos contábeis avaliatórios nos processos judiciais que envolvem apuração de haveres.

Buscamos apresentar os resultados da pesquisa por temas relevantes; entretanto, alerta-se que, muitas vezes, os temas interpenetram-se, causando certa dificuldade na classificação adotada.

Enquanto método, partindo-se das mais recentes, apresenta-se, primeiramente, a ementa identificada por seu número de ordem que constava do site; em seguida, sāo oferecidos comentários e observaçōes, tudo permeado, às vezes, com trechos do voto do Ministro Relator, de modo que sejam apreendidos o texto e o contexto decisório.

O texto dos votos dos Senhores Ministros Relatores, quando utilizados, estão transcritos em itálico. 


\subsubsection{Balanço de determinação ${ }^{1}$}

\subsubsection{Documento $n^{\circ} 12$ de 50}

- STJ-RECURSO ESPECIAL. APURAÇĀO DE HAVERES. RECESSO DE SÓCIO. INTERESSE DE AGIR. 1. O FATO DE JÁ TER SIDO FEITA EXTRAJUDICIALMENTE A APURAÇÃO DE HAVERES, E, NA ÉPOCA, TER SIDO O AUTOR NOTIFICADO PARA ACOMPANHÁ-LA, COM INDICAÇÃO DE TÉCNICO, E, AINDA, DE TER SIDO POSTO À SUA DISPOSIÇĀO "O VALOR APURADO PELA SOCIEDADE A TÍTULO DE BALANÇO DE DETERMINAÇÃO", RECUSANDO-SE A ASSINAR O RECIBO DE ENTREGA DE DOCUMENTO, COMO INDICADO NA SENTENÇA, NĀO DESQUALIFICA O SEU INTERESSE EM QUESTIONAR JUDICIALMENTE OS VALORES APURADOS NO DITO BALANÇO DE DETERMINAÇĀO, ESTANDO, DESSE MODO, CONFIGURADO O INTERESSE DE AGIR. 2. A APURAÇÃO FEITA PELOS SOCIOS REMANESCENTES NĀO EXCLUI, HAVENDO DIVERGÉNCIA, A APURAÇĀO JUDICIAL, 3. RECURSO CONHECIDO E PROVIDO. 39-1996. (Grifo nosso.)

Do texto ementado pode-se extrair que, muito embora tenha sido preparado extrajudicialmente, dada oportunidade ao dissidente de acompanhar os levantamentos técnicos, bem como terem sido colocados a sua disposição os haveres com base no balanço de determinação, foi reconhecido o direito de poderem ser questionados judicialmente aqueles apurados privadamente.

Do voto é oportuno destacar que:

"Há, portanto, um direito do sócio retirante de receber os seus haveres, na forma estipulada pelo contrato social, o que sinaliza o seu interesse. $O$ fato de já ter sido feita a apuração de haveres, e, na época, ter sido o autor notificado para acompanhá-la, com a indicação de técnico, e, ainda, ter sido posto à sua disposição to valor apurado pela sociedade a título de balanço

Balanço patrimonial elaborado para a data do evento, no qual os elementos patrimoniais săo avaliados e consignados a valores de mercado. É utilizado para determinar o montante dos haveres do sócio retirante ou falecido. 
de determinação', recusando-se a assinar o recibo de entrega do documento, como indicado na sentença, não desqualifica o seu interesse em questionar judicialmente o valores apurados no dito balanço de determinação.

Omissus.

Se o recorrente considera que o apurado não corresponde ao valor real que deveria receber, feita a apuração por balanço de determinação, é evidente que o autor, ainda que tivesse acompanhado toda a operação, tem interesse de agir, requerendo apuração judicial diante da discordância com o números que foram encontrados, eis que pode vir a ser prejudicado pela elaboração de balanço em desconformidade com a realidade da empresa."

Não se pode olvidar que os sócios remanescentes permanecem com toda a estrutura do negócio, têm todos os elementos da sociedade e interesse em minimizar o valor patrimonial da sociedade e, normalmente, são eles que têm o dever de elaborar o balanço de determinação. Evidentemente, o sócio retirante sempre carrega mágoas, incompreensōes, emoçōes, o que dificulta o processo conciliatório, além do que sempre tenderá a valorizar, às vezes, em demasia, sua quota, até com algum espírito de vingança ou raiva. 0 documento $n^{\circ}-16$, de 28-8-95, tratou da mesma temática.

\subsubsection{Documento $n^{\circ} 37$ de 50}

- STJ - COMERCIAL - EMPRESA CONSTITUÍDA POR SÓCIOS DIVERSOS - DISSOLUÇÃO PARCIAL - CRITÉRIO DE APURAÇÃO DOS HAVERES 1 - NA EMPRESA CONSTITUIDA POR SÓCIOS DIVERSOS, RETIRANTE UM DELES, O CRITÉRIO DE LIQUIDAÇĀO DOS HAVERES, SEGUNDO A DOUTRINA E A JURISPRUDÉNCIA, HÁ DE SER, UTILIZANDO-SE O BALANÇO DE DETERMINAÇĀO, COMO SE TRATASSE DE DISSOLUÇÃO TOTAL. ॥ - PRECEDENTES DO STJ. III - RECURSO NÄO CONHECIDO. 27-9.993. (Grifo nosso.) 
Esse pronunciamento teve origem em Recurso Especial promovido por sócios remanescentes inconformados com V. Acórdão da Décima Primeira Turma Càmara Civil do Tribunal de Justiça de São Paulo.

O Senhor Ministro Relator em seu voto, entre outros aspectos, assim se posicionou:

"Portanto, configurada a dissidência e a dissolução, ainda que parcial, decidiu com acerto o Acórdão, verbis:

'A sobredita dissolução parcial, ademais, está prevista em lei e é disciplinada pelo Código de Processo Civil de 1939, cujo art. 668 dispõe: 'Se a morte ou a retirada de qualquer dos sócios não causar a dissolução da sociedade, serão apurados exclusivamente os seus haveres, fazendo-se o pagamento pelo modo estabelecido no contrato social, ou pelo convencionado, ou ainda, pelo determinado na sentença.'

A dissolução parcial ou dissolução, no caso, não está prevista na cláusula $12^{\circledR}$ (décima segunda), mas, sim, na cláusula 11ª (décima primeira) do contrato social, de forma que não há que se falar, na espécie, na necessidade de notificação, só exigivel em caso de negociação das quotas sociais com terceiros.

O contrato social é a fonte primeira dos direitos e obrigações das partes em uma sociedade de responsabilidade limitada, inclusive no caso do exercicio do direito de retirada, com conseqüente apuração de haveres, desde que não haja ofensa a principios de ordem pública e manifesto desequilibrio de deveres e obrigações.

Claro e certo, de conseguinte, que na apuração de haveres dos sócios retirantes deverá ser observada a norma de pagamento parcelado, ou seja, em 6 (seis) prestaçōes mensais, iguais e sucessivas, com correçāo monetária, depois de apurados em liquidação de sentença, como aliás, pedido na exordial.

De se registrar, contudo, que o balanço especial referido na cláusula 119 (décima primeira) não pode ser utilizado na hipótese vertente, porque não 
traduz em números reais, a participação dos Autores na sociedade, desequilibrando o direito das partes.

Em caso tais, consoante iterativa jurisprudência, inobstante parcial a dissolução, deve haver a apuração real e efetiva dos haveres dos sócios dissidentes, com conhecimento pleno do valor de mercado da universalidade dos bens que compunham o patrimônio da sociedade, na época do fato (alteração do contrato social datada de 12-6-90), utilizando-se para tanto, todos os meios de prova aplicáveis, não se limitando a apuração, pois, a mera perícia contábil.

Esse, aliás, é o entendimento da jurisprudência do Supremo Tribunal Federal, conforme Aresto proferido quando do julgamento do RE $n^{\circ} 89.464$ $S P$, relator designado para lavrar o acórdão Ministro Décio Miranda, cuja ementa consignou:

'Comercial. Dissolução de sociedade limitada. Pedida a dissolução total por sócio dissidente, não é possivel, em principio decretar a dissolução parcial, com simples apuração contábil dos haveres do autor. Admitida que seja a dissolução parcial em atenção à conveniência da preservação do empreendimento, dar-seá ela mediante forma de liquidação que a aproxime da dissolução total. Nesse caso, deve ser assegurada ao sócio retirante situação de igualdade na apuração de haveres, fazendo-se esta com a maior amplitude possivel, com a exata verificação, física e contábil, dos valores do ativo.'

Naquela assentada, ao proferir seu voto, com muita propriedade, asseverou o não menos eminente Ministro Moreira Alves:

'Omissus.

Em se tratando, porém, de dissolução parcial, em que ele se retira sem se utilizar dessa faculdade voluntária, entendo que aqui deverá aplicar-se a regra da dissolução total com referência a ele, isto é, que - como salientou o eminente Ministro Décio Miranda - seja feita, quanto a ele, a avaliação dos bens sociais, para o efeito da retirada da sua quota com base nos valores reais, e não apenas nos valores contábeis.' 
Nesse sentido foi a orientação adotada no precedente desta Colenda Terceira Turma, de minha relatoria, onde, por sua ementa, se consignou:

'Na sociedade constituida por dois sócios, pré-morto ou retirante um deles, o critério de liquidação dos haveres, segundo a doutrina e a jurisprudência, há de ser, utilizando-se o balanço de determinaçāo como se tratasse de dissolução total' (Resp. $n^{\circ}$ 24.554-4 - SP - DJ de 16-11-92)." (Grifo nosso.)

Vários ensinamentos nos traz esse pronunciamento. Surge, de pronto, a distinção entre balanço especial e balanço de determinação. Aquele, elaborado pelos sócios remanescentes, normalmente, consigna valores contábeis, o que provoca discórdia entre os sócios. Este, consigna o acervo patrimonial a valores de mercado.

Outro ensinamento é quanto à forma de reembolso da quota, fixada em conformidade com o contrato social, ou seja, na forma parcelada; entretanto, como veremos em momento posterior, poderá ser determinado o reembolso em parcela única.

Aspecto merecedor de destaque e análise é o que se refere à expressāo "exata verificação, física e contábil, dos valores do ativo", que, aliada à expressão "com conhecimento pleno do valor de mercado da universalidade dos bens que compunham o patrimônio da sociedade, na época do fato", traz consigo determinaçāo jurisprudencial quanto aos procedimentos avaliatórios, por vezes, em determinadas situações de fato, inexeqüiveis sob a óptica pericial contábil.

O comando jurisprudencial, por óbvio, supōe a existência de livros mercantis regularmente escriturados, o que permite a exata verificaçāo contábil de tudo quanto ali consignado. Já a verificação fisica, em termos de existências, carrega em si um óbice, salvo melhor juizo, intransponivel. A apuração de haveres sempre é operacionalizada, na imensa maioria dos casos, muito tempo depois da época do fato. Assim, proceder a inventário físico na data do evento nāo é operacionalizável. Tecnicamente, podemos realizar inventário na data da diligència, fazendo caminho inverso, até a época do fato, recompondo o acervo patrimonial, mediante ajustes periciais extracontábeis. A verificação fisica pode também ser entendida enquanto constatação do estado de conservação dos bens, ou seja, como vistoria. 
No que diz respeito ao valor de mercado da universalidade dos bens, merece interpretação restrita, pois determinados bens, por estarem fora de linha, podem ter sua avaliação a valor de mercado prejudicada, por inexistir cotação. Ou, sob a óptica do custo/benefício, o custo de avaliação de determinado rol de bens pode ser mais oneroso que o benefício perseguido. Nessa matéria, há que haver bom-senso, verificando-se a materialidade e a relevância dos itens patrimoniais.

De qualquer modo a palavra universalidade traz consigo a determinação de que nenhum bem escapa do processo avaliatório, implicando, portanto, para o trabalho pericial, em procedimento preliminar de constatação dessa universalidade, inclusive, quanto aos ativos intangiveis.

Por derradeiro, é de ser registrado que os haveres apurados na data do evento são trazidos para a moeda de poder aquisitivo da época do laudo, mesmo porque a correçāo monetária, segundo remansosa jurisprudência, não agrega valor, apenas mantém o poder de compra original.

\subsubsection{Documento $n^{\circ} 41$ de 50}

- STJ - SOCIEDADE CONSTITUIDA POR DOIS SÓCIOS. SÓCIO PRÉMORTO CRITÉRIO DE LIQUIDAÇĀO DOS HAVERES - CONTINUAÇĀO DA SOCIEDADE 1 - NA SOCIEDADE CONSTITUIDA POR DOIS SOCIOS, PRÉ-MORTO OU RETIRANTE UM DELES, O CRITÉRIO DE LIQUIDAÇĀO DOS HAVERES, SEGUNDO A DOUTRINA E JURISPRUDENNCIA, HÁ DE SER UTILIZANDO-SE O BALANÇO DE DETERMINAÇÃO, COMO SE TRATASSE DE DISSOLUÇÃO TOTAL. TAL MEDIDA SE IMPŌE PORQUE, NA DISSOLUÇÃO PARCIAL, GARANTE-SE AO SÓCIO REMANESCENTE CONTINUAR COM A SOCIEDADE, POR SI, COM FIRMA INDIVIDUAL OU COM ADMISSĀO DE OUTRO SÓCIO. II - RECURSO CONHECIDO E PARCIALMENTE PROVIDO. 6-10-1992. (Grifo nosso.)

No V. Acórdão de origem, ficou assentada dissolução total da sociedade, o que gerou a irresignação do sócio remanescente que enseja o Recurso Especial. 
Do voto em apreço, consta o V. Acórdāo do Tribunal de origem, do qual transcrevemos o trecho final, verbis:

"A apuração de haveres nảo é feita somente através do balanço, mas também com inventário dos bens, nos termos do art. $660^{2}$ do Código de Processo Civil antigo, aplicando-se à partilha entre o sócio remanescente e o Espólio a regra dos arts. 1.772 e seguintes do Código Civil, por força do disposto no art. 1.409 do mesmo Código. Ao contrário do que afirma o apelante, o balanço contábil que ele apresentou foi impugnado, lembrandose aqui que a Súmula $n^{\circ} 265$ do Egrégio Supremo Tribunal Federal, segundo a qual, na apuração de haveres, não prevalece o balanço não aprovado pelo sócio falecido, excluído ou que se retirou."

Na seqüência, do voto consta:

"Todavia, num ponto, discrepa o Julgado do entendimento jurisprudencial predominante, inclusive no STJ.

É no que se refere à dissolução da sociedade.

Nesse caso a dissolução deve ser parcial, posto que, assim, e quando se trate de sociedade instituida por dois sócios, há de se ter prevalente o interesse social.

Dai que pré-morto ou retirante um dos sócios, a sociedade continuará com suas atividades com o sócio remanescente.

Sendo certo que os haveres daquele será apurado mediante balanço de determinação ou levantamento geral, com inventário físico e contábil, o que assegura ao sócio retirante o recebimento do devido." (Grifo nosso.)

Do que se transcreveu, exsurge de forma preponderante que a apuração de haveres se processa mediante a elaboração de balanço de determinação, precedido de inventário físico e contábil. Notemos uma pequena variante semântica. No

O artigo citado (inciso I) determina que o liquidante deverá proceder ao inventário dos bens e elaborar o balanço da sociedade. 
pronunciamento anterior, está consignada verificação física e contábil; neste, inventário físico e contábil.

Pelo contexto decisório, nota-se uma preocupação subjacente de que os livros mercantis possam não espelhar com fidedignidade toda a universalidade dos bens patrimoniais. Por isso, o inventário ou verificação física. De qualquer modo, o inventário traz consigo alguns óbices já expostos anteriormente.

\subsubsection{Critérios de apuração dos haveres}

\subsubsection{Documento $n^{\circ} 9$ de 50}

- STJ - SOCIEDADE POR QUOTAS DE RESPONSABILIDADE LIMITADA. RETIRADA DE SÓCIO. DE ACORDO COM A DECISĀO DA INSTÂNCIA ORDINÁRIA, OS "HAVERES DO APELADO DEVERÃO SER APURADOS EM LIQUIDAÇÃO DE SENTENÇA DE FORMA AMPLA E ATUALIZADA." DECISĀO CORRETA, PORQUANTO OS HAVERES SĀO APURADOS COMO SE DE DISSOLUÇĀO TOTAL SE TRATASSE. 4-8-1997: (Grifo nosso.)

Para apreendermos o sentido e o alcance da Ementa, vejamos um trecho do voto do Ministro Relator:

"Relativamente ao mérito, os recorrentes estão inconformados com a maneira de se apurar os haveres do sócio retirante. Determinou a sentença o seguinte: 'a apuração dos haveres através de balanço especial, visando encontrar os haveres reais, por valor de mercado até a data do pagamento'. E foi confirmada pelo acórdāo, pois, 'é evidente que tais haveres deverão ser apurados com a avaliação dos bens que integram o ativo da sociedade a preço de mercado', conforme determinado na decisão recorrida, sob pena de enriquecimento ilicito dos apelantes, em detrimento dos direitos do apelado." (Grifo nosso.)

Fixa, portanto, a forma de avaliaçāo dos ativos a preço de mercado, ou seja, a valor de realização, a fim de não possibilitar enriquecimento sem causa dos 
sócios remanescentes, como se de dissoluçāo total se tratasse; vale dizer, é tecnicamente necessário ajustar os valores patrimoniais registrados nos livros mercantis, para que reflitam os valores de mercado, gerando com muita freqüência ganhos de capital, obviamente, com repercussões tributárias na própria apuração de haveres, mediante constituição das respectivas provisões.

\subsubsection{Documento $n=26$ de 50}

- STJ - COMERCIAL E PROCESSUAL - DISSOLUÇĀO PARCIAL DE SOCIEDADE POR QUOTAS DE RESPONSABILIDADE LIMITADA. I - A DISSOLUÇĀO PARCIAL DE SOCIEDADE, SEGUNDO A JURISPRUDÊNCIA DO STJ, COM A LIQUIDAÇĀO DOS HAVERES DO SÓCIO RETIRANTE, É CRITÉRIO QUE TANTO GARANTE A APURAÇĀO INTEGRAL DESSES HAVERES, QUANTO PRESERVA A CONTINUIDADE DA ATIVIDADE SOCIAL DA SOCIEDADE. 29-8-1994. (Grifo nosso.)

Esse pronunciamento cuidou mais de determinado aspecto juridico, qual seja, o de que a dissolução parcial da sociedade pode ser requerida por sócio, independente de prévia tentativa amigável, reafirmando a doutrina e jurisprudência do STJ sobre o conteúdo ementado.

\subsubsection{Documento nำ 18 de 50}

- STJ - COMERCIAL. EMPRESA POR QUOTAS. APURAÇÃO DE HAVERES. FIRMOU-SE A JURISPRUDENNCIA DO STJ NO SENTIDO DE QUE A LIQUIDAÇĀO DOS HAVERES DO SÓCIO FALECIDO DEVE TER EM LINHA DE CONTA O JUSTO E REAL VALOR DA PARTICIPAÇÃO SOCIETARIA, COMO SE DISSOLUÇĀO TOTAL SE TRATASSE. 3-5-1994. (Grifo nosso.)

Esse pronunciamento tem interesse por suas próprias peculiaridades, envolvendo apuração de haveres por morte de sócio. 
Para aquilatarmos o alcance do pronunciamento, do voto do Senhor Ministro Relator, vejamos o seguinte trecho:

"Por outro lado, para determinar-se o justo e real valor da participação societária em causa, torna-se mister a produção da prova pericial determinada pelo juízo, não calhando a alegação de contrariedade ao art. $668^{3}$ do Código de Processo Civil de 1939, que se refere à modalidade de pagamento. $O$ art. $15^{4}$ do Decreto $n^{\circ} 3708 / 19$ é inteiramente estranho ao debate.

Tal como expresso na ementa que o eminente Ministro Waldemar Sveiter escreveu para o acórdão desta Turma no Agravo Regimental no Agravo de Instrumento $n^{0}$ 22.352-2-SP, a jurisprudência do STJ consagrou entendimento no sentido de que o critério da apuração de haveres, no caso de sócio-retirante ou pré-morto, há de ser como de dissolução total se tratasse."

O justo e o real valor da participação societária, em face dos pronunciamentos já abordados, exigem que a apuração de haveres deve levar em conta:

a. o valor de mercado dos bens patrimoniais (valor real);

b. o valor justo é aquele capaz de impedir enriquecimento sem causa dos sócios remanescentes em detrimento, no caso, dos herdeiros.

Em momento posterior deste trabalho veremos quais os bens suscetiveis de avaliação e como proceder quanto à avaliação de bens patrimoniais sem cotação de mercado, mas possuidores de valor econômico.

\footnotetext{
Código de Processo Civil de 1939: "Art. 668. Se a morte ou a retirada de qualquer dos sócios ndo causar a dissolução da empresa, serão apurados exclusivamente os seus haveres fazendo-se o pagamento pelo modo estabelecido no contrato social, ou pelo convencionado, ou, ainda, pelo determinado na sentença."

+ Decreto no 3.708, 10-1-1919: "Art. 15. Assiste aos sócios que divergirem da alteração do contrato social a faculdade de se retirarem da empresa, obtendo o reembolso da quantia correspondente ao seu capital, na proporção do último balanço aprovado..."
} 
5.3.3 Reembolso da quota e ganhos de capital

\subsubsection{Documento $n^{\circ} 14$ de 50}

- STJ - SOCIEDADE POR QUOTAS - RETIRADA DE SÓCIOS. APURAÇÃO DE SEUS HAVERES, COMO SE DE DISSOLUÇÃO TOTAL SE TRATASSE, SEM PREJUIZO DA PERMANÉNCIA DA SOCIEDADE. SOCIEDADE - LEGITIMIDADE PARA A CAUSA EMBORA A PRETENSÃO DE RETIRADA DE SÓCIO, ENQUANTO ENVOLVE MODIFICAÇÃO DO CONTRATO, SÓ POSSA SER ATENDIDA PELOS REMANESCENTES, O CERTO É QUE O PAGAMENTO DOS HAVERES FAR-SE-Á COM O PATRIMÔNIO DA SOCIEDADE. JUSTIFICA-SE SUA PRESENÇA NO PROCESSO. 14-1996. (Grifo nOSSO.)

Vejamos alguns trechos do voto vencedor que bem situam o ementado:

"Passa a petição de recurso a sustentar a ilegitimidade da empresa para figurar no processo. Malgrado o brilho com que exposta, a tese não merece ser acolhida. Certo que a pretensão de retirada, enquanto envolve modificação do contrato social, haveria de ser atendida pelos demais sócios e não pela sociedade. Entretanto, julgada procedente a ação, o patrimônio da sociedade, e não o pessoal dos sócios, é que arcará com o pagamento do que for devido aos que se retiram. Justifica-se, pois, sua presença no processo.

Sustentam, mais, os recorrentes que houve decisão extra petita. A sentença, confirmada pelo egrégio Tribunal teria condenado os sócios, que figuraram como réus, ao pagamento dos haveres dos recorridos, consignando o magistrado que, 'se o patrimônio é incindivel e imprescindivel à execução do fim social', caberá aos sócios remanescentes aumentar o capital.

Omissus.

A sentença mencionou realmente que caberia aos sócios restantes aumentar o capital, se não havia possibilidade fática de dividir-se o patrimônio. Não os condenou, entretanto, a fazê-lo nem declarou que 
patrimônio. Não os condenou, entretanto, a fazê-lo nem declarou que houvessem de responder como seus próprios bens, pelo pagamento dos haveres dos dissidentes. Trata-se de observação feita de passagem, sem qualquer conteúdo condenatório. Indicou-se um caminho para a solução do problema, suscitados pelos réus, sem prejuizo de que outro pudesse ser adotado."

Em outro trecho do voto consta que:

"Não se determinou realmente a liquidação da sociedade. A chamada dissolução parcial significa que se haverá de apurar o devido aos sócios que se retiram, como se de dissolução total se tratasse. Constitui critério para estabelecer o valor a ser pago.

A jurisprudência deste Tribunal, em relação ao ponto, é firme. Assim decidiu esta Turma no julgamento do Resp 37702, relatado pelo Ministro Waldemar Zveiter (DJ de 13-12-93):

'COMERCIAL - SOCIEDADE CONSTITUIDA POR SÓCIOS DIVERSOS - dissolução parcial - cRITÉRIO de apuRAÇÃo dos HAVERES.

1. Na empresa constituida por sócios diversos, retirante um deles, o critério de liquidação dos haveres, segundo a doutrina e a jurisprudência, há de ser, utilizando-se o balanço de determinação, como se tratasse de dissolução total. II. Precedentes do STJ. III. Recurso não conhecido.'

No mesmo sentido os julgados no Recurso Especial 49.336 (DJ 17-10-94) e no Agravo Regimental no Agravo de Instrumento 22.235 (DJ de 16-11-92)."

Esse pronunciamento tem o mérito de colocar questão muitas vezes olvidada quando da apuração de haveres, qual seja, os ganhos de capital.

À medida que os haveres são solvidos com o patrimônio da sociedade e como o acervo patrimonial é avaliado a valores de mercado, é recorrente o surgimento de ganhos de capital a serem tributados na pessoa jurídica da sociedade. Portanto, esse pronunciamento afirma, implicitamente, a necessidade técnica de o perito em contabilidade proceder à constituição de provisōes para 
cobertura dos encargos tributários sobre ganhos de capital, deduzindo o quantum apurado do patrimônio liquido da sociedade avalianda.

Não constituidas as provisōes, a sociedade avalianda arcará com todo o ônus tributário, beneficiando, indevidamente, o sócio retirante (dissidente ou excluido) ou os herdeiros do sócio pré-morto, já que os haveres apurados estarão superavaliados, causando descapitalizaçāo indevida da sociedade, em prejuizo dos sócios remanescentes.

A aventada soluçāo de sócios remanescentes aumentarem o capital para fazer frente à liquidaçāo dos haveres dos sócios retirantes, à medida que o patrimônio da sociedade era incindivel e indivisivel, é curiosa em seus aspectos técnicos.

Seria uma forma de gerar liquidez à sociedade por aumento de capital, cuja disponibilidade advinda dos sócios remanescentes seria utilizada para aquisição das quotas do sócio retirante pelo valor avaliado; seria desnecessário reconhecer qualquer ganho de capital na sociedade, permanecendo as quotas em tesouraria. Os sócios remanescentes poderiam: (a) repassar essas quotas para novo sócio; ou (b) adquirirem essas quotas. Não podem reduzir o capital social, por força do contido no art. $8^{\circ}$, Decreto $n^{\circ} 3.708$, de 10 de janeiro de 1919 , mas podem reduzir a quantidade de quotas representativas do capital social, aumentando o respectivo valor unitário.

Talvez solução menos onerosa, desde que existam recursos livres disponiveis, será a sociedade adquirir as quotas dos sócios retirantes, ${ }^{5}$ deixando-as em tesouraria, as quais poderão ser adquiridas, futuramente, pelos sócios remanescentes ou por terceiros que vierem a integrar-se à sociedade.

Vislumbra-se nesse procedimento a possibilidade, em face do valor transacionado, do surgimento de Patrimônio Liquido Negativo originário do nãoreconhecimento dos eventuais ganhos de capital, afetando, eventualmente, os limites de crédito perante fornecedores e instituiçōes financeiras.

5 Decreto $\mathrm{n}^{\circ}$ 3.708, de 10-1-1919: "Art. $8^{\circ}$. É licito às sociedades a que se refere esta lei adquirir quotas liberadas, desde que o façam com fundos disponiveis e sem ofensa do capital estipulado no contrato. $A$ aquisição dar-se-á por acordo dos sócios, ou verificada a exclusão de algum sócio remisso, mantendo-se intato o capital durante o prazo da sociedade." 
REQUIĀO assim se posiciona:

"Os haveres do sócio, uma vez apurados, constituem crédito deste contra a sociedade. $O$ valor das quotas, se Ihe for restituido, importará na diminuição do capital social. Pode, todavia, como já se estudou no nْ 266, supra, a sociedade adquirir essas quotas, bem como os demais sócios, sem alteração do capital social."6

O entendimento de REQUIẢO quanto ao valor de as quotas reembolsadas importarem na diminuiçăo do capital social merece ser comentado, à medida que o eminente jurista entende que

"se o balanço não tiver sido aprovado, se os valores contábeis do ativo, sobretudo do imobilizado, forem desatualizados, de forma a empobrecer indevidamente o sócio retirante, os tribunais têm entendido dever apurar-se esses haveres num balanço de determinação, atualizando-se aquele ativo, de forma a proceder-se a uma justa apuração dos haveres"' ${ }^{7}$

Avaliado o acervo patrimonial a valores de mercado como manda a jurisprudência, os haveres do sócio retirante não serão coincidentes com o valor de sua parcela do capital social consignada nos livros societários. Em outras palavras, - valor das quotas assim avaliadas poderá ser maior que o valor da respectiva participação no capital social, inclusive a parcela correspondente à Reserva de correção monetária se houver. A parcela dos lucros acumulados correspondente poderá, também, ser insuficiente à cobertura do crédito.

Não podemos olvidar que, nos procedimentos judiciais, os ajustes avaliatórios levados a termo pelo expert em contabilidade e que resultam no balanço de determinação são efetuados fora dos livros mercantis e em época posterior ao evento.

Assim, quando a sociedade honrar o crédito perante 0 ex-sócio ou herdeiros, terá que consignar em seus registros contábeis os ganhos de capital reconhecidos e homologados judicialmente, submetendo-os à tributação federal. Só

Rubens REQUIÃO, Curso de direito comercial, v. 1, p. 352.

Ibidem, p. 352. 
assim será possivel reduzir proporcionalmente o patrimônio liquido correspondente ao valor dos haveres pagos pela sociedade. Terá que honrar, ainda, os acréscimos de correção monetária e dos juros fixados em sentença, calculados sobre o montante dos haveres apurados.

TRINDADE FILHO, um dos autores da obra citada na nota de rodapé, discorrendo sobre a utilização do seguro de vida no processo de sucessão em pequenos negócios, por falecimento de sócio, quando sucedem problemas com os herdeiros, diz:

"Assim, surgiu a idéia de se contratar (sic) seguros de vida para todos os sócios dessas pequenas empresas, onde a empresa contratava o seguro e também ela era definida como beneficiária das indenizações em caso de morte de algum dos seus sócios. Ocorrendo o falecimento, a empresa recebia a indenização e a utilizava para aquisição da quota-parte que aquele sócio havia deixado para seus herdeiros, eliminando este sério problema." ${ }^{8}$

Entretanto, tal possibilidade resultava infrutifera, à medida que a indenização passava a integrar o patrimônio liquido da sociedade a ser partilhado.

De qualquer modo, é pertinente observar que os sócios retirantes, dissolvida parcialmente a sociedade, passam os mesmos para a posição de credores da sociedade, nāo tendo nenhuma obrigação de financiar a sociedade.

\footnotetext{
8 Antonio Carlos CORTESE et al., Patrimônio e sucessão: como garantir os herdeiros e os negócios, p. 114.
} 


\subsubsection{Forma de pagamento da quota e goodwill}

\subsubsection{Documento $n^{\circ} 15$ de 50}

- STJ - SOCIEDADE COMERCIAL. DISSOLUÇÃO PARCIAL. I - A AÇÃO DE DISSOLUÇĀo PARCIAL DEVE SER PROMOVIDA PELO SÓCIO RETIRANTE CONTRA A SOCIEDADE E OS SÓCIOS REMANESCENTES, EM LITISCONSÓRCIO NECESSÁRIO. $\|$ DECIDINDO AS INSTÂNCIAS ORDINÁRIAS INEXISTIR PREVISÃO CONTRATUAL PARA A RETIRADA MOTIVADA, APLICA-SE A REGRA DO ART 668 DO CPC/39, EM VIGOR POR FORÇA DO DISPOSTO NO ART. 1.218, VII DO CPCI3, A FIM DE SER EFETUADA A APURAÇĀO DOS HAVERES NA FORMA DETERMINADA NA SENTENÇA, ATRAVÉS DE BALANÇO ESPECIAL E PAGAMENTO EM UMA ÚNICA PARCELA. III - INCLUI-SE O FUNDO DE COMÉRCIO E O FUNDO DE RESERVA INSTITUIDO PELA VONTADE DOS SÓCIOS, ENTRE OS HAVERES A SEREM CONSIDERADOS NO BALANÇO ESPECIAL. 4-1996. (Grifo nosso.)

Esse pronunciamento enseja e coloca questões de muita pertinência no campo técnico. Estamos referindo-nos à determinaçāo de apuraçāo mediante balanço especial, ou balanço de determinação, bem como à ordem de inclusão do fundo de comércio e fundo de reserva (sic). E, por fim, com conseqüencias relevantes para a vida da sociedade, a determinação do pagamento dos haveres em parcela única.

Para bem situar o contexto decisório, é oportuno destacar alguns trechos do voto do Senhor Ministro Relator.

Quanto ao pagamento dos haveres em parcela única, ficou assentado no voto:

"Quanto ao modo de pagamento dos haveres do sócio em dissidio, aplicase a mesma regra: à falta de disposição contratual e de convenção entre as partes, o pagamento será efetuado de acordo com o 'determinado na sentença' (art. 668 do CPC/39, em vigor por força do disposto no art. 1.218, 
VII, do CPC/73). Tendo a sentença determinado que o pagamento fosse feito de uma única vez, pelas razões ali expostas, não encontro nisso ilegalidade."

Quanto aos critérios de avaliação e à inclusão do fundo de comércio e fundo de reserva, do voto consta:

“d) os réus reclamam da imprecisão do acórdão quanto aos critérios objetivos a serem adotados pelo perito para a apuração dos haveres. Essa omissão, porém, não está nos julgados, que se preocuparam em explicitar:

'Cabe destacar que o ativo da sociedade deve ser avaliado por justo preço, sem se importar com a denominação que se possa emprestar à forma de apuração do preço. Relevante consignar que o valor atualizado do bem não será aquele obtido por simples aplicação do indice de correção monetária. Será estabelecido por profissional qualificado, que realizará as diligências sem perder de vista os critérios técnico-cientificos que norteiam a avaliação. Assim o valor do bem não será o decorrente do preço especulativo, mas não podem, também, ser ignoradas as normas de mercado que fixam os preços dos bens (sentença, fls. 207).'

Mais não era preciso dizer, além do que constou do v. acórdão, na parte antes transcrita, para orientar o levantamento dos valores.

e) O fundo de comércio e o fundo de reserva instituido pela vontade dos sócios integram o património da sociedade e, por isso, devem ser considerados na avaliação. Se excluidos, enriqueceriam o patrimônio dos sócios remanescentes, em prejuizo do retirante, que também contribuiu, com a sua quota e participação social, para a formação dos dois fundos.

Os recorrentes demonstraram a existência do dissidio, nesse ponto, mas a argumentação favorável aos recorridos é a mais convincente, pois é inegável a patrimonialidade do fundo de comércio, que a jurisprudência 
tem considerado para a apuração dos haveres dos sócios ou de seus herdeiros." (Grifo nosso.)

Comentando os trechos do voto vencedor, sob a óptica contábil, pode-se observar que as determinações ai contidas são muito claras quanto aos critérios avaliatórios, desprezando os valores contábeis e afirmando os valores de mercado como os determinantes na apuração de haveres.

Determina expressamente a inclusão do fundo de comércio, reconhecendo no mesmo patrimonialidade, e ainda o que é denominado de fundo de reserva, que tecnicamente, poderia ser chamado de reserva de lucros, por força da Lei no 6.404/76. Na verdade, a expressāo fundo de reserva era utilizada, quando em vigor o Decreto $n^{\circ} 2.627,{ }^{9}$ de 26 de setembro de 1940.

Sob a óptica contábil, desnecessária a determinação de incluir as reservas, ou, na terminologia anterior, fundo de reserva; basta determinar a avaliação dos ativos e passivos, a valores de mercado, que do respectivo confronto surge, de pronto, o patrimônio liquido da sociedade avalianda.

No que se refere ao pagamento em parcela única, trata-se na verdade de omissão contratual, a qual foi sanada na sentença. Não obstante tal aspecto, dependendo da parcela patrimonial em jogo, poderá ter alto impacto, podendo até comprometer a própria continuidade societária.

É questão sem qualquer ressonância nos trabalhos periciais contábeis, pois não compete ao perito em contabilidade entrar no mérito daquilo que se debate no processo judicial, salvo se instado pelo magistrado a apresentar estudo relativo ao impacto do pagamento único sobre a estrutura de capitais e nivel de atividade da sociedade avalianda.

\footnotetext{
Decreto no 2627/40: "Art. 130. Dos lucros liquidos verificados far-se-á, antes de qualquer outra, a deduçdo de cinco por cento, para a constituição de um fundo de reserva, destinado a assegurar a integralidade do capital. Essa deduçào deixará de ser obrigatória logo que o fundo de reserva atinja $20 \%$ (vinte por cento) do capital social, que será reintegrado quando sofrer diminuição." (Grifo nosso.) Essa destinação do lucro, com 0 advento da Lei no 6.404/76, passou a denominar-se Reserva legal.
} 


\subsubsection{Documento $n^{\circ} \mathbf{4 3}$ de 50}

- STJ - CIVIL. DISSOLUÇÃo PARCIAL. APURAÇÃO DE HAVERES. FORMA DE PAGAMENTO. VALOR DA CONCESSÃO. INTERPRETAÇĀO DE CLÁUSULAS CONTRATUAIS. 1. NĀO CABE REINTERPRETAR CLÁUSULAS CONTRATUAIS, EM SEDE DE RECURSO ESPECIAL (SÚMULA 05/STJ). 2. NA APURAÇĀO DE HAVERES, PARA O PAGAMENTO A SÓCIO QUE É AFASTADO, SEM EXTINÇĀO DA SOCIEDADE, INCLUI-SE O VALOR DA CONCESSÃO PARA COMERCIALIZAR PRODUTOS EM DETERMINADA ÁREA TERRITORIAL. 4-8-1992. (Grifo nOSSO.)

Esse pronunciamento traz à baila a determinaçāo de considerarmos, entre outros, um dos componentes dos ativos intangiveis da sociedade, no caso, o contrato de concessāo de marca, também conhecido por bandeira.

Para apreendermos o contexto decisório, transcrevemos parte do trecho do Voto da lavra do Senhor Ministro Waldemar Zveiter, verbis:

'Esse segundo aspecto - o da chamada 'bandeira' - foi tormentoso antes do advento da Lei 6.729 , mas ele diz respeito exclusivamente à relação juridica entre o concedente e o concessionário. Esse ponto foi tormentoso, porque se admitia que, em uma ruptura violenta da concessão, esta, antes da existência da Lei - porque assim sustentavam os concedentes -, não havia de integrar fundo de comércio com o valor real, uma vez que esses cessionários usufruiam do próprio poder da marca.

Na verdade, a Lei 6.729 veio regulamentar essa espécie, e hoje não mais se discute ser ou não possivel, porque, em realidade, não se haverá de considerar exclusivamente o detentor da marca como senhor desse valor imponderável, que integra o fundo de comércio, nāo propriamente pela marca, mas pelos serviços que também presta o concessionário. Não é - simples fato da existencia da marca que seleciona determinada clientela que integra um fundo de comércio, senão a própria realização de serviços, tais como o de mecânica, de reparos, de manutenção de veículos, como 
também o bom trato, a aparência da loja, o trato dos vendedores no atendimento aos cliente, a oferta de determinadas vantagens, requisitos e confortos. Todos esses são bens imponderáveis que devem integrar o fundo de comércio e não exclusivamente a marca ou a chamada 'bandeira'.

De sorte que esse valor imponderável é aferivel, e isso, sem dúvida, foi o que se realizou e concedeu a sentença, confirmada pelo acórdão, atribuindo-lhe um valor". (Negrito nosso.)

De nossa parte, cabe dizer tratar-se o contrato de concessão de um ativo intangivel com valor econômico mensurável, considerando, entre outros aspectos, a quota estipulada em confronto com a quota e a margem de comercialização realizadas.

\subsubsection{Reembolso da quota e avaliação de sociedades controladas e coligadas}

\subsubsection{Documento $\mathrm{n}^{\circ} 17$ de 50}

- STJ - COMERCIAL. DISSOLUÇĀO DE SOCIEDADE. TRATANDO-SE DE DISSOLUÇĀO PARCIAL DE SOCIEDADE POR QUOTAS, NĀO SE APLICA O CRITÉRIO ESTABELECIDO NO PARÁGRAFO $1 \%$ DO ART. 45 DA LEI № 6.404, DE $19766^{10}$ QUE É PARA A DETERMINAÇĀO DO VALOR DE REEMBOLSO DAS AÇÕES AO ACIONISTA DISSIDENTE. IMPÖE-SE, EM TAL HIPÓTESE, DETERMINAR O VALOR REAL DAS AÇOEES DE SOCIEDADE ANÔNIMA QUE INTEGRAM O PATRIMÔNIO DA SOCIEDADE POR QUOTAS PARCIALMENTE DISSOLVIDA, NA MEDIDA EM QUE A APURAÇĀO DE HAVERES DEVE SER PROCEDIDA COMO SE DE DISSOLUÇĀO TOTAL SE TRATASSE. 6.61995. (Grifo nosso.)

Esse pronunciamento marca posição, distinguindo apuração de haveres do direito de recesso e reembolso de ações a acionista dissidente, temas juridicamente diferenciados e, por isso, importantes quando da apuração de haveres, envolvendo

10 Lei $\mathrm{n}^{\circ}$ 6.404/76: "Art. 45. O reembolso é a operação pela qual, nos casos previstos em lei. a companhia paga aos acionistas dissidentes de deliberação da assembléia geral o valor de suas açðes." 
sociedade limitada, controladora (holding) de outras sociedades, entre as quais sociedades anônimas.

Vejamos determinado trecho do voto que ilustra a questão:

"Uma coisa é o direito de recesso assegurado ao acionista dissidente, cujo exercicio implica o reembolso por valor pelo menos correspondente ao patrimônio líquido das ações, de acordo com o último balanço aprovado pela assembléia geral, bem outra, entretanto, é a dissolução parcial de sociedade por quotas, caso em que, segundo remansosa jurisprudéncia, a apuração de haveres deve ser procedida como se de dissolução total se tratasse.

Sendo assim, impõe-se determinar o valor real das açōes de sociedade anônima que integram o patrimônio da sociedade por quotas parcialmente dissolvidas, mediante balanço especial, tal como entendeu o $\mathrm{v}$. acórdão recorrido." (Grifo nosso.)

Nessa situação fática, dando cumprimento ao comando jurisprudencial, é de se proceder à avaliação, iniciando-a a partir da base da pirâmide societária, percorrendo caminho de subida, avaliando as sociedades (anônimas ou limitadas) existentes entre a base e a controladora, a valores de mercado, desenvolvendo procedimentos técnicos de equivalência patrimonial que irão refletir-se no balanço de determinação da sociedade avalianda.

Apurar os haveres de sócio retirante ou falecido de sociedade limitada controladora implica, em face do comando jurisprudencial, avaliar todas as sociedades controladas, direta ou indiretamente, a valores de mercado. 


\subsubsection{Documento nำ 29 de 50}

- STJ - SOCIEDADE POR QUOTAS - TRANSFORMAÇÃO EM ANÓNIMA - RETIRADA DE SÓCIO - APURAÇĀO DE HAVERES. DANDO-SE A RETIRADA EXATAMENTE EM RAZÃO DE O SÓCIO DISCORDAR DA TRANSFORMAÇĀO, INCIDEM AS NORMAS QUE CUIDAM DAS EMPRESAS POR QUOTAS E NĀO DAS ANÓNIMAS. DECRETO 3.708/19 - ART. 18 - A APLICAÇĀO DAS REGRAS, PERTINENTES ÀS SOCIEDADES ANÓNIMAS É SUBSIDIÁRIA, DEVENDO AS RELAÇŐES ENTRE OS SÓCIOS SE REGULAR, ANTES PELO CONTRATO SOCIAL. A DETERMINAÇĀO CONSTANTE DO ART. 15 DO DECRETO 3.708, DE QUE A APURAÇĀO SE FARÁ PELO ÚLTIMO BALANÇO APROVADO NĀO IMPEDE QUE, NO CONTRATO, DISPONHAM OS SÓCIOS DE FORMA DIVERSA. NA INTERPRETAÇĀO DOS CONTRATOS SÃO SOBERANAS AS INSTÂNCIAS ORDINÁRIAS, NĀO PODENDO A MATÉRIA SER REVISTA NO ESPECIAL. 9.8-1994. (Grifo nOSSO.)

Esse pronunciamento tem interesse para este trabalho. Se o sócio resistir à transformaçăo de sociedade por quotas em sociedade anônima, aplicam-se as regras que disciplinam a sociedade original.

Consta do voto do Senhor Ministro Relator ser inaplicável apurar os haveres como disposto no art. 15 do Decreto $n^{\circ} 3.708 / 19$, ou seja, pelo último balanço aprovado, já que os sócios, no contrato social, dispuseram de modo diferente. Nesse sentido, veja-se parte do voto, verbis:

"No caso em julgamento, o acórdão recorrido acertadamente afirmou que haveria de ser levantado um balanço especial, porque assim previsto no contrato."

E acrescentou 0 acórdão recorrido:

"Não parece justo e nem consentâneo com as vontades dos sócios, nos contratos referidos, que a sua retirada, prevista contratualmente, se dê por valores meramente escriturais. A convenção, em todos os contratos, de um balanço especial para o caso, ainda que se interpretando no sentido de 
que se trata de um balanço fora do tempo regular previsto no art. $10, \S 4^{\circ}$, do velho Código Comercial, tem sua razão de ser. Pretende-se um balanço atual! Não se vê como esta atualidade não diga respeito a que os valores sejam efetivamente reais ao tempo, ou valores de mercado como postulam os Apelantes.

Devendo a questão resolver-se nos termos em que pactuado, o mais diz com a interpretação do contrato, e nisso são soberanas as instâncias ordinárias.

Vale notar, ainda, que a tendência doutrinária e jurisprudencial é no sentido de assegurar ao sócio, que se retira da sociedade, receber o valor de sua quota com base em apuração de haveres que encontre valores reais e não apenas contábeis. (...) E Requião assinala 'que o juiz ao verificar a desatualização dos valores do balanço tem o arbitrio de determinar que a apuração dos haveres seja efetuada pelos valores reais, e não pelos valores contabilizados' (Curso de direito comercial - Saraiva - 17. ed. $-2^{\circ} \mathrm{v}$. -p. 274)." (Grifo nosso.)

Novamente, deparamo-nos com comando que determina a apuraçāo dos haveres pelos valores de mercado dos componentes patrimoniais.

\subsubsection{Documento $n^{\circ} 34$ de 50}

- STJ - COMERCIAL EMPRESA POR QUOTAS DE RESPONSABILIDADE. TRANSFORMAÇĀO EM EMPRESA ANÔNIMA POR VONTADE DO SÓCIO MAJORITÁRIO. RETIRADA DOS SÓCIOS DISSIDENTES. - DISSOLUÇĀO PARCIAL, COM PAGAMENTO DOS HAVERES TAL COMO SE DE DISSOLUÇĀO TOTAL TRATASSE, EM FACE DAS PECULIARIDADES DO CASO CONCRETO - DECISĀO QUE NĀO IMPLICOU OFENSA AOS ARTS, 20 DO CÓDIGO CIVIL, 291 E 302 DO CÓDIGO COMERCIAL E 668 DO CPC DE 1939. - AUSÉNCIA DE DISSIDIO JURISPRUDENCIAL. 14-12-1993. (Grifo nosso.) 
Trata-se de pronunciamento em Recurso Especial originário do Rio Grande do Sul, no qual dois sócios minoritários, não concordando com a transformação societária, propuseram perante a sociedade e o sócio majoritário ação de cobrança de seus haveres.

A questão veio à instância superior por conta da resistência do sócio majoritário. A matéria foi abordada apenas em seus aspectos jurídicos, entretanto, entende-se oportuna a transcrição da decisão do Tribunal de origem:

"No atinente ao art. 20 do Código Civil, consoante o qual as pessoas juridicas têm existência distinta da dos seus membros, não houve afirmação em contrário, pois o voto condutor justificou, sem arranhão a qualquer comando legal, a legitimidade passiva do sócio majoritário, verbis:

'Precisamente fincado na circunstância é que o sócio remanescente se justifica para não efetuar a apuração dos haveres dos retirantes e, pois, para não atender ao respectivo pagamento.

Ora, se assim é, não há falar-se em regramento do recesso segundo as normas da Lei das Sociedades Anônimas, posto que tal não é a natureza da que fazem parte os Autores e ... [nome do réu]. São eles integrantes, ainda, da sociedade por quotas de responsabilidade limitada, pois jamais anuiram na transformação a despeito das equivocadas referências da inicial e das cartas que antes haviam endereçado ao sócio remanescente.

Omissus.

No que toca à apuração dos haveres, correta a fundamentação da sentença ao determinar a efetuação de balanço especial, com ampla apuração dos valores físicos e contábeis da sociedade, com a pertinente pericia, como se de dissolução total se tratasse e justamente pelas peculiaridades da espécie, em que desponta a circunstância de serem três os componentes da sociedade, dois dos quais são os retirantes. Que se retiram inconformados com a imposição do sócio majoritário a respeito do novo tipo juridico da sociedade. Não é justo que 
- causador do dissenso colha sozinho os frutos produzidos pela sociedade." (Grifo nosso.)

É notório que os Tribunais de Justiça Estaduais vieram ao longo do tempo construindo jurisprudência quanto aos paradigmas avaliatórios. Esse Acórdão retrotranscrito é prova disso.

\subsubsection{Documento $n^{\circ} 11$ de 50}

- STJ - SOCIEDADE ANÔNIMA EXCLUSĀO DE SÓCIO. APURAÇĀO DE HAVERES. HIPÓTESE QUE MAIS SE APROXIMA DO RESGATE QUE DO REEMBOLSO. INEXISTENNCIA DE ILEGALIDADE NO FATO DE DETERMINAR-SE SEJAM OS HAVERES DOS EXCLUIDOS APURADOS MEDIANTE APURAÇÃO DO VALOR REAL DO ATIVO E PASSIVO DA SOCIEDADE. 25.3-1997. (Grifo nosso.)

Trata-se de pronunciamento deveras singular que aborda a apuração de haveres em sociedade anônima, pela exclusão de acionista. Para percebermos as peculariedades do caso em tela, é oportuno verificar alguns trechos do voto do Senhor Ministro Relator, verbis:

"Não se me afigura que a hipótese possa ser assimilada ao reembolso, de que cuida aquela norma, e que se faz em caso de exercicio do direito de recesso. Não se cuida aqui de retirada voluntária do acionista dissidente de deliberação societária, mas de exclusão de sócios. 0 caso antes se assemelha ao resgate. $E$ para esse já decidiu esta Turma não contrariar a lei 'a decisão que, à mingua de disposição estatutária, determinou que o preço tivesse em conta o patrimônio liquido, não simplesmente por sua expressão contábil, mas como apurado, em vista dos valores reais, consoante o mercado' (Resp 63.378, DJ 9-10-1995).

Omissus.

O caso, entretanto, não é de reembolso, que se liga ao direito de recesso. $E$ esse supõe que a retirada do sócio se faça em virtude de sua dissidência de 
deliberação da assembléia, pertinente a alguma das hipóteses previstas em lei. O acionista, em tal caso, elege a solução que the pareça mais adequada. Poderá permanecer na sociedade, malgrado em desacordo com o que foi decidido, ou optar pela saída.

O caso é peculiar. Procedeu-se à exclusão dos sócios que haviam postulado a dissolução da sociedade. A saida foi forçada. Não se discute aqui se isso era ou não juridicamente possivel. Apenas se questiona a respeito do cálculo do valor a ser pago aos excluídos. Ora, como salientado na decisão que julgou o agravo de instrumento, a espécie muito mais se aproxima do resgate, dado seu caráter forçado." (Grifo nosso.)

No caso vertente, o pronunciamento jurisprudencial determinou que a participação societária dos acionistas expulsos fosse avaliada como se apuração de haveres fosse, apurando-se o patrimônio líquido a valores de mercado dos componentes patrimoniais, abandonando-se, portanto, a expressão contábil dos mesmos.

\subsubsection{Perícia contábil em apuração de haveres}

\subsubsection{Documento $n^{\circ} 20$ de 50}

- STJ - AÇÃO DE DISSOLUÇÃO DE SOCIEDADE COMERCIAL. LIQUIDAÇĀO DE SENTENÇA - ACÓRDÃO QUE, NA APURAÇĀO DE HAVERES, ACOLHEU O VALOR ARBITRADO PELO PERITO JUDICIAL. MATÉRIA DE PROVA, INSUSCETIVEL DE REEXAME EM SEDE DE RECURSO ESPECIAL - VALORAÇÃO DE PROVA. CONCEITO PREQUESTIONAMENTO - AGRAVO REGIMENTAL IMPROVIDO. 11-1995. (Grifo nosso)

Esse pronunciamento suscita interesse por abordar a fixação dos haveres por arbitramento pericial, mas sem possibilidade de modificação em sede de recurso especial, em face do ordenamento jurídico pátrio. 
A fixação de valor por meio de arbitramento é procedimento processual de liquidação de sentença, previsto no art. 606, Código de Processo Civil, quando a sentença não determina o valor da condenação.

Por isso, requerida ou determinada a liquidaçăo por arbitramento, o magistrado ${ }^{11}$ procede à nomeaçăo de perito em contabilidade para, por meio do laudo de arbitramento, dar liquidez à sentença.

Cabe aqui trazer para o debate a NBC T 13 - Da Perícia Contábil, aprovada pelo Conselho Federal de Contabilidade, que dispõe o quanto segue:

"o arbitramento é a determinação de valores ou solução de controvérsia por critério técnico".

Trata-se de procedimento pericial contábil de alta responsabilidade técnica, pois compete ao profissional perito definir as premissas e criterios a serem adotados. Referido procedimento năo autoriza ao perito em contabilidade ser arbitrário. Há que justificar, categoricamente, como obteve o valor fixado.

\subsubsection{Atualizaçāo monetária e juros em apuração de haveres}

\subsubsection{Documento $\mathrm{n}^{\circ} \mathbf{1 0}$ de 50}

- STJ - SÓCIO. FALECIMENTO. APURAÇĀO DE HAVERES. LEVANTAMENTO DE TODOS OS VALORES DEVIDOS NÄO SE JUSTIFICANDO REMETER-SE A OUTRO PROCESSO A DECISẢO DE QUESTŌES A ISSO PERTINENTES. INFRAÇÃO DO ART. 458 DO CPC. JUROS. LIQUIDAÇĀO. POSSIBILIDADE DE SEREM INCLUIDOS NA LIQUIDAÇĀO, EMBORA A ELES NĀO SE TENHA FEITO REFERĖNCIA NA SENTENÇA. TERMO INICIAL. OBRIGAÇÃO ILIQQUIDA. NĀO SE TRATANDO DE ILICITO ABSOLUTO, FLUEM DA CITAÇÃO. 15-1997. (Grifo nosso.)

1 Código de Processo Civil de 1973: "Art. 607. Requerida a liquidação por arbitramento, o juiz nomeará o perito e fixará o prazo para a entrega do laudo." 
Esse pronunciamento, no que se refere ao campo contábil, abordou, inicialmente, a inclusão de investimentos de sociedade coligada, não considerada na avaliação, o que ensejou perícia contábil complementar, tendo o Senhor Ministro Relator exposto que "a apuração de haveres não poderia se limitar à empresa de que era sócio o de cujus, devendo estender-se àquelas outras em que tinha ela participação no capital", acrescentando, mais adiante, que "a totalidade dos haveres do espólio seria fixada após a realização da pericia".

Na seqüência, diz:

"Devem-se efetivamente afastar os acréscimos patrimoniais posteriores ao óbito, pois já ficou decidido, preclusivamente, que os valores se reportarão à época em que aquele ocorreu. Entretanto, não pode ficar sem resposta a pretensão de que sejam incluidos todos os bens imóveis, ainda que não constantes de registros contábeis, bem como de que se tenha em conta o valor real e não apenas o correspondente a tais lançamentos."

Esse trecho do voto coloca dois aspectos de relevância na apuraçăo de haveres, quais sejam: (a) as variaçōes patrimoniais posteriores ao evento são desconsideradas; e (b) todos os bens patrimoniais da sociedade, independente de registro contábil, sāo considerados e incluídos no processo avaliatório pericial.

Por isso, em outros pronunciamentos analisados em momentos anteriores, viu-se explicitada a determinação de inventário físico e contábil do acervo patrimonial.

No que se refere à atualização monetária, a questão foi tratada no voto assim:

"Vale, entretanto, salientar a importância de que se proceda à correção. Assim é que, no caso em exame, se nenhum se fizer, seja no periodo anterior, seja no periodo posterior à Lei 6.899/81, o resultado será o de que esse processo inteiro terá redundado em nada, pois nada terá a receber o espólio. Não se corrigindo a importância da condenação, essa corresponderá a bem menos de um centavo, não podendo ser saldada. Todo o acervo representado pelos haveres do sócio falecido, em lugar de 
passar a seus herdeiros, iria integrar, [em] última análise, o dos remanescentes."

O último item enfrentado tratou dos juros, tendo ficado consignado no voto o quanto segue:

"Examino, por fim, o especial que ataca o acórdão, relativo aos declaratórios, na parte em que determinou fossem contados juros a partir da citação.

Não houve, ai, ofensa a coisa julgada. Os juros não haviam sido negados, podendo ser incluidos, já que se trata de acessório. Nesse sentido a Súmula $254^{12}$ do Supremo Tribunal Federal."

Desse pronunciamento colhem-se, em síntese, diretrizes quanto à inclusão, no processo contábil de apuração de haveres, de todo o acervo patrimonial existente à época do evento, inclusive participações societárias em sociedades coligadas, excluidas as variações posteriores à data do evento; os haveres sofrem atualização monetária desde a época do evento, tudo acrescido de juros contados a partir da citação.

\subsubsection{Documento $n^{\circ} 25$ de 50}

- STJ - SOCIEDADE COMERCIAL. APURAÇĀO DE HAVERES DO SÓCIO RETIRANTE, CONDENAÇĀO PELA QUAL RESPONDE O SÓCIO REMANESCENTE. LIQUIDAÇÃO DE SENTENÇA. JUROS DE MORA. ÉPOCA DE FLUENNCIA TRATANDO-SE DE OBRIGAÇĀO ILIQUIDA, CONTAM-SE OS JUROS MORATÓRIOS A PARTIR DA CITAÇÃO INICIAL PARA A AÇĀO. SÚMULA № 163-STF. RECURSO ESPECIAL CONHECIDO, EM PARTE, E PROVIDO. 11-10-1994 (Grifo nosso.)

12 Súmula STF no 254: "Incluem-se os juros moratórios na liquidação, embora omisso o pedido inicial ou a condenação." 
Do voto colhemos, como no pronunciamento anterior, todo o entendimento quanto ao início da fluencia dos juros moratórios em processos que envolvem apuração de haveres. Vejamos alguns trechos:

"Ora, se a obrigação é iliquida, contam-se os juros de mora desde a citação inicial para a ação, computados sobre o capital determinado pela sentença. Omissus.

Eis por que, fixado pela sentença de liquidação o valor pecuniário, os efeitos da mora retrotraem à época inicial da ação."

Portanto, ao perito em contabilidade, quando nomeado na fase de liquidação de sentença para apuração de haveres de sócio retirante, compete, além da fixação dos haveres mediante o balanço de determinação, proceder ao cálculo de juros moratórios como fixado na sentença.

\subsubsection{Outros pronunciamentos}

São apresentadas, a seguir, as ementas restantes que completam todo o universo da jurisprudência do Supremo Tribunal de Justiça sobre apuraçăo de haveres pesquisada, pela ordem das mais recentes para as mais anteriores.

\subsubsection{Supremo Tribunal de Justiça}

\section{Documento $n^{\circ} 3$ de 50}

- STJ - DISSOLUÇÃO DE SOCIEDADE. PAGAMENTO DOS HAVERES DO SÓCIO RETIRANTE. CONTRATO SOCIAL. PRECEDENTES DA CORTE 1 NA LINHA DE PRECEDENTES DA CORTE, "NÃO HÁ RAZÃO PARA NEGAR EFICÁCIA À CLÁUSULA CONTRATUAL QUE ESTABELECEU DEVEREM OS HAVERES DO SOCIO QUE SE RETIRA SER PAGOS EM PARCELAS". 2. RECURSO ESPECIAL CONHECIDO E PROVIDO. 12-5-1998. (Grifo nosso.) 
Documento $n^{\circ} \mathbf{4}$ de 50

- STJ - SOCIEDADE COMERCIAL. DISSOLUÇĀO. MORTE DO SÓCIO. EMBORA CONSTITUIDA POR APENAS DOIS SÓCIOS, E HAVENDO DIVERGÊNCIA ENTRE O SÓCIO REMANESCENTE E OS HERDEIROS DO PRÉ-MORTO, NÃO CABE A EXTINÇÃO DA SOCIEDADE, MAS APENAS A SUA "DISSOLUÇÃO PARCIAL", COM APURAÇÃO DOS HAVERES DEVIDOS AO ESPÓLIO ATRAVÉS DE BALANÇO ESPECIAL. RECURSO CONHECIDO EM PARTE E PARCIALMENTE PROVIDO. 18-12-1997. (Grifo nosso.)

\section{Documento n 5 de 50}

- STJ - EMBARGOS DE DECLARAÇÃO. RECURSO ESPECIAL. DISSOLUÇĀO DE SOCIEDADE. RETIRADA DE SÓCIO. APURAÇĀO DE HAVERES. 1 O ACÓRDÃO EMBARGADO, CUIDANDO DA RETIRADA DO SÓCIO E DA FORMA DE PAGAMENTO, PARCELADA OU DE UMA ÚNICA VEZ, MANTEVE-SE DENTRO DOS LIMITES JURIDICOS DA DEMANDA. 2. CONFERE-SE EFEITO MODIFICATIVO AOS EMBARGOS DE DECLARAÇĀO APENAS QUANDO HOUVER OMISSÃO, CONTRADIÇĀO OU OBSCURIDADE, CUJA SOLUÇÃO DÊ ENSEJO À REFORMA DO ACÓRDÃO EMBARGADO. 3. ATENDIDO O PEDIDO PRINCIPAL DO AUTOR, O NÄO-ACOLHIMENTO DE PEDIDO SECUNDÁRIO NĀO CARACTERIZA A SUCUMBÉNCIA RECIPROCA. 4. EMBARGOS DE DECLARAÇĀO REJEITADOS. 25-11-1997. (Grifo nosso.) 


\section{Documento $n^{\circ} 8$ de 50}

- STJ - DISSOLUÇÃo DE SOCIEDADE. PAGAMENTO dOS HAVERES DO SÓCIO RETIRANTE. CONTRATO SOCIAL. PRECEDENTES DA CORTE. 1. NA LINHA DE PRECEDENTES DA CORTE "NÃO HÁ RAZÄO PARA NEGAR EFICIENNCIA À CLÁUSULA CONTRATUAL QUE ESTABELECEU DEVEREM OS HAVERES DO SOCIO QUE SE RETIRA SER PAGOS EM PARCELAS". 2. RECURSO ESPECIAL CONHECIDO E PROVIDO EM PARTE. 25-11-1997. (Grifo nosso.)

\section{Documento $n^{\circ} 6$ de 50}

- STJ - DIREITOS COMERCIAL E PROCESSUAL CIVIL. DISSOLUÇÃO PARCIAL DE SOCIEDADE MERCANTIL. EXTINÇÃO DA AFFECTIO SOCIETATIS. ${ }^{13}$ NOTIFICAÇĀO PRÉVIA. DISPENSABILIDADE. APRESENTAÇĀO DE CERTIDĀO NEGATIVA DE EXECUTIVO FISCAL. DESCABIMENTO CUMULAÇĀO DE PEDIDOS. DISSOLUÇÃO COM APURAÇÃO DE HAVERES. POSSIBILIDADE. PREVISÃO EXPRESSA. RECURSO DESACOLHIDO. I - É DISPENSÁVEL A NOTIFICAÇĀO PREMONITÓRIA COMO CONDIÇĀO DE PROCEDIBILIDADE DA AÇĀO DE DISSOLUÇĀO PARCIAL DA SOCIEDADE COMERCIAL BASEADA NA EXTINÇÃO DA AFFECTIO SOCIETATIS, INAPLICANDO À ESPÉCIE A NORMA DO ART. 15 DO DEC. 3.708/19. II - NĀO SE EXIGE NAS AÇÕES DE DISSOLUÇÃO PARCIAL DE SOCIEDADE COMERCIAL A APRESENTAÇĀO DE CERTIDĀO NEGATIVA DE EXECUTIVO FISCAL DE QUE TRATA O ART. 3. DO DL 858/69. III - A CUMULAÇĀO DOS PEDIDOS DE DECRETAÇĀO DA DISSOLUÇÃO PARCIAL DA SOCIEDADE COM O DE APURAÇÃO DE HAVERES É JURIDICAMENTE POSSIVEL PORQUE EXPRESSAMENTE PREVISTO EM FORMA ESPECIFICA. 13-10-1997. (Grifo nosso.)

13 Rubens REQUIÃO, op. cit., p. 288: antiga expressão latina que significa a intençāo de se associar em sociedade. 


\section{Documento $n^{\circ} 23$ de 50}

- STJ - INVENTÁRIO. APURAÇĀO DE HAVERES. ACÓRDÃO CARENTE DE FUNDAMENTAÇĀO, NOTADAMENTE POR HAVER SE OMITIDO SOBRE QUESTĀO RELEVANTE SUSCITADA NO RECURSO. AFRONTA AOS ARTS, 165 E 458, 11, DO CPC. RECURSO ESPECIAL CONHECIDO E PROVIDO 21-2-1995.

\section{Documento $n^{\circ} 19$ de 50}

- STJ - SOCIEDADE POR QUOTAS DE RESPONSABILIDADE LIMITADA. APURAÇÃO DE HAVERES. FALECIMENTO DE UM SÓCIO. ACÓRDÃO QUE SE CINGIU AO EXAME DAS PROVAS PRODUZIDAS NO BOJO DOS AUTOS, SENDO INVIÁVEIS OS RECURSOS EM QUE OS RECORRENTES ALEGAM CONTRARIEDADE A DISPOSIÇŌES DO CPC E DA LEI № 6.729/79, QUE DE RESTO NĀO FORAM VENTILADOS (SÜMULA № 7 DO STJ). - VERBA HONORÁRIA QUE OBSERVOU OS PARÂMETROS A QUE ALUDE O ART. 20, PAR. 3\% DO CPC. RECURSOS ESPECIAIS NĀO CONHECIDOS. 104-1995. (Grifo nosSO.)

\section{Documento $n^{\circ} \mathbf{2 7}$ de 50}

- STJ - DISSOLUÇÃo PARCIAL DE SOCIEDADE APURAÇĀo DE HAVERES. PRETENSĀO DO RÉU DE QUE SEJAM CHAMADOS AO PROCESSO OS DEMAIS SÓCIOS 1. IMPOSSIBILIDADE, POR NĀO SER CASO DE LITISCONSÓRCIO NECESSÁRIO ATIVO. 2. QUANDO RECONVEM, O REU PROCEDE EM RELAÇÄO AO AUTOR EXISTENTE; O RÉU PROPÓE RECONVENÇĀO CONTRA QUEM LHE PROPÓS A AÇÃO. 3. HIPÓTESE DE OFENSA AO ART. 47 DO CÓD. DE PR. CIVIL, DONDE CONHECIDO E PROVIDO O RECURSO. 16-8-1994. (Grifo nOSSO.) 
- STJ - SOCIEDADE POR QUOTAS. PRETENSÃO DE DISSOLUÇÃO TOTAL PRETENSÃO DE DISSOLUÇÃO TOTAL E LIQUIDAÇÃO DE SOCIEDADE POR QUOTAS DE RESPONSABILIDADE LIMITADA, POSTULANDO-SE A DISSOLUÇÃO PARCIAL APENAS NA APELAÇĀO INTERPOSTA DA SENTENÇA DE IMPROCEDÊNCIA. EM TAL CONTEXTO, NĀO HÁ DIVISAR NEGATIVA DE VIGÊNCIA AOS ARTS. 128 E 459, DO CPC E, TAMPOUCO, AO ART. 335, V, DO CÓDIGO COMERCIAL, TANTO MAIS QUE RESSALVADA A RETIRADA DO SÓCIO DISSIDENTE, PELOS MEIOS PRÓPRIOS, COM A APURAÇÃO DE HAVERES. DISSIDIO JURISPRUDENCIAL NĀO CARACTERIZADO. 76-1994. (Grifo nosso.)

\section{Documento $n^{\circ} .31$ de 50}

- STJ - SOCIEDADE - SAÍDA DE SÓCIO - NĀO HAVENDO OFENSA A LEI DE ORDEM PÚBLICA NEM SE VISLUMBRANDO HIPÓTESE DE ENRIQUECIMENTO SEM CAUSA, NĀO HÁ RAZĀO PARA NEGAR EFICÁCIA A CLÁUSULA CONTRATUAL QUE ESTABELECEU DEVESSEM OS HAVERES DO SÓCIO QUE SE RETIRA SEREM PAGOS EM PARCELAS APLICAÇÃO DO PRINCÍPIO DA FORÇA OBRIGATÓRIA DOS CONTRATOS E INCIDÊNCIA, ADEMAIS, DO DISPOSTO NOS ARTS. 302,65 E 7 DO CÓDIGO COMERCIAL (DECRETO $3.708 / 19$ - ART. 29) E NO ART. 668 DO CÓDIGO DE PROCESSO CIVIL DE 39, EM VIGOR POR FORÇA DO ART. 1.218 DA VIGENTE LEI PROCESSUAL. CLÁUSULA CONTRATUAL QUE SE JUSTIFICA POR INTERESSAR A CONTINUAÇÃO DA EMPRESA QUE SE PODERIA INVIABILIZAR CASO O PAGAMENTO DO SÓCIO QUE SE RETIRA DEVESSE FAZER-SE INTEGRALMENTE, DE UMA SO VEZ. 138.1994. (Grifo nosso.) 


\section{Documento $n^{\circ} \mathbf{3 0}$ de 50}

- STJ - DIREITO PRIVADO SOCIEDADE. CAPITAL ESTRANGEIRO. DISSOLUÇĀO REQUERIDA POR UM DOS DOIS SÓCIOS OSTENSIVOS. LIQUIDAÇĀO. SINGULARIDADES DA DEMANDA. RECURSO CONHECIDO E PROVIDO 1 - DOUTRINA E JURISPRUDENNCIA (CONFIRA-SE, A PROPÓSITO, DENTRE OUTROS, ESTUDO DO SENHOR MINISTRO WALDEMAR ZVEITER, "IN" 'INFORMATIVO/STJ' VOL. 5, № 2, 1993) VÊM SE ORIENTANDO PELA CONTINUACCĀO DA EMPRESA MESMO QUANDO REQUERIDA A SUA DISSOLUÇĀO POR UM DOS DOIS SÓCIOS QUE A INTEGRAM, DESDE QUE OCORRENTES RAZŌES JUSTIFICADORAS DESSA PERMANÉNCIA, CIRCUNSTÂNCIAS NÃO DESCORTINADAS NA ESPÉCIE. II - TEM-SE RECOMENDADO, POR OUTRO LADO, QUE A APURAÇÃo DE HAVERES, NOS CASOS DE DISSOLUÇĀO, NĀO SE DÊ DE ACORDO COM A SIMPLES PARTICIPAÇÃO NO CAPITAL SOCIAL, RESUMINDO-SE À AFERIÇĀO DAS QUOTAS SOCIAIS, MAS DA FORMA MAIS AMPLA POSSIVEL, NA LINHA DO ENUNCIADO № 265 DA JURISPRUDÊNCIA SUMULADA DO SUPREMO TRIBUNAL FEDERAL, CONSTRUÍDO NA VIGÉNCIA DO SISTEMA CONSTITUCIONAL ANTERIOR. III - NESSA LIQUIDAÇÃO, ADEMAIS, É DE LEVAR-SE EM CONSIDERAÇÃO AFIRMAÇÃO DAS PARTES, SEGUNDO AS QUAIS A EMPRESA SEQUER TERIA INICIADO SUAS ATIVIDADES (AUTOR) E QUE NĀO HAVERIA PATRIMÔNIO A PARTILHAR (RÉU-RECORRIDO): 24-10-1995. (Grifo nosso.) 
- STJ - AÇÃo dE VERIFICAÇÃo dE HAVERES, EM fase dE LIQUIDAÇÃo. PROVA E PREQUESTIONAMENTO. 1. DA PERICIA CONTÁBIL, EM TERMOS DE HIPÓTESES FORMULADAS PELO PERITO, ACOLHIDA PELO ACÓRDĀO UMA DELAS, NĀO CABE REEXAME NA INSTÂNCIA EXCEPCIONAL, A TEOR DA SÚMULA 7, APLICÁVEL AO CASO EM EXAME. 2. NÃO PREVIAMENTE SUSCITADA A QUESTÃO FEDERAL EM TORNO QUE DEPOIS SE TEVE POR VIOLADA, É DE SE TER POR AUSENTE O PREQUESTIONAMENTO. 3. RECURSO ESPECIAL NĀO CONHECIDO. 25-1994. (Grifo nosso.)

\section{Documento $n^{\circ} 35$ de 50}

- STJ - COMERCIAL. PROCESSUAL CIVIL. SOCIEDADE POR AÇŌES. DISSOLUÇÃO. CERCEAMENTO DE PROVAS. DECISÃO ALÉM DO PEDIDO. 1. NĀO CABE ALEGAR CERCEAMENTO DE PROVAS AQUELE QUE VITORIOSO NA DEMANDA, POR ACOLHIDO PEDIDO SUCESSIVAMENTE POSTO NĀO DEVOLVE A QUESTĀO RELACIONADA COM O PRIMEIRO PEDIDO, EM APELAÇĀO. 2. NĀO CONTRARIA AS REGRAS SOBRE OS LIMITES DA LIDE O ACÓRDĀO QUE, ACOLHENDO, PARCIALMENTE, APELAÇĀO DOS VENCIDOS, MODIFICA A FORMA DE RETIRADA DOS HAVERES DOS SÓCIOS DISSIDENTES. 29-11-1993. (Grifo nosso.) 


\section{Documento $\mathrm{n}^{\circ} \mathbf{3 6}$ de 50}

- STJ - COMERCIAL - DISSOLUÇĀO DE SOCIEDADE DE RESPONSABILIDADE LIMITADA EM FACE DA VIOLAÇĀO DO PRINCIPIO DA AFFECTIO SOCIETATIS - QUANTUM DEVIDO AO SÓCIO RETIRANTE - MATÉRIA DE FATO (SÚMULAS №s 05 E 07 STJ). I - NA DISSOLUÇĀO DE SOCIEDADE DE RESPONSABILIDADE LIMITADA, A APURAÇĀO DE HAVERES, NO CASO DE SÓCIO RETIRANTE OU PRÉ-MORTO, OU AINDA POR MOTIVO DA QUEBRA DA AFFECTIO SOCIETATIS, HÁ DE FAZER-SE COMO DE DISSOLUÇÃO TOTAL SE TRATASSE POSTO QUE, SEGUNDO A JURISPRUDÊNCIA DO STJ ESSA LINHA DE ENTENDIMENTO TEM POR ESCOPO PRESERVAR O QUANTUM DEVIDO AO SÓCIO RETIRANTE, QUE DEVE SER MEDIDO COM JUSTIÇA, EVITANDO-SE, DE OUTRO MODO, O LOCUPLETAMENTO INDEVIDO DA SOCIEDADE OU SÓCIOS REMANESCENTES EM DETRIMENTO DOS RETIRANTES. II - MATÉRIA DE FATO NĀO SE REEXAMINA EM SEDE DE ESPECIAL (SÚMULAS №s 05 E 07 - STJ). III - RECURSO NĀO CONHECIDO. 9-111993. (Grifo nosso.)

\section{Documento $\mathrm{n}^{\circ} \mathbf{4 2}$ de 50}

- STJ - PROCESSUAL CIVIL - AGRAVO REGIMENTAL - SÓCIORETIRANTE OU PRÉ-MORTO - APURAÇAOO DOS HAVERES MATÉRIA DE PROVA I - A JURISPRUDÊNCIA DO STJ CONSAGROU ENTENDIMENTO NO SENTIDO DE QUE O CRITÉRIO DA APURAÇÃO DE HAVERES, NO CASO DE SÓCIO-RETIRANTE OU PRÉ-MORTO, HÁ DE SER COMO DE DISSOLUÇĀO TOTAL SE TRATASSE. "I MATÉRIA DE PROVA NĀO SE REEXAMINA NA VIA ESTREITA DO ESPECIAL, NEM ASSIM NO BOJO DE REGIMENTAL. III - AGRAVO IMPROVIDO. 13-10-1992. (Grifo nosso.) 


\section{Documento n- 44 de 50}

- STJ - MEDIDA CAUTELAR INOMINADA INCIDENTAL - EFEITO SUSPENSIVO AO RE - ART. 21, V, PAR. 1 DO ATO REGIMENTAL № 01 DO STJ - NORMA DE REGÉNCIA A ÉPOCA DA INTERPOSIÇĀO DO RECURSO - SOCIEDADE LTDA COMPOSTA DE DOIS SÓCIOS MANDADA DISSOLVER PELO ACÓRDĀO RECORRIDO QUE REFORMOU SENTENÇA DE 1 GRAU DANDO PELA DISSOLUÇÃO PARCIAL DA EMPRESA APURADOS OS HAVERES DO SÓCIO DESAVINDO - RELEVÂNCIA ACOLHIDA PELO STF CARACTERIZADOS O "PERICULUM IN MORA" E O "FUMUS BONI JURIS", DEFERE-SE A CAUTELAR 15-9.1989. (Grifo nosso.)

\section{Documento $n^{\circ} \mathbf{4 7}$ de $\mathbf{5 0}$}

- STJ - COMERCIAL. PROCESSUAL. SOCIEDADE POR QUOTAS. DISSOLUÇĀO. A SOCIEDADE POR QUOTAS DE RESPONSABILIDADE LIMITADA SE DISSOLVE QUANDO, PELA RETIRADA DE SÓCIOS, RESTA APENAS UM DELES, MAS SEM EXTINÇĀO DE EMPRESA, QUE CONTINUA A OPERAR, DURANTE A LIQUIDAÇÃO DE HAVERES DOS SÓCIOS RETIRANTES E PODENDO SER RECOMPOSTA PELA ADMISSĀO DE NOVOS SÓCIOS OU PASSAR A OPERAR COMO FIRMA INDIVIDUAL: 24-1991. (Grifo nosso.) 
- STJ - INVENTÁRIO - QUOTA EM SOCIEDADE POR QUOTAS DE RESPONSABILIDADE LIMITADA - APURAÇÃO DE HAVERES. FAZENDO-SE A APURAÇĀO DE HAVERES NOS PRÓPRIOS AUTOS DO INVENTÁRIO, SEM A PARTICIPAÇĀO DOS SÓCIOS REMANESCENTES, APENAS INTERESSA A HERDEIROS E MEEIRA. TERCEIROS NĀO PODEM DELA VALER-SE COMO SE CONSTITUISSE TITULO LIQUIDO E CERTO. 53-1991. (Grifo nosso.)

\section{Documento $\mathrm{n}^{\circ} \mathbf{5 0}$ de $\mathbf{5 0}$}

- STJ - PROCESSUAL CIVIL - RECURSO ESPECIAL - DISSOLUÇÃO PARCIAL DE SOCIEDADE POR QUOTAS DE RESPONSABILIDADE LIMITADA - LEI № 6.404/76 - ART. 206, "D", C/C ART. 18, DO DECRETO № 3.708/19. I - DISSOLUÇÃO PARCIAL DE SOCIEDADE, GARANTINDO-SE AO SÓCIO REMANESCENTE, QUANDO CONSTITUIDA POR APENAS DOIS SÓCIOS, DENTRO NO PRAZO DE UM ANO, RECOMPOR A EMPRESA, COM ADMISSĀO DE OUTRO SÓCIO QUOTISTA E OU AINDA QUE COMO FIRMA INDIVIDUAL, SOB PENA DA DISSOLUÇĀO DE PLENO DIREITO; ASSEGURANDO-SE AO SÓCIO DISSIDENTE O RECEBIMENTO DOS HAVERES QUE LHE SÃO DEVIDOS. II - INTELIGENNCIA DO ART. 206, ALINEA "D", DA LEI DAS SOCIEDADES ANÓNIMAS, C/C O ART. 18, DO DECRETO №3.708/19. III - CONFIGURADO O DISSIDIO, EIS QUE O ACÓRDĀO RECORRIDO DECIDIU A CONTROVÉRSIA EM DISCREPÂNCIA COM A JURISPRUDÉNCIA FIRMADA NOS TRIBUNAIS, INCLUSIVE NO SUPREMO TRIBUNAL FEDERAL. IV - RECURSO PROVIDO. 12-12-1989. (Grifo nosso.) 


\section{Documento $n^{\circ} 49$ de 50}

- STJ - EXECUÇÃo DE SENTENÇA. LIQUIDAÇÃO. hOMOLOGAÇĀo DE PERÍCIA. NATUREZA DO ATO JUDICIAL. O ATO JUDICIAL QUE DISPÕE SOBRE PERICIA REALIZADA PARA APURAR HAVERES DE SÓCIO EXCLUIDO DA SOCIEDADE, DE ACORDO COM O QUE FICOU RESOLVIDO NO PROCESSO DE CONHECIMENTO, HOMOLOGANDOA CONSEQÜENTEMENTE, É SENTENÇA, APELÁVEL PORTANTO. ART 520, III, DO CÓD. DE PR. CIVIL. RECURSO ESPECIAL CONHECIDO E PROVIDO. 27-9-1990. (Grifo nosso.)

\subsubsection{Tribunais de Justiça}

Como subsídio ao que debatemos neste trabalho, são a seguir colecionados pronunciamentos ementados pelos Tribunais de Justiça do Estado de São Paulo TJSP e do Estado do Paraná - TJPR.

- TJSP - EMPRESA COMERCIAL - APURAÇĀO DE HAVERES DO SÓCIO FALECIDO - OBSERVÂNCIA DO CONTRATO SOCIAL, OU PELO CONVENCIONADO, OU AINDA PELO DETERMINADO EM SENTENÇA - VERBAS REEMBOLSÁVEIS QUE DEVEM ATENDER O VALOR REAL DE MERCADO.

- TJSP - INVENTÁRIO - QUESTÃO DE ALTA INDAGAÇÃO DESCARACTERIZAÇĀO - POLEMICA EM TORNO DE LAUDO PERICIAL SOBRE APURAÇĀO DE HAVERES DE ESPÓLIO QUESTĀO DE FATO FUNDADA EM TRABALHO TÉCNICO QUE, EM REGRA, NĀO PODE SER QUALIFICADO DE "ALTA INDAGAÇĀO" INTELIGÉNCIA DO ART. 984 DO CPC. 
- TJSP - EMPRESA COMERCIAL - COMPOSIÇÃO COM DOIS SÓCIOS MORTE DE UM DELES QUE IMPLICA NA DISSOLUÇÃo DE PLENO DIREITO - FALTA DE ACORDO ENTRE AS PARTES - LIQUIDAÇÃO JUDICIAL DETERMINADA POR SENTENÇA. EMPRESA COMERCIAL DISSOLUÇĀO - LIQUIDAÇĀO JUDICIAL QUE NÃO IMPLICA NO FECHAMENTO DO ESTABELECIMENTO COMERCIAL. EMPRESA COMERCIAL - DISSOLUÇĀO - APURAÇĀO DOS HAVERES DO SÓCIO FALECIDO A SER FEITA ATRAVÉS DE BALANÇO E INVENTÁRIO DOS BENS SOCIETÁRIOS.

- TJSP - EMPRESA POR QUOTAS DE RESPONSABILIDADE LIMITADA - DISSOLUÇÃO - AÇÃO PROPOSTA POR SÓCIO EM FACE DE OUTRO, SEM ENVOLVER TERCEIROS - FALTA DE REGISTRO DO CONTRATO CELEBRADO E CONSUMADO NA JUNTA COMERCIAL QUE NĀO CONSTITUI OBSTÁCULO AO EXERCÍCIO DA DEMANDA SE COMPROVADA A AUSÊNCIA DA "AFFECTIO SOCIETATIS" DISSOLUÇÃO QUE, TODAVIA, NÃO IMPLICA PERDA DO OBJETO DA EMPRESA - HIPÓTESE EM QUE CABERÁ AO SÓCIO REMANESCENTE, QUOTISTA MAJORITÁRIO, ADMITIR NOVO SÓCIO OU TOCAR O NEGÓCIO INDIVIDUALMENTE - NECESSIDADE DA APURAÇĀO DOS HAVERES DO AUTOR - AÇĀO PARCIALMENTE PROCEDENTE. 
- TJSP - SEPARAÇÃO CONSENSUAL - APURAÇÃO DE HAVERES QUE OS SEPARANDOS POSSUEM NAS EMPRESAS DAS QUAIS SÃO ACIONISTAS E QUOTISTA MEDIANTE PERICIA - ADMISSIBILIDADE ANULAÇĀO DO PROCESSO A PARTIR DA SENTENÇA QUE HOMOLOGOU A PARTILHA, NEGANDO A PERICIA AVALIATÓRIA NECESSIDADE DA PERÍCIA ANTE A POSSIBILIDADE DA OCORRÉNCIA DE PREJUIZO.

- TJSP - EMPRESA POR QUOTAS DE RESPONSABILIDADE LIMITADA - EXCLUSÃO DE SÓCIO - FATO QUE NĀO IMPLICA DISSOLUÇĀO DA EMPRESA - APURAÇĀO DOS HAVERES DO SÓCIO EXCLUIDO COM BASE NO VALOR PATRIMONIAL DA EMPRESA, OU SEJA, COM A INCLUSĀO DE TODOS OS BENS - INTELIGÉNCIA DO ART. 335 DO CÓDIGO COMERCIAL.

- TJSP - RECURSO - APELAÇÃO - PRAZO - SUSPENSÃO NO PRIMEIRO DIA PELO OFERECIMENTO DE EMBARGOS DECLARATÓRIOS - LAPSO TEMPORAL INALTERADO - REINICIO DA CONTAGEM A PARTIR DO PRIMEIRO DIA ÚTIL APÓS A PUBLICAÇÃO DA DECISĀO SUSCITADA - PRELIMINAR DE INTEMPESTIVIDADE REPELIDA - EMPRESA COMERCIAL - RESPONSABILIDADE LIMITADA - DISSOLUÇĀO - APURAÇẢO DE HAVERES - REEMBOLSO DA QUANTIA CORRESPONDENTE AO CAPITAL DO SÓCIO RETIRANTE NA PROPORÇĀO DO ÚLTIMO BALANÇO APROVADO INADMISSIBILIDADE - NECESSIDADE DE ADOÇĀO DE CRITÉRIO QUE REFLITA A REAL POSIÇĀO ECONÔMICA DA EMPRESA -SUCUMBÊNCIA RECIPROCA. 
- TJSP - EMPRESA CIVIL - EXCLUSĀO DE SÓCIO - DELIBERAÇÃO EXPRESSA DA MAIORIA POR DESAPARECIMENTO DA "AFFECTIO SOCIETATIS" - HIPÓTESE EM QUE SE OPERA "IPSO JURE". A DISSOLUÇÃO PARCIAL COM SIMULTÂNEA ALTERAÇÃO DO CONTRATO - DECISĀO QUE, AO DETERMINAR A APURAÇĀO DE HAVERES DO SÓCIO EXCLUIDO, DECLARA TAMBÉM A EXTINÇÃO PARCIAL - ADMISSIBILIDADE COMO MERO PROVIMENTO DECLARATÓRIO - PRELIMINAR DE NULIDADE POR JULGAMENTO "ULTRA PETITA" AFASTADA LITISCONSÓRCIO PASSIVO NECESSÁRIO UNITÁRIO - CONTESTAÇĀO APRESENTADA POR UM DOS LITISCONSORTES - APROVEITAMENTO PELOS DEMAIS INADMISSIVEL - HIPÓTESE EM QUE PODE NĀO HAVER PROFUNDA IDENTIDADE NO OBJETO DE DEFESA DOS CO-REUS - REVELIA DESTES DECRETADA NO SANEADOR - DECISÃO NÃO RECORRIDA NO MOMENTO OPORTUNO - PRECLUSĀO OPERADA INAPLICABILIDADE DO ART. 320 , I, DO CPC. EMPRESA CIVIL EXCLUSĀO DE SÓCIO - APURAÇĀO DE HAVERES - REALIZAÇĀO ATRAVÉS DE ARBITRAMENTO - ADMISSIBILIDADE, ANTE A AUSÊNCIA DE REGISTROS E LIVROS CONTÁBEIS.

- TJSP - EMPRESA POR QUOTAS DE RESPONSABILIDADE LIMITADA - DISSOLUÇĀO - LEGITIMIDADE "AD CAUSAM" DA EMPRESA EM AÇÕES DESSA NATUREZA - IRRELEVÂNCIA SE A DISSOLUÇĀO FOR TOTAL OU PARCIAL EMPRESA POR QUOTAS DE RESPONSABILIDADE LIMITADA - DISSOLUÇĀO PARCIAL - FATO EM QUE CONSISTE NA APURAÇĀO E PAGAMENTO DOS HAVERES DO SÓCIO RETIRANTE - EMPRESA QUE TEM CONDIÇŌES DE CONTINUAR OPERANDO. 
- TJSP - EMPRESA COMERCIAL - DISSOLUÇÃO E APURAÇÃo DE HAVERES - PERÍCIAS - QUESITOS FORMULADOS SOBRE SIGILO BANCÁRIO - INDEFERIMENTO - INFORMAÇŌES QUE ENVOLVERĀO TERCEIROS QUE NĀO PARTICIPAM DA RELAÇÃO PROCESSUAL INTELIGÉNCIA E APLICAÇĀO DO ART. 426, I DO CPC.

- TJPR - INVENTÁRIO - ARROLAMENTO - INCIDENTE DE APURAÇĀO DE HAVERES EM EMPRESA - FALTA DE PARTICIPAÇÃO DO MINISTÉRIO PÚBLICO - DESNECESSIDADE - EXISTÊNCIA DE APENAS UM INTERESSADO, ÚNICO HERDEIRO, PESSOA MAIOR E CAPAZ - PRELIMINAR DE NULIDADE AFASTADA - APLICAÇĀO DO PARÁGRAFO ÚNICO DO ART. 993 E DO PARÁGRAFO ÚNICO DO ART. 1.003 DO CPC. INVENTÁRIO - ARROLAMENTO - INCIDENTE DE APURAÇĀO DE HAVERES EM EMPRESA COMERCIAL - SENTENÇA BASEADA EM PROVAS PERICIAIS E LAUDOS IDÔNEOS INEXISTÊNCIA DE OFENSA ÀS CLÁUSULAS CONTRATUAIS.

\subsection{RESULTADOS DA PESQUISA}

Posto isto, tudo considerado, temos como resultado da pesquisa que a apuração de haveres em processos judiciais deve considerar o quanto segue:

a. os haveres são apurados mediante a elaboração de balanço de determinação para a data do evento, como se dissolução total fosse, suportado por inventário físico e contábil, considerando a totalidade do acervo patrimonial;

b. os critérios de apuraçāo de haveres devem considerar a universalidade dos bens patrimoniais tangiveis e intangiveis existentes na data do evento, avaliados pelos respectivos valores de mercado, ou seja, devem ser avaliados a valores de saida; 
c. os eventos patrimoniais posteriores à data do evento não afetam a apuração de haveres;

d. o reembolso da quota é responsabilidade da sociedade, à medida que o sócio retirante passa a ser credor da mesma e dá-se na forma preconizada no contrato, ou na forma fixada pela sentença;

e. os haveres apurados sofrem atualização monetária desde a época do evento e sāo acrescidos de juros moratórios desde a citação.

A jurisprudência pesquisada que resultou nos resultados mencionados é unânime.

Entretanto, persiste questão de fundo, qual seja, como proceder à avaliação como se dissolução total se tratasse, quando a jurisprudência determina a inclusão do goodwill ou aviamento?

Dissolução total é liquidação; em procedimentos de liquidação não há que se falar em goodwill ou aviamento. O fundo de comércio, enquanto universalidade dos bens corpóreos e incorpóreos, no que se refere a estes se extingue. A sinergia dessa universalidade esvai-se, restando tão-somente aqueles ativos tangiveis ou corpóreos e mesmo alguns intangiveis passiveis de realização monetária, como, por exemplo, ponto comercial e marca.

O comando como se dissoluçäo total fosse encaminha o perito em contabilidade para os procedimentos de elaboraçāo do balanço de liquidação, ou seja, os componentes patrimoniais são avaliados por seus valores prováveis de realização. Não há futuro a ser considerado e, conseqüentemente, não haveria goodwill ou aviamento a ser mensurado. Entretanto, não é esse o sentido do comando jurisprudencial, já que determina a inclusão do goodwill ou aviamento.

Mensurar o goodwill pressupōe ou impöe olhar o futuro. Assim, da óptica jurídica, data venia, é contraditório o comando jurisprudencial sob exame, à medida que determina que a apuração de haveres se processe levando em conta a universalidade patrimonial, reconhecendo, inclusive, a patrimonialidade do goodwill e determinando, expressamente, sua inclusão na avaliação. Assim, a nosso ver, os 
Tribunais pátrios haverão de reapreciar a contradição econômica em torno da questão.

Sob a óptica contábil, nenhuma constrição se vislumbra, pois, se a sociedade persiste no tempo, não obstante sua dissolução parcial em relaçăo ao sócio retirante ou pré-morto, estamos diante de uma sociedade em marcha, em continuidade. Temos, portanto, a perspectiva do futuro, condição essencial que possibilita o desenvolvimento de procedimentos avaliatórios aplicáveis à mensuração da existência ou inexistência do goodwill ou aviamento.

A Teoria da Avaliação Patrimonial e do Lucro e até em alguns aspectos a própria doutrina juridica dos comercialistas estudados proporcionam-nos 0 arcabouço teórico e operacional que possibilita aquilatar ou mensurar se determinada sociedade em marcha, em face da composição de seus elementos patrimoniais, tem capacidade de gerar lucros acima do que possa ser considerado normal na data-base da avaliação judicial.

O fenômeno em foco surge da tendência sinergética na qual o valor do conjunto dos elementos patrimoniais pode superar a avaliação econômica individual desses mesmos elementos. Em suma, pode surgir o goodwill ou aviamento resultante da forma como o empresário organiza a exploração de sua atividade econômica que COELHO denomina de sobrevalor. ${ }^{14}$

Esse sobrevalor, sob a óptica contábil, somente pode ser objeto de mensuração, quando em continuidade a sociedade. É o que veremos no Capítulo 7.

it Fábio Ulhoa COELHO, Curso de direito comercial, v. 1, p. 91. 


\section{CAPITULO 6 - PRINCÍPIOS CONTÁBEIS E BALANÇO DE DETERMINAÇĀO}

Neste capítulo, são expostos os princípios contábeis que dão suporte à elaboração das demonstraçōes contábeis quando em marcha as sociedades, em contraponto às determinações judiciais que comandam as avaliaçōes judiciais decorrentes de dissolução parcial de sociedades.

\subsection{PRINCIPIOS CONTÁBEIS}

Todo 0 arcabouço norteador dos Princípios Fundamentais de Contabilidade vigentes está centrado na determinaçāo de diretrizes quanto à avaliação dos ativos e passivos e reconhecimento das mutaçōes patrimoniais, pressupondo a continuidade da sociedade.

As transaçōes da entidade são registradas tempestiva e integralmente no momento de sua realização (principio da oportunidade), pelos valores originais (principio do registro pelo valor origina), aceitando-se para determinados valores originais os efeitos da modificação do poder aquisitivo da moeda nacional (principio da atualização monetária), reconhecendo-se as mutações patrimoniais (receitas e despesas) quando de sua ocorrência (principio da competência) e adotando-se sempre o menor valor para os ativos e o maior para os passivos em face de várias alternativas valorativas equivalentes (principio da prudência).

Portanto, as demonstrações contábeis de sociedade em continuidade de suas atividades refletem valores de entrada por força dos Principios Fundamentais de Contabilidade; as transações são registradas pelos valores das épocas em que sucederam, sempre na senda de que referidos valores são objetivos, documentados. 


\subsection{NORMAS BRASILEIRAS DE CONTABILIDADE}

Preliminarmente, cabe destacar que as Normas Brasileiras de Contabilidade emanadas do Conselho Federal de Contabilidade determinam conduta profissional e procedimentos de natureza técnica a serem observados quando da realização de trabalhos contábeis, entre eles, os de natureza pericial contábil, sempre em consonância com os Princípios Fundamentais de Contabilidade, ${ }^{1}$ sujeitando o profissional que não as observa às penalidades mencionadas nas alineas $c, d e e$, do art. $27^{2}$ do Decreto-lei $n^{0}$ 9295, de 27 de maio de 1946, e, ainda, em face do caso concreto, ao Código de Ética Profissional.

Como vimos no Capitulo 5 , os pronunciamentos dos tribunais determinam que a apuração de haveres, decorrentes de dissoluçāo parcial de sociedade, concretiza-se, avaliando-se os elementos patrimoniais pelos valores de mercado e na forma mais ampla possivel, considerando-se, inclusive, o goodwill ou aviamento, enfim, o já mencionado sobrevalor.

Considerando que a dissolução parcial de sociedade é decisão judicial que visa preservar a continuidade societária, que provoca como consequeencia técnica avaliar entidade em funcionamento, como compatibilizar as diretrizes profissionais e técnicas com o comando judicial?

A resposta a essa indagação vamos encontrá-la na NBC-T-4 - DA AVALIAÇĀO PATRIMONIAL, mais especificamente em seu item 4.1.8, verbis:

1 Resolução CFC no 750/93, de 29 de dezembro de 1993: “Art. I² As Normas Brasileiras de Contabilidade estabelecem regras de conduta profissional e procedimentos técnicos a serem observados quando da realização dos trabalhos previstos na Resolução CFC n 560/83, de 28-10-1983, em consonância com os Principios Fundamentais de Contabilidade."

2 "Art. 27. As penalidades aplicáveis por infração do exercicio legal da profissão serão:

c) multa de RS.... a RS.... aos profissionais e de RS... a RS... às firmas, empresas, associaçzes, companhias e empresas, quando se tratar de infração de dispositivos näo mencionados nas alineas precedentes ou para os quais nđo haja indicaçđo de penalidade especial:

d) suspensão do exercicio da profissão aos profissionais que dentro do âmbito de sua atuação, e no que se referir à parte técnica, forem responsáveis por qualquer falsidade de documentos que assinarem e pelas irregularidades de escrituração praticadas no sentido de fraudar as rendas públicas:

e) suspensđo do exercicio da profissão, pelo prazo de seis meses a um ano, ao profissional que demonstrar incapacidade técnica no desempenho de suas funçzes, a critério do Conselho Regional de Contabilidade, a que estiver sujeito, facultada, porém, ao interessado, a mais ampla defesa por si ou pelo Sindicato a que pertencer." 
"4.1.8 Quando, concretamente, a lei dispuser diferentemente desta norma, o profissional deve observar a ordem legal, em seu trabalho".

As decisões judiciais são comandos a serem obedecidos pelos peritos em contabilidade e, à vista do dispositivo retro, superada está eventual ofensa aos Princípios Fundamentais de Contabilidade e às Normas Brasileiras de Contabilidade. Isto não quer dizer olvidar totalmente os Princípios e Normas de Contabilidade, muito pelo contrário.

Independente da Norma Contábil, desde longa data a legislação pátria já determinava procedimentos técnicos de contabilidade. Nesse sentido, vejamos o Código Comercial de 1850 (arts. 10 a 14) e o Decreto-lei no 2.627, de 26 de setembro de 1940 (arts. 129 a 136).

Como vimos, os comandos judiciais determinam que a avaliação dos elementos patrimoniais considere os valores de mercado, em substituição aos valores contábeis e seja reconhecido no processo avaliatório o goodwill, impropriamente denominado de fundo de comércio nos pronunciamentos judiciais. Entendemos ser impróprio utilizar a citada expressão que representa o todo para determinar a inclusão de uma parte do fundo empresarial, ${ }^{3}$ ou seja, o goodwill.

Da NBC-T-4 exsurgem dois comandos avaliatórios extremamente importantes nos trabalhos periciais: valor de mercado e valor presente.

Do item 4.1.6 consta:

"Valor de mercado é o preço a vista praticado, deduzido das despesas de realização e da margem de lucro. As avaliações feitas pelo valor de mercado devem ter como base transação mais recente, cotação em bolsa e outras evidências disponiveis e confiáveis."

Valor presente, item 4.1.7 da Norma citada, é entendido como:

"Aquele que expressa o montante ajustado em forma do tempo a transcorrer entre as datas da operação e do vencimento, de crédito ou obrigação de financiamento ou de outra transação usual da entidade, mediante dedução

3 A expressão fundo empresarial, segundo Fábio Ulhoa COELHO, condiz mais com a realidade econômica atual do que a expressão fundo de comércio. 
dos encargos financeiros respectivos, com base na taxa contratada ou na taxa média de encargos financeiros praticada pelo mercado."

Doutrinariamente, estamos diante de avaliação patrimonial a valores de saida, no caso, a valores de mercado.

\subsection{AVALIAÇÃO PATRIMONIAL EM PROCESSOS JUDICIAIS}

A descontinuidade é sempre lembrada nas obras e artigos técnicos de forma passageira. É apenas anunciada, sem grandes digressões. Pouca literatura há disponivel. A ênfase doutrinária e literária está voltada para as sociedades em continuidade. São essas que têm o dever de informar, freqüentemente, os usuários da informação contábil e o fazem por meio de relatórios e demonstrações próprias.

Entretanto, deparamos com determinados usuários que demandam informações contábeis na descontinuidade total ou parcial, ou seja, na liquidaçăo ou dissolução parcial societária.

São usuários dos laudos periciais contábeis de apuração de haveres os magistrados que determinam a apuração de haveres, e, conseqüentemente, terão que apreciar e homologá-los; são os sócios dissidentes e respectivos advogados, os quais, por meio de seus assistentes técnicos, se pronunciarão sobre os valores ai apurados consignados; são os herdeiros de sócios falecidos e respectivos advogados, interessados na parcela patrimonial que thes cabe; são os sócios remanescentes e a própria sociedade, em face da viabilidade da continuação do negócio e do processo avaliatório pericial e suas implicações financeiras.

Reconhecemos que são tipos muito especiais de usuários, já que precisam de informação contábil em situações conflituosas ou tristes.

De qualquer modo, são usuários da informação contábil. Por isso, há que fornecê-la, de forma clara, correta e competente.

Como é óbvio, a informação contábil disponivel nas sociedades em continuidade nāo permitem suprir as necessidades dos usuários mencionados. Sāo 
informações que levam em consideração a avaliação patrimonial a valores de entrada.

Por isso, é necessário proceder a ajustes técnicos e avaliatórios nas demonstrações contábeis usuais para refletirem com propriedade toda a real dimensão patrimonial. É o que abordaremos a seguir.

\subsubsection{Avaliação dos itens monetários}

São usualmente classificados como itens monetários as disponibilidades, os créditos e as obrigaçōes, ou seja, valores a receber e a pagar liquidáveis com numerário.

Enquanto roteiro avaliatório, a NBC-T-4 é muito rica nos procedimentos técnicos a serem observados. $A$ análise a seguir segue de perto os ensinamentos da citada norma.

\section{- Disponibilidades}

As disponibilidades em moeda corrente correspondem ao seu próprio valor na data-base da avaliação; as disponibilidades em moeda estrangeira são avaliadas pela taxa de câmbio (venda) correspondente, vigente na data da avaliação; as aplicações financeiras de liquidez imediata são mensuradas pelo valor original aplicado, acrescidas dos rendimentos proporcionais obtidos até a data-base; eventuais aplicações em ouro, como ativo financeiro, devem ser avaliadas por seu valor de mercado, considerando-se, em nosso entender, como redutor, as despesas de corretagem.

Alertamos para o fato de eventual saldo de caixa desproporcional ao existente em bancos. Tal saldo deve merecer análise aprofundada, visto que pode não representar efetivamente numerário.

Despesas, retiradas, vales e outros, por falta de comprovaçāo idônea, permanecem na conta, o que ensejará ajustes no patrimônio líquido, ou, conforme o caso, em contas de ativo. 


\section{- Créditos}

Os direitos, títulos de crédito e quaisquer outros créditos mercantis, financeiros e aqueles prefixados são avaliados a valor presente na data-base, considerando, ainda, conforme o caso, os ajustes relativos a atualizaçāo monetária, variação cambial (taxa de câmbio de venda) e outros ajustes contratuais, excluindose do cálculo a valor presente, por óbvio, os direitos ou títulos já vencidos na data da avaliação. Nessa hipótese, havendo avença de encargos por inadimplência, estes são calculados até a data-base, procedendo-se ao respectivo ajuste no patrimônio líquido.

Os créditos com sociedades coligadas, controladas ou de associadas originários de transações mercantis são avaliados pela forma anterior; os demais são ajustados conforme as condiçōes avençadas. Nesse sentido, é relevante, preliminarmente, proceder à segregação dos créditos de natureza mercantil daqueles de natureza financeira, possibilitando avaliação adequada em função da natureza e origem dos créditos.

Investimentos temporários, por força do comando jurisprudencial, são avaliados por seu valor de mercado, ou, inexistindo cotação de mercado disponivel ou de difícil obtenção, pelo custo de aquisiçăo, acrescido de atualizaçăo monetária, juros e outros rendimentos auferidos, conforme a espécie da aplicação.

As provisões para perdas, ou riscos de crédito ou de liquidação duvidosa são consideradas pela análise concreta das perdas havidas. Por isso, é necessário, do ponto de vista pericial, examinar o comportamento do contas a receber após a data-base, a fim de constatar os créditos efetivamente não recebidos. Tal procedimento é plenamente operacionalizável, levando em conta que o trabalho pericial normalmente acontece algum tempo após a data-base.

Eventuais despesas antecipadas consignadas no ativo são baixadas e transferidas como ajuste redutor do patrimônio liquido, em função do tempo decorrido até a data-base da avaliação, já que é assumida no processo avaliatório a continuidade da sociedade. 


\section{- Obrigações}

As obrigaçōes com valor nominal prefixado e com prazo de pagamento após a data-base sāo ajustadas a valor presente. São excluidas do ajuste a valor presente, evidentemente, as vencidas. Săo consideradas pelo valor de face, acrescidas dos encargos de inadimplência já decorridos, provocando referido custo um ajuste redutor do patrimônio líquido.

As demais obrigaçōes por vencer e respectivos encargos, conhecidos ou calculáveis, são consideradas pelo valor atualizado até a data da avaliação, enquanto aquelas em moeda estrangeira, considerando os encargos proporcionais até à data, são convertidas em valor da moeda corrente, à taxa de câmbio (compra) da data da avaliação.

\section{- Provisões correntes}

São examinadas as existentes e realizados os ajustes técnicos necessários a fim de que reflitam com propriedade as responsabilidades até a data-base. Nesse item, inscrevem-se as provisōes para cobertura de férias, $13^{\circ}$ salário e encargos previdenciários e do fundo de garantia por tempo de serviço correspondentes.

Efetuados todos os ajustes técnicos com efeitos no resultado econômico do periodo e apurando-se lucro tributável sobre esse valor, são calculadas e reconhecidas as provisōes tributárias correspondentes, as quais são reportadas na demonstração de resultado do periodo e no correspondente balanço patrimonial.

Efetuados todos os ajustes avaliatórios e observando-se ganhos de capital, sobre esses ganhos são calculadas as respectivas provisões tributárias, que são reportadas no balanço de determinação.

\subsubsection{Avaliação doș itens não monetários}

São considerados itens não monetários os estoques e o permanente, composto pelos investimentos permanentes, imobilizado, diferido e resultados de exercícios futuros. 


\section{- Estoques}

Os estoques, que compreendem produtos acabados e em elaboração, serviços em andamento, mercadorias, matérias-primas e outros materiais e componentes, são avaliados pelos respectivos valores de mercado, observado o comentário a seguir.

As mercadorias, os produtos acabados, os semi-acabados e os serviços em andamento são avaliados pelo preço de venda a vista e seu equivalente (semiacabados e serviços em andamento), sancionados pelo mercado em transações realizadas próximas (antes ou após) à data-base, deduzido o valor das despesas de realização.

As matérias-primas e outros materiais e componentes são avaliados pelo valor de mercado de entrada vigente na data-base, já que referido valor corresponde ao valor de realização.

Os estoques obsoletos ou inserviveis são avaliados pelo valor líquido de realização e aqueles sem possibilidade de venda são baixados.

Os estoques de animais e de produtos agrícolas e extrativos são avaliados pelo valor de mercado vigente na data da avaliação, deduzido das despesas de realização e da margem de lucro.

Proceder à avaliação dos estoques de forma competente pressupõe trabalho pericial preliminar de qualificação dos estoques em vendáveis, obsoletos e invendáveis.

\section{- Investimentos permanentes}

As participaçōes societárias em sociedades controladas e coligadas são avaliadas pelo respectivo valor de mercado do patrimônio líquido na data-base, procedendo-se a sua avaliação pelos mesmos preceitos expostos neste capitulo, para, em seguida, operar-se a integração das variaçōes patrimoniais pelo método da equivalência patrimonial, tudo devidamente reportado no balanço de determinação. 
Havendo provisões para perdas no valor dos investimentos, ou ágio registrados, referidos valores, em confronto com o valor investido e o obtido no processo avaliatório, serão eliminados ou ajustados até o limite da avaliação, acarretando ajustes na substância patrimonial da sociedade avalianda.

\section{- Imobilizado}

Como regra geral, os componentes do imobilizado săo avaliados a preço de mercado, por força do ordenamento jurisprudencial.

A avaliação de determinados componentes deste grupo de ativo, em processo judiciais, requer a realização de pericia avaliatória de engenharia, já que os peritos engenheiros têm a competência legal e técnica para tal. Trata-se de área de conhecimento de domínio dos citados profissionais. Referidas avaliações, no caso de imóveis, levam em consideração, entre outros aspectos, a idade da construção, os materiais utilizados, a localização, o estado de conservaçāo, os serviços públicos disponiveis no local, os quocientes de aproveitamento da área.

É o caso de terrenos urbanos, edifícios, imóveis em construção, estoque de imóveis para venda, propriedades rurais, plantaçōes de culturas permanentes, instalaçōes e maquinários industriais comerciais e rurais, e equipamentos eletrônicos, que são avaliados a valores de mercado.

O perito em contabilidade, ao elaborar seu laudo pericial contábil de apuração de haveres, louva-se nesses laudos avaliatórios de engenharia para proceder aos ajustes necessários de modo que reflitam os valores de mercado desses componentes do imobilizado. $O$ ajuste técnico avaliatório corresponderá à diferença observada entre o valor de mercado e o valor contábil, líquido de depreciação.

Direitos de uso de linhas telefônicas e veículos são avaliados pelos valores de mercado da épóca do evento, valendo-se o perito em contabilidade de publicaçōes próprias e de informaçōes de sociedades especializadas. 


\section{- Diferido}

Os componentes do ativo diferido, segundo a NBC-T-4

"são avaliados ao custo de aplicação, atualizado monetariamente, deduzido das respectivas amortizações, calculadas com base no período em que serão auferidos os beneficios deles decorrentes a partir do inicio da operação normal. A baixa do valor aplicado deve ser registrada quando cessarem os empreendimentos que integravam, ou restar comprovado que estes não produzirão resultados suficientes para amortizá-los".

Assumindo-se que a dissolução parcial enseja a avaliação patrimonial como se em continuidade da sociedade, a regra geral é considerar os valores aplicados em ativos diferidos sem potencial de geração de resultados como ajuste do patrimônio líquido.

Entretanto, o tema, por envolver certa gama de investimentos, alguns gerando frutos, outros nảo, merece atenção pericial para que seja identificada a natureza dos recursos aplicados, especialmente aqueles relativos a pesquisa e desenvolvimento de processos ou produtos, que podem possuir valor econômico, ou seja, têm capacidade gerar lucros futuros. Nesse sentido, permanecem no ativo por aquele valor. A regra geral será: são ativos com capacidade de geração de lucros futuros, portanto, com valor económico? Se positiva a resposta, permanecem no ativo, pelo respectivo valor econômico.

De qualquer modo, no caso de incerteza ou dificuldade em mensurar os beneficios futuros e respectivo valor, a baixa é o caminho, como determinado na norma.

Enquanto síntese do processo avaliatório do ativo, não podemos olvidar a lição de IUDícIBUS, verbis:

"1. o ativo deve ser considerado à luz da sua propriedade elou à luz de sua posse e controle; normalmente as duas condições virão juntas;

2. precisa estar incluido no ativo, em seu bojo, algum direito especifico a benefícios futuros (por exemplo, a proteção à cobertura de sinistro, 
como direito em contraprestação ao prêmio de seguro pago pela empresa) ou, em sentido mais amplo, o elemento precisa apresentar uma potencialidade de serviços futuros (fluxos de caixa futuros) para a entidade;

3. o direito precisa ser exclusivo da entidade; por exemplo, o direito de transportar a mercadoria da entidade por uma via expressa, embora benéfico, não é ativo, pois é geral, não sendo exclusivo da entidade". ${ }^{4}$

\section{- Resultados de exercícios futuros}

Trata-se de item patrimonial em que são registrados lucros ainda não gantios, como, por exemplo, aluguéis recebidos antecipadamente, sem qualquer cláusula que obrigue à respectiva devolução.

No trabalho pericial, é oportuno verificar as origens dos valores aí consignados $e$ as respectivas condiçōes contratuais. Qualquer hipótese de devolução encaminha esse item para o passivo, como se adiantamento de clientes fosse; em caso contrário, é recomendado considerá-lo no patrimônio líquido.

\subsubsection{Contingências}

As contingências passivas conhecidas, originárias de obrigaçōes trabalhistas, previdenciárias, fiscais, contratuais, comerciais ou operacionais e de pleitos administrativos e judiciais, são consideradas e avaliadas por seu valor estimado e consignadas no balanço de determinação, reduzindo o patrimônio líquido.

Esse procedimento avaliatório é baseado nas informaçōes dos advogados da sociedade avalianda e nas possibilidades de êxito ou fracasso das demandas.

Não pode ser olvidada a existência de eventuais contingências ativas, aquelas nas quais a sociedade avalianda é autora. Da mesma forma, são avaliadas as possibilidades de êxito ou fracasso, consignando-se no balanço de determinação

4 Sérgio de IUDÍCIBUS, Teoria da contabilidade, p. 94. 
- valor estimado dos direitos reclamados e o respectivo ajuste positivo no patrimônio líquido.

\subsubsection{Goodwill}

A avaliação do goodwill não adquirido, que a jurisprudência vem denominando de fundo de comércio, equivocadamente como já alertado em momento anterior, é tema de alta indagação doutrinária e operacional, tanto no mundo contábil quanto no jurídico a ser abordado no próximo capítulo.

Havendo goodwill adquirido registrado nos livros sob a forma de ágio, esse ativo será objeto de reavaliação, revendo-se sua concretude em termos de realização futura, ou seja, é preciso verificar na data-base da avaliação se as razões econômicas que ditaram seu valor de origem persistem ao tempo da avaliação judicial.

\subsection{Balanço de determinação}

O balanço de determinação, denominação cunhada por OSMIDA INOCCENTE, ${ }^{5}$ tem por finalidade determinar o valor das quotas a ser reembolsado ao sócio desligado ou aos herdeiros do sócio pré-morto.

Pela elaboração dessa demonstração contábil, o perito em contabilidade bușca a situação patrimonial da sociedade a valores de mercado em determinado momento da vida societária, caraterizado pela dissidência, exclusāo ou morte de um dos sócios.

Como vimos em momento anterior, a jurisprudência pátria tem-se pronunciado, determinando que a apuração de haveres deve ser a mais ampla possivel, mediante inventário físico e contábil de todos os elementos patrimoniais, apuração do valor real do ativo e passivo da sociedade a preços de mercado, inclusive, o goodwill ou aviamento.

s Citado por Hernani ESTRELLA, Apuração dos haveres de sócio, p. 144. 
O balanço de determinação será composto e organizado como vemos na Figura 3. 


\section{ATIVO}

\section{Disponibilidades}

- Caixa e bancos (conforme saldos ajustados)

- Aplicaçðes de liquidez imediata (valor aplicado mais rendimentos)

- Aplicaçð̄es em ouro (valor de mercado menos despesas de corretagem)

Créditos

- Valores e titulos a receber a curto e longo prazo (valor de face trazido a valor presente, acrescido, se for o caso, da renda financeira contratada)

- Despesas antecipadas (pelo valor a apropriar, após a data do evento)

- Adiantamentos a fornecedores (reconhecer eventual ganho monetário)

Estoques

- Estoques vendáveis (preço de venda a vista, deduzido das despesas e da margem de lucro - se mercado organizado - para mercadorias, produtos acabados; produtos semi-elaborados e serviços em andamento: por preços a vista equivalentes ao estado de acabamento; matérias-primas e materiais e componentes: preço a vista de aquisição)

- Estoque de imóveis para venda (valor de realizaçăo, deduzido de despesas de corretagem)

- Estoques obsoletos (valor provável de liquidaçåo)

Investimentos

- Ações de companhias abertas (cotação de Bolsa de Valores)

- Empresas controladas e coligadas (valor do patrimônio líquido a valores de mercado das sociedades controladas ou coligadas)

Imobilizado

- Imóveis (valor do laudo pericial de engenharia menos despesas de corretagem)

- Máquinas e equipamentos (laudo pericial de engenharia, se material)

- Móveis, utensílios, fertamentas, softwares, equipamentos de informática etc. (valor de mercado; considerada a sua materialidade: valor líquido contábil)

- Veiculos e direitos de uso de linhas telefônicas (valor de mercado)

Diferido

- Despesas pré-operacionais, despesas com pesquisa e desenvolvimento de produtos (valor econômico provável)

Ativo intangivel

- Marcas, patentes, ponto comercial, concessões etc. (cálculo pericial contábil)

- Goodwill (cálculo pericial contábil do sobrevalor)

\section{PASSIVO}

\section{Obrigações}

- Fornecedores de bens e serviços (valor de face trazido a valor presente)

- Adiantamento de clientes (reconhecer eventual perda monetária)

- Trabalhistas correntes (pelo valor original, com encargos até a data)

- Provisões trabalhistas correntes (valor original, com encargos até a data)

- Fiscais correntes (valor original, com encargos até a data)

- Financiamentos (principal e encargos até a data)

- Outras contas a pagar (valor original e/ou valor presente)

Provisōes

- Provisర́es tributárias: ganhos de capital (cálculo pericial contábil)

- Contingências trabalhistas, tributárias, comerciais (cálculo pericial contábil)

\section{PATRIMÔNIO LIQQUIDO (VALOR DA SOCIEDADE)}

- (Ativo - Passivo) 
No campo juridico, fala-se em fundo de comércio, com significado bem diferente do que seja goodwill. Eles sāo utilizados, muitas vezes, equivocadamente, como sinônimos, o que pode confundir o leitor menos avisado.

Fundo de comércio é tema jurídico vinculado ao estabelecimento empresarial (comercial, industrial ou agrícola) e relacionado com a proteção dos credores, tema que nāo faz parte do objeto deste trabalho. Neste capitulo, é abordado o goodwill ou aviamento enquanto parte ou parcela integrante do fundo de comércio. Buscamos apreender se a sociedade avalianda tem capacidade de gerar lucros acima do que pode ser considerado normal, ou como argumentam juristas ilustres, se a sociedade tem capacidade de gerar sobrevalor.

\subsection{ALGUMAS DEFINIÇŌES}

AUTUORI, citando Felipe dos Santos, diz:

"O fundo comercial, industrial, agricola ou ainda individual é a soma dos elementos corpóreos e incorpóreos que o constituem, ou que se the agregaram, durante sua existência juridica ou social, em certo local ou em determinado tempo. São elementos desse gênero: mercadorias, instalações, móveis e utensilios, direito de arrendamento total ou parcial, do respectivo local (imóveis ou simplesmente terras), freguesia, nome comercial, insignia, marcas de fábrica ou de comércio, patentes de invenção, modelos de utilidades e o acervo de dividas ativas e passivas, as plantações e benfeitorias do solo, passiveis de aproveitamento comercial, e tudo, enfim, o 
que se incluir na universalidade de valores da propriedade comercial, industrial, agricola e individual." 1

Assim posto, fundo de comércio significa o valor de toda a sociedade, incluindo o goodwill, ou aviamento.

O termo, no campo jurídico, semelhante a goodwill é o denominado aviamento.

Os comercialistas, entre eles, REQUIĀO ${ }^{2}$ e F. MARTINS ${ }^{3}$ vinculam a expressão fundo de comércio à de estabelecimento comercial.

Sāo os elementos corpóreos e incorpóreos criativamente empregados pelo comerciante no exercicio de sua atividade mercantil para atrair clientes que constituem o fundo de comércio, o qual "possui um valor patrimonial que é incorporado pelo comerciante e que pode ser realizado em dinheiro",4 ou nas palavras de REQUIĀO "é o instrumento da atividade do empresário".

F. MARTINS ${ }^{6}$ destaca como elementos incorpóreos do fundo de comércio ou estabelecimento comercial, a propriedade comercial, nome comercial (firma ou a denominação), acessórios do nome comercial (titulo do estabelecimento, expressōes ou sinais de propaganda), propriedade industrial (patentes de invenção, patentes dos modelos de utilidade e dos desenhos e modelos industriais, garantias de uso das marcas de indústria, de comércio e de serviços) e a propriedade imaterial (aviamento e freguesia).

Por outro lado, o autor citado considera como elementos corpóreos os bens móveis (entre eles, as mercadorias em estoque) e os imóveis utilizados no exercicio da atividade mercantil.

REQUIẢO tem entendimento diferente quanto a considerar os imóveis como elemento corpóreo do estabelecimento, assim se expressando:

Luiz AUTUORI, Fundo de comércio, p. 30.

Rubens REQUIÃO, Curso de direito comercial, v. 1, p.197 ss.

Fran MARTINS, Curso de direito comercial: empresa comercial, empresários individuais, microempresas, sociedades comerciais, fundo de comércio, p. 325 ss.

Ibidem, p. 329.

Rubens REQUIÃO, Ibidem, p. 197.

Fran MARTINS, Ibidem, p. 332. 
"Ora, se consideramos o estabelecimento, na sua unidade, uma coisa móvel, claro está, desde logo, que o elemento imóvel não o pode constituir. É preciso, e é de bom aviso aqui frisar, que não se deve confundir fundo de comércio com patrimônio. O fundo de comércio não constitui todo o patrimônio, mas é parte ou parcela do patrimônio do empresário. A empresa, que é o exercício da atividade organizada pelo empresário, conta com vários outros elementos patrimoniais, por este organizados, para a produção ou troca de bens ou serviços que não integram o estabelecimento comercial. O imóvel pode ser elemento da empresa, mas não o é do fundo de comércio."7

COELHO amplia a noção de estabelecimento, denominando-o de empresarial, mais compatível, a nosso ver, com a realidade dos negócios da economia moderna.

Conceitua estabelecimento empresarial como:

"o conjunto de bens que o empresário reúne para exploração de sua atividade econômica. Compreende os bens indispensáveis ou úteis ao desenvolvimento da empresa, como mercadorias em estoque, máquinas, veículos, marca e outros sinais distintivos, tecnologia etc.",

acrescentando que,

"ao organizar o estabelecimento, o empresário agrega aos bens reunidos um sobrevalor. Isto é, enquanto esses bens permanecem articulados em função da empresa, o conjunto alcança, no mercado, um valor superior à simples soma de cada um deles em separado".

Com base nessa conceituação, o autor em foco chega, a nosso ver, à noção contábil de goodwill não adquirido, verbis:

"O valor agregado ao estabelecimento é referido, no meio empresarial, pela locução inglesa goodwill of a trade, ou simplesmente goodwill. No meio juridico, adota-se ora a expressão 'fundo de comércio' (derivada do francês

\footnotetext{
${ }^{7}$ Rubens REQUIĀO, op. cit., v. 1, p. 208.

${ }^{8}$ Fábio Ulhoa COELHO, Curso de direito comercial, v. 1, p. 91.

9 Ibidem, p. 91.
} 
fonds de commerce, e cuja tradução mais ajustada seria, na verdade, 'fundos de comércio'), ora 'aviamento' (do italiano aviamento), para designar o sobrevalor nascido da atividade organizacional do empresário. Prefiro falar em 'fundo de empresa', tendo em vista que o mesmo fato econômico e suas repercussões juridicas se verificam na organização de estabelecimento de qualquer atividade empresarial. Registro que não é correto tomar por sinônimos 'estabelecimento empresarial' e 'fundo de empresa'. Este é atributo daquele; não são, portanto, a mesma coisa. Precise-se: 0 estabelecimento empresarial é o conjunto de bens que o empresário reúne para explorar uma atividade econômica, e o fundo de empresa é o valor agregado ao referido conjunto, em razão da mesma atividade." ${ }^{10}$

Continuando com COELHO, diz o eminente jurista existirem nove teorias diferentes quanto à natureza do estabelecimento, mas entende suficiente evidenciar três pontos essenciais:

“1o estabelecimento empresarial não é sujeito de direito;

$2^{\circ}$ o estabelecimento empresarial é uma coisa;

3ํ 0 estabelecimento empresarial integra o patrimônio da empresa empresária",

e arremata com o seguinte trecho em destaque:

"O estabelecimento empresarial não pode ser confundido com a empresa empresária (sujeito de direito), nem com a empresa (atividade econômica). Empresa é a atividade econômica desenvolvida no estabelecimento, e não se confunde com o complexo de bens nele reunidos. Assim, 0 estabelecimento empresarial pode ser alienado, onerado, arrestado ou penhorado, mas a empresa não." 11

Integram, portanto, o estabelecimento os chamados elementos imateriais, tais como: patentes de invenção, de modelo de utilidade, registro de desenho

10 Ibidem, p. 93.

1 Ibidem. p. 94-9j. 
industrial, marca registrada, nome empresarial, título de estabelecimento, ponto comercial.

COELHO, ao contrário de outros festejados juristas, não considera o aviamento como elemento incorpóreo do estabelecimento.

É de entendimento que o aviamento ou fundo de empresa (para o autor, palavras sinônimas) "é um atributo da empresa, não um bem de propriedade do empresário". ${ }^{12}$

Descarateriza, também a clientela como elemento imaterial do estabelecimento, à medida em que o empresário não é dono do conjunto de pessoas que a formam.

REQUIĀO tem posição mais conciliadora quanto ao posicionamento do aviamento e da clientela.

Săo suas as seguintes palavras:

"Não tomamos posição radical nessa controvérsia. Pensamos que o aviamento, bem como a clientela, tanto podem ser considerados, cada um de per si, como elemento direto da empresa, ou como do estabelecimento comercial. Sabemos que a empresa é a atividade do empresário organizada para o fim de produção ou troca de bens ou serviços; e o estabelecimento é um dos elementos da empresa, precisamente o instrumento da atividade do empresário. Saber se o aviamento, como a clientela, se integram diretamente como elemento da empresa ou se constituem um elemento imaterial do fundo de comércio, não é questão de alta relevância." ${ }^{13}$

Merecem respeito tais posicionamentos; todavia, năo abordam questão fundamental, qual seja, a de que são esses atributos que proporcionam à sociedade avalianda determinados beneficios que se materializam em seu nivel de rentabilidade. O nome, a marca, a clientela, a localização geram beneficios sob a forma de lucros diferenciados, que em qualquer processo avaliatório são sempre considerados.

13 Rubens REQUIÃO, op. cit., v. 1. p. 235-236. 
É óbvio que o empresário não pode arvorar-se em dono de sua clientela, mas é ele que, racionalmente, dispõe os elementos constitutivos de seu negócio de modo a colher os benefícios que aquela the proporciona pelo consumo de seus produtos e serviços. Isto é o quanto basta para se considerar a patrimonialidade desses elementos, independente do debate quanto ao posicionamento da clientela e do aviamento.

Se tais elementos intangiveis têm o condāo de gerar benefícios sob a forma de lucros acima do que pode ser considerado normal, são resultados econômicos pertencentes à sociedade avalianda, distribuiveis, portanto, aos titulares do capital.

REQUIÃO arremata seu entendimento, assim:

"Sendo um fato evidente que a empresa constitui uma atividade organizada contendo vários elementos, ou o estabelecimento comercial vários bens, o valor decorrente desse complexo, é maior do que a soma dos elementos isolados. Essa mais valia constitui, precisamente, o que o direito denomina de aviamento"; em sintese: "aviamento é a aptidão da empresa de produzir lucros, decorrente da qualidade e da melhor perfeição de sua organização". ${ }^{14}$

Entretanto, por óbvio, a atividade mercantil pressupõe a geração de lucros, senão a sociedade fenece. Na verdade, há que se qualificar ou diferenciar tal aptidão, pois qualquer investidor racional somente estará disposto a pagar determinada quantia pelo goodwill ou aviamento se este possuir aptidāo de gerar lucros acima de outro empreendimento semelhante em termos de retorno sobre o investimento; em outras palavras, nenhum empreendedor estará disposto a desembolsar um sobrevalor para obter o mesmo fluxo de lucros futuros.

Como se viu no Capitulo 2, a taxa de juros è o mecanismo que permite a compra e venda de fluxos de renda futuros a valor presente.

Para o perito em contabilidade atuante nos meios forenses, como perito judicial nomeado por juizes, ou como assistente técnico indicado pelas partes, é de extrema relevância saber o significado preciso desses termos (fundo de comércio e

14 Ibidem, p. 236-237. 
aviamento, que neste trabalho é assumido como goodwill), quando atua em processos judiciais em que são determinadas avaliaçōes de sociedades, para efeito de apuração de haveres, a favor de sócios dissidentes ou excluídos, bem assim em favor de herdeiros de sócio falecido.

No que nos toca, os tratadistas contábeis, sem nenhum desmerecimento dos ilustres juristas, enfrentam o goodwill de forma bem mais ampla.

\subsection{CLASSIFICAÇÃO DO GOODWILL}

E. MARTINS, louvando-se em vários autores, apresenta várias classificaçōes quanto à origem do goodwill assim:

- Classificação de PATON e PATON, JR. ${ }^{15}$

"Goodwill comercial - Aquele que aparece em função dos seguintes fatores:

a) serviços colaterais, como equipe cortês de vendedores, entregas convenientes, facilidade de crédito, dependências apropriadas para serviço de manutenção etc.;

b) qualidade do produto em relação ao preço;

c) atitude e hábito do consumidor como fruto de nome comercial e marca tornados proeminentes em função de propaganda persistente;

d) em casos especiais, a localização do estabelecimento e a qualidade e imagem do distribuidor.

Goodwill industrial - 0 que surge em função de altos salários, baixo turnover de empregados, oportunidades internas satisfatórias para acesso às posições hierárquicas superiores, serviço médico, sistema de segurança adequado etc., desde que tais fatores contribuam para a boa imagem da sociedade e também para a redução do custo unitário de produção (devido

is Eliseu MARTINS, Contribuição ao estudo do ativo intangivel, p. 73-74. 
à eficiência de uma força de trabalho operando nessas condições). Dessa forma, um valor (Goodwill) é adicionado à sociedade.

Goodwill financeiro - Aquele derivado da atitude de investidores, fontes de financiamento e de crédito (para capital em dinheiro, bens ou serviços). Existindo essas condições em caráter bastante favorável, possui a firma sólida situação para cumprir suas obrigações e manter sua imagem, ou, então, obter recursos financeiros que the permitam aquisições de matériaprima ou mercadorias em melhores termos e preços.

Goodwill político - O obtido em função de boas relações com o Governo. Esse fator, segundo os autores citados, tem crescido em importância, o que parece ser verdade em muitos paises. Reconhecem também a dificuldade de se efetuar essa própria classificação e admitem a quase impossibilidade prática de se atribuir o todo do Goodwill a cada um dos fatores que o provocam."

\section{- Classificaçāo de CONYNGTON ${ }^{16}$}

Goodwill comercial - Aquele criado independentemente das pessoas proprietárias ou administradoras da sociedade, ou seja, o criado em função única e exclusivamente da firma como um todo. Abrangeria parte dos quatro grupos já citados anteriormente, englobando em cada um deles o que não recebeu influência pessoal dos proprietários ou gerentes.

Goodwill pessoal - Exatamente aquele que surge em função de uma os várias pessoas que integram a sociedade, sendo ela(s) proprietária(s) ou administradora(s). Corresponde, mais ou menos, ao complemento do Goodwill comercial.

Goodwill profissional - O desenvolvido por uma classe profissional (normalmente liberal) que acaba por criar uma imagem que a distingue 0 suficiente dentro da sociedade, a fim de the proporcionar condições de alta remuneração. Cita o caso dos médicos, advogados (no princípio do século principalmente), contadores (em alguns paises) etc.

16 Ibidem, p. 74-75. 
Goodwill evanescente - $O$ Goodwill que tem uma vida muito limitada, pois as circunstâncias que o suportam são de curta duração, como é caso característico de certos produtos que a moda cria; podem ser de qualquer natureza: jogos (como boliche, em alguns lugares, vestuário (botas, por exemplo), lugares públicos (boates) etc.

Goodwill de nome ou marca comercial - Aquele que independe do produto, pois concorrentes o fabricam com as mesmas caracteristicas, e que só pode ser ocasionado pela imagem do nome da empresa que o produz ou da marca sob o qual é comerciado."

Cita, ainda, CATLETT e OLSON, ${ }^{17}$ para os quais os fatores responsáveis pelo aparecimento do goodwill são:

- "administração superior;

- organização ou gerente de venda proeminente;

- fraqueza na administração do competidor;

- propaganda eficaz;

- processo secretos de fabricação;

- boas relações com os empregados;

- crédito proeminente como resultado de uma sólida reputação;

- excelente treinamento para os empregados;

- alta posição perante a comunidade conseguida através de ações filantrópicas e participação em atividades cívicas por parte dos administradores da sociedade;

- desenvolvimento desfavorável nas operações do competidor;

- associações favoráveis com outra sociedade;

- localização estratégica;

- descoberta de talentos ou recursos;

17 Ibidem, p. 75-76. 
- condições favoráveis com relação ao impostos;

- legislação favorável."

O goodwill não adquirido, enquanto valor econômico, não é reconhecido nos livros das sociedades; entretanto, quando adquirido, ele o é. Esse continua sendo um dos temas mais polêmicos no seio da Contabilidade.

\subsection{ASPECTOS POLÊMICOS DA MENSURAÇÃO DO GOODWILL}

Os adeptos da mensuração do ativo por seu valor econômico, ou seja, pelo valor do fluxo futuro de resultados, entendem que os ativos deveriam representar todo o potencial de geração de lucros.

Tal entendimento está calcado na mensuração dos ativos a valores de saida.

E. MARTINS, em 1972, já pontificava que "em um Ativo definido em termos econômicos não existe, portanto, lugar para o 'goodwill'. Em uma Contabilidade fundamentada dessa forma o 'goodwill' simplesmente não existe". ${ }^{18}$

A existência de goodwill, independente de ativos serem avaliados pelos seus valores econômicos, denotaria, simplesmente, os limites e as dificuldades de identificaçāo de determinados potenciais dos ativos de difícil agregaçāo aos mesmos. Seria uma dificuldade de natureza prática, não teórica.

A questāo está na avaliação individual dos ativos e de toda a sociedade, o que vale dizer que a soma das partes não é igual ao todo, ao empreendimento.

A combinação de determinado conjunto de ativos, em uma atividade produtiva, gera uma dinâmica de resultados econômicos diferente daquela existente em cada um dos ativos considerados de per si.

Esse entendimento levou MONOBE, em 1986, a considerar a existência do que denominou goodwill sinergístico, concluindo que

18 Eliseu MARTINS, op. cit., p. 82. 
"ocorrendo sinergia positiva, o valor da empresa seria sempre maior que a soma dos valores econômicos de todos os ativos utilizados, sem exceção. Assim, se o contador fosse omnisciente, o goodwill seria atribuivel à sinergia da organização, um conceito muito mais útil para avaliação do comportamento da empresa e suas potencialidades". ${ }^{19}$

A literatura estrangeira sobre o tema goodwill vem de longa data.

BESTA (Apud HERMANN JR.) era de entendimento de que o goodwin ou aviamento poderia ser mensurado assim:

"O valor do aviamento de um negócio singular ou de uma empresa no seu conjunto é essencialmente igual ao valor atual do excesso dos lucros que, na hipótese de uma administração normal, dirigida por energias físicas, de vontade e inteligência normais, comuns, possam ser esperados ou presumidos de capitais investidos efetivamente no negócio ou empresa, sobre os lucros médios que costumam produzir capitais empregados com igual segurança em outros negócios ou empresas similares ou análogos, mas em condições comuns, não privilegiadas." ${ }^{20}$

Exemplos de contribuições significativas mais recentes podem ser encontrados em HENDRIKSEN e MOST.

HENDRIKSEN, considerando a complexidade de se mensurar o goodwill, à medida que falta-lhe, pelo menos, duas carateristicas, identificabilidade e separabilidade, entende ser possivel enfocar referido ativo sob três dimensōes:

1. avaliação de atitudes favoráveis em relação à sociedade;

2. valor presente descontado dos lucros futuros esperados acima do que pode ser considerado como retorno normal, exceto o goodwill; e,

3. conta mestra de avaliação - a diferença entre o valor de todo o negócio e - valor das avaliaçōes específicas dos seus ativos tangiveis e intangiveis. ${ }^{21}$

19 Massanori MONOBE, Contribuição à mensuraçđo e contabilizaçāo do goodivill não adquirido, p. 61.

20 Frederico HERMANN JR, Contabilidade superior: teoria económica da contabilidade, p. 179.

21 Eldon S. HENDRIKSEN, Michael F. VAN BREDA, Accounting theory, p. 640. 
Relações comerciais vantajosas, boas relaçōes com empregados e fornecedores são fatores de valorização do negócio:

"Essas atitudes favoráveis podem dever-se a uma situação vantajosa, a uma reputação e nome excelentes, a privilégios de monopólio, à boa administração do negócio e outros fatores. Quando o preço de compra de um negócio em marcha excede o total da avaliação de todos os seus ativos individuais, exceto o goodwill, pode-se assumir que este excedente representa o pagamento destes atributos intangiveis especificos." ${ }^{22}$

Portanto, tais elementos intangiveis, podem, em tese, ser objeto de mensuração.

O enfoque mais comum no que se refere à natureza do goodwill é que "ele representa o valor atual descontado dos ganhos futuros esperados lou fluxos de caixa para os acionistas) que superem o que se poderia considerar como um retorno normal." 23

\section{Prossegue questionando que:}

"a suposição de que os ativos tangiveis somente podem oferecer uma taxa de retorno normal enquanto que outros fatores são responsáveis pelo excedente é pura ficção. Os ativos tangiveis podem ter valor em seus usos especificos por causa da competição imperfeita e mudanças da demanda dos produtos, bem como pela sua eficiente utilização. Todos os fatores interagem na produção dos produtos ou serviços finais e na obtenção de lucros para os acionistas. Qualquer tentativa de alocar uma porção do valor total da empresa na base da capitalização de ganhos superiores, é, assim, artificial." $^{24}$

0 terceiro enfoque foi tratado, pioneiramente, por CANNING, ${ }^{25}$ que recomenda que o goodwill deveria ser registrado numa conta mestra de avaliação

\footnotetext{
Ibidem, p. 640.

Ibidem, p. 640-6+1.

Ibidem, p. $6 \$ 1$.

Ibidem, p. 641 .
} 
(master valuation account), na medida em que não é possivel ratear o valor total da sociedade entre seus ativos específicos.

MOST apresenta três significados distintos para a palavra goodwill no universo contábil

"(1) uma construção teórica: o valor presente dos resultados futuros ou a renda líquida que exceder ao retorno normal sobre o investimento;

(2) uma observação empírica: o excesso do preço pago por um negócio sobre o justo valor de mercado dos ativos que o compõem excluido o goodwill; e

(3) uma assertiva da técnica contábil: na consolidação das contas de um grupo, a parte do montante pago pela controladora para obter o controle que exceder a sua parcela dos ativos liquidos das subsidiárias". ${ }^{26}$

BEDFORD e BURTON (Apud MONOBE) acrescentam um quarto grupo como sendo aquele que:

"acredita ser o goodwill uma resultante do fenômeno da sinergia. Portanto, o goodwill não é um ativo independente como um ativo tangivel qualquer, que pode ser vendido ou trocado. Ao contrário, trata-se de um valor ligado a continuidade da empresa, representando o excesso do valor dos ativos combinados da mesma sobre a soma dos seus valores individuais". ${ }^{27}$

IUDÍCIBUS realça as dificuldades de se definir goodwill, assumindo que a menos pior foi aquela de KOHLER que definiu intangiveis assim: "um ativo de capital que não tem existência física, cujo valor é limitado pelos direitos e benefícios que antecipadamente sua posse confere ao proprietário". ${ }^{28}$

Aponta as posições discordantes de HENDRIKSEN e MOST sobre goodwill. Indica cinco características aceitas por HENDRIKSEN (indicando dentro do parênteses a posição de MOST), a saber:

"Vejamos as características:

\footnotetext{
6 Kenneth S. MOST, Accounting theory, p. 241.

Massanori MONOBE, op. cit., p. 57.

28 Sèrgio IUDICIBUS, Teoria da contabilidade, p. 176.
} 
1. Não são separáveis do valor da empresa como um todo (mas isto se aplica claramente apenas em alguns casos; o portador de contratos de alto valor e de direitos autorais teria pouca dificuldade para distingui-los do intangivel do negócio).

2. Há um alto grau de incerteza relativo ao valor dos benefícios futuros a serem recebidos (isto se aplicaria também a muitos itens do imobilizado tangivel e mesmo para algumas propriedades imobiliárias e para grande parte dos inventários).

3. Não se pode determinar o valor do ativo pela verificação da condição física, do custo de reposição ou de um valor corrente de mercado (ao comparar com ativos imobilizados tangiveis, a afirmativa é um truismo; entretanto, alguns ativos fixos perdem valor independentemente de sua condição física. Se o goodwill ou um produto patenteável têm um custo de reposição ou valor de mercado, é uma questão de fato em cada caso.)

4. Quanto ao valor a ser derivado dos benefícios futuros esperados, é impossivel determinar qual parte da receita deriva de um intangivel, especificadamente. (É o mesmo critério criticado em 1; além disso, a inabilidade em atribuir receitas a ativos específicos aplica-se igualmente à maioria dos ativos tangiveis.)

5. Surgem de condições de concorrência imperfeita. (Desde que a concorrência imperfeita é a norma e não a exceção em uma economia moderna, não tem sentido a afirmação.)" ${ }^{29}$

Como podemos observar, a conceituação clara do goodwill é tarefa ainda incompleta.

Vejam-se, por exemplo, BESSIERE e COISPEAU que o definem assim:

"o goodwill é concebido como um superlucro que é conveniente capitalizar num certo periodo. Esse superlucro traduz a noção de 'renda econômica' de que a empresa dispõe devido à qualidade de seus produtos, de sua

29 Sérgio IUDiCLBUS, op. cit., p. 181. 
administração, de sua rede de distribuição, de sua posição num mercado, de sua superioridade tecnológica, de sua notoriedade etc." ${ }^{30}$

Ou, ainda, PĖNE: "o goodwill ou sobrevalor corresponde pois ao excedente do rendimento econômico previsivel sobre a rentabilidade exigida dos capitais investidos". ${ }^{31}$

E. MARTINS coloca claramente as dificuldades da Contabilidade em mensurar o goodwill, assim:

\begin{abstract}
"know-how', propaganda eficiente, localização geográfica estratégica, habilidade administrativa fora dos padrões comuns, treinamento eficiente dos empregados, relações públicas favoráveis, legislação pública também favorável, condições monopolísticas etc. representam todos eles elementos que têm valor econômico. Estão dirigindo à entidade que os possui Resultados Econômicos que de outra forma não existiriam. Mas a Contabilidade, seguindo seus Princípios de Custo, Objetividade e Conservadorismo, tem preferido o seu não-reconhecimento." ${ }^{32}$
\end{abstract}

Buscando uma sintese do pensamento de MARTINS por meio das características fundamentais do goodwill (agente de reconhecido valor econômico; falta de tangibilidade; ausência ou dificuldade de mensuraçāo de custo; e inexistência de identificação individual), FERNANDES diz:

"Combinando tais elementos poder-se-ia formular a seguinte definição: goodwill é um ativo intangivel que se forma naturalmente pela combinação dos ativos na atuação da empresa. Com esta definição haveria condições de se reconhecer a relação entre o goodwill e a operação da empresa e se estaria recusando sua definição como 'fruto da subavaliação de ativos'(master valuation account) e também a visão de goodwill como superlucros". ${ }^{33}$

\footnotetext{
30 Véronique BESSIERE, Olivier COISPEAU, L'évaluation des entreprises, p. 120.

Didier PÉNE. Évaluation et prise de contröle de l'entreprise, v.2, p. 113.

Eliseu MARTINS, op. cit., p. 59.

33 Francisco Carlos FERNANDES, Goodwill, p. 8.
} 
EDWARDS e BELL, ${ }^{34}$ considerando a problemática avaliatória do goodwill, entendem que podemos considerar duas abordagens: goodwill objetivo e goodwill subjetivo, em função de quem o convalida.

Entendem que goodwill objetivo pode ser considerado como a diferença entre o valor de mercado da sociedade e o valor de mercado de seus ativos específicos. Portanto, é o próprio mercado que reconhece esse plus.

Já o goodwill subjetivo surge da diferença entre o valor da sociedade a ela atribuido por seus administradores ou proprietários e o valor de mercado de seus ativos específicos. Surge, portanto, de uma avaliação individual, subjetiva, permeada das preferências e avaliaçāo de risco personalizadas.

\subsection{GOODWILL ADQUIRIDO E NÃO ADQUIRIDO}

Apesar das controvérsias, há um aspecto em que encontramos consenso na maioria dos autores. Trata-se do goodwill adquirido e não adquirido, também denominado de goodwill formado internamente.

O goodwill adquirido, como a própria terminologia já indica, corresponde à parte do preço da alienação de determinado negócio, não identificada com os próprios ativos adquiridos, normalmente, materializado sob a figura de um ágio pago e registrado nos livros da sociedade adquirente.

O registro contábil do goodwill adquirido gera, por seu lado, toda a polêmica quanto ao não registro do goodwill formado internamente.

O goodwill formado internamente vai concretizando-se ao longo do tempo, por meio de diversas açōes, cujos gastos, quando os há, sāo geralmente considerados como despesas do período, além do que os registros contábeis tradicionais obedecem ao "Princípio do custo como base de valor", olvidando o valor econômico dos ativos.

34 Edgard O. EDWARDS, Plilip W. BELL. The theory and measurement of business income. cap. 2. 
A critica contundente que se faz ao reconhecimento do goodwill adquirido e não do outro (formado internamente) è a que se refere às distorções quanto à comparação entre sociedades semelhantes, pois aquela que tem goodwill formado internamente estaria prejudicada em sua análise.

\subsection{GOODWILL NEGATIVO OU BADWILL}

Em momentos anteriores admitimos que o goodwill surge em funçāo de que o valor da sociedade pode ser diferente da somatória dos valores econômicos de seus ativos individuais. Nesse diapasão, é plenamente justificável pensar na hipótese inversa, ou seja, a somatória dos valores dos ativos pode ser inferior ao valor de toda a sociedade.

Pode ser que determinadas linhas de produçāo ou segmentos operacionais, em termos econômicos, estejam contaminando o valor global, negativamente.

Assim, é importante identificar as razōes objetivas dessa distorção, saneando ou encerrando a parte operacional causadora desses efeitos negativos no valor global do empreendimento. Pode ser mais vantajoso para os proprietários vender o empreendimento por partes.

Do ponto de vista contábil, estamos diante do surgimento de um deságio.

Em processos judiciais que envolvem apuração de haveres, goodwill negativo apurado em sociedade em marcha significa a inexistência de goodwill, mormente em sociedades deficitárias; tem como conseqüência o abandono do referido valor negativo, considerando o perito, no balanço de determinação, apenas os valores dos elementos patrimoniais a preços de mercado. Isto quer dizer que seria economicamente mais vantajoso liquidar a sociedade do que mantê-la em funcionamento. 


\subsection{FÓRMULAS DE CÁLCULO DO GOODWILL}

Várias são as fórmulas de cálculo do goodwill que se utilizam dos lucros para o respectivo cálculo.

MONOBE ${ }^{35}$ sintetizou-as da forma como passamos a reproduzir:

A primeira considera o lucro liquido e determinado fator multiplicativo para obtenção do goodwill:

$$
G=(L L-R A-i \cdot A T) . F,
$$

onde:

$G=$ valor do goodwill

$\mathrm{LL}=$ lucro líquido

$\mathrm{RA}=$ remuneração da administração

i = taxa de juros aplicável ao capital imobilizado em ativos tangiveis

$A T=$ ativos tangiveis

F = fator multiplicativo para obtençāo do goodwill

Como variante da anterior, temos a que leva em consideração os lucros líquidos médios dos últimos cinco anos, denominada Método de Nova lorque:

$G=(L L M-R A-i \cdot A T) . F$,

onde:

G = valor do goodwill

LLM = lucro liquido médio dos últimos cinco anos

$\mathrm{RA}=$ remuneração da administração

i = taxa de juros aplicável ao capital imobilizado em ativos tangiveis

AT $=$ ativos tangiveis

F = fator multiplicativo para obtenção do goodwill

${ }^{35}$ Massanori MONOBE, op. cit., p. 66-69. 
A terceira fórmula, conhecida como de HATFIELD, introduz a visão do goodwill como resíduo em relação aos outros ativos:

$$
\begin{aligned}
& \mathbf{G}=[(L L-R A) / j]-A T, \\
& \text { onde: } \\
& G=\text { valor do goodwill } \\
& L L=\text { lucro líquido médio dos últimos cinco anos } \\
& \text { RA = remuneração da administração } \\
& j \quad=\text { taxa de capitalização dos lucros } \\
& \text { AT = ativos tangiveis }
\end{aligned}
$$

A quarta e última fórmula apura o valor atual dos superlucros, não incluindo quaisquer ativos intangíveis no cálculo, assim:

$$
G=\sum_{t=1}^{k} \frac{(L L t-R A-i . A T)}{(1+r)^{t}}
$$

onde:

$$
\begin{aligned}
G \quad= & \text { valor do goodwill } \\
L L t= & \text { lucro liquido no momento } t \text {, que seria decrescente, } \\
& \text { acarretando superlucros decrescentes } \\
R A= & \text { remuneração da administração } \\
i \quad= & \text { taxa de juros aplicável ao capital imobilizado em ativos tangiveis } \\
\text { AT }= & \text { ativos tangíveis } \\
r \quad= & \text { taxa de desconto atribuida aos superlucros } \\
k \quad= & \text { limite de duração dos superlucros }
\end{aligned}
$$

A avaliação do acervo patrimonial pelo valor econômico individual de cada um de seus componentes não faz desaparecer o denominado goodwill tradicional, 
pelo contrário, nas palavras de $\mathrm{MONOBE}^{36}$ faz aflorar seu conteúdo mais expressivo, o goodwill sinergistico da sociedade.

Considerando que o valor mais próximo do valor econômico do ativo advém da aplicação de um método misto, utilizando-se de avaliaçōes de ativos a valores de saida e custos de reposição, já que a sociedade atua tanto como compradora quanto como vendedora, MONOBE propōe a apuração do goodwill global, como a

"diferença entre os lucros líquidos projetados - um horizonte temporal de projeção muito utilizado é o de cinco anos - descontados pela taxa de remuneração de empreendimento de igual risco, que corresponderia ao custo de oportunidade do investimento". ${ }^{37}$

O goodwill global, em termos algébricos é representado pelo proponente, assim:

$G=\sum_{t=1}^{n} \frac{L L P_{t}}{(1+j)^{t}}-P L_{v c}$,

onde:

$L L P_{t}=$ lucro liquido projetado para o periodo $t$ futuro

j = taxa de desconto (custo de oportunidade) correspondente à remuneraçāo de empreendimento de igual risco

$\mathrm{PL}_{\mathrm{vc}}=$ patrimônio líquido em valores correntes (excluido o goodwill)

Como vimos anteriormente, EDWARDS e BELL propõem o que denominaram de goodwill objetivo e subjetivo; no primeiro, consideram em seu cálculo o valor de mercado da sociedade e a avaliação individual dos ativos e, no segundo, consideram os ganhos futuros esperados, conforme a expectativa de seus administradores ou proprietários e o valor de mercado de cada um de seus ativos.

Assim, teriamos dois montantes prováveis para o mesmo goodwill, a saber:

GO $=$ VME $-\Sigma$ VMAi,

onde: 
$\mathrm{GO}=$ goodwill objetivo

$\mathrm{VME}=$ valor de mercado de toda a empresa

$\mathrm{VMAi}=$ valor de mercado do ativo $\mathrm{Ai}$

E, para o goodwill subjetivo:

GS = VSE $-\Sigma$ VMAi,

onde:

GS = goodwill subjetivo

VSE = valor subjetivo de toda a empresa (o valor estimado dos benefícios futuros de todos os ativos)

$\mathrm{VMAi}=$ valor de mercado do ativo $\mathrm{Ai}$

FERNANDES, comentando o que propuseram EDWARDS e BELL, diz:

"O valor da empresa e o valor de seus ativos individualmente ganha relevância total, e os resultados (lucros) futuros esperados são vistos como atributos dos ativos. $A$ avaliação proposta por eles se aproxima muito mais do conceito de ativo para a Contabilidade e desvincula o goodwill dos lucros gerados no passado e do que seria uma taxa de lucratividade normal, muito embora, ao final das contas, exista uma grande relação entre o conceito econômico de ativo e a sua realização como resultado de um período". ${ }^{38}$

PaIa BESSIERE e COISPEAU,

"o fundamento de todos os métodos de avaliação do goodwill é a noção de rentabilidade dos ativos investidos na empresa. O superlucro, que será capitalizado em seguida, é calculado pela diferença entre a rentabilidade efetivamente obtida pela empresa e a rentabilidade 'normal' dos ativos". ${ }^{39}$ Com base nessa afirmação, propõem:

$S P=B-r A$,

onde:

39 Véronique BESSIERE, Olivier COISPEAU, op. cit., p. 120 
$\mathrm{SP}=$ superlucros

$B$ = lucros efetivamente obtidos pela empresa

$A=$ ativos envolvidos nas operações

$r$ = taxa de remuneração normal dos ativos

E. MARTINS preconiza, diante das dificuldades de mensuração do valor econômico dos ativos (o valor presente dos fluxos de benefícios futuros desses ativos) e em face da subjetividade inerente, uma possibilidade intermediária de se utilizar na avaliação dos ativos, um procedimento misto, que consiste na mensuraçăo do ativo total por seu valor econômico e seus respectivos componentes pelo custo corrente, designando a diferença entre um e outro, como "excesso sobre o valor corrente", ${ }^{40}$ adotando a seguinte fórmula, como consta em Monobe: ${ }^{41}$

$$
G=\sum_{t=1}^{n} \frac{L L t}{(1+j)^{t}}-P L_{c c},
$$

onde:

$\mathrm{G} \quad=$ valor do goodwill

LLt = lucro líquido do periodo $t$

j = taxa de desconto (custo de oportunidade) correspondente

à remuneraçāo do empreendimento de igual risco

$P L_{c c}=$ patrimônio líquido a custos correntes

$\mathrm{n} \quad=$ número de periodos utilizado para apuração do goodwill

Trata-se, como se pode constatar nas formulaçōes, de cálculos com base nos lucros obtidos ou esperados.

Como se observou, ao longo desta seção, o consenso é ainda uma quimera. Muitas sāo as opiniōes e, conseqüentemente, as fórmulas de mensuração. Embora, ao leitor possa parecer negativo, essa profusāo de fórmulas e de entendimentos, demonstra, ao contrário, a riqueza técnica e científica do assunto.

${ }^{40}$ Eliseu MARTINS, op. cit., p. 88.

41 Massanori MONOBE, op. cit., p. 74. 


\subsection{PROPOSIÇÃO}

Como já se disse alhures, o perito em contabilidade dificilmente tem acesso aos orçamentos ou projeçōes futuras.

Quando da época de realização do trabalho pericial de apuração de haveres, o futuro já será passado.

Os sucessos ou fracassos futuros, como já dito em momento anterior, não alcançam as quotas a serem reembolsadas. Portanto, só resta ao expert socorrer-se dos resultados econômicos históricos anteriores à data do evento, se a sociedade possuir escrituração mercantil devidamente formalizada.

A taxa de desconto ou custo de oportunidade semelhante à rentabilidade de empreendimento de igual risco é informação, na maioria dos casos, indisponivel.

Todas as fórmulas de mensuração do goodwill têm seus méritos, mas, como os usuários dos laudos periciais contábeis de apuração de haveres são pessoas não afeitas a seus significados, temos de descodificá-las, a fim de que tornem inteligiveis e compativeis com o conceito de sobrevalor preconizado pelos comercialistas.

Considerando que o patrimônio líquido consignado no balanço de determinação, antes da apuraçāo do goodwill, já reflete o valor econômico de cada um dos elementos patrimoniais da sociedade avalianda na data base do evento, sancionado pelo mercado, para finalizar o processo avaliatório é necessário mensurar se o todo patrimonial é superior à somatória dos valores individuais daqueles elementos; em outras palavras, resta constatar a existência ou nảo do chamado efeito sinérgico, originário da combinação dos elementos patrimoniais entre si.

É o que propomos a seguir. 


\subsubsection{Premissas}

$\mathrm{Na}$ construção do modelo proposto de mensuraçăo do efeito sinérgico, é necessário assumir determinadas premissas e o fazemos mediante a formulação de perguntas.

Se o goodwill sinergístico è a capacidade que determinada sociedade possui de gerar lucros acima do normal, o que pode ser entendido por lucro normal?

Para nós, o Lucro Normal ( $L M$ ) da sociedade avalianda corresponde ao rendimento (lucro) que o ativo operacional líquido a valores de mercado, não incluido o goodwill, pode gerar se aplicado a uma taxa de juros correspondente ao custo do capital próprio.

Assumimos, também, que o custo do capital próprio corresponde à taxa máxima de juros permitida por lei que os particulares podem ajustar em seus negócios; isso equivale a $12 \%$ (doze por cento) ao ano, conforme disposto no art. $1^{\circ}$, Decreto $n^{\circ} 22.626$, de 7 de abril de $1933 .^{42}$

Mais duas razões dão guarida à utilização da taxa de $12 \%$. A primeira advém do próprio contrato social no qual os contratantes (sócios) ao disporem sobre a forma de apuração e pagamento dos haveres ajustam, normalmente, essa taxa aplicada sobre o valor do reembolso das quotas. A segunda decorre da própria sentença judicial que determina o pagamento dos haveres acrescidos dos juros contratuais ou dos legais. É, portanto, necessário excluir do cálculo do goodwill a remuneração do capital (haveres) garantida pelo contrato social e na sentença, evitando-se assim o denominado bis in idem que não encontra guarida no ordenamento jurídico pátrio.

12 Lei da Usura: "Art. $I^{\circ} \dot{E}$ vedado e será punido nos termos desta lei estipular, em quaisquer contratos, taxas de juros superiores ao dobro da taxa legal (Código Civil, art. 1.062)."

Código Civil: "Art. 1.062. A taxa dos juros moratorios, quando não convencionada (art. 1.962), será de seis por cento ao ano." 
Para aquilatarmos se a sociedade avalianda gera lucro operacional acima do normal, é necessário indagar o que pode ser entendido por lucro gerado pelas operaçōes.

Assumimos que o lucro gerado pelas operações (lucro operacional líquido) corresponde ao lucro liquido do exercicio, excluídas as receitas e despesas financeiras, deduzido das provisões tributárias incidentes sobre referido lucro.

O lucro gerado pelos ativos não operacionais e os resultados de transações eventuais, ou comumente denominadas de não operacionais, exceto o saldo de correção monetária que por sua própria natureza tem caráter nitidamente operacional, são também excluidos do lucro operacional líquido.

O que pode ser entendido por lucro operacional líquido: são os lucros operacionais liquidos históricos ajustados, ou os lucros operacionais liquidos futuros?

Considerando que os insucessos ou sucessos da sociedade avalianda após a data do evento não alcançam as quotas do sócio retirante ou pré-morto, só resta considerar os lucros operacionais líquidos históricos ajustados do período imediatamente anterior ao evento; portanto, descartada a alternativa de lucros futuros projetados. Não se trata de mera compilação de dados históricos; há que equacioná-los mediante a utilizaçāo da técnica denominada "Correção Monetária Integral".

Os lucros operacionais líquidos históricos, ajustados como no item anterior são atualizados monetariamente para a época do evento; em seguida, apuramos o lucro médio do periodo escolhido, imediatamente anterior ao evento, especialmente se se tratar de sociedade com comportamento cíclico em termos de resultados econômicos.

Recomendamos, por outro lado, que a atualização monetária seja realizada mediante a utilização de indexadores aceitos pelos Tribunais, o que evita 0 surgimento de polèmicas. 
Assim, assumimos que o lucro operacional líquido médio histórico ajustado (LOLmha), em moeda constante, é o lucro gerado pelas operações da sociedade. Assumimos também o lucro operacional líquido médio histórico ajustado afim de minimizar eventuais sazonalidades operacionais ou processos de crescimento acentuado que não se repetirāo no futuro.

Conhecidos o lucro gerado pelas operações e o lucro normal, como surge o lucro acima do normal?

O lucro acima do normal corresponde à diferença entre o lucro operacional líquido médio histórico ajustado, em moeda constante, e o lucro normal. A diferença assim apurada poderá resultar em três situaçōes distintas:

- Lucro normal superior ao lucro operacional líquido médio histórico ajustado

Essa situação evidencia a inexistência do efeito sinérgico; o ativo operacional liquido a valores de mercado aplicado à taxa correspondente ao custo do capital próprio gera lucro superior ao que advém das operaçōes, conseqüentemente inexiste goodwill. Essa é uma situação típica de badwill, ou seja, é mais vantajoso liquidar a sociedade do que mantê-la em operação.

- Lucro normal igual ao lucro operacional líquido médio histórico ajustado

Trata-se de situação rara, mas possivel; para efeito de mensuração do efeito sinérgico, deparamo-nos com uma situação neutra; não se configura a existência de goodwill, tampouco de badwill.

- Lucro normal inferior ao lucro operacional liquido médio histórico ajustado

Esta situação caracteriza a existência do efeito sinérgico, ou seja, a sociedade possui capacidade de gerar lucros acima do normal (LAN); portanto, possui goodwill.

A diferença positiva entre o lucro operacional líquido médio histórico ajustado e o lucro normal ( $L O L m h a-L N=L A N)$ é assumida como uma renda 
perpétua dividida pelo custo do capital próprio, obtendo-se assim a mensuração do goodwill.

Resta ainda abordar a questão das necessidades de caixa para futuros investimentos fixos e de capital de giro.

O modelo proposto releva essa questão nāo sem motivo. O goodwill considerado na avaliaçāo reflete apenas o efeito sinérgico originário da combinação dos ativos na data-base. $O$ ativo operacional líquido é tomado por seu valor de mercado; assim, é desnecessário qualquer ajuste sob o argumento de que o custo de reposição possa ser maior no futuro; valem o que o mercado sanciona na data do evento. O lucro operacional líquido adotado é o médio histórico que já embute a depreciação e amortizaçāo média do período anterior considerado.

Em face das determinações judiciais não há como considerar se a sociedade, após o evento, irá expandir-se ou regredir, ou seja, o futuro não pertence ao sócio retirante, tampouco aos herdeiros do sócio pré-morto.

Em decorrència de tudo quanto foi assumido, indagamos: qual é o valor da sociedade avalianda?

Considerando todas as premissas assumidas, delas resulta que o valor da sociedade corresponde ao património líquido a valores de mercado ( $P$ LVm), acrescido do eventual goodwill $(G)$ e este só existe quando o lucro considerado normal è inferior ao lucro operacional líquido médio.

Nas hipóteses em que o lucro normal é superior ou igual ao lucro operacional líquido médio histórico ajustado, o valor da sociedade corresponde, exclusivamente, ao patrimônio líquido a valores de mercado. Tal situação revela que a sociedade avalianda gera lucros e fluxos de caixa operacionais que não remuneram o capital próprio. 


\subsubsection{Fórmulas propostas}

As premissas assumidas podem ser operacionalizadas, adotando-se as fórmulas a seguir demonstradas:

- Cálculo do lucro normal

$$
L N=A O L v m \cdot i \text {, }
$$

onde:

$\mathrm{LN} \quad=$ lucro normal

AOLvm = ativo operacional líquido a valores de mercado

i = custo do capital próprio

- Cálculo do lucro operacional líquido médio histórico ajustado

$L O L=L L+(D F-R F-R A N O+/-R N O)-P T$

onde:

LOL = lucro operacional líquido

$\mathrm{LL} \quad=$ lucro líquido

DF $\quad=$ despesas financeiras

$\mathrm{RF} \quad=$ receitas financeiras

RANO = resultado ativos não operacionais

RNO = resultados năo operacionais

PT = provisões tributárias sobre o lucro operacional

Esse cálculo deve ser repetido para cada um dos exercícios anteriores ao evento, adotados pelo perito.

Finalizados referidos cálculos, os lucros líquidos históricos ajustados são trazidos para moeda da época do evento e, em seguida, apuramos a média simples, 
surgindo, então, o Lucro operacional líquido médio histórico ajustado (LOLmha), em moeda constante.

- Cálculo do lucro acima do normal

LAN $=$ LOLmha $-L N$.

onde:

LAN = lucro acima do normal

$L O L_{m h a}=$ lucro operacional líquido médio histórico ajustado

$\mathrm{LN} \quad=$ lucro normal

Apurada diferença positiva originária de o lucro operacional líquido médio histórico ajustado superior ao lucro normal, os cálculos prosseguem para o estágio subseqüente; essa diferença positiva evidencia a existência do efeito sinérgico.

Apurada diferença negativa ou nula, fica evidenciada a inexistência do efeito sinérgico, portanto, a sociedade avalianda não possui capacidade de gerar lucros acima do normal e, conseqüentemente, inexiste goodwill.

- Cálculo do goodwill

$\mathbf{G}=\mathrm{LAN} / \mathbf{i}$,

onde:

$\mathrm{G} \quad=$ goodwill

LAN = lucro acima do normal

$\mathrm{i} \quad=$ custo do capital próprio

O valor do goodwill é consignado no balanço de determinação, tanto no ativo quanto no patrimônio líquido. 
- Cálculo do valor da sociedade

$$
\text { VS }=P L v m+G
$$

onde:

VS = valor da sociedade

$\mathrm{PL}_{\mathrm{vm}}=$ patrimônio líquido a valores de mercado

$\mathrm{G} \quad=$ goodwill

O valor assim apurado corresponde ao patrimônio líquido consignado no balanço de determinação, que serve de base para a apuração dos haveres do sócio retirante ou pré-morto.

\subsubsection{Alguns comentários sobre a proposição}

A proposição leva em conta que é necessário transmitir a seus usuários a visão de que o goodwill ou aviamento corresponde ao efeito sinérgico, ou seja, a avaliação do todo patrimonial pode ser superior à avaliação individual de cada um de seus componentes; corresponde esse efeito à capacidade que a sociedade possui de gerar lucros acima daquele considerado normal; tem, portanto, caráter do algo mais, do plus, do sobrevalor.

Introduz os usuários dos laudos periciais contábeis de apuração de haveres e os profissionais da perícia contábil na noção de que o Patrimônio Líquido pode ser entendido como se aplicação financeira fosse, à medida que propōe que o lucro normal resulta da aplicação de uma taxa de juros correspondente ao custo do capital próprio.

Leva em consideração fórmulas de fácil assimilação, sem descuidar do rigor técnico.

O modelo proposto alcança uma gama significativa de sociedades dissolvidas parcialmente por decisão judicial: aquelas com passivos financeiros 
normais. A constatação da existência de passivo financeiro extremamente oneroso ou subsidiado coloca a necessidade de considerar tal fato na mensuração do goodwill, ajustando o lucro operacional líquido aos efeitos das despesas financeiras onerosas ou subsidiadas.

Outra limitaçāo que merece ser lembrada é a relativa ao componente pessoal. Pode ser que o sócio retirante ou pré-morto era a pessoa-chave do negócio; entretanto, cabe observar que tal aspecto năo faz parte do foco deste trabalho.

Por derradeiro, o modelo proposto não leva em consideração o efeito da falta de liquidez sobre o valor da sociedade mesmo porque, juridicamente, a dissolução societária parcial não pode ser entendida como uma transação de compra e venda; assim, o perito judicial contábil mensura o valor da sociedade nāo seu preço.

\subsubsection{Testando o modelo}

Alguns ensaios sāo a seguir oferecidos.

Como primeiro ensaio apresentamos o valor da sociedade sem qualquer ajuste avaliatório, a fim de servir como referência aos ensaios subseqüentes, como evidenciado na Figura 4.

O segundo ensaio considera dois ajustes avaliatórios; o ativo permanente operacional contábil sofre ajuste para refletir o valor de mercado apurado no laudo de engenharia; sāo apuradas e consideradas contingências; considera os efeitos tributários originários dos ganhos de capital liquidos, como ilustrado na Figura 5. Observamos que o valor total da sociedade aumenta; todavia, o valor do goodwill é reduzido

O terceiro considera todos os ajustes anteriores acrescidos de ajuste avaliatório no ativo circulante operacional, originário, por exemplo, de ganhos de 
estocagem, como ilustrado na Figura 6 , observando o mesmo efeito relatado no ensaio anterior.

O quarto ensaio mantém todos os ajustes anteriormente relatados, agora acrescentados daquele realizado no ativo não operacional que, por exemplo, pode referir-se à reavaliação de terreno para futuras instalaçōes reportada no laudo de engenharia, como observamos na Figura 7. Notemos que essa alternativa não afeta o valor do goodwill; entretanto, aumenta o valor total da sociedade, por conta da reavaliação do ativo não operacional.

O quinto ensaio combina todos os efeitos anteriores, adicionando ajustes no passivo operacional (por exemplo: dividas com fornecedores não registradas, assumindo-se que a contrapartida seja estoques, os quais foram considerados no inventário) e no passivo financeiro (por exemplo: variação cambial não registrada), como vemos na Figura 8 . A combinação desses dois ajustes provoca um acréscimo no valor total da sociedade decorrente do aumento do valor do goodwill em valor superior ao aumento das obrigações.

Como podemos notar em todos os ensaios apresentados, foram mantidos fixos os valores contábeis e variados os valores de mercado em função das várias ocorrências relatadas.

A fim de evidenciar uma situação operacional diferente, no sexto ensaio modificamos os dados contábeis com o objetivo de demonstrar os efeitos numa situação de ativo operacional líquido negativo, mantendo o mesmo lucro operacional líquido, como disponivel na Figura 9. Constatamos que a sociedade possui goodwill, à medida que financia sua atividade operacional com capital de terceiros, sem custo financeiro explícito. Reflete, por sua vez, uma situação operacional de giro rápido de seus estoques financiados por seus fornecedores. 


\begin{tabular}{|l|}
\hline Itens \\
Patrimoniais \\
\hline Ativo circulante operacional \\
Ativo permanente operacional \\
(=) Ativo operacional total \\
(-) Passivo operacional \\
(=) Ativo operacional líquido - AOL \\
Disponibilidades \\
Ativo não operacional \\
(-) Passivo financeiro \\
(-) Contingências \\
(=) Ativo não operacional líquido \\
(-) IR ganhos de capital (40\%) \\
Patrimônio líquido - VS \\
Patrimônio liquido contábil \\
Ganhos de capital líquido \\
Goodwill
\end{tabular}

\begin{tabular}{|r|}
\hline Valor \\
Contábil \\
\hline 10.000 \\
7.000 \\
17.000 \\
-8.000 \\
9.000 \\
\\
5.496 \\
5.000 \\
-6.000 \\
0 \\
4.496 \\
0 \\
13.496 \\
13.496 \\
0 \\
0 \\
\hline
\end{tabular}

\begin{tabular}{|r|}
\hline Valor \\
Mercado \\
\hline 10.000 \\
7.000 \\
17.000 \\
-8.000 \\
9.000 \\
\\
5.496 \\
5.000 \\
-6.000 \\
0 \\
4.496 \\
0 \\
24.496 \\
13.496 \\
0 \\
11.000 \\
\hline
\end{tabular}

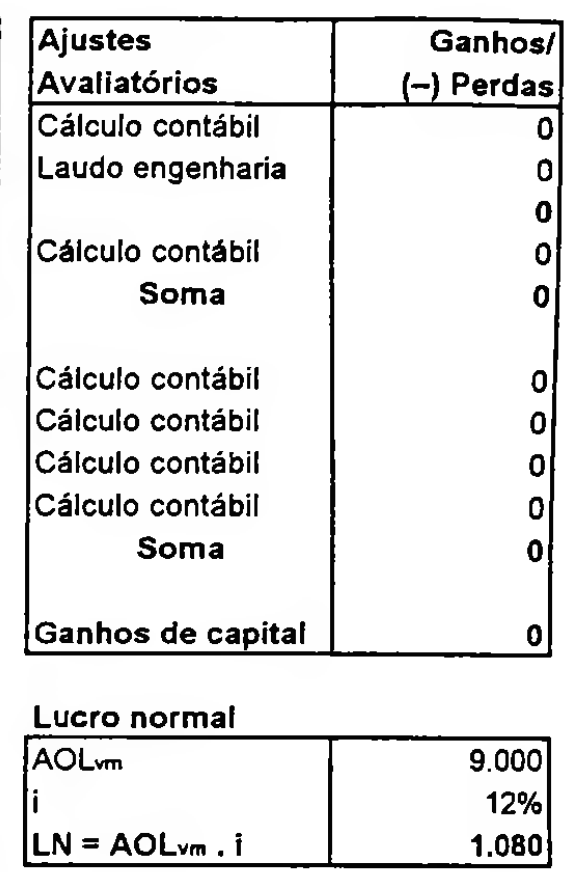

Lucro operacional

Receitas financeiras

Despesas financeiras

Resultado ativo não operacionais

Resultados nảo operacionais

Lucro antes IR

IR (40\%)
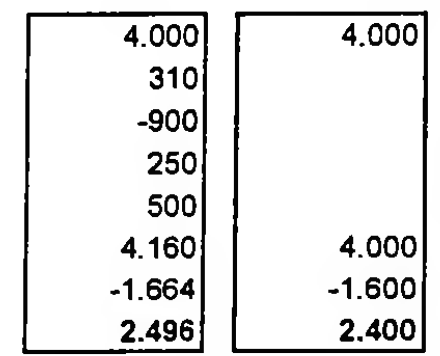

Goodwill

\begin{tabular}{|l|r|}
\hline LOL & 2.400 \\
LN & 1.080 \\
LAN = LOL - LN & 1.320 \\
$\mathrm{i}$ & $12,0 \%$ \\
G $=$ LAN $/ \mathrm{i}$ & 11.000 \\
\hline
\end{tabular}

\begin{tabular}{|l|r|}
\hline Valor da sociedade & Mercado \\
\hline Valor do ativo operacional liquido a 12\% & 20.000 \\
Ativo nảo operacional liquido & 4.496 \\
(-) IR ganhos de capital (40\%) & 0 \\
Goodwill & 0 \\
\hline Valor da sociedade & 24.496 \\
\hline Diferença avaliatória & \\
\hline
\end{tabular}

\begin{tabular}{|r|r|}
\hline Contábil & Individual \\
\hline 9.000 & 9.000 \\
4.496 & 4.496 \\
0 & 0 \\
0 & 11.000 \\
\hline 13.496 & 24.496 \\
\hline 11.000 & \\
\hline
\end{tabular}

\section{Demonstração da diferença avaliatória}

Ganhos de capital Ilquido

Goodwill

Figura 4 Valor da sociedade inclusive goodwill, sem ajustes avaliatórios 


\begin{tabular}{|l|}
\hline Itens \\
Patrimoniais \\
\hline Ativo circulante operacional \\
Ativo permanente operacional \\
(=) Ativo operacional total \\
$(-)$ Passivo operacional \\
(=) Ativo operacional liquido - AOL \\
Disponibilidades \\
Ativo não operacional \\
(-) Passivo financeiro \\
(-) Contingėncias \\
(=) Ativo não operacional liquido \\
(-) IR ganhos de capital (40\%) \\
Património líquido - VS \\
Património líquido contábil \\
Ganhos de capital líquido \\
Goodwill
\end{tabular}

\begin{tabular}{|r|}
\hline Valor \\
Contábil \\
\hline 10.000 \\
7.000 \\
17.000 \\
-8.000 \\
9.000 \\
\\
5.496 \\
5.000 \\
-6.000 \\
0 \\
4.496 \\
0 \\
13.496 \\
13.496 \\
0 \\
0 \\
\hline
\end{tabular}

\begin{tabular}{|r|}
\hline Valor \\
Mercado \\
\hline 10.000 \\
12.000 \\
22.000 \\
-8.000 \\
14.000 \\
\\
5.496 \\
5.000 \\
-6.000 \\
-1.000 \\
3.496 \\
-1.600 \\
\\
21.896 \\
13.496 \\
2.400 \\
6.000 \\
\hline
\end{tabular}

\begin{tabular}{|c|c|}
\hline $\begin{array}{l}\text { Ajustes } \\
\text { Avaliatórios }\end{array}$ & $\begin{array}{r}\text { Ganhos/ } \\
\text { (-) Perdas }\end{array}$ \\
\hline Cálculo contábil & 0 \\
\hline Laudo engenharia & 5.000 \\
\hline & 5.000 \\
\hline Cálculo contábil & 0 \\
\hline Soma & 5.000 \\
\hline Cálculo contábil & 0 \\
\hline Cálculo contábil & 0 \\
\hline Cálculo contábil & 0 \\
\hline Cálculo contábil & -1.000 \\
\hline Soma & -1.000 \\
\hline Ganhos de capital & 4.000 \\
\hline \multicolumn{2}{|l|}{ Lucro normal } \\
\hline AOLvm & 14.000 \\
\hline i & $12 \%$ \\
\hline$L N=A O L v m .1$ & 1.680 \\
\hline
\end{tabular}

Lucro operacional

Receitas financeiras

Despesas financeiras

Resultado ativo nāo operacionais

Resultados não operacionais

Lucro antes IR

IR (40\%)

Lucro líquido
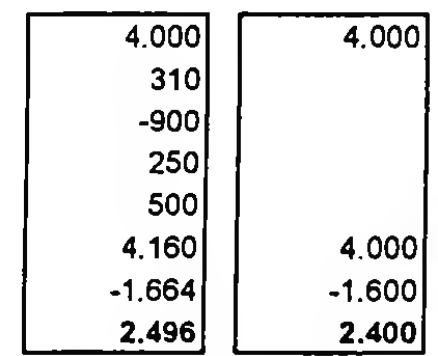

Goodwill
\begin{tabular}{|l|r|}
\hline LOL & 2.400 \\
LN & 1.680 \\
LAN = LOL - LN & 720 \\
i & $12,0 \%$ \\
G = LAN /i & 6.000 \\
\hline
\end{tabular}

\begin{tabular}{|l|r|}
\hline Valor da sociedade & Mercado \\
\hline Valor do ativo operacional liquido a 12\% & 20.000 \\
Ativo nảo operacional liquido & 3.496 \\
(-) IR ganhos de capital (40\%) & -1.600 \\
Goodwill & 0 \\
\hline Valor da sociedade & 21.896 \\
\hline Diferença avaliatória & \\
\hline
\end{tabular}

\begin{tabular}{|r|r|}
\hline Contábil & Individual \\
\hline 9.000 & 14.000 \\
4.496 & 3.496 \\
0 & -1.600 \\
0 & 6.000 \\
\hline 13.496 & 21.896 \\
\hline 8.400 & \\
\hline
\end{tabular}

\begin{tabular}{|l|r|}
\hline Demonstraçāo da diferença avaliatória & \\
\hline Ganhos de capital liquido & 2.400 \\
Goodwill & 6.000 \\
Diferença & 8.400 \\
\hline
\end{tabular}

Figura 5 Valor da sociedade inclusive goodwill, com ajustes avaliatónios no ativo permanente operacional $\theta$ contingèncias 


\begin{tabular}{|l|}
\hline Itens \\
Patrimoniais \\
\hline Ativo circulante operacional \\
Ativo permanente operacional \\
(=) Ativo operacional total \\
(-) Passivo operacional \\
(=) Ativo operacional liquido - AOL \\
Disponibilidades \\
Ativo não operacional \\
(-) Passivo financeiro \\
$(-)$ Contingèncias \\
(=) Ativo năo operacional líquido \\
(-) IR ganhos de capital (40\%) \\
Patrimònio líquido - VS \\
Patrimönio Ilquido contábil \\
Ganhos de capital liquido \\
Goodwill
\end{tabular}

\begin{tabular}{|r|}
\hline Valor \\
Contábil \\
\hline 10.000 \\
7.000 \\
17.000 \\
-8.000 \\
9.000 \\
\\
5.496 \\
5.000 \\
-6.000 \\
0 \\
4.496 \\
0 \\
13.496 \\
13.496 \\
0 \\
0 \\
\hline
\end{tabular}

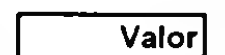

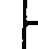
Mercado 11.000 12.000

23.000 $-8.000$ 15.000

5.496

5.000

$-6.000$

$-1.000$

3.496

$-2.000$

21.496

13.496

3.000

5.000

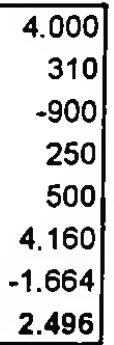

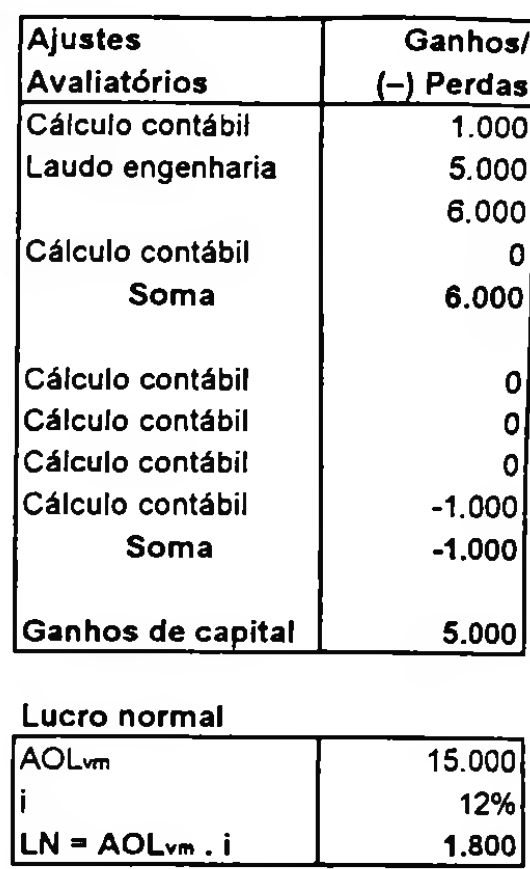

Goodwill

\begin{tabular}{|l|r|}
\hline LOL & 2.400 \\
LN & 1.800 \\
LAN = LOL - LN & 600 \\
$i$ & $12,0 \%$ \\
G = LAN / i & 5.000 \\
\hline
\end{tabular}

Lucro líquido

Lucro operacional

Receitas financeiras

Despesas financeiras

Resultado ativo não operacionais

Resultados não operacionais

Lucro antes IR

IR $(40 \%)$

\begin{tabular}{|l|r|}
\hline Valor da sociedade & Mercado \\
\hline Valor do ativo operacional liquido a 12\% & 20.000 \\
Ativo năo operacional liquido & 3.496 \\
(-) IR ganhos de capital (40\%) & -2.000 \\
Goodwill & 0 \\
\hline Valor da sociedade & 21.496 \\
\hline Diferença avaliatória & \\
\hline
\end{tabular}

\begin{tabular}{|r|r|}
\hline Contábil & Individual \\
\hline 9.000 & 15.000 \\
4.496 & 3.496 \\
0 & -2.000 \\
0 & 5.000 \\
\hline 13.496 & 21.496 \\
\hline 8.000 & \\
\hline
\end{tabular}

\begin{tabular}{|l|r|}
\hline Demonstraçảo da diferença avaliatória & \\
\hline Ganhos de capital liquido & 3.000 \\
Goodwill & 5.000 \\
Diferença & 8.000 \\
\hline
\end{tabular}

Figura 6 Valor da sociedade inclusive goodwill, com ajustes avaliatórios no ativo circulante e permanente operacional e contingências 


\begin{tabular}{|l|}
\hline Itens \\
Patrimoniais \\
\hline Ativo circulante operacional \\
Ativo permanente operacional \\
(=) Ativo operacional total \\
(-) Passivo operacional \\
(=) Ativo operacional líquido - AOL \\
Oisponibilidades \\
Ativo não operacional \\
(-) Passivo financeiro \\
(-) Contingèncias \\
(=) Ativo não operacional líquido \\
(-) IR ganhos capital (40\%) \\
Patrimônio líquido - VS \\
Património Ilquido contábil \\
Ganhos de capital líquido \\
Goodwill
\end{tabular}
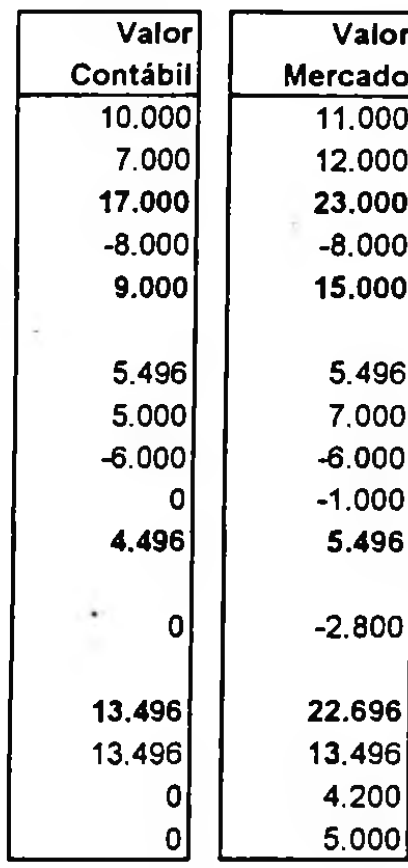

\begin{tabular}{|c|c|}
\hline $\begin{array}{l}\text { Ajustes } \\
\text { Avaliatórios }\end{array}$ & $\begin{array}{r}\text { Ganhos/ } \\
\text { (-) Perdas }\end{array}$ \\
\hline Cálculo contábil & 1.000 \\
\hline Laudo engenharia & 5.000 \\
\hline & 6.000 \\
\hline $\begin{array}{c}\text { Cálculo contábil } \\
\text { Soma }\end{array}$ & $\begin{array}{r}0 \\
6.000\end{array}$ \\
\hline Cálculo contábil & 0 \\
\hline Cálculo contábil & 2.000 \\
\hline Cálculo contábil & 0 \\
\hline Cálculo contábil & -1.000 \\
\hline Soma & 1.000 \\
\hline Ganhos de capital & 7.000 \\
\hline \multicolumn{2}{|l|}{ Lucro normal } \\
\hline AOLvm & 15.000 \\
\hline i & $12 \%$ \\
\hline$L N=A O L v m . i$ & 1.800 \\
\hline
\end{tabular}

Lucro operacional

Receitas financeiras

Despesas financeiras

Resultado ativo não operacionais

Resultados nåo operacionais

Lucro antes IR

IR (40\%)

Lucro liquido
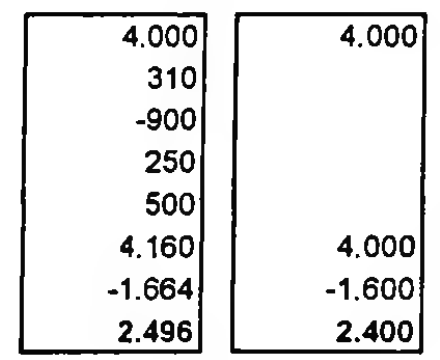

Goodwill
\begin{tabular}{|l|r|}
\hline LOL & 2.400 \\
LN & 1.800 \\
LAN = LOL - LN & 600 \\
\hline i & $12,0 \%$ \\
G = LAN /i & 5.000 \\
\hline
\end{tabular}

\begin{tabular}{|l|r|}
\hline Valor da sociedade & Mercado \\
\hline Valor do ativo operacional liquido a 12\% & 20.000 \\
Ativo nåo operacional liquido & 5.496 \\
(-) IR ganhos de capital (40\%) & -2.800 \\
Goodwill & 0 \\
\hline Valor da sociedade & 22.696 \\
\hline Diferença avaliatória & \\
\hline
\end{tabular}

\begin{tabular}{|r|r|}
\hline Contábil & Individual \\
\hline 9.000 & 15.000 \\
4.496 & 5.496 \\
0 & -2.800 \\
0 & 5.000 \\
\hline 13.496 & 22.696 \\
\hline 9.200 & \\
\hline
\end{tabular}

Demonstração da diferença avaliatória

Ganhos de capital llquido

Goodwill

4.200

Diferença

Figura 7 Valor da sociedade inclusive goodwill, com ajustes avaliatórios no ativo circulante $\theta$ permanente operacional, ativo nāo operacional e contingências 


\begin{tabular}{|l|}
\hline Itens \\
Patrimoniais \\
\hline Ativo circulante operacional \\
Ativo permanente operacional \\
(=) Ativo operacional total \\
(-) Passivo operacional \\
(=) Ativo operacional líquido - AOL \\
Disponibilidades \\
Ativo não operacional \\
(-) Passivo financeiro \\
(-) Contingẻncias \\
(=) Ativo não operacional líquido \\
(-) IR ganhos capital (40\%) \\
Património líquido - Vs \\
Património llquido contábil \\
Ganhos de capital líquido \\
Goodwill
\end{tabular}
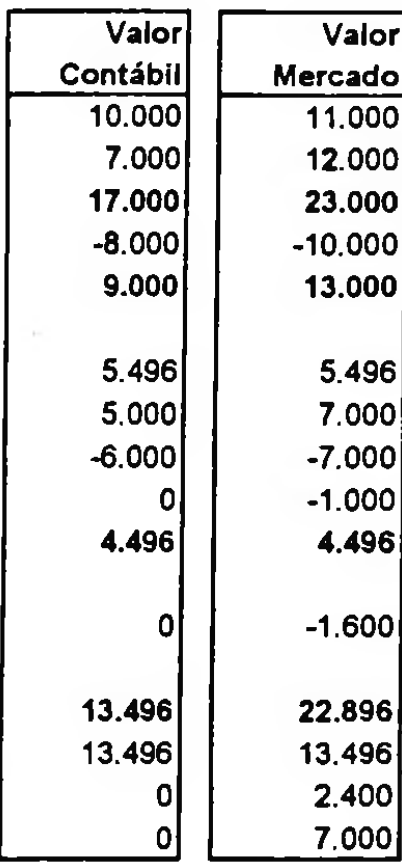

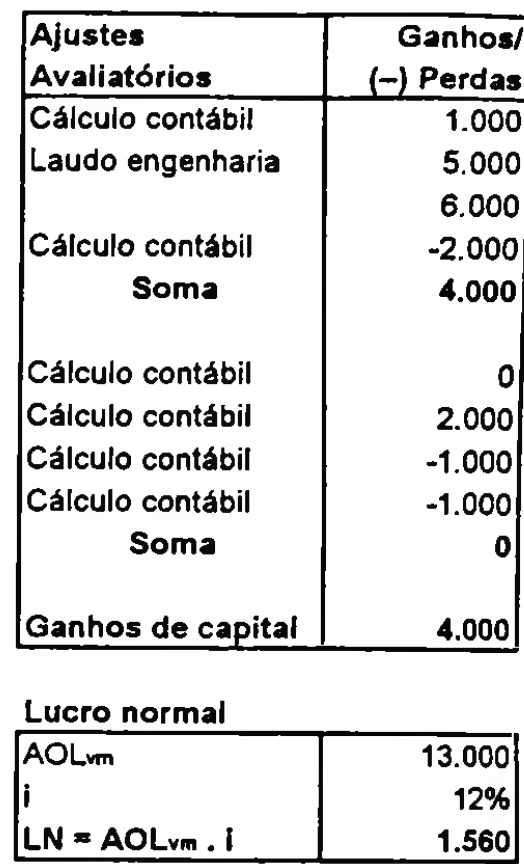

Lucro operacional

Receitas financeiras

Despesas financeiras

Resultado ativo nảo operacionais

Resultados nảo operacionais

Lucro antes IR

IR (40\%)

Lucro liquido

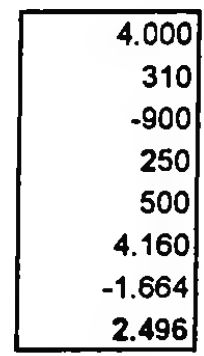

4.000

Goodwill

\begin{tabular}{|l|r|}
\hline LOL & 2.400 \\
LN & 1.560 \\
LAN = LOL - LN & 840 \\
$i$ & $12,0 \%$ \\
\hline G $=$ LAN / i & 7.000 \\
\hline
\end{tabular}

\begin{tabular}{|l|r|}
\hline Valor da sociedade & Mercado \\
\hline Valor do ativo operacional Ilquido a 12\% & 20.000 \\
Ativo nåo operacional llquido & 4.496 \\
(-) IR ganhos de capital (40\%) & -1.600 \\
Goodwill & 0 \\
\hline Valor da sociedade & 22.896 \\
\hline Diferença avaliatória & \\
\hline
\end{tabular}

\begin{tabular}{|r|r|}
\hline Contábil & Individual \\
\hline 9.000 & 13.000 \\
4.496 & 4.496 \\
0 & -1.600 \\
0 & 7.000 \\
\hline 13.496 & 22.896 \\
\hline 9.400 & \\
\hline
\end{tabular}

Demonstraçāo da diferença avaliatória

Ganhos de capital Ilquido

Goodwill

Diferença

Figura 8 Valor da sociedade inclusive goodwill, com ajustes avaliatónios no ativo circulante, permanente $\theta$ passivo operacional, ativo nåo operacional, passivo financeiro e contingéncias 


\begin{tabular}{|l|}
\hline Itens \\
Patrimoniais \\
\hline Ativo circulante operacional \\
Ativo permanente operacional \\
(=) Ativo operacional total \\
(-) Passivo operacional \\
(=) Ativo operacional líquido - AOL \\
Disponibilidades \\
Ativo não operacional \\
(-) Passivo financeiro \\
(-) Contingèncias \\
(=) Ativo não operacional líquido \\
(-) IR ganhos de capital (40\%) \\
Patrimônio líquido - VS \\
Património liquido contábil \\
Ganhos de capital llquido \\
Goodwill
\end{tabular}

\begin{tabular}{|r|}
\hline Valor \\
Contábil \\
\hline 5.000 \\
5.000 \\
10.000 \\
-13.000 \\
-3.000 \\
\\
5.496 \\
5.000 \\
-6.000 \\
0 \\
4.496 \\
0 \\
13.496 \\
13.496 \\
0 \\
0 \\
\hline
\end{tabular}

\begin{tabular}{|r|}
\hline Valor \\
Mercado \\
\hline 5.000 \\
7.000 \\
12.000 \\
-13.000 \\
-1.000 \\
\\
5.496 \\
0 \\
-6.000 \\
-1.000 \\
-1.504 \\
\\
0 \\
30.496 \\
13.496 \\
-4.000 \\
21.000 \\
\end{tabular}

\begin{tabular}{|c|c|}
\hline $\begin{array}{l}\text { Ajustes } \\
\text { Avaliatórios }\end{array}$ & $\begin{array}{r}\text { Ganhos/ } \\
\text { (-) Perdas }\end{array}$ \\
\hline Cálculo contábil & 0 \\
\hline Laudo engenharia & 2.000 \\
\hline & 2.000 \\
\hline Cálculo contábil & 0 \\
\hline Soma & 2.000 \\
\hline Cálculo contábil & 0 \\
\hline Cálculo contábil & -5.000 \\
\hline Cálculo contábil & 0 \\
\hline Cálculo contábil & -1.000 \\
\hline Soma & -6.000 \\
\hline Ganhos de capital & -4.000 \\
\hline \multicolumn{2}{|l|}{ Lucro normal } \\
\hline AOLvm & -1.000 \\
\hline i & $12 \%$ \\
\hline$L N=A O L_{v m} \cdot i$ & -120 \\
\hline
\end{tabular}

Lucro operacional

Receitas financeiras

Despesas financeiras

Resultado ativo nāo operacionais

Resultados não operacionais

Lucro antes IR

IR (40\%)

Lucro liquido
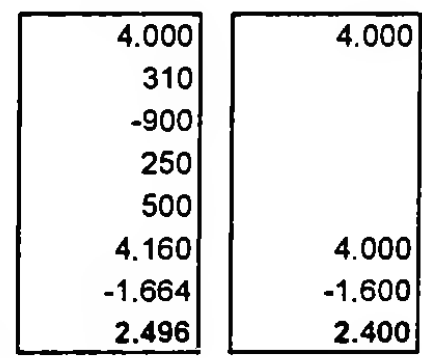

Goodwill
\begin{tabular}{|l|r|}
\hline LOL & 2.400 \\
LN & -120 \\
LAN = LOL - LN & 2.520 \\
\hline & $12,0 \%$ \\
\hline G = LAN / i & 21.000 \\
\hline
\end{tabular}

\begin{tabular}{|l|r|}
\hline Valor da sociedade & Mercado \\
\hline Valor do ativo operacional liquido a 12\% & 20.000 \\
Ativo não operacional liquido & -1.504 \\
$(-)$ IR ganhos de capital $(40 \%)$ & 0 \\
Goodwill & 0 \\
\hline Valor da sociedade & 18.496 \\
\hline Diferença avaliatória & \\
\hline
\end{tabular}

\begin{tabular}{|r|r|}
\hline Contábil & Individual \\
\hline-3.000 & -1.000 \\
4.496 & -1.504 \\
0 & 0 \\
0 & 21.000 \\
\hline 1.496 & 18.496 \\
\hline 17.000 & \\
\hline
\end{tabular}

\begin{tabular}{|l|r|}
\hline Demonstração da diferença avaliatória & -4.000 \\
\hline Ganhos de capital liquido & 21.000 \\
Goodwill & 17.000 \\
\hline Diferença & \\
\hline
\end{tabular}

Figura 9 Valor da sociedade inclusive goodwill, com ativo llquido operacional negativo e ajustes avaliatórios no ativo permanente operacional e contingēncias 


\section{CAPÍTULO 8 - DIFICULDADES E LIMITES PERICIAIS}

São de várias ordens as dificuldades enfrentadas pelos peritos em contabilidade, em função judicial, quando são nomeados pelos magistrados para apresentar laudo de apuração de haveres em processos de inventário ou de dissolução de sociedade. Aqueles, quando do rol de bens deixados pelo falecido constam quotas de sociedade limitada; estes, originários de dissidência societária ou por exclusão de sócios.

Podemos deparar com sociedades que, após o evento, permanecem em franca atividade; outras poderão ter paralisado os negócios. Há, até, casos em que são previstas, contratualmente, a dissolução e a liquidação da sociedade por morte de um dos sócios; entretanto, em vez de procederem à liquidação, os remanescentes resolvem continuar os negócios, gerando situação jurídica anômala.

Em alguns contratos sociais, é permitida a entrada dos herdeiros na sociedade; em outros, não se prevê tal possibilidade.

O contrato social, instrumento que regula a vida societária desse tipo de sociedade, contém, com muita freqüência, cláusula contratual para enfrentar situações de morte, ou dissidência de sócios; entretanto, normalmente, apenas determina seja elaborado balanço especial, sobre o qual serão apurados e pagos os haveres. Alguns avançam, definindo, a forma de pagamento aos herdeiros ou sócio dissidente.

Quando do evento, é comum os sócios remanescentes esquecerem essa obrigação societária, não elaborando as demonstraçōes contábeis para a data. Nunca vimos especificado, em contrato social, qualquer sanção que poderia ser aplicada aos responsáveis pelo não-cumprimento dessa regra contratual.

$E$, quando as elaboram, procuram, às vezes, minimizar os valores patrimoniais, de modo a reduzir os haveres a serem pagos, quando não esvaziam a 
sociedade, transferindo os negócios e/ou tecnologia e mesmo bens para outra sociedade, reduzindo o valor das quotas do sócio falecido, dissidente ou excluído.

Em raríssimos casos, constatamos a transcrição do balanço especial ou de determinação nos livros contábeis, o que, a teor do art. 12, do Código Comercial, deveria, em nosso entender, ser procedimento obrigatório em todos os eventos.

Em tempos recentes, muitas das sociedades limitadas sequer têm livros contábeis devidamente escriturados, especialmente as Microempresas (ME), e os peritos ainda têm que enfrentar questionamentos sobre negócios não registrados, ou seja, sobre o que se popularizou como caixa dois.

Da mesma forma, não há planos ou previsões orçamentárias quanto às perspectivas futuras dos negócios, que poderiam auxiliar no desenvolvimento dos estudos e cálculo do goodwill não adquirido. E, ainda que existam, os sócios remanescentes, por óbvio, não têm interesse em exibi-los, dificultando o trabalho pericial.

Como podemos vislumbrar, é uma situação complexa, às vezes caótica, com a qual depara o perito em contabilidade, quando do desenvolvimento de trabalhos periciais de apuração de haveres.

Como enfrentar alguns de tais óbices é o que propomos discutir a seguir.

\subsection{ALGUNS ASPECTOS OPERACIONAIS PERICIAIS}

Assim posta, a avaliação de sociedades organizadas sob a forma jurídica de sociedade limitada contemplará a valorização de todos os ativos pertencentes ou gerados pelo empreendimento, ou seja, ativos tangiveis e intangiveis.

Como complemento às diretrizes avaliatórias descritas no Capitulo 6, para avaliar uma sociedade em marcha, ou em funcionamento, dissolvida parcialmente, por decisão judicial, é condição necessária conhecer a estrutura e a qualidade dos ativos e passivos que serão objeto de avaliação. Enquanto sociedade em marcha, é empreendimento preexistente, com determinadas caracteristicas e qualidades, a 
serem levadas em consideração pelo perito em contabilidade no processo avaliatório.

O meio jurídico aceito e merecedor de fé em Juizo é o de o expert valer-se dos livros mercantis devidamente escriturados e respectivo suporte documental, que possuam as formalidades legais exigidas.

Daí decorre já o primeiro óbice, quando não existem livros mercantis devidamente escriturados, ou, se existirem, não tenham sido elaboradas as demonstraçōes contábeis especiais para a data do evento: óbito, ou declaração de dissidência, ou exclusão.

A data-base da avaliação será sempre o dia do evento, nem antes e tampouco depois. Por isso, a necessidade de demonstraçōes contábeis especiais, ou, mais precisamente, o balanço de determinação.

Os herdeiros têm direito ao reembolso da parcela que thes cabe da riqueza societária gerada e acumulada até o momento do evento, à medida que o sócio prémorto contribuiu com seu capital e esforço intelectual e gerencial para a formação do patrimônio societário existente. Do mesmo modo, o sócio dissidente ou excluído.

Por isso, demonstraçōes contábeis anteriores ou posteriores ao evento não se prestam à apuração dos haveres, por não refletirem, adequadamente, a situação patrimonial perseguida.

Demonstraçōes contábeis posteriores não se coadunam com os pronunciamentos dos tribunais, pois os sucessos ou fracassos posteriores, bem como eventuais manipulaçōes patrimoniais futuras, nāo alcançam o valor do reemboiso da quota social. Mesmo as demonstraçōes contábeis para a data do evento podem e são objeto de questionamento judicial, como se viu no Capitulo 5 que tratou da jurisprudência pátria.

Permeando todo o processo de avaliação dos ativos, especialmente do ativo permanente, não pode ser olvidado pelo perito em contabilidade o exame comparativo das demonstraçōes contábeis especiais com as de periodos anteriores a fim de obter segurança quanto à inexistência de danosas transferèncias 
patrimoniais levadas a termo pelos sócios remanescentes para esvaziar os haveres dos herdeiros, ou dos sócios dissidentes, ou excluidos.

Deparando-se com tais transferências, deverá noticiá-las em seu laudo, bem como anular seus efeitos na substância patrimonial da sociedade avalianda.

Atenção especial deve ser dada pelo perito em contabilidade à existência de contingências trabalhistas, tributárias ou mesmo comerciais. Deve desenvolver pesquisa junto à sociedade e seus advogados, inventariando açōes judiciais em curso, na data do evento, contra a sociedade e respectivos valores demandados. Deve também inteirar-se de eventuais açōes promovidas pela sociedade contra terceiros.

Demandas posteriores à data do evento devem ser consideradas apenas naquela parte que tenham vinculo ou origem anterior à data do evento.

Ponderadas as possibilidades de êxito ou derrota, deve o perito em contabilidade desenvolver procedimento avaliatório do evento, procedendo aos ajustes necessários na massa patrimonial.

\subsection{AUSÊNCIA DAS DEMONSTRAÇŌES ESPECIAIS DA DATA DO EVENTO}

Como vimos até agora, os procedimentos técnico-periciais são possíveis de ser realizados, à medida que pressupōem a existência de demonstrações contábeis especiais para a data do evento.

Nāo existindo referidas demonstraçōes, o que fazer?

Nesse caso, compete ao perito em contabilidade elaborar as demonstraçōes contábeis especiais para a data do evento, que servirāo de base para a apuração de haveres determinada pelo magistrado.

Para tanto, deve municiar-se de pelo menos dois balancetes mensais: o do mês anterior e o do mès do evento.

Partindo dos dados consignados no balancete do mês anterior à data do evento, adiciona a eles as transaçōes realizadas até a data do evento; para as 
despesas mensais, como, por exemplo, despesas de pessoal ou depreciação, considera os valores do mês do evento, proporcional aos dias decorridos, entre o primeiro dia do mês e o dia do evento. No que se refere às receitas e compras de insumos do mês, pode valer-se dos registros fiscais, considerando o acumulado do mês até a data do evento.

Outra fonte de exame muito útil é o livro razão, se ele registrar as transaçōes diariamente, em especial, para a obtençăo dos saldos dos ativos e passivos acumulados até a data do evento.

Já quanto ao valor contábil dos estoques na data do evento, conhecido o custo dos produtos ou das mercadorias vendidas do mês do evento, pode, considerando a proporcionalidade daquele custo, calcular o referido valor. $O$ ideal será verificar se a sociedade tinha à época controle e inventário permanente e proceder aos levantamentos necessários.

Feitas as agregaçōes das receitas e despesas do mês até o dia do evento aos valores acumulados e constantes do balancete do mês anterior, deve calcular os impostos e as contribuiçōes incidentes sobre o resultado acumulado apurado, provisionando os respectivos valores.

Elaboradas as demonstraçōes financeiras especiais pelo Perito Contábil, os procedimentos avaliatórios periciais percorrem as mesmas trilhas indicadas anteriormente.

\subsection{INEXISTÊNCIA DE LIVROS MERCANTIS ESCRITURADOS}

O que suscita questão técnica mais delicada è a relativa à ausência ou inexistência de contabilidade regularmente processada, realidade fática que envolve um sem-número de sociedades, especialmente as denominadas microssociedades limitadas.

Em outras palavras, como avaliar uma sociedade, sem livros mercantis devidamente escriturados, cuja apuração de haveres mereça credibilidade judicial? 
Que caminhos técnicos podem ser percorridos pelo perito em contabilidade a fim de compor os ativos e passivos da sociedade, que possibilitem oferecer apuração de haveres em determinado momento passado, não formalizados em livros?

Não podemos olvidar que os trabalhos periciais são sempre desenvolvidos em época posterior ao evento $e$, às vezes, muito tempo já se passou entre a data do evento e a realização do trabalho pericial contábil de apuração dos haveres. Pode até suceder que a sociedade já não exista de fato.

Sāo situaçōes para as quais não temos respostas ou procedimentos acabados. Podemos apenas alinhavar algumas tentativas de resposta. Alguns caminhos podem ser explorados, entretanto, sem qualquer garantia de êxito.

O profissional deve compulsar o contrato social e as respectivas alteraçōes, os documentos fiscais de compra e venda, as folhas de pagamento, os livros fiscais de entradas e saidas, a declaração de rendimentos da pessoa juridica, as escrituras de venda e compra, entre outros, bem como proceder a inventário dos bens, direitos e obrigaçōes, na data dos exames periciais, elaborando, em seguida, o balanço de determinaçāo dos ativos e passivos inventariados, e apurando o patrimônio líquido, por diferença.

É claro que os bens inventariados deverão ser avaliados pelos mesmos procedimentos já anteriormente relatados, mas dentro das possibilidades das partes e considerando sua materialidade.

Muito embora esta seja, talvez, a única possibilidade técnica avaliatória para a ausència de livros escriturados, ela esbarra em dois aspectos importantes, um de natureza juridica, outro de possibilidade prática:

a. natureza jurídica: o balanço de determinação elaborado pelo perito em contabilidade, com base no inventário dos ativos e passivos, não representa a situaçāo patrimonial na data do evento, mesmo porque os negócios da sociedade podem ter prosperado ou diminuido, entre aquela data e a dos levantamentos periciais; 
b. possibilidade prática: a técnica avaliatória depende, por outro lado, da continuidade dos negócios da sociedade e da existência de alguns livros e documentos que possam ser objeto de exame pericial.

O primeiro óbice poderá ser contornado, aceitando-se a apuração de haveres dai surgida como se fora por arbitramento, dispositivo juridico contido no Código de Processo Civil (arts. 606 e 607), que, embora previsto para a fixação de valor em Execução de Sentença, poderia, em nosso entender, ser adaptado à espécie.

Para tanto, observada pelo expert tal situação, será o caso, mediante petição, submetido ao crivo do magistrado, que deliberará.

É pertinente que os haveres assim apurados devam ser levados para moeda de poder aquisitivo da data do evento, descontados das taxas de crescimento do setor econômico em que atua a sociedade avalianda, ou, na ausência destas, daquelas gerais da economia, excluindo-se, de forma indireta, prováveis variaçōes patrimoniais havidas após a data do evento.

Se nenhum desses procedimentos for possivel de ser adotado, só resta ao perito socorrer-se do contrato social e respectivas alteraçōes, registradas no respectivo órgão de comércio, e das receitas consignadas na declaração de rendimentos da pessoa juridica, calculando os haveres considerando a participação monetária do sócio no capital social da sociedade como sendo seus haveres, devidamente, atualizados para a data do evento, mesmo porque eventuais lucros auferidos ao longo de sua existencia ou foram capitalizados ou distribuidos de fato. Isto se constatar que a sociedade ainda tem existència jurídica e de fato.

Ao contrário, se constatar que a sociedade ainda existe juridicamente, mas não de fato, e não conseguindo localizar qualquer tipo de ativo a ela pertencente, deve informar ao magistrado, por meio de seu laudo pericial contábil que os haveres do sócio inexistem. 


\section{CONCLUSÕES}

A avaliação de sociedades em processos judiciais de dissolução societária parcial para efeito de apuração de haveres tem suporte nos Principios e Normas Brasileiras de Contabilidade vigentes, adaptados a essa espécie avaliatória.

Como amplamente demonstrado ao longo do presente trabalho as possibilidades avaliatórias aplicáveis a sociedades em marcha envolvem conceitos, modelos e métodos avaliatórios variados. Uns compativeis com a espécie pericial, outros não.

\section{- Sistema CONCEITUAL CONTÁBIL de APURAÇÃo de HAVERES}

O sistema ou modelo conceitual contábil compativel com a avaliação judicial de sociedades e respectiva apuraçāo de haveres è composto dos seguintes elementos:

$1^{\circ}$ O acervo patrimonial é avaliado a preços de mercado, espécie da categoria contábil valores de saida, ou valores líquidos de realização.

$2^{\circ}$ A precificaçāo dos elementos patrimoniais é realizada, considerando um processo de liquidação ordenada, ou seja, os preços adotados no processo avaliatório são aqueles que se obteria no mercado em condiçōes operacionais normais.

$3^{\text {o }}$ Os elementos patrimoniais têm liquidez; podem ser transformados em numerário prontamente.

$4^{\circ}$ - goodwill corresponde à capacidade que determinada sociedade possui de gerar lucros acima do normal, como defendem os juristas compulsados; corresponde ao sobrevalor, ou efeito sinérgico defendido por MONOBE. 
50 Lucro normal corresponde ao rendimento (lucro) que o ativo operacional líquido, a valores de mercado apurado e consignado no balanço de determinação, não incluido o goodwill, pode gerar se aplicado a uma taxa de juros (i) correspondente ao custo do capital próprio.

6- O custo do capital próprio corresponde, para fins de avaliação judicial, à taxa máxima de juros permitida por lei que os particulares podem ajustar em seus negócios; isso equivale a doze por cento ao ano, conforme legislação vigente.

\section{- SISTEMA OPERACIONAL CONTÁBIL DE APURAÇÃo DE HAVERES}

O sistema operacional que suporta o modelo conceitual materializa-se no balanço de determinação elaborado pelo perito em contabilidade, em função judicial, o qual é utilizado na determinação do montante dos haveres que cabe ao sócio retirante ou aos herdeiros do sócio pré-morto.

A elaboração do balanço de determinação envolve três estágios técnicos distintos.

O primeiro estágio corresponde aos ajustes técnicos realizados pelo perito judicial para tornar compativel as demonstraçōes contábeis da data do evento aos Principios Fundamentais de Contabilidade e às Normas Brasileiras de Contabilidade.

O segundo estágio refere-se aos ajustes avaliatórios realizados pelo perito judicial, de modo que sejam reconhecidos todos os efeitos originários das avaliaçōes dos itens patrimoniais a valores de mercado, em confronto com os valores contábeis, considerando, inclusive, as provisōes tributárias sobre os ganhos de capital porventura apurados.

Toda e qualquer variação patrimonial positiva reconhecida no processo avaliatório, é essencialmente ganho de capital e, por isso, sujeita à tributaçāo federal vigente à época do evento; portanto, è de rigor a constituição de provisões compativeis com o referido ganho. A não-constituição acarreta para a sociedade avalianda a assunção de todo o ônus tributário, beneficiando, indevidamente, o sócio retirante (dissidente ou excluido) ou os herdeiros do sócio pré-morto; os 
haveres apurados são superavaliados, causando descapitalização indevida à sociedade e prejuizo aos sócios remanescentes.

O estágio derradeiro corresponde ao estudo da constatação ou não da existência do goodwill. A universalidade dos bens contempla todos os ativos tangiveis ou corpóreos e intangiveis ou incorpóreos. O goodwill, um dos ativos intangiveis, integra a universalidade dos bens; por isso, os pronunciamentos judiciais determinam sua inclusão no balanço de determinação.

O goodwill, entendido como a mensuração do efeito sinérgico, é calculado adotando-se a fórmula a seguir:

$$
\mathbf{G}=\operatorname{LAN} / i \text {, }
$$

onde:

$$
\begin{array}{ll}
G \quad=\text { goodwill } \\
\text { LAN }=\text { lucro acima do normal } \\
\mathrm{i} \quad=\text { custo do capital próprio }
\end{array}
$$

Finalizado o balanço de determinação, é chegado o momento de calcular o montante dos haveres devidos. Esse montante resulta da multiplicação do valor do patrimônio liquido consignado no balanço de determinação pelo percentual de participação do sócio retirante ou pré-morto no capital social da sociedade avalianda.

Ao montante dos haveres apurados são acrescidos eventuais créditos ainda nāo liquidados e deduzidos eventuais débitos de responsabilidade do sócio retirante ou pré-morto. Apurado o saldo líquido, procede-se à atualização monetária, desde o evento até a época do laudo, por indexadores aceitos pelos tribunais; em seguida, procede-se ao cálculo dos juros se já fixados na sentença ou acórdão. 
- APURAÇÃo de haVERES EM SOCIEDADES SEM ESCRITURAÇÃo MERCANTIL

Procedimentos, métodos e técnicas de natureza pericial contábil de apuração de haveres propostos, quando inexistente escrituração mercantil e a sociedade avalianda permanece operando, são os que seguem:

$1^{0}$ Compulsar o contrato social e respectivas alteraçōes, os documentos fiscais de compra e venda, folhas de pagamento, livros fiscais de entradas e saidas, extratos bancários, contratos de locação, contratos de franshising, certidōes judiciais, declaração de rendimentos da pessoa jurídica, escrituras de venda e compra, entre outros.

$2^{\circ}$ Proceder a inventário dos bens, direitos e obrigaçōes, na data dos exames periciais, elaborando, em seguida, o balanço de determinaçăo dos ativos e passivos inventariados, apurando-se o patrimônio líquido, por diferença.

$3^{0}$ Os bens inventariados são avaliados pelos mesmos procedimentos já anteriormente relatados, mas dentro das possibilidades das partes e considerando sua materialidade.

$4^{\circ}$ Os haveres apurados são deflacionados, pelos indexadores aceitos pelos Tribunais, para moeda de poder aquisitivo da data do evento, descontadas as taxas de crescimento do setor econômico em que atua a sociedade avalianda, ou na ausência dessas, adotamos aquelas gerais da economia, excluindo-se, de forma indireta, prováveis variaçōes patrimoniais havidas após a data do evento.

Por absoluta falta de elementos contábeis históricos fica prejudicado qualquer estudo relativo ao goodwill de sociedade sem escrituração mercantil.

Pode ser assim o sistema conceitual e operacional contábil de apuração de haveres em processos judiciais. 
PROPOSTA DE MODELO

de laudo pericial contábil

E ROTEIRO DE APURAÇÃO DE HAVERES 


\section{INTRODUÇÃO}

O laudo pericial contábil de apuração de haveres deve conter determinadas características compativeis com o conteúdo que the é peculiar.

Algumas são semelhantes às de outros tipos de laudo, como, por exemplo, a apresentação do laudo, as consideraçōes introdutórias, ou preliminares, as considerações finais, ou conclusões técnicas, e o encerramento.

Aspectos diferentes de outros tipos de laudo são os relacionados com a apuração de haveres propriamente dita. Para tanto, é necessário apresentar esse conteúdo especifico de forma ordenada e em conformidade com o processo avaliatório pericial judicial.

Resumindo esse tipo de laudo, temos que seu conteúdo pode ser assim ordenado:

\section{Das considerações preliminares}

1.1 Aspectos gerais

1.2 Diligências

1.3 Procedimentos técnicos adotados

1.4 Responsabilidade profissional

\section{Da apuração de haveres}

2.1 Ajustes técnicos

2.2 Ajustes avaliatórios

2.3 Balanço de determinação 
2.4 Haveres apurados

3 Das respostas aos quesitos

3.1 Dos requerentes

3.2 Dos requeridos

4 Das consideraçōes finais

5 Do encerramento

Havendo anexos e documentos, eles sāo juntados em seguida.

A seguir, são ordenados e comentados os vários tópicos do modelo de laudo pericial contábil de apuração de haveres proposto. 


\section{I - ENDEREÇAMENTO E APRESENTAÇÃO DO LAUDO}

Todo e qualquer laudo pericial contábil judicial é sempre dirigido ao Juiz da Vara que nomeou o perito. A peça técnica é dirigida ao cargo e não à pessoa do juiz, mesmo porque este pode ser transferido, promovido ou aposentar-se.

É o que se denomina de endereçamento e apresentação do laudo à autoridade judiciária respectiva.

É necessário que do laudo constem a identificação e a categoria profissional do expert, o número de registro no Conselho Regional de Contabilidade, o nome das partes, o tipo de ação e o número do processo.

É, por sua vez, necessário deixar espaço, em torno de $10 \mathrm{~cm}$, entre o endereçamento e o início do texto, de modo a possibilitar ao magistrado apor seu despacho de ciência do laudo às partes.

A seguir, ilustração da página de endereçamento e apresentação do laudo, seguida do indice dos tópicos que o compōem. 


\section{EXMO. SENHOR DR. JUIZ DE DIREITO DA ....' VARA CÍVEL DO FORO DA.}

(NOME DO PERITO), bacharel em Ciências Contábeis registrado no $C R C$-.... sob o n Perito nomeado nos autos do processo $n^{\circ}$ XXXXYYY - EXCLUSÃO DE SOCIO' - em que são partes:

\section{FULANO 1....... E OUTROS}

Requerentes

e

\section{BELTRANO 1....... E OUTRO}

Requeridos

após ter cumprido as devidas diligências, verificado e examinado 0 que era necessário e estava disponivel, procedimentos exigidos para o fiel cumprimento do honroso mandato, apresenta o resultado de seu trabalho, consubstanciado no seguinte
L A U D O
P E I I I A L
C O N T Á B I L

Poderá ser "DISSOLUÇÃO DE SOCIEDADE". 


\section{ÍNDICE}

Apresentaçāo

indice

1. Das consideraçōes preliminares

1.1 Aspectos gerais

1.2 Diligências

1.3 Procedimentos técnicos adotados

1.4 Responsabilidade profissional

2. Da apuração dos haveres

2.1 Ajustes técnicos

2.2 Ajustes avaliatórios

2.3 Balanço de determinaçāo

2.4 Haveres apurados

3. Das respostas aos quesitos

3.1 Dos requerentes

3.2 Dos requeridos

4. Das consideraçōes finais

5. Do encerramento

ANEXOS:

(Identificar, um a um, todos os anexos ou planilhas elaborados pelo perito para ilustrar ou suportar os valores e raciocinios técnicos desenvolvidos.)

\section{DOCUMENTOS:}

(Identificar, um a um, todos os documentos colhidos quando das diligências e utilizados para suportar os valores e raciocínios técnicos contidos no laudo e juntados.) 


\section{II - DO TÓPICO DAS CONSIDERAÇÕES PRELIMINARES}

O primeiro tópico do conteúdo do laudo pericial contábil de apuração de haveres pode denominar-se Das consideraçōes preliminares, ou Da introdução. É a parte introdutória, relativa ao relatório pericial.

Pode ser dividido em alguns subtópicos.

No primeiro subtópico, é descrito, sucintamente, o pedido formulado pelo proponente da ação constante da Inicial. Em seguida, são relatados os fatos descritos e sua contestação, aspectos fundamentais para a identificação da controvérsia levada a Juizo ou Tribunal Arbitral e, conseqüentemente, trazemse à luz os contornos e limites do trabalho pericial. Leitura atenta dos autos do processo permite extrair os aspectos centrais da demanda.

Como segundo subtópico, são descritas as diligências realizadas pelo perito, os principais momentos do desenvolvimento do trabalho de campo, referenciando, inclusive, o respectivo termo, prova essencial de que o perito realizou a diligência e que requereu a exibição de determinados livros e documentos, destacando-se eventuais ocorrências que, porventura, tenham sucedido, tais como: (a) não-exibição de documentos; (b) ausência de escrituração contábil; (c) livros sem registro no órgão competente etc.

No terceiro subtópico, são descritos os principais procedimentos técnicos adotados pelo perito, bem como os exames efetuados para a solução das questões técnicas.

No último subtópico, são destacados alguns limites quanto à responsabilidade profissional do perito no desenvolvimento de seu trabalho técnico, reportando-se aos dispositivos das Normas Técnicas de Perícia Contábil e Funcionais do Perito que abordam essa questão.

Vejamos a ilustração. 


\section{DAS CONSIDERAC̣ÕES PRELIMINARES}

\subsection{Aspectos gerais}

Fulano 1, Fulano 2 e Indústria de Produtos Técnicos XYZ Ltda. moveram a presente Ação de Exclusão de Sócios ${ }^{2}$ perante Beltrano 1 e Beltrano 2, cujo objetivo perseguido foi o de obter a decretação da exclusão dos sócios em segundo lugar nominados, cumulada com a correspondente apuração dos haveres em favor dos sócios excluídos, ora Requeridos.

Os Requeridos oferecem a Contestação de fls. .... e seguintes.

Superadas as várias etapas processuais, o magistrado decide a lide, exarando a sentença de fls assim:

"Ante o exposto, julgo procedente a ação e, em conseqüencia, declaro excluidos da empresa INDÚSTRIA DE PRODUTOS TÉCNICOS XYZ LTDA. os sócios Beltrano 1 e Beltrano 2, devendo para tanto ser apurados seus haveres, na forma da lei."

As partes recorrem ao Egrégio Tribunal de Justiça do Estado de (nome do Estado), tendo aquela Corte mantido a decisão de $1^{\circ}$ grau, como se vê no V. Acórdão de fls. .... e seguintes.

Em cumprimento ao Acórdão, as partes requerem a nomeação de Perito para a elaboração da apuração dos haveres.

Assim, é determinada pelo MM. Juizo a realização de prova pericial contábil, como se về às fls. ..... Para tanto, è nomeado este Perito. As partes oferecem quesitos: fls. ...... (Requerentes) e fls. ..... (Requeridos) e indicam Assistentes Técnicos.

\footnotetext{
2 Em se tratando de açđ̃o de dissolução de sociedade, é necessário adaptar este trecho.
} 


\subsection{Diligências}

Após a organizaçāo e o planejamento do trabalho pericial, que foi suportado pela leitura dos autos e exame e verificação da documentação juntada, solicitou-se à Requerente $X Y Z$, por meio de seu assistente técnico, que colocasse à disposição da Pericia livros e documentos que se especificou conforme Termo de Requerimento de Exibição de Livros e Documentos, anexo กํ.......

Informado que os livros e documentos estavam à disposição, o signatário procedeu a várias diligências, tendo formalizado a realizada no dia como se vê no respectivo Termo de Diligência, anexo $n^{\circ} \ldots .$.

Os livros compulsados foram aqueles especificados no anexo $n \circ \ldots .$.

Constatada a existência de imóveis no acervo patrimonial da sociedade avalianda, requereu-se, como se vê na petição de fls. ......., a nomeaçāo de perito engenheiro ${ }^{3}$ para a oferta de laudo de avaliação dos referidos imóveis.

Nomeado perito engenheiro às fis. ........ Quesitos e assistentes técnicos às fls. Laudo Oficial juntado às fls. e seguintes.

Laudo de engenharia concordante do assistente técnico dos requeridos juntado às fls. e seguintes. Laudo de engenharia parcialmente discordante do assistente técnico dos requerentes juntado às fis. seguintes.

No que se refere ao desenvolvimento técnico do trabalho pericial contábil, a Pericia oferece, a seguir, a descrição dos principais procedimentos adotados.

\subsection{Procedimentos técnicos adotados}

O trabalho pericial contábil, tendo presente o inteiro teor da $R$. Sentença de fls., foi desenvolvido, em seus aspectos mais relevantes, assim:

3 Na maioria dos casos, a nomeação de perito engenheiro é concomnitante à nomeação do perito eın contabilidade, e é, portanto, desnecessário o contador solicitar a providência sugerida. 
a. leitura atenta de tudo o que consta dos autos;

b. requisiçāo da exibição de livros e documentos pertencentes à empresa avalianda;

c. todos os procedimentos técnicos aplicados no desenvolvimento da apuração de haveres vão descritos em pormenor, na seção seguinte;

d. por fim, todos os demais procedimentos técnicos necessários à apuração dos haveres e às respostas aos quesitos formulados e de elaboraçāo do presente Laudo Pericial Contábil.

\subsection{Responsabilidade profissional}

No desenvolvimento dos trabalhos periciais, foram aplicados os principios da investigaçāo pericial e demais procedimentos, na extensāo de sua viabilidade técnica em confronto com os controles das partes, bem como com documentos juntados aos autos e aqueles exibidos à Pericia quando das diligèncias, nos limites técnicos preconizados pela NBC T 13 - Normas de Pericia Contábil, aprovada pelo Conselho Federal de Contabilidade.

Outrossim, sāo inassumiveis responsabilidades sobre documentos controversos, se suscitados e sobre matéria juridica, excluidas destas as implicitas para o exercicio pleno da função profissional na elaboração deste Laudo Pericial Contábil, precipuamente estabelecidas em leis, códigos e regulamentos próprios, em especial as contidas na NBC P 2 - Normas Profissionais de Perito, aprovadas pelo Conselho Federal de Contabilidade.

Posto isto, passa-se a seguir a oferecer a apuração de haveres determinada pelo MM. Juizo. 


\section{III - DO TÓPICO DA APURAÇÃO DOS HAVERES}

Este é o tópico central do laudo pericial contábil de apuração de haveres.

O primeiro momento é o da verificação da existência ou não das demonstrações contábeis especiais. O falecimento de sócio componente de sociedade limitada ou dissidência societária neste mesmo tipo de sociedade, por força de cláusula contratual, obriga os sócios remanescentes a prepararem demonstraçōes contábeis para a data do evento. Todavia, nem sempre tal procedimento foi cumprido, o que, em sua ausência, leva o perito a proceder a sua preparação, em conformidade com Principios Fundamentais de Contabilidade e respectivas Normas.

Dois sāo os niveis de ajustes desenvolvidos pelo perito em contabilidade: técnicos e avaliatórios. Aqueles refletem ajustes de natureza técnica, estes são originários do processo avaliatório.

Com base nas demonstraçōes contábeis disponiveis, o perito efetua os ajustes relativos ao cumprimento dos Principios Fundamentais de Contabilidade, operacionalizados por meio das Normas Brasileiras de Contabilidade. Isto se faz necessário, pois nem sempre as demonstraçōes disponibilizadas ao perito resultam da aplicação correta das citadas Normas.

Por outro lado, ele deve também averiguar se as demonstraçōes contábeis refletem adequadamente a realidade fisico-contábil patrimonial da sociedade avalianda, dando consistència aos saldos das contas, o que poderá ensejar determinados ajustes contábeis em decorrência de erros ou de ausência de escrituração de algumas operaçōes.

Cuidado especial deve ter o perito a fim de evidenciar eventuais desvios patrimoniais perpetrados pelos sócios remanescentes. Para tanto, é importante desenvolver exame técnico comparativo das demonstraçōes contábeis anteriores às especiais, cotejando os niveis de receitas, das despesas, o 
movimento das contas de ativo permanente, de financiamentos bancários e demais obrigações societárias.

Garantida a consistência dos valores patrimoniais consentâneos com as normas e procedimentos contábeis, é o momento de partir para os procedimentos avaliatórios propriamente ditos. Os ajustes avaliatórios vão refletir o reconhecimento da massa patrimonial a valores de mercado e seus reflexos tributários, tudo refletido no balanço de determinação.

Os ajustes avaliatórios seguem os procedimentos amplamente descritos no Capítulo 6.

Os itens monetários que envolvem disponibilidades, créditos e obrigaçōes são avaliados como descrito na seção 6.3.1, Avaliação de itens monetários.

Os itens não monetários, considerados como tais estoques, investimentos permanentes, imobilizado, diferido, resultados de exercicios futuros, sāo avaliados observando-se os procedimentos descritos em 6.3.2, Avaliaçăo de itens não monetários.

$\mathrm{Na}$ seqüência, são estimadas e calculadas as contingências de qualquer natureza conhecidas, como descrito na seção 6.3.3, Contingências.

A constatação da existência de goodwill, ou seja, a capacidade que a sociedade avalianda possui de gerar lucros acima de determinado patamar considerado como normal para o tipo de sociedade que está sendo objeto da avaliação, ou de sobrevalor, 'como entendido pelos comercialistas, é evidenciada e calculada como proposto no Capitulo 7, Avaliação do goodwill em apuração de haveres.

Apurados ganhos de capital originários da diferença entre os valores de mercado e os valores contábeis, procede-se ao cálculo das provisões tributárias respectivas, obedecida a legislação vigente na data-base da avaliação.

Efetuados todos os ajustes originários do processo avaliatório, é chegado o momento de oferecer o balanço patrimonial da sociedade avalianda, ou seja, 
- balanço de determinação, evidenciando todos os ajustes avaliatórios levados a efeito, destacando-se o valor apurado do patrimônio líquido da sociedade.

Constando dos autos do processo avaliaçōes imobiliárias divergentes, por exemplo, o perito engenheiro apura determinado valor, enquanto os assistentes técnicos apuram valores divergentes, isso obriga o perito em contabilidade a oferecer balanços de determinação diferenciados, que contemplem os valores divergentes, já que nāo lhe compete optar por um deles. Isto é mister do magistrado.

. É com base no patrimônio líquido consignado no balanço de determinação que se apuram os haveres, assim: o patrimônio liquido apurado é dividido pela totalidade das quotas representativas do capital social, obtendo-se o valor unitário de uma quota; em seguida, multiplica-se a quantidade de quotas pertencentes ao sócio dissidente, excluido ou pré-morto pelo valor unitário de cada quota, apurando-se os haveres devidos na database da avaliação.

Os haveres serāo constituidos do valor apurado para as quotas de capital, adicionado de eventuais valores a receber a título de empréstimos concedidos ou de pró-labore a receber não liquidados até a data do evento, ou, ainda, subtraidos de valores que porventura tenham sido emprestados pela sociedade ao sócio, que não foram devolvidos até a data do evento.

Por derradeiro, os haveres são atualizados monetariamente, desde a data-base da avaliação até a época do laudo pericial contábil pelo indexador aceito pelo Poder Judiciário do lugar em que a sociedade avalianda tem sua sede. Havendo já definição quanto aos juros, estes são calculados pela taxa fixada em sentença sobre os haveres atualizados e na forma determinada.

A seguir, apresentamos ilustração dessa parte do laudo pericial contábil. 


\section{DA APURAC̣ÃO DOS HAVERES}

Para cumprir a determinaçāo do MM. Juizo, e em face da ausência das demonstrações financeiras para a data de (data do evento), foi necessário que a Perícia desenvolvesse diversos procedimentos técnicos e avaliatórios, que são a seguir relatados.

\subsection{Ajustes técnicos}

Compulsados os livros e documentos contábeis da Requerente $X Y Z$, onde estão consignadas as operações da empresa até (mês anterior) e (mês do evento), a Perícia constatou que as contas patrimoniais e de resultado apresentavam os saldos devedores e credores constantes dos balancetes que ora se oferece, sob a forma dos documentos $n^{\text {os }}$... e .... cujos valores foram transcritos para o anexo $n^{\circ}$.....

Feito o exame dos saldos das contas aí consignados, constatou-se que determinados procedimentos técnicos contábeis somente eram realizados ao final do exercício social, como é o caso da correção monetária de balanço, entre outros, o que ensejou ajustes técnicos para a data-base do evento.

Constatou-se ainda que alguns saldos exigiam ajustes para melhor refletirem a situação de cada um deles, naquela data, o que foi feito.

Com referência ao resultado económico do mês de (mês do evento), até o dia (dia do evento), adotou-se como critério técnico reconhecer $r_{3}$ proporcionalmente, as receitas $e$ as despesas mensais, considerando .....\% para o mês em referencia; no que se refere ao custo de vendas, adotou-se o percentual sobre a receita líquida do exercício social encerrado em (ano do evento). 
Outros ajustes técnicos decorreram do Princípio Contábil da Competência de Exercícios, como é o caso, por exemplo, das Provisōes para Férias, $13^{\circ}$ Salário e respectivos encargos trabalhistas e da Contribuição Social e Provisão para Imposto de Renda sobre o Lucro apurado até (dia do evento)

Todos os procedimentos técnicos desenvolvidos pela Perícia estão demonstrados nos seguintes anexos:

- Anexo no

Correção monetária de balanço: ativo permanente.

- Anexo $n^{\circ}$

Despesas de depreciação mensal.

- Anexo $n^{\circ}$

Correçāo monetária de balanço: patrimônio líquido.

- Anexo no

Valores nominais do BTNf utilizados na correção monetária de balanço.

- Anexo no

Demonstraçāo do cálculo da provisão para devedores duvidosos.

- Anexo no

Demonstração e cálculo das provísōes para férias, $13^{\circ}$ salário e respectivos encargos, tendo por base a folha de pagamento de (mês do evento), doc. $n^{\circ} \ldots$

- Anexo no

Ajustes nas contas de aplicaçōes financeiras.

- Anexo $n^{0}$

Corresponde ao balancete de (dia do evento), incluidos todos os ajustes técnicos efetuados. 
Efetuados todos os ajustes técnicos necessários retro-relatados, finalmente, houve condições técnicas de elaborar as demonstrações financeiras em conformidade com as normas técnicas e a boa técnica contábil para a data de (dia do evento), como evidenciado no anexo $n^{\circ}$... e aqui apresentado na forma resumida a saber:

\section{BALANÇO PATRIMONIAL EM (DATA-BASE)}

ATIVO

CIRCULANTE

REALIZÁVEL A LONGO PRAZO

PERMANENTE

TOTAL

PASSIVO

CIRCULANTE

EXIGIVEL A LONGO PRAZO

PENDENTE

PATRIMONNIO LIQQUIDO CONTÁBIL

Posto isto, do ponto de vista técnico, é sobre esse balanço patrimonial que serão desenvolvidos todos os ajustes e procedimentos avaliatórios, com o objetivo de se obter o valor real e justo do patrimônio liquido da sociedade $X Y Z$, mediante balanço de determinação, que vão a seguir relatados.

\subsection{Ajustes avaliatórios}

Tomando-se as demonstraçōes financeiras especiais de (dia do evento), devidamente corrigidas pelos ajustes técnicos relatados no tópico anterior, é necessário, para se obter o valor justo do patrimônio líquido real, levar em consideração as avaliaçōes de engenharia dos imóveis, valores de mercado de outros itens patrimoniais, bem como outros ajustes avaliatórios relativos a perdas e ganhos monetários, bem assim o que se refere ao goodwill. 
Assim, a Pericia desenvolveu os seguintes ajustes avaliatórios:

- Anexo $n^{2}$

Ajustes avaliatórios relativos aos imóveis (edifícios e terrenos) pertencentes à sociedade avalianda originários da confrontação dos valores apurados e consignados no laudo pericial oferecido pelo perito engenheiro, com os valores contábeis apurados pela Perícia Contábil.

Cabe observar que não se considerou cerca de ....... $\mathrm{m}^{2}$ de área construida, pois, embora avaliada, trata-se de construçōes realizadas após a data de (dia do evento); portanto, fora dos haveres dos sócios excluídos.

- Anexo $n^{\circ}$

Neste anexo, está demonstrada a avaliação e o respectivo ajuste avaliatório dos direitos de uso de linhas telefônicas comerciais pertencentes à sociedade avalianda.

As fontes de consulta utilizadas foram as informações colhidas junto à Bolsa de Telefones e ao Jornal da cidade de - documentos $n^{\circ} s$... a ... e as contas telefônicas entregues à Perícia, documento $n^{\circ}$...

- Anexo no

São especificados os ajustes avaliatórios dos veículos pertencentes à sociedade.

Os critérios de avaliação levaram em consideração os preços de mercado divulgados pelo Jornal ......... edição de (dia do evento, ou o mais próximo), documento $n^{\circ} \ldots$

Para os caminhōes (marca), por ausência de cotação de mercado, utilizou-se o próprio valor de venda praticado pela sociedade avalianda, trazido para a data-base, deduzindo-se a parcela de depreciação, esta calculada até o dia (data do evento). A documentação comprobatória das vendas realizadas vai juntada sob a forma dos documentos $n^{\circ} s$... a ... 
- Anexo nำ

Neste anexo, são relacionados os compromissos com fornecedores na data de (data do evento), cujos valores foram utilizados no anexo $n^{\circ} \ldots$ para efeito de cálculo dos ganhos monetários neste item patrimonial.

- Anexo no

São evidenciados os ganhos monetários mensurados pelo indexador descrito no anexo $n^{\circ}$..., confrontando-se o poder aquisitivo da moeda nas datas de vencimento dos compromissos com fornecedores com aquele do dia (data do evento). Procedeu-se como descrito por se desconhecer o custo financeiro embutido.

- Anexo $n^{\circ}$

Neste anexo, são relacionadas as duplicatas a receber de clientes na data de (data do evento), cujos valores foram utilizados no anexo $n^{\circ}$... para efeito de cálculo das perdas monetárias neste item patrimonial.

- Anexo no

São evidenciadas as perdas monetárias mensuradas pelo indexador descrito no anexo $n^{0}$..., confrontando-se o poder aquisitivo da moeda nas datas de vencimento das duplicatas a receber de clientes com aquele do dia (data do evento). Procedeu-se como descrito, por não ter sido informado pela sociedade avalianda qual o custo financeiro embutido nas operações a prazo.

- Anexo $n^{0}$

São demonstrados os ganhos de estocagem de matérias-primas, embalagens e produtos acabados, confrontando-se a valorização dos estoques conforme listagens de inventário da empresa avalianda com o valor estimado dos estoques finais em (data do evento). A sociedade năo teve condiçōes de informar os preços de mercado para reposiçāo das matériasprimas e embalagens. Os produtos acabados foram valorizados por seu preço de venda, deduzido das despesas inerentes e margem de lucro. 
- Anexo no

São apresentadas as demonstrações financeiras da $X Y Z$ dos exercícios sociais (datas das demonstrações), a valores nominais, conforme documentos $n^{0 s} \ldots$ a ...

- Anexo no

Neste anexo, são evidenciados os elementos patrimoniais dos exercícios sociais de (datas das demonstrações), em moeda constante, tendose utilizado como elemento homogeneizador a evolução dos indices oficiais de correçāo monetária de balanço especificados no anexo $n^{\circ}$....

- Anexo $n^{\circ}$

São apresentados os indexadores oficiais utilizados pela sociedade avalianda para cálculo da correção monetária de balanço, os quais foram utilizados para equalizar o poder aquisitivo dos valores patrimoniais declarados nas demonstraçōes financeiras dos exercícios sociais de ...... a ...... para moeda constante de 31 de dezembro de ........

- Anexo $n^{\circ}$

Este anexo é todo dedicado ao estudo da constatação da existência ou não do goodwill, que a sentença denominou de fundo de comércio.

Para o efeito, partindo-se dos lucros operacionais líquidos, em moeda constante, apurados no anexo $n^{\circ}$..., procedeu-se ao cálculo do lucro operacional liquido médio histórico observado nos exercícios sociais anteriores de ..... a ......

Considerou-se como lucro normal o resultado da multiplicação do ativo operacional líquido, a valores de mercado, consignado no balanço de determinação, pela taxa de ...\%. Referida taxa corresponde à taxa de juros fixada no contrato social para efeito de reembolso aos sócios e é assumida como o custo do capital próprio. Compulsados o contrato social e alteraçōes posteriores, constatou-se a taxa de ... \% ao ano. ${ }^{4}$

- O perito, se for oinisso o contrato, observará o quanto decidido na Sentença ou Acórdão. 
O lucro operacional líquido médio histórico, em moeda constante, foi deduzido do lucro normal, surgindo um sobrevalor correspondente a $\$$.

Considerando que a sociedade avalianda tem prazo indeterminado de duração e permanece em atividade, adotoù-se a fórmula financeira da perpetuidade, tendo por numerador o "sobrevalor" no importe de \$................ e como denominador a taxa ... $\times \%$ correspondente ao custo do capital próprio.

Cabe observar que o lucro operacional líquido consigna apenas os resultados originários das operaçōes, excluídos, portanto, os resultados gerados pelos ativos não operacionais e os não operacionais e seus efeitos tributários, que, por sua própria natureza, resultam de transações eventuais ou não repetitivas.

As fórmulas adotadas nos cálculos de mensuração do valor da sociedade foram as que seguem:

- Valor da sociedade

VS $=P L v m+G$,

onde:

VS $=$ valor da sociedade

$\mathrm{PL}_{\mathrm{vm}}=$ patrimônio liquido a valores de mercado, na data-base

$\mathrm{G}=$ goodwill

- Cálculo do goodwill

$$
\mathbf{G}=\operatorname{LAN} / \mathbf{i} \text {, }
$$

onde:

$G \quad=$ goodwill

LAN = lucro acima do normal

i $=$ custo do capital próprio 
Com referência a eventuais contingências, a Perícia nada provisionou, pois a Requerente $X Y Z$, por meio de seu advogado, documento $n^{\circ} \ldots$, declarou inexistirem.

As provisões tributárias relativas aos ganhos de capital observados foram calculadas pela legislação vigente na data-base da apuração dos haveres e incluidas no balanço de determinaçāo.

\subsection{Balanço de determinação}

Feitos todos os ajustes avaliatórios retrocomentados, procedeu-se à elaboração do balanço de determinação, como demonstrado no anexo $n^{\circ}$..., que se apresenta, a seguir, de forma resumida. 


\section{BALANÇO DE DETERMINAÇÃO EM (data-base) \\ CONFORME LAUDO DO PERITO JUDICIAL DE ENGENHARIA}

ATIVO

CIRCULANTE

REALIZÁVEL A LONGO PRAZO

PERMANENTE

GOODWILL OU AVIAMENTO

TOTAL

PASSIVO

CIRCULANTE

EXIGIVEL A LONGO PRAZO

PATRIMÔNIO LIQUIDO

TOTAL

Como se observou, há controvérsia avaliatória dos imóveis suscitada pelo assistente técnico de engenharia indicado pelos requerentes, consignada no laudo parcialmente divergente que ofereceu.

Considerando os valores apresentados pelo assistente técnico indicado pelos requerentes, elaborou-se 0 anexo $n^{\circ} \ldots$... onde estão consignados os efeitos da referida avaliação parcialmente divergente.

Em face da divergência retro-relatada, com base no anexo $n^{0} \ldots .$. procedeu-se à elaboração de balanço de determinação, considerando referido efeito na massa patrimonial, o qual está materializado no anexo $n^{\circ}$.... e aqui resumidamente, a saber: 


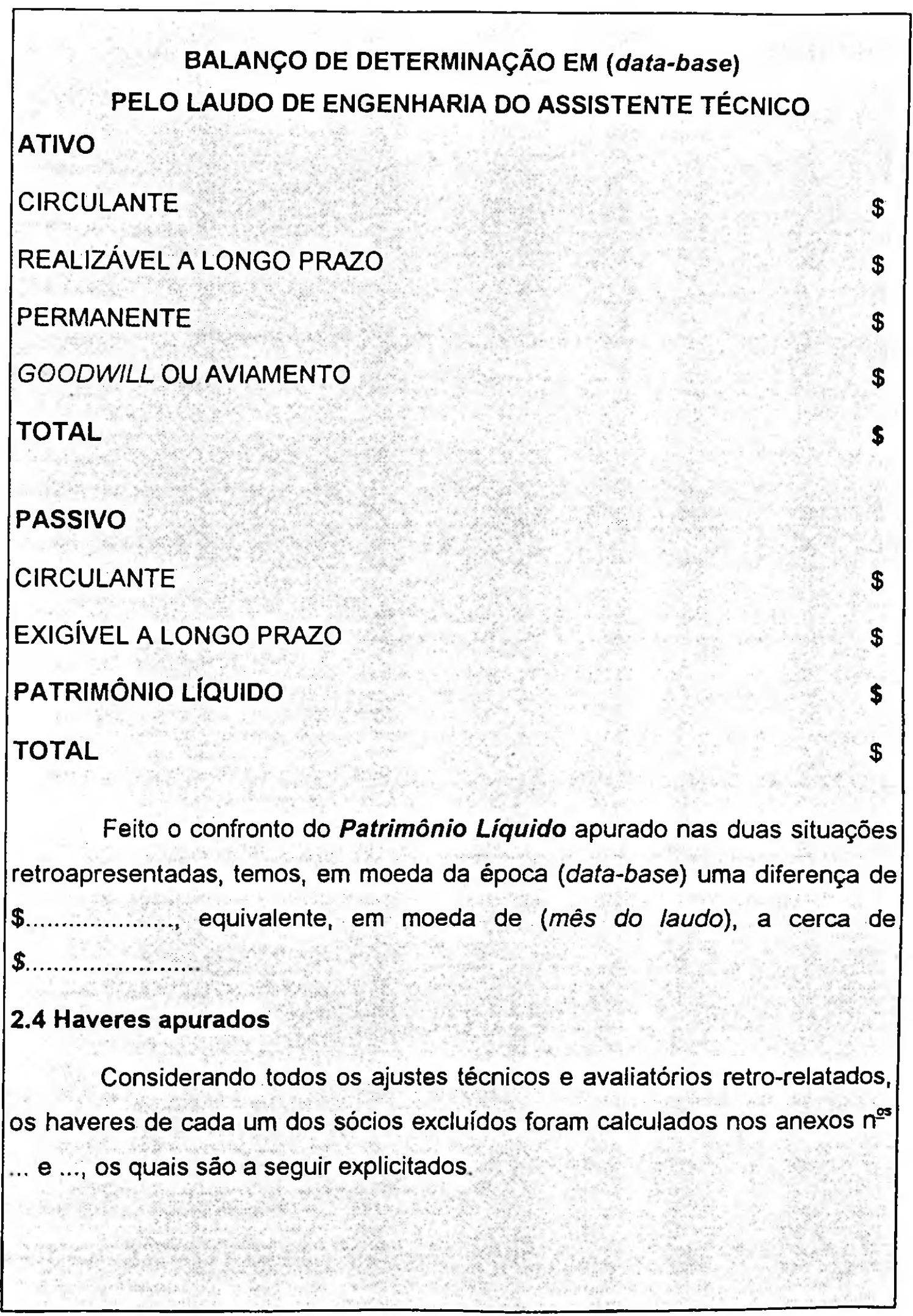


Para tal efeito, considerou-se a participação societária no capital social da sociedade avalianda constante da Alteração do contrato social de (data da alteração), assim:

sócios

Fulano 1

Beltrano 1

Fulano 2

Beltrano 2

TOTAIS

\section{COMPOSIÇĀO SOCIETÁRIA}

QUOTAS

$x x \cdot x x x$

$\mathbf{x x} \cdot \mathbf{x x x}$

$x x \cdot x x x$

$x \mathbf{x} . \mathbf{x x}$

$\mathbf{x x x} \cdot \mathbf{x x x}$
\% PARTICIPAÇĀO

$x \%$

$x \%$

$x \%$

$\mathbf{x} \%$

$100,00 \%$

Como se viu na sentença de fls., os sócios excluídos foram os Srs. Beltrano 1 e Beltrano 2, que são os requeridos na presente demanda.

Assim, os haveres dos sócios excluidos, como demonstrado nos anexos citados, tudo submetido ao alto discernimento do MM. Juizo, montam a:

\section{REQUERIDO BELTRANO 1 - AneXO $n^{\circ}$....}

- Se considerado o Laudo de Engenharia do Sr. Perito Judicial

Em moeda da época (data-base)

$\$$.

equivalente em moeda de (data do laudo) a

$\$$. (por extenso)

- Se considerado o Laudo do Sr. Assistente Técnico

Em moeda da época (data-base)

$\$$

equivalente em moeda de (data do laudo) a

$\$$ (por extenso) 


\section{REQUERIDO Beltrano 2 - Anexo $n^{\circ}$....}

- Se considerado o Laudo de Engenharia do Sr. Perito Judicial

Em moeda da época (data-base)

$\$$

equivalente em moeda de (data do laudo) a

$\$$.

(por extenso)

- Se considerado o Laudo do Sr. Assistente Técnico

Em moeda da época (data-base)

$\$$.

equivalente em moeda de (data do laudo) a

$\$$ (por extenso)

Posto isto, a seguir são oferecidas respostas aos quesitos formulados pelas Partes, pela ordem de juntada. 


\section{IV - DO TÓPICO RELATIVO ÀS RESPOSTAS AOS QUESITOS}

É possivel o perito em contabilidade deparar com quesitos em processo judicial que envolva apuração de haveres. Trata-se das perguntas de natureza técnica formuladas pelo magistrado ou pelas partes.

As respostas são, por óbvio, orientadas pela própria indagação formulada; entretanto, muitas das perguntas poderão ser respondidas, reportando-se o perito a determinados conteúdos do tópico anterior, evitando repetições desnecessárias.

Quando se deparar com quesitos de conteúdo semelhante, responderá àquele primeiro formulado e, em seguida, ao responder ao outro, reportar-se-á ao já respondido.

Cuidado especial deve ter o profissional quanto a eventuais quesitos indeferidos cuja resposta será prejudicada exatamente por ter sido indeferido.

Quesitos formulados sobre matéria fora do objeto do que se debate nos autos do processo têm, por óbvio, sua resposta prejudicada, mesmo porque a prova pericial contábil é sempre especifica, limitada, adstrita.

É da boa técnica pericial transcrever o texto do quesito tal qual foi formulado, inclusive com eventual erro de ortografia ${ }^{5}$ e, em seguida, oferecer $o$ texto da resposta.

A seguir, ilustração de quesitos formulados e respectivas respostas.

5 Não pode o perito modificar o texto proposto, o que poderá ensejar critica de quem formulou, no sentido de que possa ter alterado seu significado. 


\section{DAS RESPOSTAS AOS QUESITOS}

\subsection{Dos Requerentes - FIs.....}

1. Considerando-se as demonstraçōes financeiras do mês anterior à propositura da ação e os resultados contábeis subseqüentes até a data do laudo, assim como aplicando-se a taxa de desconto efetiva produzida da própria empresa, qual é seu valor?

\section{RESPOSTA:}

O Patrimônio Líquido da Requerente $X Y Z$, conforme balanço de determinação, no dia (data do evento), data-base da apuração dos haveres dos sócios excluídos, observados todos os ajustes técnicos e avaliatórios relatados na seção anterior deste laudo, corresponde a:

- Se considerado o Laudo de Engenharia do Sr. Perito Judicial

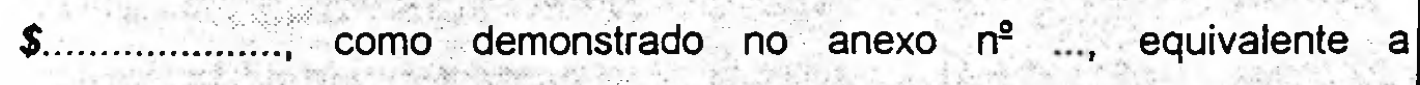
\$.................. em moeda da época do laudo.

- Se considerado o Laudo do Sr. Assistente Técnico

\$................... como demonstrado no anexo $n^{0} \ldots$ equivalente a \$.................... em moeda da época do laudo. 
3.2 Dos Requeridos - Fls. ....

1. Pede-se ao Sr. Perito Judicial verificar se os livros e assentamentos contábeis da sociedade em discussão - XYZ INDÚSTRIA DE PRODUTOS TÉCNICOS LTDA - estão revestidos de todas as suas caracteristicas intrinsecas e extrinsecas, de modo a representar com propriedade todas as suas respectivas operaçōes sociais.

\section{RESPOSTA:}

Os livros e os documentos contábeis da época da exclusāo dos Requeridos, exibidos e compulsados pela Perícia, estavam revestidos das formalidades legais extrinsecas e intrinsecas, sendo, portanto, merecedores de fé em juizo.

Os livros compulsados foram aqueles especificados no anexo $n^{\circ}$... 
3.2 Dos Requeridos - FIs. ....

2. Qual a participaçāo social dos Réus, na empresa periciada?

\section{RESPOSTA:}

Compulsada a Alteração do Contrato Social de (data da alteração), constatou a Pericia que os sócios excluidos tinham a seguinte participaçāo no capital social:

Beltrano 1 $x \%$

Beltrano 2 $y \%$ 
3.2 Dos Requeridos - Fls. ....

3. Contabilmente, qual 0 valor do patrimônio líquido da sociedade $X Y Z$ Indústria de Produtos Ltda., na data do desligamento dos Réus?

\section{RESPOSTA:}

Como demonstrado no anexo $n^{\circ} \ldots$, o valor do patrimônio líquido contábil, observados todos os ajustes técnicos, no dia (data do evento), corresponde a $\$$. 
3.2 Dos Requeridos - Fls. ....

4. Informe o Sr. Perito, discriminadamente, os bens que compöem o Ativo Permanente da Sociedade periciada, nominando seus valores contábeis, e também reais e de mercado, para a época da apuração dos haveres dos Réus.

RESPOSTA:

A Perícia pede vênia para se reportar aos anexos $n^{0 s} \ldots, \ldots, \ldots, \ldots, \ldots, \ldots$ e $\ldots$ e ao tópico anterior onde o aqui requerido foi especificado. 
3.2 Dos Requeridos - Fls. ....

5. Quantifique o Sr. Perito o valor do estabelecimento Autor, na data do desligamento dos Réus, nele compreendidos todos os valores materiais e imateriais que formam o conjunto das atividades do estabelecimento, com valores reais e de mercado.

RESPOSTA:

A Pericia pede vênia para se reportar à resposta oferecida ao quesito de $n^{\circ}$....., da série dos Requerentes. 


\subsection{Dos Requeridos - Fls. ....}

6. Com base na apuração do quesito anterior, qual o valor do quinhão social dos Réus, à época de seus desligamentos?

\section{RESPOSTA:}

Como demonstrado na seção anterior do Laudo, os valores dos haveres apurados, para cada um dos sócios excluidos, são os que seguem:

$$
\text { REQUERIDO BELTRANO } 1 \text { - AneXo } n^{\circ} \text {... }
$$

- Pelo Laudo de Engenharia do Sr. Perito Judicial

Em moeda da época (data-base)

$\$$.

equivalente em moeda de (data do laudo) a

$\$$. (por extenso)

- Pelo Laudo de Engenharia do Sr. Assistente Técnico

Em moeda da época (data-base)

$\$$

equivalente em moeda de (data do laudo) a

$\$$.

(por extenso) 


\section{REQUERIDO BELTRANO 2 - Anexo $\mathrm{n}^{\circ}$...}

- Pelo Laudo de Engenharia do Sr. Perito Judicial

Em moeda da época (data-base)

$\$$.

equivalente em moeda de (data do laudo) a

$\$$.

(por extenso)

- Pelo Laudo de Engenharia do Sr. Assistente Técnico

Em moeda da época (data-base)

$\$$.

equivalente em moeda de (data do laudo) a

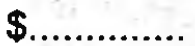
(por extenso) 


\section{V - DO TÓPICO RELATIVO ÀS CONSIDERAÇŌES FINAIS}

Terminadas as respostas aos quesitos porventura formulados, é chegado o momento de resumir e concluir a matéria técnica submetida ao perito em contabilidade.

O expert desenvolve exposição resumida da matéria fática observada, suas conclusões e, circunstancialmente, comentários técnicos de questōes surgidas no decorrer do trabalho pericial relacionadas com o objeto da perícia e dentro de seus limites que não tenham sido objeto de quesitos.

A seguir, ilustração deste tópico. 


\section{DAS CONSIDERAC̣ÕES FINAIS}

Em resumo a tudo o que foi oferecido, a Perícia entende ser oportuno alguns comentários técnicos finais. Assim, temos:

a. Pelo que se observou ao longo do desenvolvimento dos trabalhos periciais, a Requerente XYZ é uma sociedade bem administrada e sólida, com performance destacada e crescente no mercado em que atua.

b. Os dados colhidos e os cálculos levados a termo pela Perícia evidenciaram o valor da sociedade avalianda, na data-base, no seguinte patamar:

- Se considerado o Laudo de Engenharia do Sr. Perito Judicial

$\$$..................., como demonstrado no anexo $n^{\circ} \ldots$, equivalente a cerca de $\$$.................... em moeda da época do laudo.

- Se considerado o Laudo de Engenharia do Sr. Assistente técnico

$\$$. como demonstrado no anexo $\mathrm{n}^{\circ} \ldots$, equivalente a cerca de

$\$$. em moeda da época do laudo.

c. A controvérsia que envolve os laudos periciais de engenharia a ser enfrentada pelo Magistrado está situada na diferença de valores quanto à avaliação do acervo imobiliário pertencente à sociedade. A divergência de valores entre o laudo pericial do perito engenheiro e aquele oferecido pelo assistente técnico dos requerentes provoca uma diferença para ......., no valor da sociedade, em cerca de $\$$................... a preços de (data do laudo).

d. Os haveres apurados a favor dos sócios excluidos, considerando as duas alternativas quanto ao valor dos imóveis, tudo submetido ao alto discernimento do MM. Juizo, correspondem aos seguintes valores: 


\section{REQUERIDO BELTRANO 1 - Anexo $n^{\circ}$....}

- Pelo Laudo de Engenharia do Sr. Perito Judicial

Em moeda da época (data-base)

$\$$

equivalente em moeda de (data do laudo) a

$\$$ (por extenso)

- Pelo Laudo de Engenharia do Sr. Assistente Técnico

Em moeda da época (data-base)

$\$$

equivalente em moeda de (data do laudo) a

$\$$. (por extenso)

\section{REQUERIDO BELTRANO 2 - Anexo $\mathrm{n}^{\circ}$....}

- Pelo Laudo de Engenharia do Sr. Perito Judicial

Em moeda da época (data-base)

$\$$.

equivalente em moeda de (data do laudo) a

$\$$. (por extenso)

- Pelo Laudo de Engenharia do Sr. Assistente Técnico Em moeda da época (data-base)

$\$$

equivalente em moeda de (data do laudo) a

$\$$ (por extenso)

É opiniāo da Perícia que o MM. Juizo encontrará no Laudo e respectivos anexos e documentos elementos capazes de oferecer certeza à matéria fática objeto da lide. 


\section{VI - DO TÓPICO RELATIVO AO ENCERRAMENTO}

Este tópico do laudo pericial contábil de apuração de haveres, como o próprio já indica, corresponde ao encerramento do trabalho pericial, no qual o perito dá por encerrado o laudo, indicando a quantidade de folhas, anexos e documentos que o compõem.

É aqui que o perito assume a autoria do trabalho pericial, datando e assinando o laudo pericial contábil de apuração de haveres.

Em seguida, são juntados os anexos e documentos, aqueles elaborados pelo perito, estes colhidos quando das diligências, enfim, todos aqueles elementos de suporte aos procedimentos técnicos desenvolvidos e às respostas aos quesitos.

A seguir, a respectiva ilustração. 


\section{DO ENCERRAMENTO}

Nada mais havendo a responder ou a considerar, encerra-se o presente Laudo Pericial Contábil, processado em .... (por extenso) folhas, .... (por extenso) anexos e .... (por extenso) documentos, que englobam o resultado dos trabalhos desenvolvidos, tudo para atender à Apuração de Haveres determinada pelo MM. Juizo e às indagações formuladas pelas $P$ artes.

Esta última folha vai datada e assinada, enquanto as demais, os anexos e os documentos vão rubricados.

(Nome da cidade), .... de de

(Nome do Perito)

Perito Judicial 


\section{VII - ALGUNS COMENTÁRIOS ADICIONAIS}

$O$ modelo e o roteiro que acabam de ser oferecidos são plenamente adequados ao trabalho desenvolvido pelo perito em contabilidade, quando nomeado em processo judicial que requeira apuração de haveres.

Quando estiver na funçăo de assistente técnico indicado pela parte tem o dever funcional de oferecer parecer pericial contábil sobre o conteúdo do laudo apresentado pelo perito judicial.

A título indicativo, o conteúdo do parecer pericial contábil pode ser ordenado assim:

\section{Do resumo do laudo oficial}

Neste tópico, o assistente técnico apresenta, em resumo, os aspectos fundamentais contidos no laudo oficial oferecido pelo perito judicial.

\section{Dos comentários ao laudo oficial}

O assistente técnico oferece seus comentários sobre a peça técnica, realçando os aspectos positivos em favor de quem o indicou e minimizando eventuais aspectos negativos.

É também o momento de oferecer comentários concordantes, criticos, divergentes, apontando erros ou equivocos observados, procedimentos inadequados e inconsistências técnicas à luz da boa técnica contábil e da jurisprudência.

A crítica deve ser rigorosa, tanto no plano técnico quanto no teórico, buscando preservar a ética que deve permear sua elaboração sem perder a elegância, ou seja, o que se critica é o resultado do trabalho consubstanciado no laudo, não quem o elaborou. 


\section{Do parecer pericial}

O assistente técnico oferece sua opiniāo sobre o conteúdo do laudo pericial contábil de apuração de haveres, concordando ou discordando, tudo devidamente justificado.

Nos mesmos moldes que no laudo, o parecer pericial contábil conterá endereçamento, indice e encerramento; é, portanto, desnecessário discorrer, novamente, sobre tais itens.

Pode também instruir seu parecer com anexos e documentos que entender necessários a justificar sua opinião. 


\section{BIBLIOGRAFIA}

AAKER, David A. Marcas: brand equity gerenciando o valor da marca. São Paulo : Negócio, 1998.

ABRÃO, Nelson. Sociedade por quotas de responsabilidade limitada. 2. ed. São Paulo : Saraiva, 1980.

ALBERTO, Valder Luiz Palombo. Perícia contábil. São Paulo : Atlas, 1996.

ALLA, Jean. L'évaluation de l'entreprise: de la théorie à la pratique. Paris : Editions Cujas, 1978.

AUTUORI, Luiz. Fundo de comércio. 3. ed. Rio de Janeiro : Forense, 1969.

BERNHOEFT, Renato, CASTANHEIRA, Joaquim. Manual de sobrevivência para sócios e herdeiros. Sāo Paulo : Nobel, 1995.

BESSIERE, Véronique, COISPEAU, Olivier. L'évaluation des entreprises. Ontário, Canadá : Séfi, 1992.

BLACKMAN, I. I. The valuation of privately-held bussiness: state of art techniques for buyers, sellers and advisers. Chicago : Probus, 1986.

BRASIL. Código comercial. 9. ed. São Paulo : Saraiva, 1951.

BRASIL. Código de processo civil. Org. dos textos, notas remissivas e indices por Juarez de Oliveira. 11. ed. São Paulo: Saraiva, 1996.

BRASIL. Consolidação das leis do trabalho. Org. Juarez de Oliveira. 18. ed. Sāo Paulo: Saraiva, 1994.

BRASIL. Lei de falências. Org. dos textos, notas remissivas e indices por Juarez de Oliveira. 12. ed. São Paulo : Saraiva, 1996.

BRASIL. Lei das sociedades por ações. 6. ed. São Paulo : Atlas, 1978. 
BULGARELLI, Waldirio, Fusões, incorporações e cisões de sociedades. 2. ed. São Paulo: Atlas, 1996.

. O novo direito empresarial. Rio de Janeiro : Renovar, 1999.

. Sociedades comerciais: sociedades civis e sociedades cooperativas: empresas e estabelecimento comercial. 6. ed. São Paulo : Atlas, 1996.

et al. Reforma da lei das sociedades por ações. São Paulo : Pioneira, 1998.

COELHO, Fábio Ulhoa. Curso de direito comercial. 2. ed. São Paulo : Saraiva, 1999. v. 1.

: Curso de direito comercial. São Paulo: Saraiva, 1999. v. 2.

CONSELHO REGIONAL DE CONTABILIDADE DO ESTADO DE SÃO PAULO. Os principios fundamentais de contabilidade, as normas brasileiras de contabilidade e o código de ética profissional do contabilista. 26. ed. São Paulo : CRC-SP, 1999.

COPELAND, Thomas E., WESTON, J. Fred. Financial theory and corporate policy. 3. ed. New York: : Addison-Wesley, 1992.

COPELAND, TOm, KOLLER, T., MURRIN, J. Valuation: measuring and managing the value of companies. 2. ed. New York: John Wiley, 1994.

CORDONIZ, L. M. Avaliação de empresas em contexto inflacionário com base no fluxo de caixa descontado. Dissertação (Mestrado). São Paulo : FGV-SP, 1988.

CORNELL, Bradford. Corporate valuation: tools for effective appraisal and decision making. New York: Richard D. Irwin, 1993.

CORTESE, Antonio Carlos et al. Patrimônio e sucessão: como garantir os herdeiros e os negócios. São Paulo: Maltese, 1993.

COSTA, Magnus Amaral da. Contribuição à teoria contábil do lucro: classificaçāo dos lucros e a técnica de ajustamento pelo valor atual dos benefícios futuros. Enfoque - Reflexão Contábil, Revista de Contabilidade da Universidade Estadual de Maringá, Paraná, v. 4, ํ․ 4, 1992. 
DAMODARAN, Aswath. Avaliação de investimentos: ferramentas e técnicas para a determinação do valor de qualquer ativo. Rio de Janeiro: Qualitymark, 1997.

EDWARDS, Edgar O., BELL, Philip W. The theory and measurement of business income. Los Angeles : University of California Press, 1964.

EHRBAR, Al. EVA: valor econômico agregado: a verdadeira chave para a criação de riqueza. Rio de Janeiro : Qualitymark, 1999.

EID JUNIOR, William. A redução do risco das carteiras de investimento através da diversificação aleatória: estudo de caso na Bovespa. Dissertação (Mestrado). São Paulo : EAESP-FGV, 1991.

ESTRELLA, Hernani. Apuração dos haveres de sócio. Rio de Janeiro : José Konfino, 1960.

. Curso de direito comercial. Rio de Janeiro : José Konfino, 1973.

FABRETTI, Láudio Camargo. Código tributário comentado. São Paulo : Saraiva, 1998.

FALCINI, Primo. Avaliação econômica de empresas: técnica e prática. São Paulo : Atlas, 1992.

FERNANDES, Francisco Carlos. Goodwill. São Paulo : FEA-USP, 1995.

FISHER, Irving. A teoria do juro: determinada pela impaciência por gastar renda e pela oportunidade de investi-la. São Paulo: Abril Cultural, 1984.

FRANCIS, Jack Clark. Investments: analysis and management. 4. ed. New York: McGraw-Hill, 1986.

FREZATTI, Fábio. Contribuição para o estudo da complementaridade do lucro e do fluxo de caixa na gestão de negócios no ambiente empresarial brasileiro. Tese (Doutoramento). São Paulo : FEA-USP, 1996.

_. Gestão do fluxo de caixa diário: como dispor de um instrumento fundamental para o gerenciamento do negócio. São Paulo: Atlas, 1999. 
- Valor da empresa: avaliação de ativos pela abordagem do resultado econômico residual. Caderno de Estudos - Fipecafi. São Paulo, n 19, set./dez. 1998.

HARRINGTON. D. R. Modern portfolio theory, the capital asset pricing model and arbitrage pricing theory: a user's guide. 2. ed. Englewood Cliffs : Prentice Hall, 1987.

HENDRIKSEN, Eldon S. Accounting theory. 3. ed. Homewood, llinois : Richard D. Irwin, 1977.

— VAN BREDA, Michael F. Accounting theory. 5. ed. Homewood, llinois : Richard D. Irwin, 1992.

HERMANN JR., Frederico. Contabilidade superior: teoria econômica da contabilidade. 8. ed. São Paulo : Atlas, 1970.

IUDíCıBUS, Sérgio de. Análise de balanços. 5. ed. São Paulo : Atlas, 1988.

_. MARION, José Carlos. Introdução à teoria da contabilidade: para o nivel de graduação. São Paulo: Atlas, 1999.

_..Teoria da contabilidade. 4. ed. São Paulo : Atlas, 1995.

JAEDICKE, Robert Keith, SPROUSE, Robert T. Fluxos contábeis: rendas, fundos e capital. São Paulo : Atlas, 1972.

JOHNSON, H. Thomas, KAPLAN, Robert S. Relevance lost: the rise and fall of management accounting. Boston: Harvard Business School Press, 1991.

KALECKI, Michal. Teoria da dinâmica econômica: ensaio sobre as mudanças cíclicas e a longo prazo da economia capitalista. São Paulo : Abril Cultural, 1983.

KANITZ, Stephen Charles. Como prever falências. Säo Paulo : McGraw-Hill do Brasil, 1978.

KASSAI, José Roberto et al. Retorno de investimento: uma abordagem matemática e contábil do lucro empresarial. São Paulo: Atlas, 1999. 
KEYNES, John Maynard. A teoria geral do emprego, do juro e da moeda: inflação e deflação. São Paulo : Abril Cultural, 1983.

KINGSTON, J.P.R., MCQUILLAN, P. E. Valuations of business: a pratical guide. 3 ed. Don mills : Cch Canadian, 1986.

LEITE, Helio de Paula. Introdução à administração financeira. São Paulo : Atlas, 1989.

LODI, João Bosco. A empresa familiar. 4. ed. Sāo Paulo : Pioneira, 1993. . Sucessão e conflito na empresa familiar. São Paulo : Pioneira, 1987.

LOPES DE SÁ, Antonio. Perícia contábil. 3. ed. Sāo Paulo : Atlas, 1997.

LORIE, James H., HAMILTON, Mary T. The stock market: theories and evidence. Homewood, Illinois : Richard D. Irwin, 1973.

L'UNION EUROPÉENNE DES EXPERTS-COMPTABLES ÉCONOMIQUES E FINANCIERS. L'évaluation des entreprises et parts d'entreprises: règles formulées par la comission spéciale U.E.C. Paris : Dunod, 1961.

MARTINS, Eliseu. Contribuição à avaliação do ativo intangivel. Tese (Doutoramento). São Paulo : FEA-USP, 1972.

MARTINS, Fran. Curso de direito comercial: empresa comercial, empresários individuais, microempresas, sociedades comerciais, fundo de comércio. 23. ed. Rio de Janeiro : Forense, 1999.

MONOBE, Massanori. Contribuição à mensuração e contabilização do goodwill não adquirido. Tese (Doutoramento). São Paulo : FEA-USP, 1986.

MOST, Kenneth S. Accounting theory. Columbus : Grid, 1977.

NEIVA, Raimundo Alelaf. Valor de mercado da empresa. São Paulo : Atlas, 1992.

ORNELAS, Martinho Mauricio Gomes de. Avaliação de empresas em processos judiciais: alguns limites e dificuldades. Anais do XV Congresso Brasileiro de Contabilidade. Fortaleza, out.1996.

Perícia contábil. 2. ed. São Paulo: Atlas, 1995. 
__. Perícia contábil em falência e concordatas. Anais do XIV Congresso Brasileiro de Contabilidade. Salvador, out.1992.

_. Teoria dos portfolios. Sāo Paulo : FEA-USP, 1995.

PEREIRA, Guilherme Döring Cunha. Alienação do poder de controle acionário. São Paulo : Saraiva, 1995.

PORTER, Michael E. Vantagem competitiva: criando e sustentando um desempenho superior. Rio de Janeiro : Campus, 1992.

PRISCO PARAiSO, Anna Luiza Gayoso e Almendra. O direito de retirada na sociedade anônima. Rio de Janeiro : Forense Universitária, 1985.

QUILICI, Frediano. Leituras em administração contábil e financeira. Rio de Janeiro : FGV, 1974.

REQUIĀO, Rubens. Curso de direito comercial. 22. ed. São Paulo: Saraiva, 1995.

RICARDO, David. Principios de economia política e tributação. São Paulo : Abril Cultural, 1982.

ROBINSON, Joan V. Ensaios sobre a teoria do crescimento econômico. São Paulo: Abril Cultural, 1983.

SÁ, Geraldo Tosta de. Investimentos no mercado de capitais. Rio de Janeiro: Ao Livro Técnico/Bolsa de Valores, 1979.

SANT'ANNA, Rubens. Direito societário: estudos sobre a sociedade por quotas de responsabilidade limitada e a sociedade anônima. Porto Alegre : Livraria do Advogado, 1988.

SANVICENTE, Antônio Zoratto. Administração financeira. 3. ed. São Paulo : Atlas, 1997.

SECURATO, José Roberto. Decisões financeiras em condições de risco. Sāo Paulo : Atlas, 1993.

SEVERINO, Antônio Joaquim. Metodologia do trabalho científico. 21. ed. Sāo Paulo : Cortez, 2000. 
SHARPE, William F., ALEXANDER, Gordon J. Investments. 4. ed. Englewood Cliffs : Prentice Hall, 1990.

SINGER, Paul. Curso de introdução à economia política. 2. ed. Rio de Janeiro : Forense Universitária, 1978.

SLYWOTZKY, Adrian J., MORRISON, David J. A estratégia focada no lucro - profit zone: desvendando os segredos da lucratividade. Rio de Janeiro : Campus, 1998.

SOLOMON, Ezra. Teoria da administração financeira. 3. ed. Rio de Janeiro : Zahar, 1977.

SOUZA, Alceu, CLEMENTE, Ademir. Decisões financeiras e análise de investimentos. São Paulo: Atlas, 1995.

SWEEZY. Paul M. Teoria do desenvolvimento capitalista: princípios de economia política marxista. 4. ed. Rio de Janeiro : Zahar, 1976.

VENTURA, Raúl. Dissolução e liquidação de sociedades: comentários ao código das sociedades comerciais (portuguesas). Coimbra : Almedina, 1993.

WALD, Arnoldo. Direito das sucessões. 11. ed. São Paulo : Revista dos Tribunais, 1997. 